\title{
A KÖZEPES MÉRETARÁNYÚ TÁJÖKOLÓGIAI EGYSÉGEK HATÁRAINAK MATEMATIKAI-STATISZTIKAI ALAPÚ VIZSGÁLATA
}

Doktori (Ph. D.) értekezés

Bata Teodóra

Témavezető:

Prof. Dr. Mezősi Gábor

Földtudományok Doktori Iskola

Természeti Földrajzi és Geoinformatikai Tanszék

Szegedi Tudományegyetem, Természettudományi és Informatikai Kar 


\section{Tartalomjegyzék}

1. Bevezetés, célkitüzések ..................................................................................................3

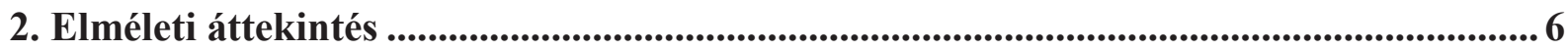

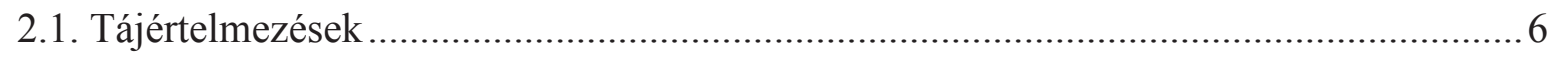

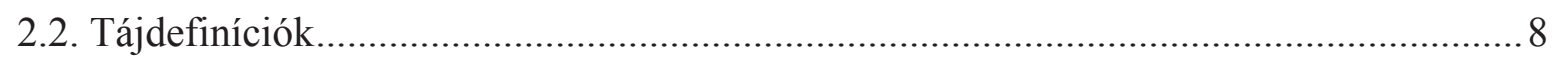

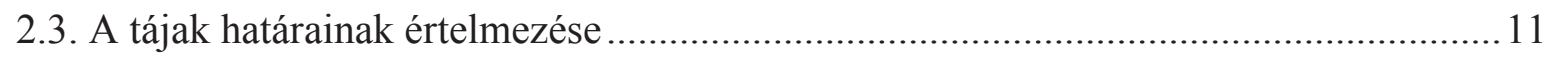

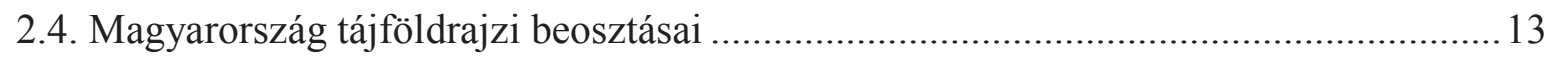

2.5. A tradicionálisan definiált tájfelosztás bírálatai, módosítási javaslatai .......................20

3. Alkalmazott kutatási módszerek ............................................................................ 25

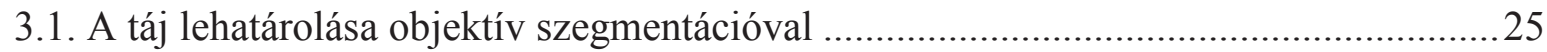

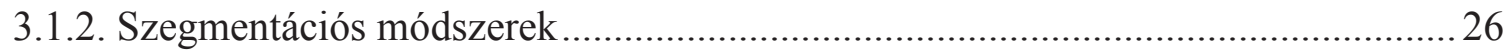

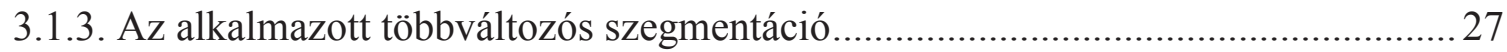

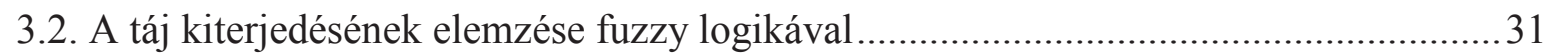

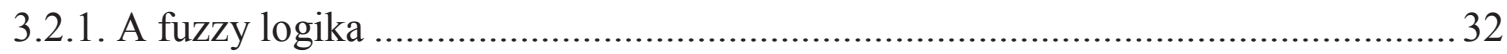

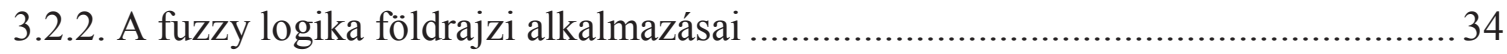

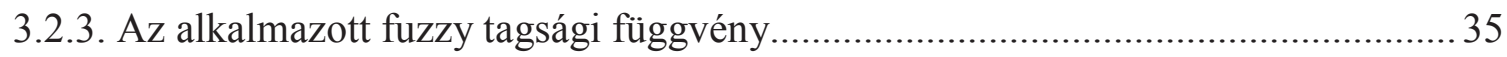

3.3. A tájak- és határaik érzékenységének vizsgálata (a mesterséges gátak okozta

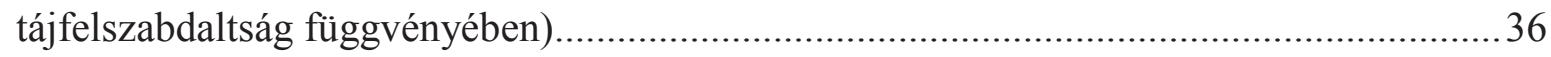

4.Vizsgált terület, adatok ................................................................................................................. 42

5. Eredmények és következtetések ...............................................................................49

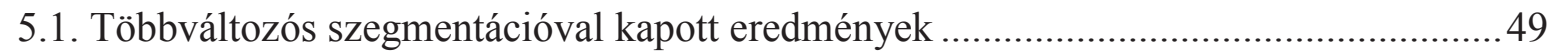

5.2. A fuzzy logikával történő megközelítés eredményei ..............................................52

5.3. Validáció: összehasonlító elemzések a többváltozós szegmentáció - és a fuzzy

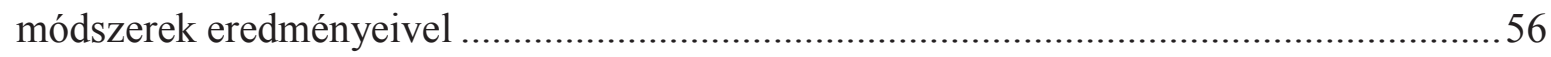

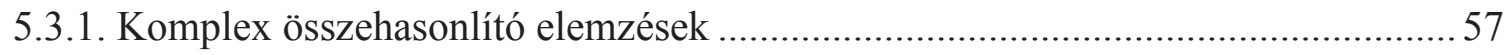

5.3.2. Összehasonlító elemzés a fuzzy logika alkalmazásával ....................................59

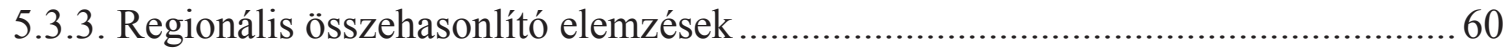


5.4. A mesterséges gátak okozta tájfelszabdaltság változásának eredményei 63

5.4.1. A mesterséges gátak változásai 1990 és 2011 között ........................................... 64

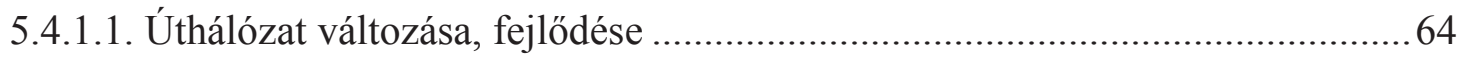

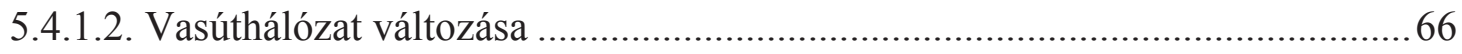

5.4.1.3. Települések belterületének változása ...........................................................66

5.4.2. A tradicionálisan definiált kistájak felszabdaltságának változása a vizsgált

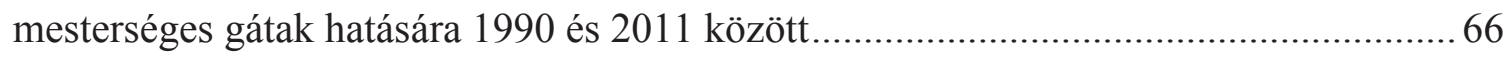

5.4.3. A tradicionálisan definiált kistájak felszabdaltságának várható változása a vizsgált mesterséges gátak hatására 2011 és 2027 között ............................................ 71

5.4.4. A mesterséges gátakkal felszabdalt kistájak érzékenysége, stabilitása .................. 74

5.4.5. A közepes méretarányú tájökológiai egységek határainak érzékenysége .............. 77

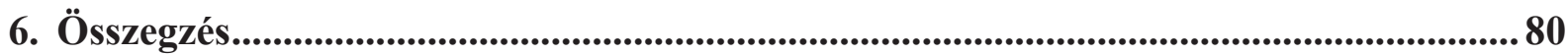

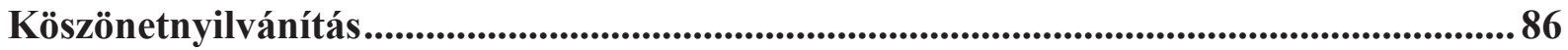

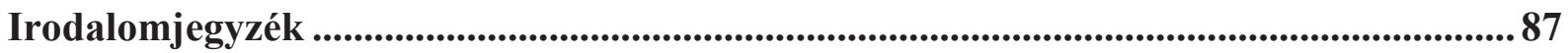

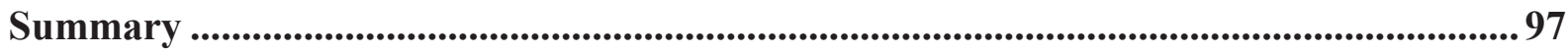

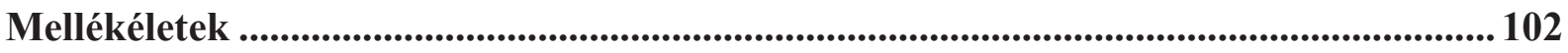




\section{Bevezetés, célkitüzések}

A tájak határainak kérdéskörével már a 1900-as évek elejétől foglalkoznak Magyarországon. A tájak értelmezésére számos megközelítés ismert, de a gyakorlati szempontból, a tájakkal kapcsolatos tervezési, fejlesztési-, működési kérdések miatt fontos a tájak - megadandó hibahatárok mellett - pontos területi meghatározása. Elméleti szempontból a táj a földrajztudomány egyik térbeli alapkategóriája, ami ugyancsak indokolja az egzaktabb lehatárolást, hiszen nincs földrajzi áttekintés, tájak értékelése, elemzése a tájak területi (hierarchikusan felépülö) rendszertana nélkül Prinz (1936).

A táj sajátos arculatát a tájalkotó tényezők együttese adja meg, táj integrált rendszer. A tájak elkülönítése nehéz feladat, főként, ha a cél nem azok pontos, vonallal történő lehatárolása. A tájlehatárolást számos tényező nehezíti, ilyen például az egyes tájalkotó tényezők, mint a botanikai, a talajtani, vagy a domborzati tényezők határai kisebb - nagyobb mértékben eltérnek egymástól, és gyakran még önmagukat tekintve sem különíthetőek el merev vonalakkal, például a botanikai egységek határai. Mindezek mellett a lehatárolás során fontos szempont egy olyan megoldás választása, ahol a természeti és társadalmi tényezőket, ill. azok a hatásait megfelelő módon integrálni lehet.

Az integrálási igény figyelembevétele mellett egyik kutatási célom volt egy olyan objektív közepes méretarányú tájökológiai egységlehatárolás ( kistáj szintű) elkészítése, mely a mezoléptékű regionális kutatásokhoz megfelelő alapot nyújtana az egységek határairól. A lehatároláshoz egy objektív többváltozós szegmentációt alkalmaztam. Eredményeimet a már létező tájfelosztásokkal és egyes lehatárolási javaslatokkal validáltam (Marosi - Somogyi szerk. 1990, Ladányi 2010, Deák 2010, Molnár et al. 2008, Mücher et al. 2010).

A határok értelmezésének egy másik megközelítése alapján viszont a tájökológiai egységek határait nem tekinthetjük merev határként. A botanikai, talajtani, vagy domborzati mintázatok jelentősen eltérhetnek egymástól, nem ugyanazt a felszíndarabot fedik le, e mellett az egyes tájalkotó tényezők időben is folyamatosan, eltérő sebességgel változnak, így még önmagukban sem alkotnak merev határt. Ezért a tájak, mint integrált egységek határainak megvonása módszertanilag nem egyszerű feladat, nem húzhatóak meg vonallal. Ezen megállapítások alapján egyik kutatási célom volt a határok fuzzy, „lágy halmazok” módszerével történő értelmezése.

Az antropogén beavatkozások a természeti tájalkotó tényezők által kialakított táj arculatát pillanatok alatt képesek felülírni. A táji lehatárolások mellett fontos kérdés a tájökológiai egységek ökológiai stabilitásának mérése az egységek határának érzékenységvizsgálata. 
Így további kutatási célomnak tekintettem a mesterséges (antropogén) gátak okozta tájfelszabdaltság vizsgálatát, hogy képet kaphassak, hogy a tájak, földrajzi határok mennyire, illetve milyen formában érzékenyek pl. a különböző antropogén hatásokra. Kutatásom a tájökológiai egységeken ( kistáj) belüli mesterségek gátak okozta felszabdaltság kérdéseire összpontosított, annak matematikai-statisztikai elemzésü hátterével, különböző tájmetriai mutatók kiszámításával kívánta objektíven mérni a felszabdaltságot, illetve annak változását térben és időben egyaránt ${ }^{1}$.

\footnotetext{
${ }^{1}$ A következő oldalon megtekinthető a kutatás folyamatának sematikus váza
} 


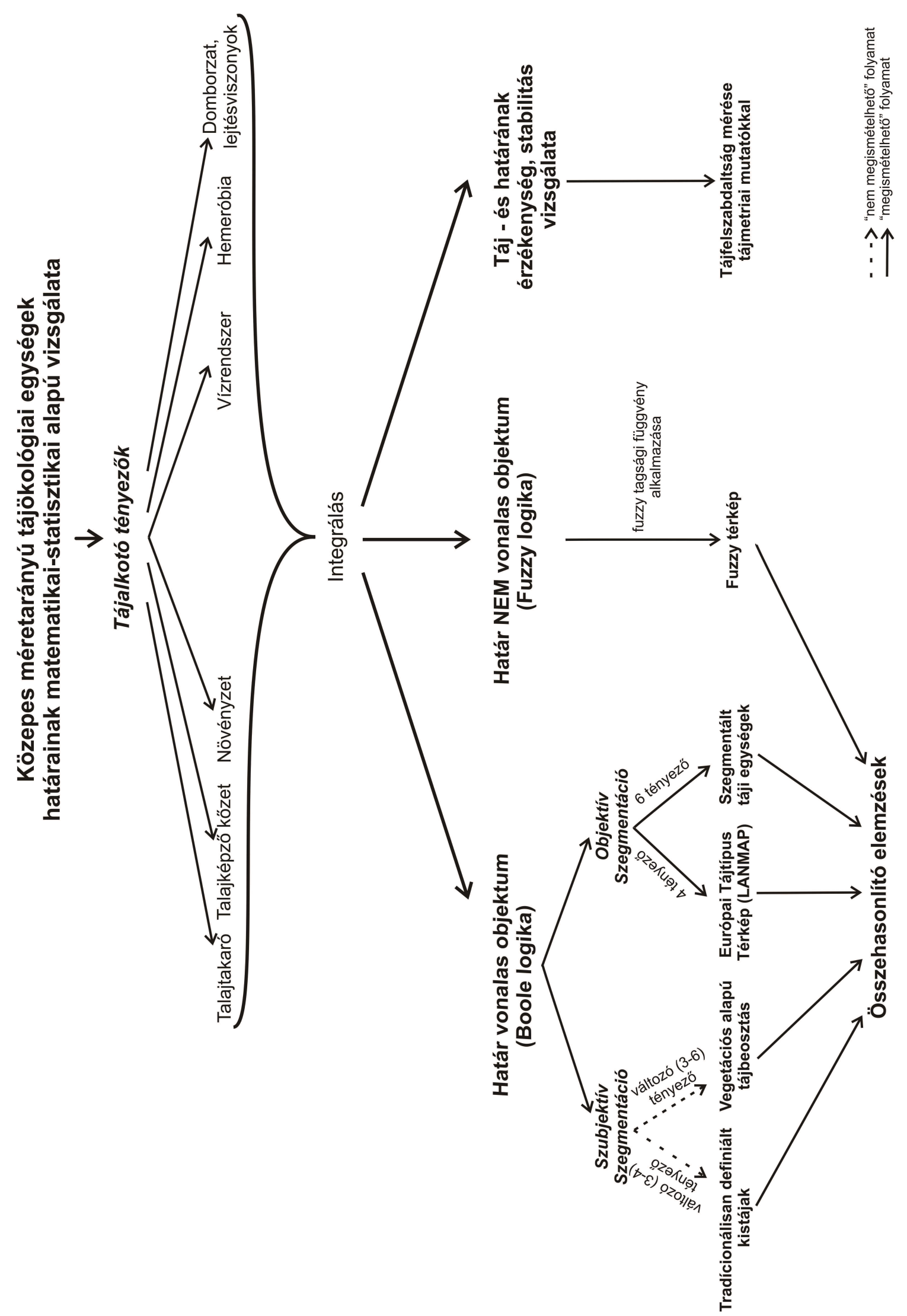




\section{EIméleti áttekintés}

A táj értelmezésére számos megközelítési mód ismert, mivel nincs egy általánosan elfogadott definíció a tájra. Egy adott tájértelmezés magával vonja, hogy kialakul egy egyedi definíció a tájra. Ennek megfelelően más - más definícióhoz más tájlehatárolás készíthető el.

Doktori dolgozatomban elsőként szeretném bemutatni röviden a fontosabb tájértelmezéseket és az ezek alapján alkotott tájdefiníciókat, illetve a különbözö magyarországi már térképeken is megjelenített tájlehatárolásokat.

\subsection{Tájértelmezések}

A táj a természetföldrajz leggyakrabban használt fogalma, kutatási területegysége. A tájat a saját nézőpontjából nagyon sok, e fogalmat alkalmazó tudományág használja. A tájban szereplő természeti és társadalmi tényezők szerepének, súlyának az értelmezése, főként az antropogén hatások tájformáló jelentőségének megítélése alapján különböző irányzatok alakultak ki (Mezősi-Bata 2011/a).

Alkalmazzák a koncepciót a hétköznapokban is, emiatt nem véletlen, hogy kusza fogalmi rendszer alakult ki körülötte. Így pl. a kert- és tájépítészek szerint a táj a természeti alapokon a társadalmi tevékenységek hatására jön létre, folyamatosan változik, alapvető keretében azonban állandónak kezelhető együttes (Csima P. 2009).

Az eltérő koncepciók sokakban vetik fel a kérdést, hogy léteznek-e egyáltalán a tájak, mint objektumok? Vannak, akik a tájat alapvetően esztétikai kategóriaként kezelik. Az Európa Tanács 2000. évi tájegyezményében a táj: az emberi környezet meghatározó komponense, a természeti és a kulturális örökség sokféleségének kifejezője és az önazonosságuk alapja (EU Tájegyezmény 2000). Mások azt elsősorban funkcionális egységnek tekintik (pl. a mezö- és erdőgazdaság, regionális elemzés, tervezés területén). A sok értelmezés közötti bizonytalanságot idézi az az álláspont, ahol a táj tulajdonképpen csak fikció, lényegében önálló objektumként nem létezik.

Néhányan kézenfekvőnek tartják, hogy bizonyos esetekben a tájak - egy síksági, egy ártári és egy vulkáni hegységi táj valóban világosan elkülöníthetö, így a tájak gyakorlati célját csupán a térbeli tájékozódás elösegítésében látják (Hajdú-Moharos et al. 2000).

A természeti tájakat a (természeti) tényezők integrált egységeként értelmezzük. Az antropogén hatás mértéke azonban gyakran felülírhatja ezeket a kategóriákat, vagyis teljesen 
természetes tájakkal a jelentős antropogén hatás miatt napjainkban lényegében már igen ritkán találkozhatunk. Ugyanakkor lehet a tájakat főként az antropogén tevékenység által kialakítottnak tekinteni, ez a kultúrtáj koncepció alapja, amely jellemzően a társadalmi hatásra létrejött tájakat jelöli, ill. folyamatai főként antropogén szabályozottságúak (Kerényi2007).

A témában, az 1950-es években az orosz, a 1960-70-es években a német és a magyar nyelvü szakirodalomban szakmai viták bontakoztak ki (Mezősi 2003). Száva-Kováts 1965ben megjelent vitacikkében összefoglalta a szovjet és az amerikai, német tájviták föbb eredményeit, melyek, ha különböző mértékben is, de hatással voltak a különböző magyar tájértelmezések és - lehatárolások elkészítésekor.

A szovjet földrajzi elméletben a táj objektív valóság, a földrajzi burok reális egysége, része, de nem autonóm rendszer. Elkülönítése általában nem lehetséges vonalszerü pontossággal. A tájat természetes határok határolják és ezek a határok reálisak, legfeljebb különböző mértékben élesek (Regel - Winkler 1953).

Ezzel szemben az amerikai tájkutatók megközelítésében a tájfogalom tárgya, vagyis a táj határa a valóságban sehol nem található meg. A táj nem objektum, területe nem „önmagában meghatározott”, a táj fogalma intellektuális koncepció, eszköz az összetett földfelszíni jelenségek területi szétválasztására és tanulmányozására. Annyi tájrendszer és tájbeosztás van, ahányféle földrajzilag kutatásra érdemes probléma létezik. Ennek megfelelően a táj a földfelszín bármely része, mely az homogén a vizsgálat céljának megfelelő kritériumok szempontjából (James et al. eds. 1954).

A hagyományos tájszemléletben ( 1940-es évek vége) a földfelszín -elvben- földrajzi tájakból tevődik össze, azok összessége. A táj felosztható kisebb egységekre, viszont megoszlik a vélemény arról, hogy létezik-e egy komplex alapegység (tovább nem osztható egység) (Száva-Kováts 1965).

Tehát a táj elhatárolására kétféle megközelítés, eljárás kínálkozik:

a, A „Grenzgürtel”- módszerben a tájelemek természetének térbeli vizsgálata különböző határvonalakat eredményez. Ezek a határvonalak hol közelebb, hol távolabb futnak egymástól, a tájak határán azonban ,határ-övezet”-té (Genzgürtel = ökoton) sürüsödnek. A határ-övezetek kimunkálása és kartografikus ábrázolása a táj lehatárolásával egyenértékü (Maull 1936).

b, A „Kerngebiet”- módszer a tájat komplex módon igyekszik megragadni, ezért a legfontosabb táji-tényezők együtthatásaiból kialakuló legjellegzetesebb „mag terület”-et 
(Kerngebiet) jelöli ki és innen kifelé halad a vizsgálat a szomszédos tájak mag területei felé (Maull 1925).

A sor sok más természet- és társadalomtudományi (pl. néprajzi) megközelítéssel folytatható és emiatt a táj tartalmi értelmezésével kapcsolatos viták nehezen zárhatóak le.

\subsection{Tájdefiníciók}

A különböző tájértelmezések hatására más-más tájdefiníciók láttak napvilágot. Következőekben röviden szeretném bemutatni a tájdefiníció eredetét, majd a 20. század elejétől leggyakrabban használt magyar változatait.

A „táj” megnevezés a 15-16. századi holland festőktől származik (landschap). Ez az „egységes földrajzi” kategória az idő folyamán sokat módosult, tartalma értelmezése is változott (Naveh - Liebermann 1984).

Az egységes földrajz alapját, egyben a földrajzi tájkutatás alapjait a térbeli, komplex szemlélet alkalmazásával 19. század elején (1807) Alexander von Humboldt rakta le. Humboldt a tájat „totalcharacter einer Erdegegend”-nek határozta meg, vagyis a táj földfelszíni egység össztulajdonságainak megjelenése (Csorba 1997).

A földrajzi dualizmus elöretörésével a táj fogalma kettévált: egyrészt természettudományi kategória természeti tájjá, másrészt az egységes földrajzi tájjá. Az angolszász irodalomban a természeti tájat kiegészítették a természet és a társadalom közti kölcsönhatások leírásával, így született meg a kultúrtáj fogalom.

Ugyanakkor a tájakat már a ma használatos földrajzi megközelítés előtt is a természeti és társadalmi tényezők laza együtteseként írták le és határozták meg. Kogutowicz $(1930,1936)$ tájleírásai néprajzi, történeti tájhasználati és természeti tényezőkön alapultak. A tájjal foglalkozó kutatók között kétség nem volt a tájak létezésében, de tartalmukban, kiterjedésükben már igen Kogutowicz például az etnográfiai határ alapján határozza meg a tájat (pl. az Ormánság a neve a domborzatra utal) vagy amikor orográfiai adatokhoz illeszti a tájakat (pl. Mecsek). Eltérö koncepciókkal született egységek ugyanis nehezen jelenthetik az egzakt tájlehatárolás alapját, sőt sok olyan „táj” is megjelenik, melynek földrajzi integrált egység értelmében a léte is kétséges (pl. az őshonos népesség neve után Alvidék, vagy Drávaszél (Kogutowicz 1936). 
Ezzel szemben Teleki (1936) meghatározásában a táj: „,a földfelszíni élet természettől való synthesise a Föld bizonyos pontján, területén... Nincs két egyforma táj a Földön... Ha a tájak egyéniségek, individuumok is, a Föld nincs belölük sakktábla vagy puzzle-játék szerüen összetéve. A tájak csak ritka esetben határoltak egészen élesen, rendesen átmenetek vannak köztük, legtöbbször észrevétlenebbül olvadnak egymásba." Teleki megközelítése alapján a tájlehatárolás közelebb áll a „Grenzgürtel”- módszerhez, hiszen véleménye alapján nem határolhatók le a tájak élesen, mely megfelel a modern tájkutatás kívánalmainak, ha a célunk a valósághü ábrázolás, nem pedig a gyakorlati (tervezési) célú tájhatár „merev” vonallal történő megvonása.

Az 1940-es években világossá vált, hogy a (természeti) táj bizonyos tényezők, ún. tájalkotó tényezők összetett együttese, egyedi, specifikus földrajzi területegység (Kádár 1941).

Az 1940-es években még nem kezdődött el a tájdefiníciók gyakorlati alkalmazásai, a különböző lehatárolások elkészítése, viszont a különböző megközelítések hasonló szakmai tájvitákat „robbantottak” ki, mint amelyek Nyugat-Európában és Amerikában voltak.

Az előzőekben bemutatott magyar tájdefiníciók közös elemei a tájalkotók együttes vizsgálata, integrálása, illetve a természeti tényezőkön kívül a társadalmi hatások vizsgálata is:

„A korszerü természeti földrajz művelőinek többségi véleménye szerint az övezetesen tagolódó földrajzi burok zónáinak taxonómiai egysége a természeti táj” (Bulla 1964). Az elnevezés tükrözi a társadalmi tényezők hatásait is. A természeti táj természettörténeti kategória, hosszú, ritmusos fejlődés eredménye, a táj jelenlegi képe a fejlődés pillanatnyi állapotát jelzi, vagyis a táj örök változásban, fejlődésben lévő természeti egység, individuum. A természeti táj a tájalkotó (tájalakító) tényezőknek fejlődésben ellentmondásos, diszharmonikus egysége. A táj komplex egység: a domborzat, az éghajlat, a vizek, az élővilág, és a talajszféra mozgásfolyamatai szövődnek benne össze térben és időben változó sajátosságok együttesévé. Nincs tehát önállóan csak pl. domborzati - vagy talajtáj, viszont a tájképző, tájalakító tényezők földrajzi zónánként nem azonos értéküek, nem azonos jelentőségüek. Ha viszont a táj összes tényezője (összetevője) határozza meg a tájat, akkor nem helyes csak természeti tájról és mütájról beszélni, hiszen a társadalmi nem passzív alkotója a tájnak, inkább alakítója, helyenként igen domináns tájtényező (Góczán 1961).

A tájképző tényezők a különböző földrajzi zónákban különböző értékűek, fontosságúak, hazánkban, a mérsékelt övi folyóvízi eróziós klimatikus morfológiai zónában a táj 
fejlődésének legfontosabb irányítója a folyóvíz eróziós és akkumulációs tevékenysége, a domborzat a táj váza ezeken a területeken (Bulla 1964).

Bullához hasonlóan ma is sokan elfogadják, hogy a regionális értelemben vett tájak több vagy néhány különböző tájtípust is magukba foglaló individuális területi egységek. A regionális táj sem tekinthető döntően természeti táj-fejlődéstörténeti kategóriaként, csak a természetföldrajzi, földtani tényezők hosszantartó és állandó fejlődésének pillanatnyi állapotaként. Az éghajlati adottságok mellett az ország természetes tájtípusait a szerkezeti geomorfológiai tényezők határozzák meg (Pécsi et al. 1972). Tehát a geomorfológiát (domborzatot), mint tájalkotó tényezőt kulcsparaméternek tartották, tájlehatárolásuk során e tényező nagyobb súllyal szerepel. Viszont az egyes tényezők súlyozása, majd integrált elemzése nem oldható meg egzakt módszerekkel, az egyes a tájalkotó tényezők (pl. domborzat) jelentőségét, súlyát nehéz számszerüsíteni.

Az 1980-as évektől kezdődően egyre elterjedtebbé vált a táj - meghatározások hosszabb leírásai helyett, a tömörebb, definíciószerű tájfogalmak közlése:

A tömörebb tájdefiníciók közül gyakran idézett meghatározásban a táj ,,a térnek olyan, a szomszédságtól a hierarchiai szintnek megfelelően többé-kevésbé elhatárolódó egysége, amely a természeti és - egyre inkább - antropogén folyamatok és törvényszerüségek kölcsönhatására egyéni sajátosságokkal rendelkezik. Bár arculata az élö szervezetek, az ember, a társadalom hatását is tükrözi, ennek eredményeként is nagymértékben formálódik, de térbeli alapja, határainak meghatározója a természeti tényezők összessége.” Marosi (1980).

A gyakorlati tervezés során gyakran használt 1996. évi LIII. a természet védelméről szóló törvényben a táj fogalma: „A táj a földfelszín térben lehatárolható, jellegzetes felépítésű és sajátosságú része, a rá jellemző természeti értékekkel és természeti rendszerekkel, valamint az emberi kultúra jellegzetességeivel együtt, ahol kölcsönhatásban találhatók a természeti erők és a mesterséges (ember által létrehozott) környezeti elemek” (1996. évi LIII. törvény).

Mindkét definíció elfogadható, hiszen bennük helyesen megjelenik, hogy a táj alapját a természeti tényezők alakítják ki, de az antropogén hatás azt bármikor felülírhatja. Marosi (1980) definíciója azonban abból a szempontból jobban használható, mivel a tájalkotó tényezőkből felépülő tájak határainak valósághűbb ábrázolásához közelebb áll a „,többékevésbé elhatárolódó egysége"- megfogalmazás.

A dolgozatomban a közepes méretarányú tájökológiai egységek lehatárolásánál használt táj definíciója szerint: a táj a földfelszín egy konkrét részlete, amely szerkezete és müködése alapján egy egységet alkot, és ez jól látható módon is elkülöníthetővé teszi a szomszédos 
tájaktól. A táj arculatát természeti sajátságainak összessége és a rajta elő, lakó, tevékenykedő emberek együttes hatása határozza meg (Pécsi et al. 1972). Vagyis a táj integrált rendszer, a tájalkotó tényezők együttesen (kulcsparaméterek kijelölése, illetve azok súlyozása nélkül) határozzák meg táj sajátos arculatát.

\subsection{A tájak határainak értelmezése}

A tájak különböző forrás-, valamint derivátum-adataival kapcsolatos egységek határainak pontos ismerete fontos, amelyek a szaktudomány által igényelt válaszokon túl a gyakorlati alkalmazások (pl. gyakorlati tájtervezési, tájrendezési, tájvédelmi feladatok ellátása) miatt is lényegesek lehetnek. Szaktudományi szempontból a területegység tudományos meghatározottságának igénye fogalmazódik meg, az a kívánalom, hogy ismerve és helyesen alkalmazva a táji egységek (típusok) meghatározásának technikáját, ez alapján a különböző értékelők azonos egységeket ismerjenek fel. A lehetőségek szerinti pontos táji (területi) meghatározást az is igényelheti, hogy ezek az egységek egyben a földrajzi rendszerek müködő alapelemei is.

A tájhatár kérdésével már Prinz (1936) is részletesen foglalkozott, aki szerint az nem természeti „elválasztókat keres”, hanem a sok természeti és társadalmi hatás következtében létjött közigazgatási vonalakhoz illeszkedik inkább. Mint utaltam rá, a táj tartalma az elmúlt 60-80 évben sokat módosult és föként megváltozott az a szakmai környezet (pl. néprajzi Kogutowicz 1936, vagy morfológiai - Bulla 1964), amilyen körben ezeket értelmezték.

A régebbi koncepciójú tájbeosztások és az utóbbi 20 évben született tájlehatárolások, csak a nagytáj és a középtáj szintjén mutatnak egyezéseket. A tájak föleg alacsonyabb hierarchia szinten mutatnak területi állandóságot, amire jó példa, hogy egy kistájon pl. a vegetáció (mely az antropogén tényezőkhöz hasonlóan gyors változásra képes) is csak néhány km-nyi kilengést mutat a táj központi „magja” mentén. A tájak határait sávként tekintik (ökotonok), és a határok szélesebb zónaként történő értelmezését is felvetik (Bastian 1997, Csorba 2008).

A gyakorlatban a tájak területi kiterjedését az ökotópok határai szabhatják meg, amelyeket pedig a tájalkotó tényezőkön keresztül írunk le. A regionális egységek pontos meghatározásának számos tényezője ismert a méretaránytól kezdve a tájalkotó tényezők integrációjának mértékéig. A táj fogalommal jelölt természeti egységek helyi lehatárolása - a korábbiakban bemutatottak szerint - fontos szakmai kérdés. Így a kérdés most nem az, hogy érdemes-e, hanem lehet-e pontosan a lehatárolást elvégezni. A befolyásoló tényező közül az alábbiakat emelem ki: 
a, Az egyik a tájalkotó tényezők határainak megállapítása, amit elvileg is csak korlátozott pontossággal lehet tenni, mert ezeknél a határ nem vonható meg élesen. Így pl. szakmailag sem egyszerű eldönteni hol húzhatjuk meg két talajtípus határát (pl. egy réti és egy láptalaj átmenete néhány 10 vagy néhány $100 \mathrm{~m}$-es zónát érint), de ugyanez a helyzet a geomorfológiai formákra, vagy az egymást még inkább átható vegetáció típusokra. A vegetáció topjánál nemcsak e térbelinek nevezhető pontosság korlátozott, hanem az időbeli is, mert a típusok fejlődése, átmenet egyikből a másikban még itt, a leggyorsabb természeti eredetű változásnál is 10-100 év mértékü (Csorba 2008, Kerényi 2007). Kísérletezhetünk a tájalkotók határainak pontosításával, amelyekhez használhatunk különböző geostatisztikai eljárásokat (Mezősi - Bata 2011/b), vagy terepi mintavételezést is, de ezek csak nagyon korlátozottan tekinthetők valóban az integrált táj határainak (Hegedűs 2006, Deák 2008, 2010, Molnár et al. 2008, 2010). Ezek többnyire egy vagy néhány, esetleg súlyozott természeti tényezőre vonatkoznak, de a szerzők értelmezésében ez a táj egészét reprezentálja. Az integrációt jobban szolgálja a MÉTA vegetáció térképe, amelyben a növényzeti adatokon túl néhány más természeti (talajtani, domborzati, éghajlati) tényezőt, nem integráltan ugyan, de figyelembe vesz. (Ami viszont a redundancia miatt a felhasználást korlátozza.)

b, A másik a tájak meghatározásával kapcsolatos tartalmi pontatlanság, ami a táj integrált alapegységeinek meghatározásával kapcsolatos. Itt ugyanis tisztázni kell, hogy milyen tényezőket, milyen súllyal veszünk tekintetbe az egységek (ökotópok, vagy kistájak) meghatározásnál: pl. egy síkságon, egy hegységben az orográfiát, vagy a litológiát meghatározó paramétert ugyanolyan fontosnak, súlyúnak tekintjük-e vagy sem, és milyen tényezőket indokolt figyelembe venni a tájak meghatározásánál. A pontatlanság itt abból adódik, hogy lényegében nincs statisztikai, rendszerelemzési háttér az integrált táji egységekhez szükséges tényezők megállapítására, ráadásul tapasztalatból azt tudjuk, hogy azok más területeken eltérő fontosságúak, súlyúak (Bastian - Schreiber 1994). Az integráció még összetettebb az antropogén tevékenység által kialakított kultúrtájaknál.

c, A táj pontos meghatározásának harmadik korlátja technikainak nevezhető, mely a méretaránnyal kapcsolatos (Mezősi - Bata 2011/b). A napi tájtervezési gyakorlat során ugyanis nagyon eltérő méretarányokban kell lehatárolni a táji egységeket. Munkájukhoz nagy méretarányt igényelnek pl. a településrendezési tervek, kisebb léptéket pedig pl. a megyék, kiemelt térségek területi tervek. A határ megvonására vonatkozó, ugyanolyan százalékos hiba a nagyobb méretarányokban már többnyire nem elég pontos a tervezéshez (egy erdősáv, vagy egy partmenti, vízminőségi pufferzóna tervezéséhez), míg a magasabb hierarchia (pl. kistájcsoport, középtáj) szinten a keletkező km-es hibák áttekintő vizsgálatokra alkalmasak csak 
(Csima et al. 2004, Csorba 2008). Ehhez kapcsolódó probléma, hogy a különböző méretaránynál a hatótényezők más kapcsolati rendszerével találkozhatunk (Mezősi 2009).

A tájhatárok bizonytalanságát azok sokfajta tartalmi értelmezésen túl természeti/társadalmi hatások aránya is okozza. Ma Európában tisztán természeti tájak jószerint nem léteznek, mert mind kisebb-nagyobb mértékben az antropogén hatások eredményeképp fejlődtek. Emellett a „természeti meghatározottságú” tájak változása általában sokkal kisebb álalakulást okoz, mint egy-egy antropogén hatás, amely teljesen felülírhatja a táj mintázatát, tartalmát. Összességében azonban alapvetően a természeti tényezők jelölik ki a táj határait, de azok a társadalmi elemeket is magába foglaló összetett rendszert alkotnak. A tájakkal kapcsolatos vizsgálatoknak ez a legsérülékenyebb pontja.

\subsection{Magyarország tájföldrajzi beosztásai}

Magyarországon a különböző országos léptékü tájbeosztásokat a 20. század elejétől készítettek. Kezdetben, az 1960-as évek elejéig általánosságban elmondható, hogy a felosztások a nagytájak szintjén valósultak meg:

Cholnoky (1929) hazánk területét kilenc nagytájra osztja: Alföld, Dunántúl, Erdélyi medence, Keletmagyarországi Szigethegység, Északnyugati Felvidék, Keleti Kárpátok, DélErdélyi Felvidék, és Dinári Alpok.

Mint korábban említettem, esetenként találkozhatunk olyan véleményekkel, melyek szerint a tájak elkülönítése „csak a térképen készült közhasználatra, tájékoztatásra, gyakorlati célból” szükséges. A tájhatár nem természeti „elválasztó” vonal, inkább a sok természeti és társadalmi hatás következtében létrejött közigazgatási egységek határaihoz illeszkedik. Ezen nézet egyik képviselője volt Prinz, aki ennek ellenére elkészítette saját többszintü (országrészek, tájak, vidékek) beosztását Prinz (1936) az akkori (Trianon előtti) Magyarország területére (2.1. ábra). 


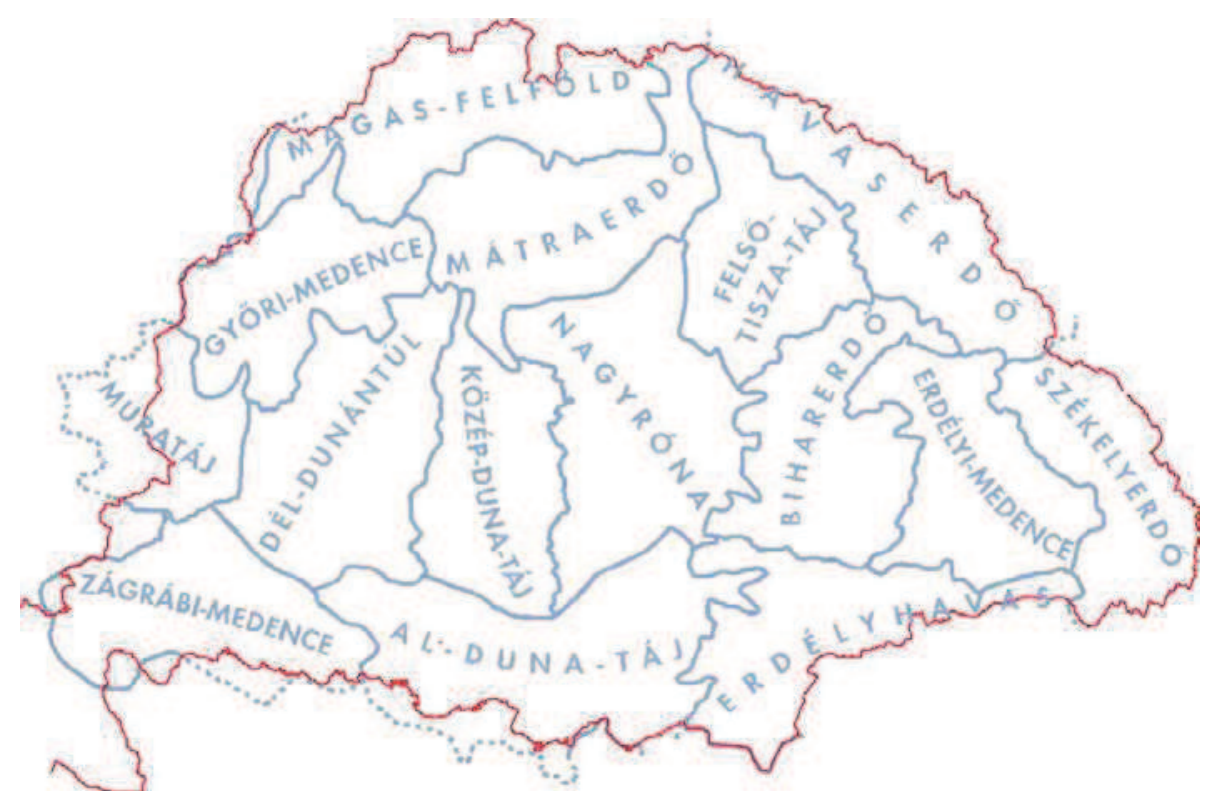

2.1. ábra: A tizenöt táj Prinz Gyula tájtagolásában (Lukács 2006)

Az 1940-es évek elején készítettek olyan „tájfelosztást” is (2.2. ábra) a Trianon előtti Magyarország területére, mely a tájak nevezéktanának pontosítását szolgálta nagytáj és középtáj szinten egyaránt (Kádár 1941).

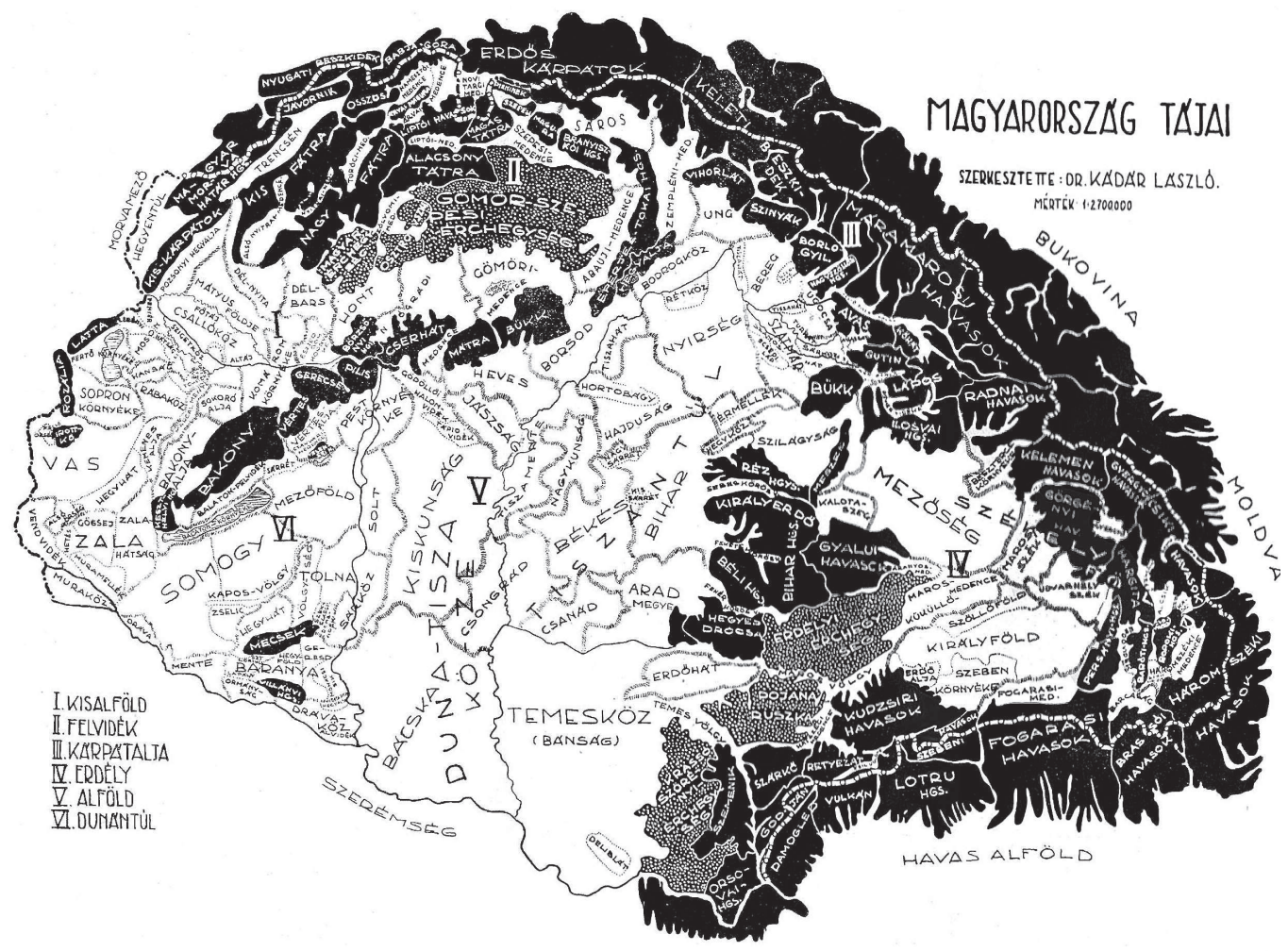

2.2. ábra: A Trianon előtti Magyarország tájai Kádár (1941) felosztásában

A 2.2. ábrán látható nagytáj-szintű elnevezésekkel és lehatárolással nagyrészt átfedésben van a Kárpát medencének azon beosztása is, mely azt az alábbi tájakra osztja fel: Alföld, Kisalföld, Dunántúl a Dráva-Száva közével, Északnyugati Felvidék, Északkeleti Felvidék, Erdély (Bulla - Mendöl 1947). 
Később megjelentek a több hierarchia-szinten részletesebben (nagyobb méretarányban) ábrázolt tájlehatárolások. A tájföldrajzi felosztása során a nagytájak elkülönítéséhez a domborzati és nagyszerkezeti viszonyokat vették figyelembe. A középtájak meghatározásához a külső és belső erők finomabb részletei: az éghajlat, a vízrajz, a talaj- és növénytakaró sajátosságai, a kistájak lehatárolásához a mezo- és mikromorfológiai formák szolgáltak alapul. Láng négy nagytájra osztotta fel Magyarországot: Alföld, Kisalföld, Dunántúl, Északi középhegység, és harmincegy középtájra. Ez a geomorfológiai alapú középtáj-beosztás nagyjából megegyezik a növényföldrajzi és az átnézetes talajföldrajzi tájbeosztással. A kistájakra való felosztása (2.3. ábra) zömmel csak a geomorfológiai formák figyelembevételével készült el. Láng ugyanakkor felhívja arra a figyelmet, hogy a kistájak körülhatárolásánál a természeti tényezők komplexitásának maradéktalan szem előtt tartása nehezebb, mint a középtájak esetében Góczán 1961).

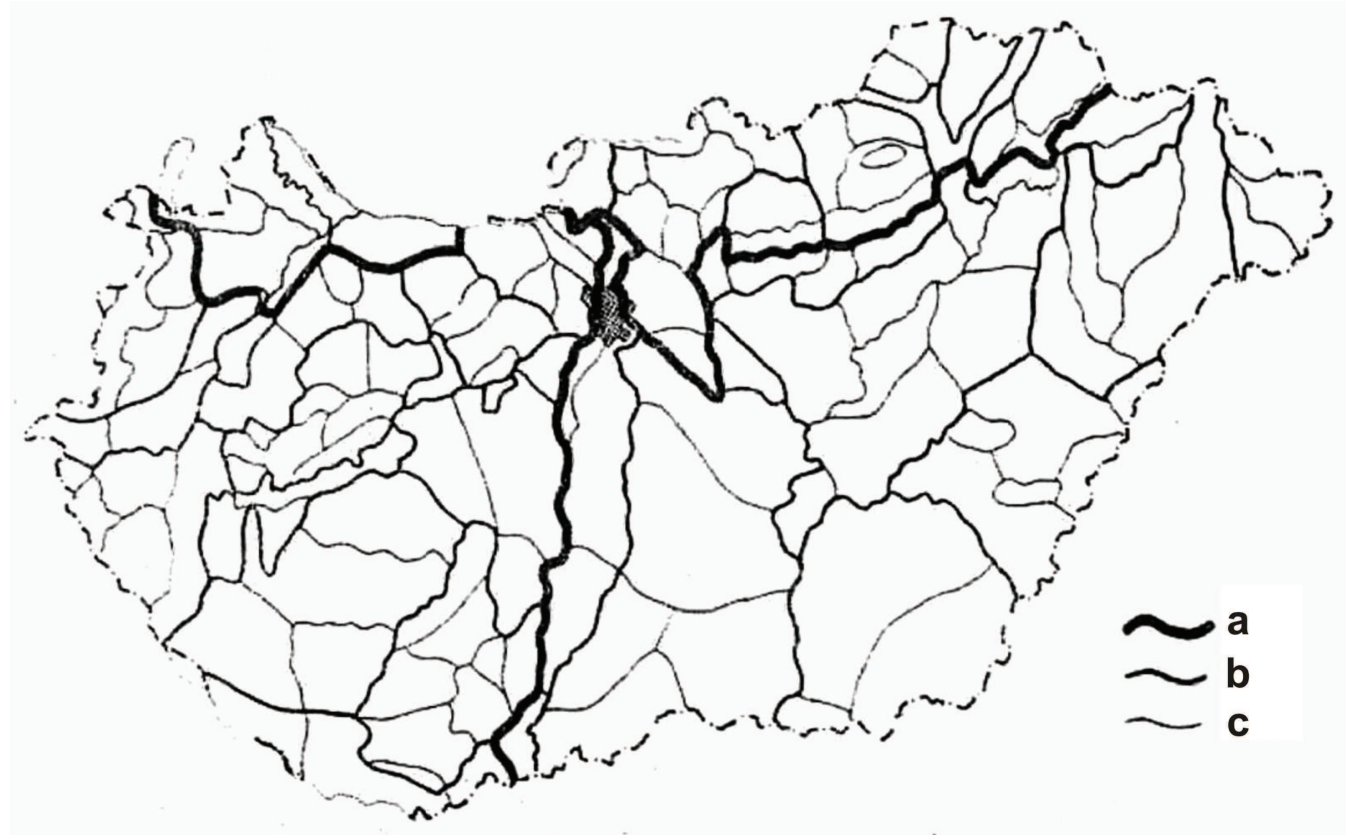

2.3. ábra: Láng tájbeosztása: a-kistáj határa, b-középtáj határa, c-nagytáj határa (Góczán 1961)

A természeti tényezők figyelembevételével, ezzel szemben Bulla (1964) már több, hat komplex területi egységre, nagytájra osztotta fel Magyarországot. Felosztása alapján ettől kezdve már külön nagytájként kezeljük a Dunántúli dombságot és a Dunántúli középhegységet és megjelenik az Alpokalja, mint önálló nagytáj is, az Alföld, Kisalföld és az Északi - középhegység mellett. 
Bulla tagolásának alapja a tájalkotó tényezők kapcsolódásának minőségi különbségei, a nagytájak között csak mellérendeltégi viszonyok vannak, a nagytájakat továbbosztotta résztájakra, a résztájakat a 2.4. ábra szerint kistájakra tagolta (Góczán 1961).

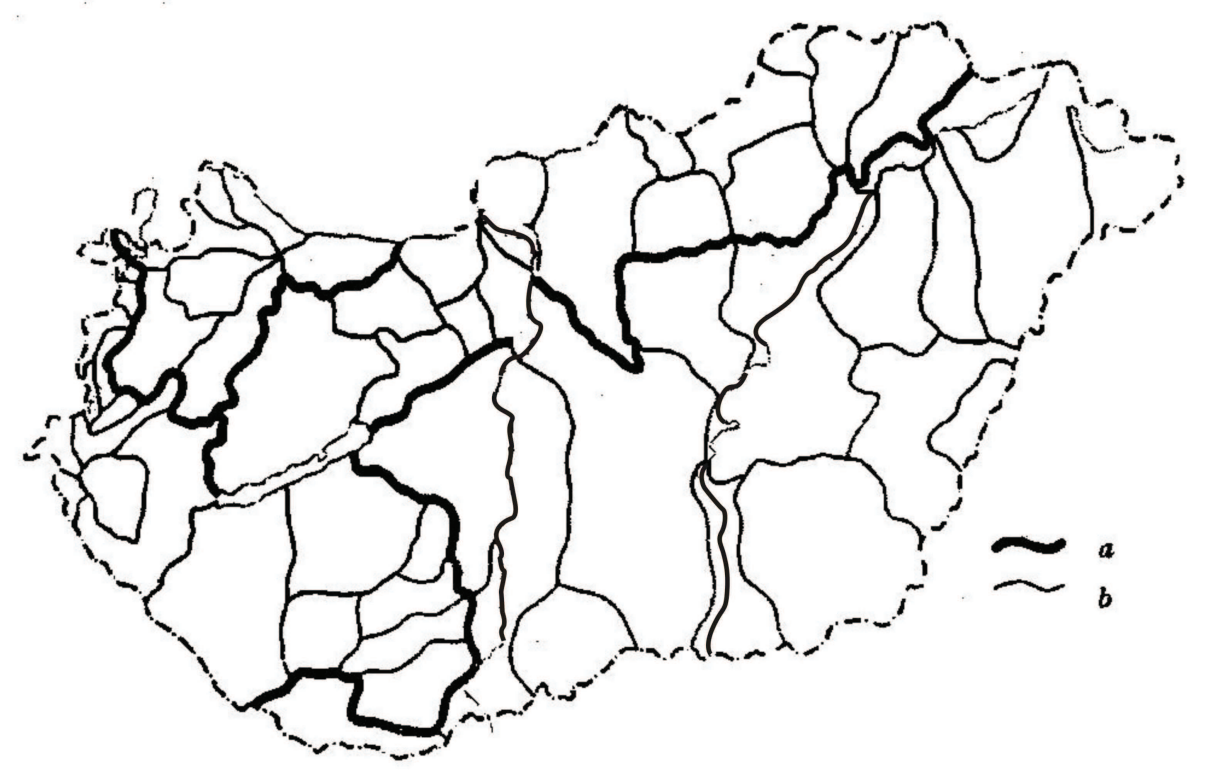

2.4. ábra: Bulla Béla tájbeosztása: a-nagytáj határa, b-kistáj határa Góczán (1961) alapján

A felosztás elkészítése mellett azonban leszögezi, hogy a tájak nem különülnek el egymástól éles határokkal. Az egyéni tájvonások fokozatosan halványodnak az egyik, illetve erösödnek a másik tájban, vagyis a tájak közé átmeneti sávok, övezetek iktatódnak, melyek hovatartozása vitatott lehet pl. Mezőföld az Alföld vagy a Dunántúli dombság része? (Bulla 1964).

1961-ben az MTA Földrajzi Bizottsága és Földrajztudományi Kutatócsoportja közös ülésén megvitatták a Magyarország természeti földrajza c. monográfia alapjául szolgáló tájbeosztást. A vita során egyöntetűen hangsúlyozták a nagytájak kijelölésénél az összes tájalkotó tényező szigorú figyelembevételét. Az egyes tájalkotó tényezők dominanciájának kérdése a konkrét nagytáj-középtáj beosztással kapcsolatosan merült fel. Bulla és Láng tájfelosztásai részletes bemutatását követően az ülésen egyöntetüen sem a Bulla - féle beosztást, sem a Láng - féle beosztást nem fogadták el. Növényföldrajzi és éghajlati alapon a nyugat-magyarországi területsávot önálló nagytájként javasolták elkülöníteni (neve: Alpokalja - Bulla felosztásához hasonlóan). Az ülés eredményeképp kijelölték a nagy-és középtájakat, a kistájak elhatárolását szűkebb szakbizottságra bízták (Góczán 1961). 


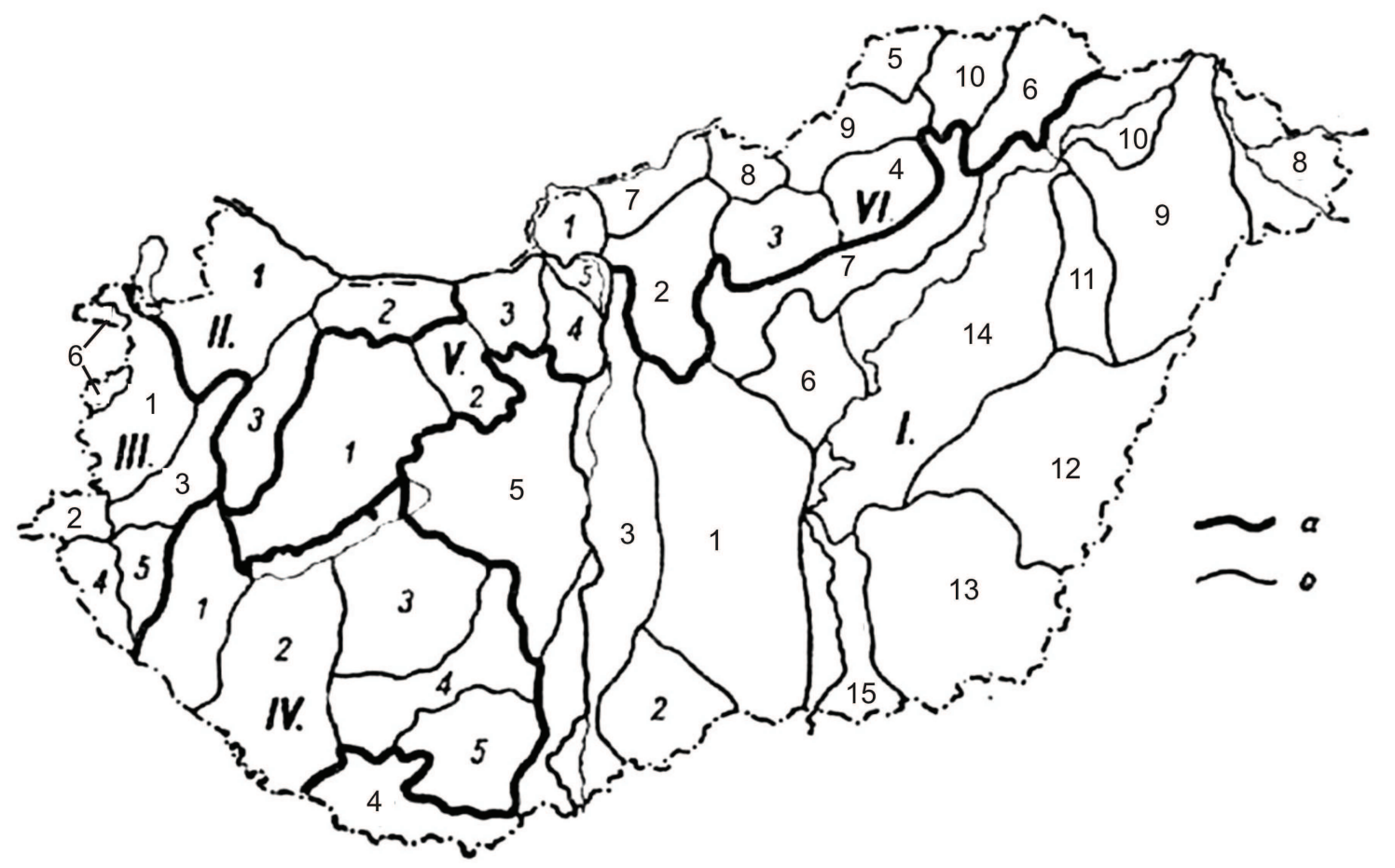

2.5. ábra: A vita alapján a bizottság által készített tájbeosztás (Góczán 1961) a-nagytáj határa, b-középtáj határa

I.-Alföld:1-Duna-Tisza közi hátság, 2-Bácskai-lösztábla, 3-Dunamenti-síkság, 4-Drávamenti-síkság, 5Mezőföld, 6-Jászság, 7-Észak-alföldi hordalékkúpok, 8-Bereg-szatmári-síkság, 9-Nyírség, 10-Bofrogköz a Rétközzel, 11-Hajdúság, 12-Körösvidék, 13-Körös-Maros köze, 14-Közép-Tiszavidék, 15-Alsó-Tiszamente. II-

Kisalföld: 1-Györi-medence, 2-Györ-tatai-teraszvidék, 3-Marcal-medence. III. Alpokalja: 1-Rábántúli

kavicstakaró, 2-Vasi-Hegyhát, 3-Kemeneshát, 4-Nyugatzalai dombság, 5-Göcsej, 6-Soproni- és Köszegi hegység. IV-Dunántúli dombság: 1-Keletzalai-dombság, 2-Belső-Somogy, 3-Külsö-Somogy, 4-Tolna-baranyai dombság, 5-Baranyai szigethegységek. V-Dunántúli középhegység: 1-Bakony, 2-Vértes a Velencei hegységgel, 3-Gerecse, 4-Budai-Pilisi hegység, 5-Visegrádi hegység. VI.-Északi középhegység: 1-Börzsöny, 2-Cserhát, 3-

Mátra, 4-Bükk, 5-Aggteleki -karszt, 6-Zempléni-hegység, 7-8-9-Nógrádi-borsodi medencék és környező dombság, 10-Cserehát.

A vitát követően a szakbizottság a megbeszélt kulcsfontosságú tényezők alapján elkészítette a hazai tájbeosztást (2.5. ábra). A szakbizottság tájosztályozásának alapját a különböző táj-és természettudományi, ágazati geológiai, éghajlattani, talajtani állat- és növényföldrajzi, vízrajzi és főként geomorfológiai térképek és monografikus feldolgozások értékelése, ezen tájalkotó elemek együttes integrálása jelentette. A beosztás vázát, - egyben legfontosabb tájalkotó tényezőit - a morfo-litogén elemek térbeli elhelyezkedése adták (Pécsi - Somogyi 1967).

A tájfelosztásuk legmagasabb taxonómiai, hierarchikus egységei a nagytájak, melyek valamely domborzati típus egészére (síkság, dombság, hegység) terjednek ki, amelyekben a többi tájalkotó tényező lényegében azonos természeti környezetet alkot. Vagyis az egyes nagytájak a domborzat tekintetében homogének, viszont a többi tájalkotó tényező alapján a homogenitás itt a legkisebb. A nagytájakon belül középtájakat különítettek el, melyek: többféle típusú tájrészek megismétlődő kapcsolódása. Néhány tényező azonos a középtájon 
belül (pl. azonos domborzati típuson belül azonos fejlődéstörténet, felépítési adottságok, vagyis a tényezők homogenitása itt már nagyobb. A lehatárolás következö, alacsonyabb szintje kistáj-csoportoké, melyek az egymás mellett megismétlődő kistájak csoportjai. A következő szint tehát a kistájak szintje, melyek aránylag kevés rokon, vagy azonos típusú tájrészek együttesei (a felosztásban a tájalkotó tényezők homogenitása itt a legmagasabb) (Pécsi - Somogyi 1967).

Az angolszász, orosz és német irodalomban a kistájak szintje még tovább bontható az ökológiai fáciensekre, ökotópokra (tájsejt), melyek az összes tényező szempontjából homogén egységeket jelenti. A térben egymás mellett fekvő több tényező szempontjából is azonos vonásokat mutató ökológiai fáciensek ökológiai fácienscsoportokat (tájsejtegyüttesek) alkotnak (Schmithüsen 1963, Troll 1950, Neef 1967, Isachenco 1953).

Az 1990-ben jelent meg Magyarország kistájainak katasztere I.-II. (Marosi - Somogyi szerk. 1990), melyben az 1967-ben kialakított tájbeosztás helyenként módosított egységeinek térképét (2.6. ábra), illetve részletes jellemzését találhatjuk). A kistájkataszter széles olvasói és felhasználói réteg igényeit merítette ki a földrajzi társadalomban, nemcsak kutatások, hanem főként kistérségi tervek kidolgozásaihoz is felhasználták a kistájkataszterben az egyes kistájakról szóló részletesen leírásra kerülö ismereteket. A terjedelmes kézirat két kötete kistájanként tíz témakörben jellemzi a tájalkotó tényezőket. A kistájak jellemzésekor az egymástól eltérő területegységek fontosabb, főleg természeti környezeti tényezőit vették figyelembe. Ennek alapján a témakörök: helyzet, területhasznosítás, domborzat, földtani adottságok, éghajlat, vízrajz, természetes és termesztett növényzet, talajok, sajátos táji adottságok bemutatása, tájtipológiai összegzés. A feldolgozás alapelveit, módszereit befolyásolta, hogy a feldolgozás során használt adatok különböző forrásokból származtak (Marosi - Somogyi szerk. 1990). 


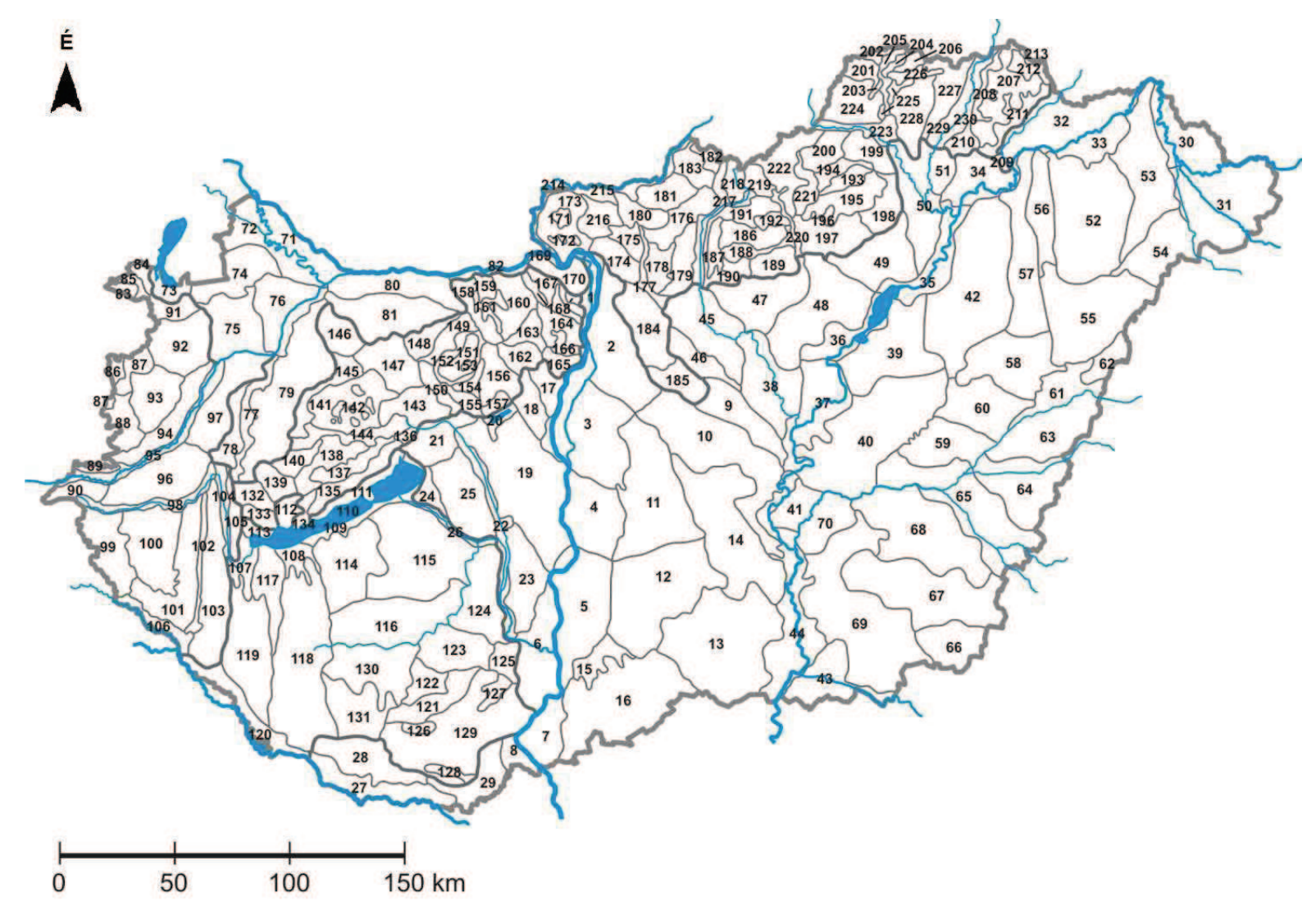

2.6. ábra: Magyarország kistájai az 1990-es beosztás alapján. A számokkal jelölt kistájak listáját az 1. sz. melléklet tartalmazza.

A sokirányú igény és érdeklődés, melyet a kistájkataszter I. kiadása iránt tanúsítottak indította arra a MTA Földrajztudományi Kutatóintézetet, hogy az újabb kutatások felhasználásával, módszertanilag korszerüsítve, tartalmilag releváns adatokkal frissítve és új tematikus egységekkel kibővítve (a közlekedés, településhálózat és a népesség jellemzőivel kiegészítve) új változatban jelentesse meg a művet, viszont a tájak határait nem módosították (Dövényi szerk. 2010).

A probléma a kistáj kataszterekben megtalálható, (leggyakrabban használt) tájfelosztással kapcsolatban az, hogy a lehatárolás nem a kistájakat meghatározó tájalkotó tényezők klasszikus, tudományosan megalapozott integrálásának eredménye, hanem csupán a területi tervezési tervezési feladatokhoz szükséges kistáj-szintü határokat állítottak elő, illetve ezekről az egységekről leíró jellegü, meglehetősen statikus földrajzi információkat szolgáltattak. 


\subsection{A tradicionálisan definiált tájfelosztás bírálatai, módosítási javaslatai}

A Magyarország kistájainak kataszterében (Marosi - Somogyi szerk. 1990) bemutatott és napjainkig általánosan elfogadott tájfelosztás szakmai értékelése nehéz feladat, mivel nincs elfogadott szabvány arra, hogy milyennek kellene lenni a tájfelosztásnak, ezáltal nincs kidolgozott minőségi értékelési szempontlista a felosztás értékeléséhez. Mindez abból adódik, hogy a szerzők által használt táj definíciója sem egy egyenlettel meghatározható, számszerűsíthető fogalom, azáltal a lehatárolás sem egzakt (matematikai összefüggésekkel leírt) szabályok szerint történt. Dolgozatom további részében ezen felosztás egységeit „tradicionálisan definiált kistájak” néven említem.

A felosztás szubjektív elemek miatti pontatlanságát mutatja az, hogy az elmúlt évtizedben számos „bírálat” jelent meg az egyes kistájak, kistáj - csoportok vizsgálatakor, illetve olyan javaslatok is napvilágot láttak, melyek az egyes kistájak, kistáj - csoportok határainak módosítására tesznek javaslatokat.

Ezen tanulmányokban szereplő vizsgálatok módszertanilag igen változatosak. Vannak, melyek a természeti tényezőkön kívül vizsgálják a területre jellemző társadalomföldrajzi elemeket, hatótényezőket is, míg mások terepi vizsgálatokat, a tájról gyüjtött ismereteket (tapasztalatokat) is felhasználnak a bírálatokhoz, illetve javasolt új lehatárolások kidolgozásakor. A teljesség igénye nélkül, a módszertanilag változatos kutatási eredményekből kiemelnék néhányat:

a, Több kutató (Csapó 2008, Bokor 1989, 1996, 2007) részletesen foglalkozik az Örség (Alsó - Örség) elhatárolásának problémájával, egy új, pontosabb lehatárolás elkészítésével (2.7. ábra). Munkájuk során több szempontot vettek figyelembe (történelmi adatok, különböző (elsősorban földrajzi) leírások, természetföldrajzi, településszerkezeti sajátosságok, - elnevezések, statisztikai besorolás, néperedet, vallás elterjedés).

A tradicionálisan definiált kistáji beosztást (Marosi - Somogyi szerk. 1990) föként a természetföldrajzi szempontú vizsgálatkor bírálják. A történeti Örség efajta beosztás szerint három kistáj részét is képezi, még tágabban értelmezve az Örséget, további két kistáj tartozna a történeti Őrség területéhez. 

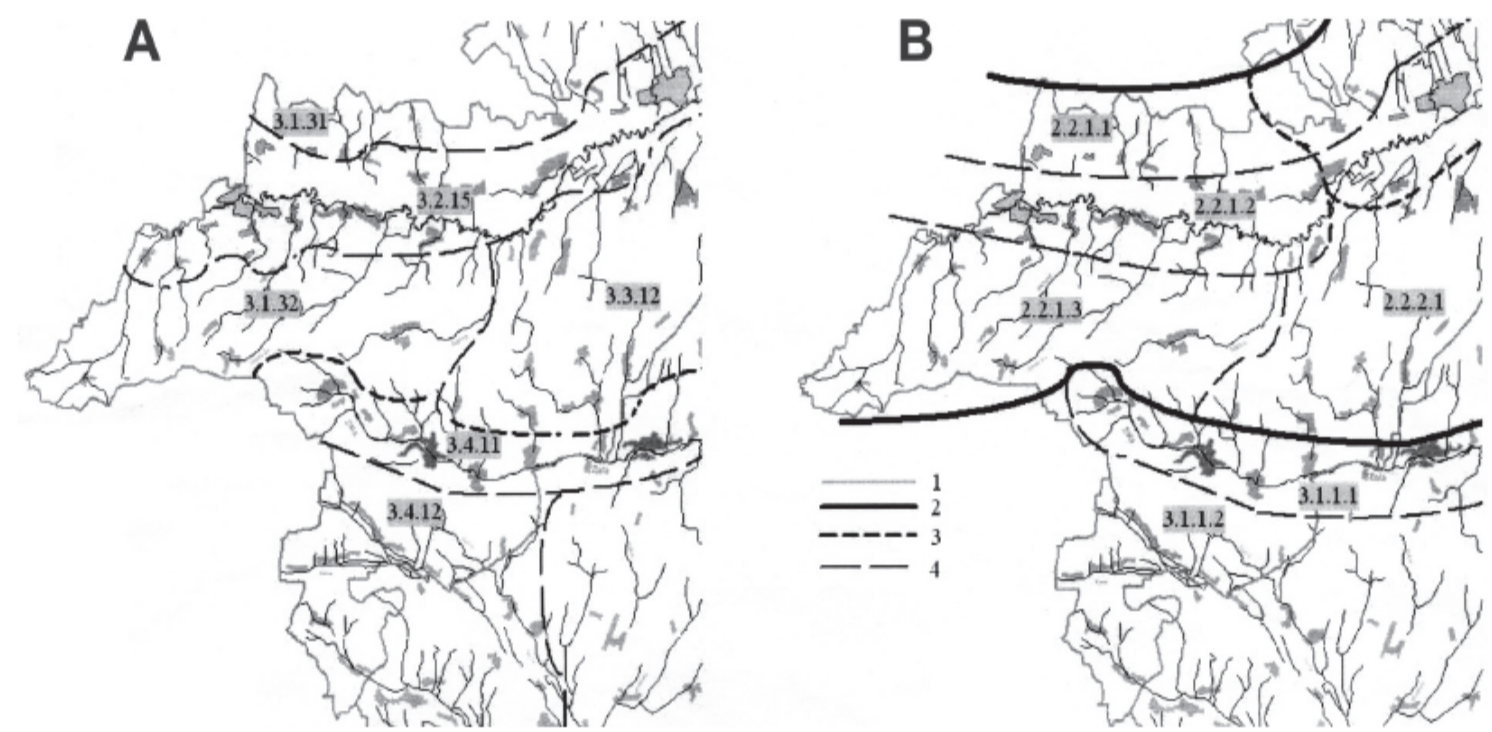

2.7. ábra: Az Örség természetföldrajzi tájai Marosi - Somogyi szerk. (1990) szerint (A) valamint Bokor (2007) szerint (B): 1-ország- és megyehatár, 2-nagytáj határa, 3-középtáj határa, 4-kistáj határa (Csapó 2008)

A szerzők egyetértettek abban, hogy a területre vonatkozóan a kistájak névadása több helyen helytelen, nem egyezik meg a különböző történeti, településföldrajzi, néprajzi kutatások eredményeivel. Véleményük szerint legalább a tradicionálisan definiált kistájak elnevezését módosítani kellene, viszont minkét kutató elkészítette a területre eső tájak határainak módosítási javaslatait (2.7. ábra).

b, A Sárrét kistáj határáról összefoglaló (különböző társadalomföldrajzi és természetföldrajzi megközelítéseket is felhasználó) tanulmány is készült Szilágyi (2009). Összességében elmondható, hogy településföldrajzi és a néprajzi tájértelmezés között csekély az eltérés, ezzel szemben a természetföldrajzi meghatározások már lényeges különbségeket mutatnak (2.8. ábra). Ennek oka, hogy a természetföldrajzi megközelítéssel készült lehatárolások (pl. Magyarország kistájainak kataszterében megtalálható felosztás Marosi Somogyi szerk.1990) napjaink természetföldrajzi állapotára épül, ezért csak csekély részben fedi a hajdani/történeti Sárrét (egykori mocsár) területét. Így a tradicionálisan definiált kistájak felosztásában Sárrét elnevezés, már nem „pontos”. A tanulmány eredményéül megszületetett egy új Sárrét lehatárolás a területre eső települések tulajdonságainak vizsgálatai alapján. 


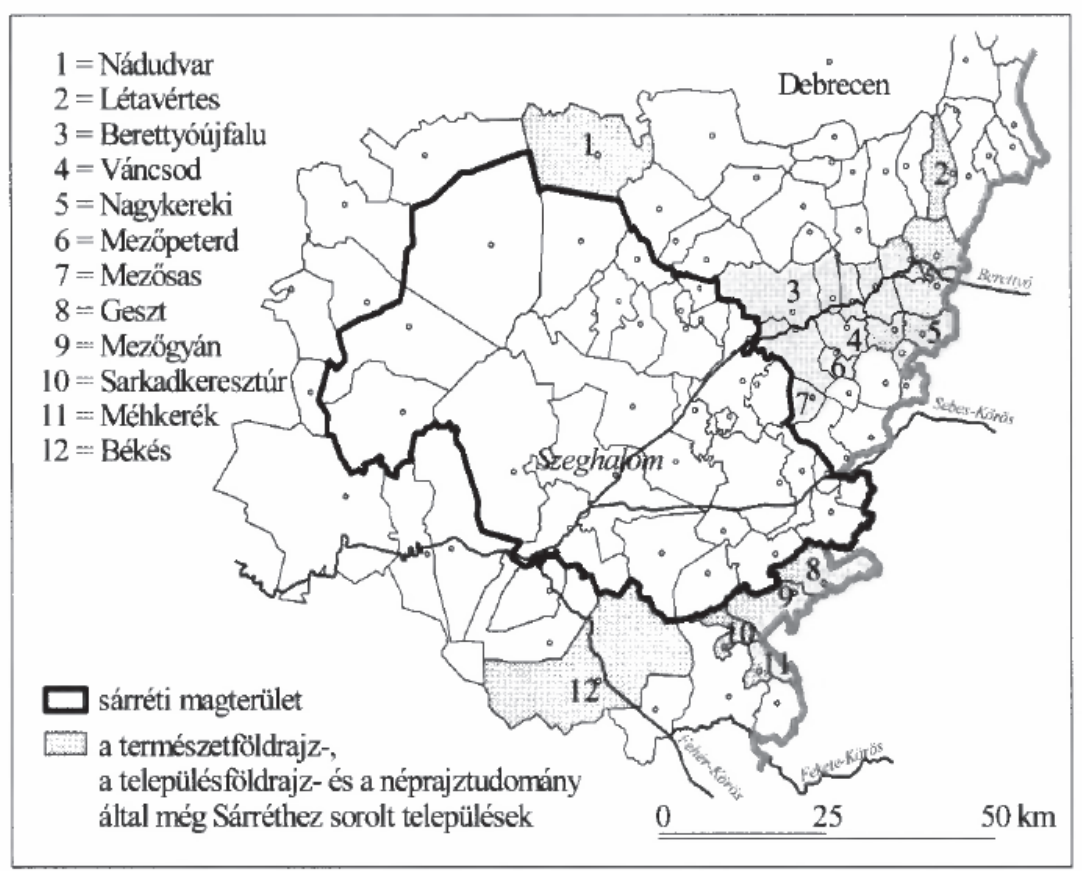

2.8. ábra: Sárréti települések a természetföldrajz, a településföldrajz és a néprajztudomány szerint (Szilágyi 2009)

c, Ugyancsak többen foglalkoztak az Érmelléki löszös hát kistáj pontosabb, föként társadalomföldrajzos megközelítésű lehatárolásával (Benedek 1996, Flórián 2008), Az Érmelléki löszös hát kistáj módosított határának kialakításához egyaránt figyelembe vették a gazdasági kapcsolatokat, település elnevezéseket (Ér előtagú település nevek), illetve a természetföldrajzi határokat (2.9. ábra).

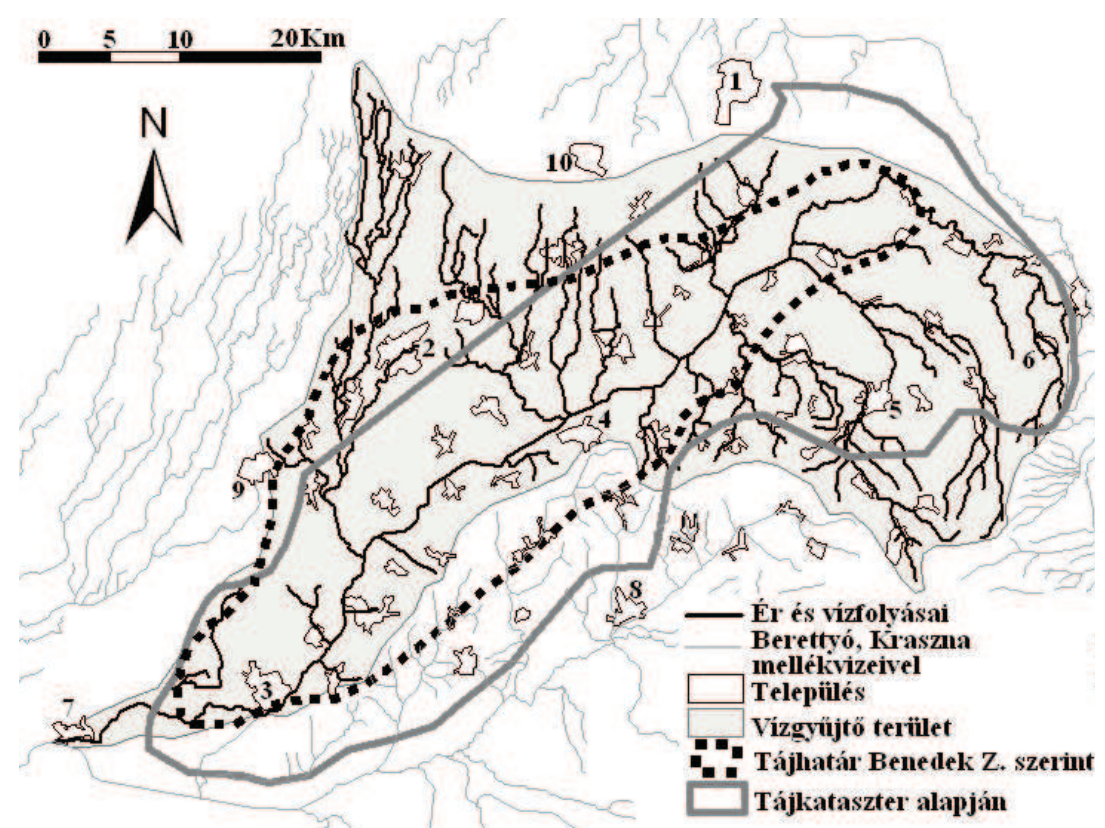

2.9. ábra: Az Érmelléki löszös hát lehatárolása:1. Nagykároly (Carei), 2. Érmihályfalva (Valea lui Mihai), 3. Bihardiószeg (Diosig), 4. Szalacs (Sălacea), 5. Tasnád (Tăşnad), 6. Újnémet (Unimăt), 7. Pocsaj, 8. Margitta (Marghita), 9. Bagamér, 10. Szaniszló (Sanislau) (Flórián 2008) 
d, Továbbá részletesen foglalkoztak az Illancs kistáj területhasználati -, domborzati-, talaj - és növényzetborítási tulajdonságok vizsgálata során a kistáj határának pontatlanságáról (Ladányi 2010). A kutatás egyik eredményéül a terepbejárások gyüjtött észrevételek, adatok, a felszíni üledékek és a területhasználat figyelembevételével elkészült az újabb, pontosabb Illancs kistáj lehatárolása, mely a 2.10. ábrán látható (Ladányi (2010).

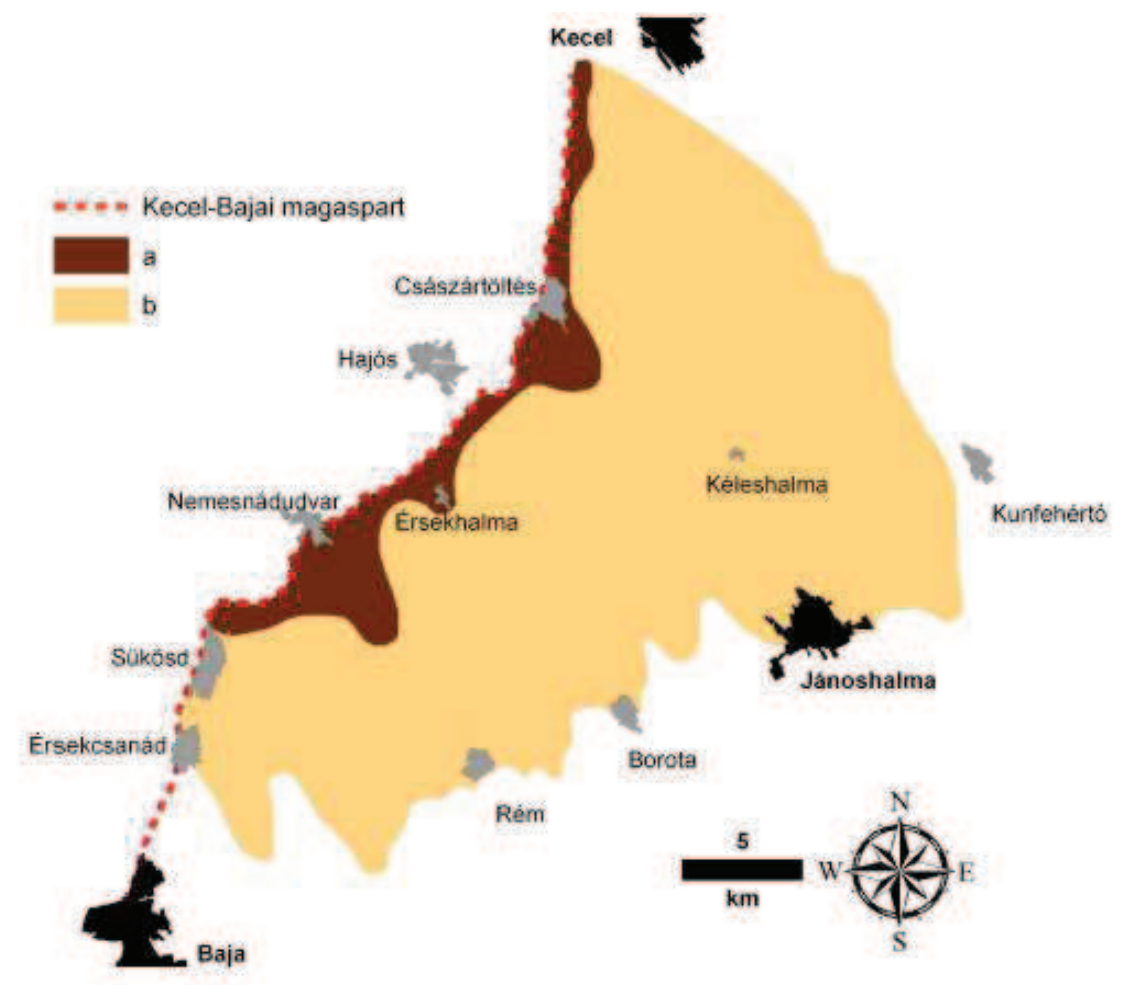

2.10. ábra: Az Illancs, mint kistájcsoport a módosított határvonalak alapján: aNemesnádudvar-Császártöltési löszhát, b-Illancsi homokhát (Ladányi 2010)

e, Komplex tájökológiai kutatásokat követően Deák (2010) tájhatár módosítási javaslatokat tett (2.11. ábra) Csongrád megye területére. Az elkészített tájökológiai kapcsolatrendszerek értékeléséhez és a tájlehatároláshoz többek között vizsgálta a területre jellemező geológiai adottságokat (felszíni üledékek), geomorfológiai, illetve talaj tulajdonságokat (felszínalaktani formák, talajföldrajzi mintázatok), élőhelyek elterjedését (saját élőhelytérképezés alapján). 


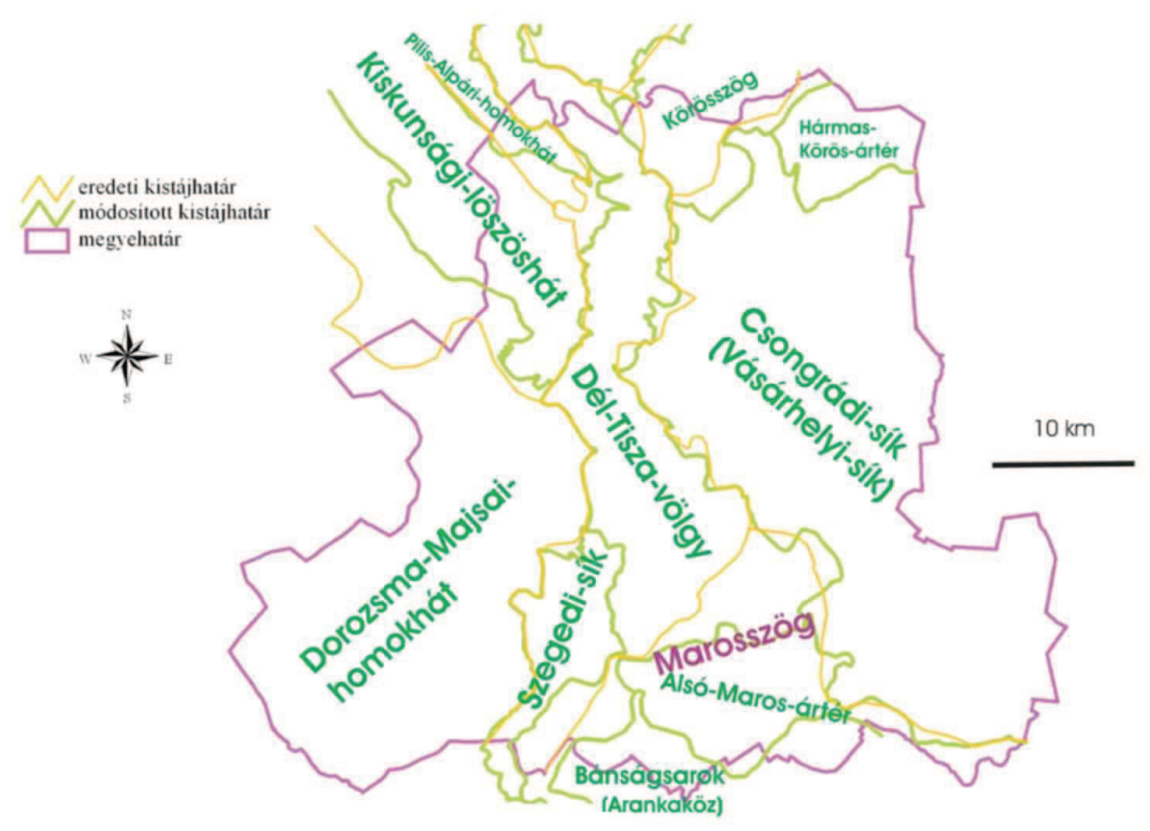

2.11. ábra: Csongrád megye eredeti és módosított kistájbeosztása (Deák 2010)

f. A tájlehatárolás problematikus azokon a területeken, ahol az érintkező tájaknak az értelmezése, sőt megnevezése is nehéz. Ilyen területek pl. azok a tájak, melyek több évszázada rögzült népi nevekkel illetnek, viszont azok mellett „nevesincs" vidékek találhatóak. Ezek a nevén nem nevezett tájak csak későbbi kutatások (Pécsi - Somogyi 1967) eredményeként született meg. Ez a helyzet a Nyírség és a Hajdúhát és a Nyírség és a Hajdúság esetében is (Lóki - Szabó 2006, Pénzes 2009). A Nyírség határának meghúzása, a tradicionális definiált csoportba sorolható, Ny-i szomszéd kistájának elkülönítése nem természeti viszonyokra épült. A Hortobágy és a Hajdúhát kistájak területén a domborzat észrevehető magasságkülönbség nélkül megy át egymásba, földtani felépítésük is hasonló, ezért a Hajdúhát Ny-i oldalán mintegy 20 m magas, tereplépcső jellegü lejtőt tekintették éles és egyértelmủ tájhatárnak (Pécsi - Somogyi 1967). A földtani feltárások rétegeinek elemzése (Lóki - Szabó 2006) megerősítette azt a korábbi véleményt, hogy a két táj határsávjában a folyóvízi, futóhomok és löszös üledékek mind horizontálisan, mind vertikálisan nagyon változatosan jelentkeznek a területen. Vagyis tájhatár egyértelmü kijelölése még ott is bonyolult, ahol a felszíni morfológia alapján egyértelműnek tünik (Pénzes 2009).

Az egyes módosítási javaslatokban felsorolt - sokszor más és más módszert és vizsgálati kulcsparamétereket alkalmazó- vizsgálatok nehezen, sok időt felemésztve lennének csak elvégezhetőek Magyarország teljes területre annak érdekében, hogy minden kistáj határát a fent említett módszerekkel egyenként pontosítsuk, újrarajzoljuk a tradicionálisan definiált tájfelosztáshoz képest. 


\section{Alkalmazott kutatási módszerek}

A tájak határainak értelmezésére, definiálására megítélésem szerint kétféle megközelítési lehetőség kínálkozik:

Egyrészt elfogadva, hogy a tájak létező objektumok, azok határa a tájalkotó tényezők tulajdonságainak felhasználásával „merev” vonalként meghúzható. A tájak határainak megvonásának egyik szükséges előfeltétele azonban az objektivitás. Ebben az esetben a matematikai-statisztikai módszerekkel definiált lehatárolás elkészítéséhez különféle szegmentációs módszerek (mint pl. a többváltozós szegmentáció) alkalmazhatóak.

A másik megközelítési mód szerint, viszont a tájat felépítő tájalkotó tényezők elemei, típusai a térben eltérő, határuk nem éles (nem „merev” vonal), illetve az egyes tényezők időben eltérő sebességgel változnak, így a határt ökotonként célszerü kezelnünk. Ekkor a határok értelmezése a fuzzy logikával releváns módszernek tűnik.

\subsection{A táj lehatárolása objektív szegmentációval}

A tájak határait (kevésbé figyelve azok tartalmát) a „gyakorlatban” általában („merev”) vonalként kezeljük. Igényelhető azonban, hogy a tájak határainak megvonása tudományosan megalapozott legyen. Ha több tényező figyelembevételével határozzuk meg a határvonalak helyzetét, akkor egyrészt elvárt, hogy a több tényező együttes elemzésében az integrálás és a lehatárolás megismételhető, és hasznosnak tünik, hogy a folyamat „semleges”, objektív, matematikai-statisztikai összefüggésekkel leírható legyen.

A határok vonalként történő kezelése esetén azokat matematikailag, a Boole algebra szerinti halmazelméletben a vagy logikai összefüggéssel írhatjuk le. Eszerint egy elem (egy adott pont a térben) vagy az egyik vagy a másik halmazhoz (tájhoz) tartozik. Vagyis a két táj közötti határ egy vonal. Ezen megközelítés szükségességét az adja, hogy a „gyakorlatban” a területi tervezés során a tájtervező munkája során „merev” vonalakat kell húznia, ezért ilyen jól definiált vonalszerü határokkal jellemezhető input adatokat is vár el, pl. a tájak határait illetően (Csorba 2008).

A tájtervezők és azon tájkutatók, akik regionális kutatási és/vagy tervezési feladataikhoz szükségük van az adott kistáj, középtáj határának elhelyezkedésének ismeretére, ,jobb híján” a Magyarországon ismert és elfogadott kistájkataszterben (Marosi - Somogyi szerk. 1990) részletesen bemutatott tájfelosztási térképét alkalmazzák (Kerényi 2007). 
A következőekben a tájlehatárolás létrehozásakor egy, az általam alkalmazott módszerét szeretném bemutatni. A módszer a „merev” tájhatár értelmezési elképzelésen alapul, célja hogy a lehatárolás objektív és bármikor - ugyanolyan eredményre jutóan - megismételhető legyen.

\subsubsection{Szegmentációs módszerek}

A tájak határainak, mint „merev” vonalak meghúzására, táji egységek elkülönítésére kétféle módszer kínálkozik (3.1. ábra): az objektív és a szubjektív lehatárolás (továbbiakban: szegmentáció).

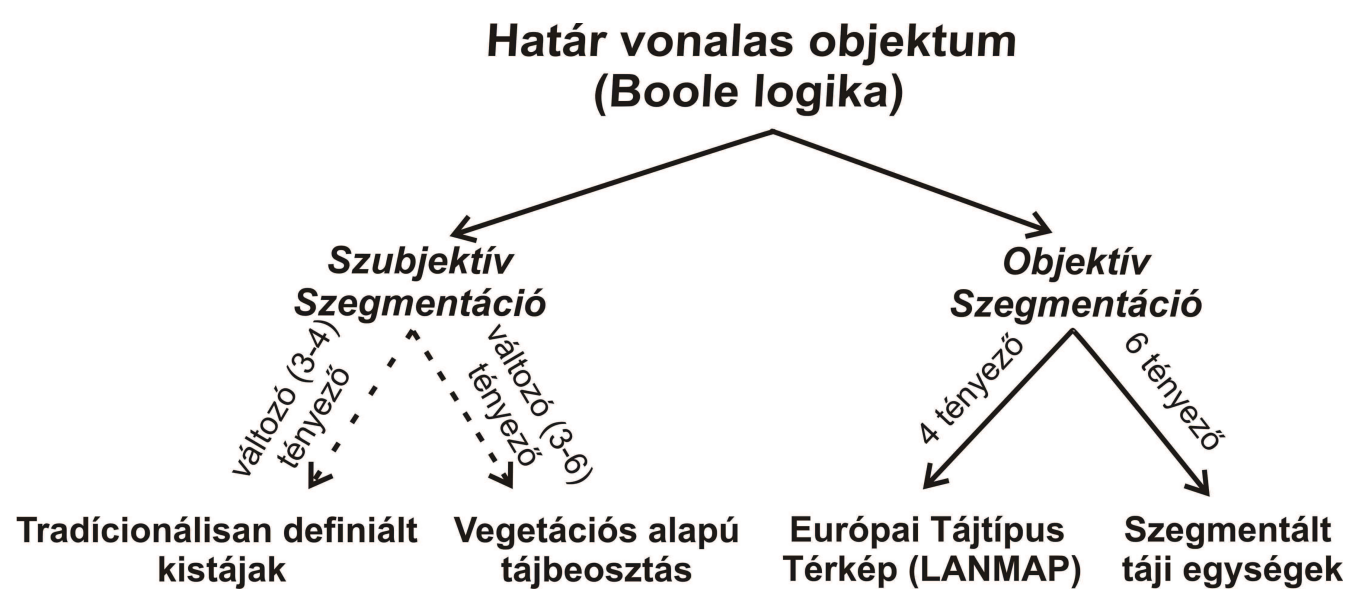

3.1. ábra: A táji egységek lehatárolási módszerei Magyarországon (Bata et al. 2013)

a, Szubjektív szegmentáció:

A szegmentációs folyamatban nagy hangsúlyt kap az emberi tudás, ismeret, tapasztalat az adott tájról. Ugyanis nem egy előre definiált statisztikai, matematikai szegmentálási szabály szerint történik a lehatárolás, így a szegmentáció szubjektív. Mivel a figyelembe vett ismeretek, tapasztalatok nem egyértelműen matematikailag definiáltak, ezért a szegmentálás folyamata nem megismételhető, nem automatikus. A tradicionálisan definiált kistájak (Marosi - Somogyi szerk. 1990) és a vegetációs alapú tájbeosztás (Molnár et al. 2008) egységeit is ezzel a logikával, szubjektív szegmentáció alapján határolták le (Bata et al. 2013). 


\section{b, Objektív szegmentáció:}

Ekkor egy automatizált folyamatban, a táj felosztása, lehatárolása előre definiált matematikai-statisztikai szabályok alkalmazása szerint történik. A folyamatra nincs hatással egy-egy táj részletesebb, főként szubjektív megítélése, a szegmentáció objektív és így bármikor ugyanolyan eredményre jutóan megismételhető. Az Európai Tájtípus térkép (European Landscape Topology and Map - LANMAP -Mücher et al. 2010) egységeit is objektív szegmentációval határolták le.

Célom, hogy ezen objektív szegmentáció alkalmazásával készítsek el egy közepes méretarányú tájlehatárolást (dolgozatom további részében az objektiv lehatárolás eredményét „,szegmentált táji egységek”-nek hívom). A lehatároláshoz felhasznált tényezők többségükben (egy kivételével) természeti tájalkotó tényezők ( $l s d$. 4. Vizsgált terület, adatok fejezet), így az eredményül kapott közepes méretarányú szegmentált természeti (táji) egységek, nem pedig tájak.

\subsubsection{Az alkalmazott többváltozós szegmentáció}

A képszegmentációs módszereket az 1970-es években dolgozták ki (Haralick et al. 1973, Haralick - Shapiro 1985). Kezdetben ezeket a szegmentációs eljárásokat főként a távérzékelt (spektrális) adatok szegmentálására és osztályozására használták (Burnett - Blaschke 2003, Haralick - Shapiro 1985, Ryherd - Woodcock 1996, Baatz - Schäpe 2000, Bock et al. 2005, Boutin et al. 2008, Lucas et al. 2011), de a módszer alkalmazható vektoros adatok felhasználásával is (Mücher et al. 2010, Renetzeder et al. 2010).

Az elmúlt évtizedben a föltudományok különböző területein több új szegmentációs algoritmust és azok alkalmazásait tesztelték, de a pixel alapú elemzéseket gyakran kritizálták, Blaschke - Strobl (2001), Burnett - Blaschke (2003) részletesen kifejttette ezek hibáit. Az objektum alapú képi elemzések (OBIA) alkalmazhatóak a táji elemzésekben is, ezek eljárások a pixelosztályozás mellett figyelembe veszik a szegmentált egységek, objektumok nagyságát, formáját és helyzetét is (Blaschke - Strobl 2001, Drăgut - Blashke 2006).

A többváltozós szegmentáció (multiresolution segmentation) egy optimalizált, objektum alapú, objektív szegmentációs eljárás, mely a lehatárolandó szegmenten belül az összes bemeneti adatot felhasználva egyrészt minimalizálja az átlagos heterogenitást és maximalizálja a viszonylagos homogenitást a lehatárolt folton belül. Ez a módszer nem oldja meg az adatok integrálásának kérdését, de kezeli a probléma komplexitását azzal, hogy több 
bemeneti adatot képes egyszerre kezelni az előre definiált szabályrendszer alkalmazása mellett (pl. méretarány, kompaktsági érték megadása).

Az Európai Tájtípus Térkép (LANMAP) (ELCAI 2005) is ilyen szegmentációval készült, viszont csak négy tényező, a kőzet, talaj, klíma és területhasználat térképeinek felhasználásával (Mücher et al. 2010). A LANMAP által bemutatott tájak nem alkalmasak a regionális kutatások alapjaként, mivel a térkép térbeli felbontása $1 \mathrm{~km}$-es, így a létrehozott táji egységek határai elnagyoltak, nagymértékben generalizáltak (Mezősi et al. 2012, Bata et al. 2013). Ezért célom volt egyrészt nagyobb térbeli felbontás mellett (100 m) a többváltozós szegmentáció futtatása több, a vizsgált összes (6) tájalkotó tényező bevonásával (A módszer a hat tényezöt egyszerre, egy hatsávos spektrális képhez hasonlóan kezeli). A térbeli felbontás nagyságát, az alapadatok felbontása, az SRTM adatok 90 x 90 m-es felbontása határozta meg, az adatveszteség, generalizálás elkerülése végett.

A többváltozós szegmentációs folyamata a „kölcsönösen legjobb illeszkedés szabálya” (mutual best-fitting rule) szerint hajtja végre a kép szegmentációját. A folyamat lépései:

1. A szegmentációs folyamat egy rétegének egy pixelével kezdődik. A pixelek összevonása egy nagyobb szegmenssé addig történik, amíg az összevonás el nem éri - az előre definiált- megengedett homogenitás felső határértékét. Ez a homogenitási kritériumot a spektrális- és alak homogenitás határozza meg, a kritériumot a „,skála” (scale) paraméter változtatásával módosíthatjuk (3.2. a, ábra A).

2. A pixelösszevonás folyamata addig tart, míg a pixel a legközelebbi szomszéd elve alapján meg nem találja az összes potenciálisan egy szegmenshez tartozó párjait (3.2. a, ábra $\mathrm{B}$ és C).

3. Ha egy pixel már nem tartozik az előbb említett szegmenshez a tulajdonságai alapján, akkor ezzel a pixellel új legközelebbi szomszéd elve alapján keresés indul az előre definiált homogenitási kritérium betartásával (1-2 pont). A keresési folyamat addig fut, míg az összes pixel nem osztályozódik valamelyik szegmenshez (3.2. a, ábra D).

4. A folyamat a többi réteg pixel- tulajdonságainak vizsgálatával folytatódik, az iteráció addig fut, míg további új szegmens elkülönítése már nem lehetséges (3.2. b, ábra), vagyis nem történik pixelösszevonás anélkül, hogy a szegmensen belül maximálisan megengedett homogenitási értéket túllépné (Trimble 2011). 


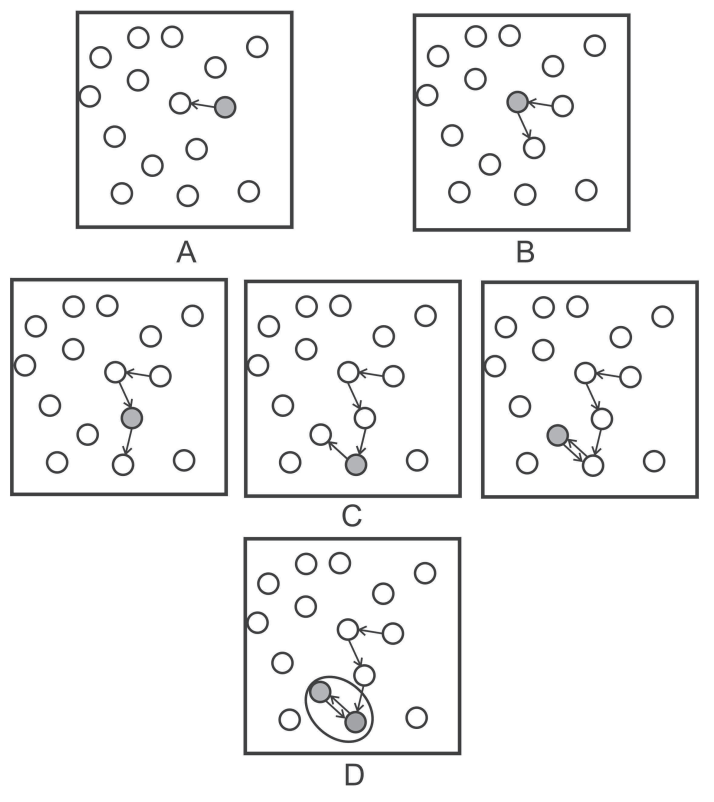

3.2. a, ábra

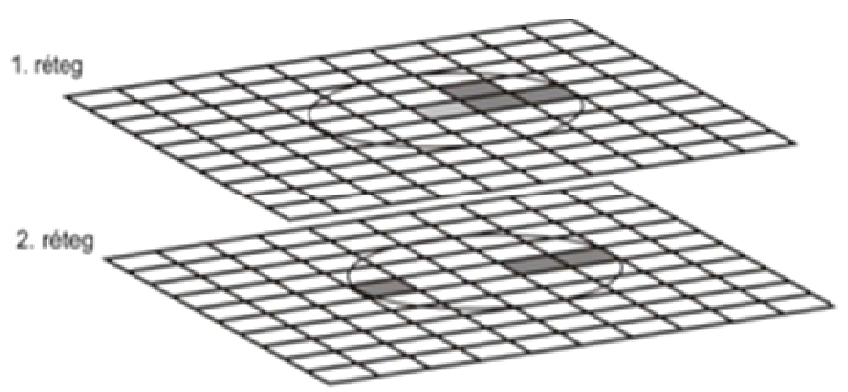

Eredmény

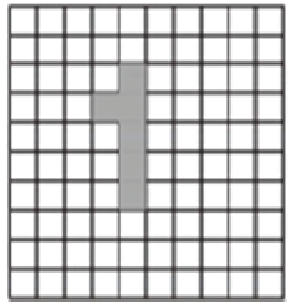

3.2. b, ábra

3.2. a, és b, ábra: A szegmentálás folyamatának lépései Trimble (2011) alapján

A Többváltozós szegmentáció futtatásakor három kulcs paramétert kell megadnunk: „,skála” (scale), ,alak” (shape), és „tömörség” (compactness) paramétereket (Trimble 2011). A három paraméter az alábbi tulajdonságokat határozzák meg (3.3. ábra):

- Skála (scale): meghatározza a megengedett maximális homogenitást a szegmensen belül. Adott érték megadásánál egy heterogénebb területen kisebb lesz a folt mérete, mint egy homogénebb területen. Az érték változtatásával módosítjuk a szegmentált folt méretét.

- Alak (shape): az alak és a szín kritériumok közti kapcsolatot határozza meg. Ha csökkentjük az értékét, a szegmentáció a bemeneti raszter képek spektrális tulajdonságait (szín) nagyobb hangsúllyal veszi figyelembe és kevésbé a raszter képek pixeleinek textúráját (alak).

- Tömörség (compactness): a szegmentált foltok tömörségének megadására szolgál (Megjegyzés: a „símaság” (smoothness) értéke: 1- tömörség értéke). 


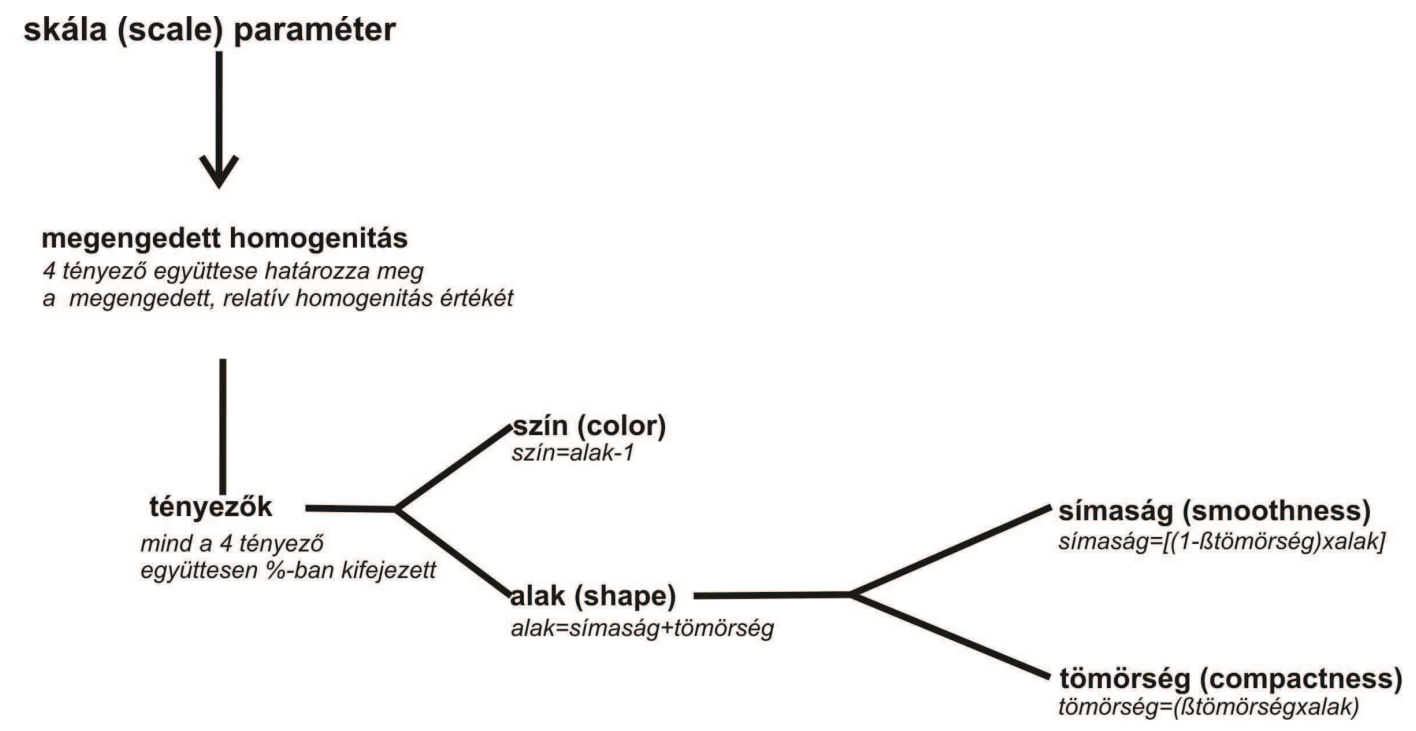

3.3. ábra: A többváltozós szegmentáció tényezői Trimble (2011) alapján

A „skála” paraméter miatt, mivel előre nem ismert, hogy mely beállítással szegmentálhatunk közepes méretarányú táji egységeket, így 50-es értékbeállítástól kezdődően 10-es különbséggel 400-ig növeltem ezt az értéket. Annak érdekében, hogy a szegmentálás során kizárólag a raszteres térképek spektrális tulajdonságait, vagyis a tájalkotó tényezők típusainak térbeli mintázatát vegye figyelembe az eljárás, ezért az „alak” paramétert a legmagasabb 0,9-es értékre állítottam be. Elkerülve azt, hogy elöre definiált legyen a szegmentált táji egységek tömörsége, a „,tömörség” paramétert, a semlegesnek tekintett 0,5-es értékre állítottam.

Az így szegmentált táji egységeket elsőként a tradicionálisan definiált kistájainkkal hasonlítottam, össze, mégpedig FRAGSTATS szoftverben a különböző tájmetriai mutatók kiszámításával (McGarigal - Marks 1995). A kiszámolt tájmetriai mérőszámok jól alkalmazhatóak a táji egységek természetességének (Herzog et al. 2001, Zebisch et al. 2004, Wrbka et al. 2004, Winter - Fischer 2010, Szilassi - Bata 2012) és a tájak érzékenységének vizsgálatára (Mas et al. 2010).

A táj természetességével kapcsolatban áll a „Legnagyobb folt mérete” (Largest Patch=LP), a „Legkisebb folt mérete” (Smallest Patch=SP), a „Foltok száma” (Number of Patches=NP), az „Átlagos foltméret” (Mean Patch Size=MPS) és a „Fraktáldimenzió átlaga” (Mean Fractal dimension =MFRACT). A „Fraktáldimenzió” a foltok alakjának összetettségét kiterjedésük (méretük) figyelembe vételével fogja meg. Értéke 1-2 között változik. 1 a 
legegyszerübb formák esetében, a komplexebb formák „,Fraktáldimenzió” értéke közelíti meg a 2-öt (McGarigal - Marks 1995, Szabó 2009).

A kiszámolt érzékenységet mutató tájmetriai mérőszámok a következők voltak: „Foltonkénti határhossz” átlaga, „Magterületi index” és az átlagos „Alaki index”. A „Magterületi index” egy adott méretü (jelen esetben $2 \mathrm{~km}$-es) szegélyzónával számított „mag” területét fejezi ki százalékos formában. Értéke 0, ha nincs belső terület (mag), és megközelíti a 100-at, ha a belső terület maximális kiterjedésű, azaz kör alakú. „,Alaki index” értékét megkapjuk, ha a folt kerületét elosztjuk a minimumkerülettel, amit egy ugyanolyan területre vonatkoztatott kompakt folt (kör vagy négyzet) kerületeként határozzuk meg (McGarigal - Marks 1995, Szabó 2009).

A tradicionális megközelítéssel végzett lehatárolás (Marosi - Somogyi szerk. 1990) egy szubjektív szegmentáció eredménye. Ebben a szegmentációban a térrészek kistájakba történő integrálása különbözik az síkvidéki és hegyvidéki területeken. Ennek egyik példája, hogy a síkvidéki területeken $(0,0$ - 200,0 m) a lehatárolás során a közép - és kistájak határai főként a talajtípusok határaihoz és a természetes vegetáció határaihoz illeszkednek, a dombvidéki $(200,1-500,0 \mathrm{~m})$ és a hegyvidéki területeken $(>500,0 \mathrm{~m})$ a geológiai, domborzati és területhasználati tényezők voltak a kulcs paraméterek. Ezért célom volt ezen orográfiai kategóriák oldaláról is összehasonlítani a szegmentált táji egységeket és a tradicionálisan definiált kistájakat.

\subsection{A táj kiterjedésének elemzése fuzzy logikával}

A tájak határait ökotonként is kezelhetjük (sőt a tájökológia alapvetően így is kezeli). E megközelítés alapját az adja, hogy a tájakat formáló, kialakító tájalkotó tényezők térben és időben folyamatosan változnak (Csorba 2008). A tájak, és a tájalkotó tényezők határai nem egy vonalhoz illeszkednek, amelyet persze nem is várhatunk, mert többnyire maguk a tényezők sem határolhatók éles vonalakkal. Példaként, ha a talajtényezőt vesszük alapul, éles vonallal nem lehet berajzolni a csernozjom - és a homoktalajok határát (Barta et al. 2012).

Általában a litológiai, a domborzati, a talajtani, vagy a vegetáció határok még nagytáj szinten sem illeszkednek szigorúan (3.4. ábra), noha egymáshoz kapcsolódásuk törvényszerüsége ismert (pl. a litológia és a talaj kapcsolata). A határ szempontjából azonban a tájalkotó tényezők közötti, vagy a tájalkotó tényezők és táj ökológiai egységei közötti kapcsolatok pontos feltárása még többnyire megoldásra vár. Az alkalmas adatmennyiség 
szükössége miatt itt inkább tapasztalati, mint statisztikai módszerek használhatóak. Lényeges szakmai feladat lehet pl. annak tisztázása, hogy a domborzat milyen mértékben jelzi előre a táj mozaikosságát (Lóczy D. 2002).

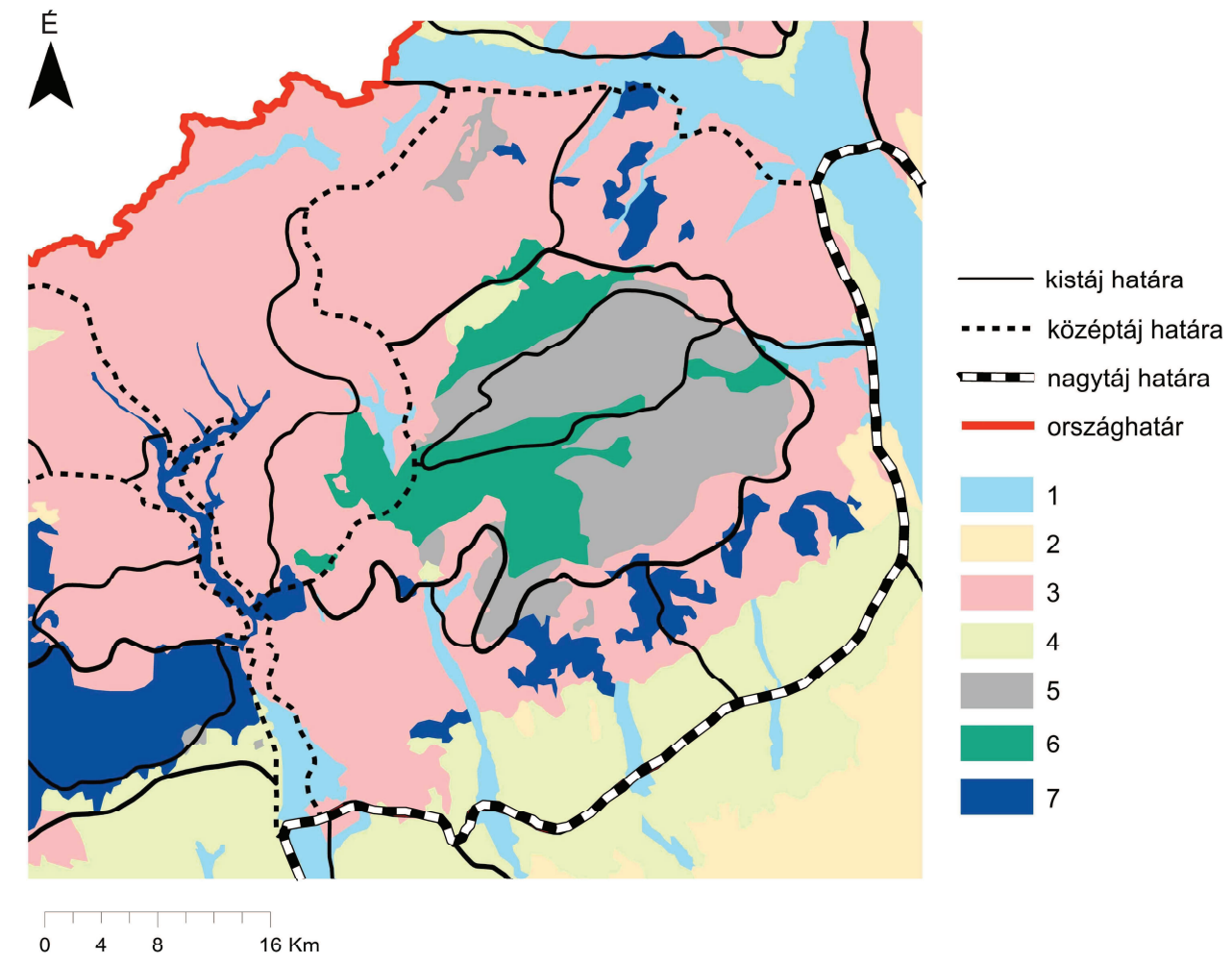

3.4. ábra: A tájhatárok és a litológia (talajképző kőzet) határai a Mátrában: 1-alluviális üledékek, 2-löszös üledékek, 3-harmadkori és idősebb laza üledékek,4-nyirok, 5-mészkő, dolomit, 6-agyagpala, fillit, 7-vulkáni kőzetek (MNA 1989 alapján)

Mindezek alapján az egyik táj finomabban, „merev” határ nélkül megy át a másikba. Ebben a táj megközelítésben alkalmasnak tünő módszer a fuzzy logika gyakorlati alkalmazása, mely matematikailag pontosan definiálható (Mezősi-Bata 2011/a, Bata et al. 2013). Ezt a módszert alkalmaztam a dolgozatomban bemutatott elemzésekre.

\subsubsection{A fuzzy logika}

A fuzzy „lágy halmazok” fogalmát Zadeh 1965-ben vezette be (Borgulya 1998). A fuzzy logika szerint az alaphalmaz minden eleméhez a rögzített tartományból: $[0,1]$ rendelhetö érték. Ezen érték nagysága a halmazbeli tagság mértékével arányos, azaz minél nagyobb (kisebb) mértékben tagja a halmaznak az elem, annál nagyobb (kisebb) az elemre vonatkozó függvényérték. Ezt a függvényt tagsági függvénynek, az általa definiált halmazt fuzzy halmaznak nevezzük (Kóczy - Tikk 2000). 
A fuzzy logika szerint egy halmaz határa nem egy éles vonal, hanem a két szomszédos halmaz fokozatosan megy át egymásba.

Az egyik leggyakrabban bemutatott eset a fuzzy halmazok szemléletesére az emberi magasság fuzzy logika szerinti értelmezése:

Ebben a bemutatott esetben három fuzzy halmaz létezik:

- A halmaz $=\{$ alacsony termetü emberek $\}$

- $\quad$ B halmaz $=\{$ középtermetü emberek $\}$

- $\quad \mathbf{C}$ halmaz $=\{$ magas termetü emberek $\}$

Tegyük fel, hogy egyik alanyunk (1. alany) $157 \mathrm{~cm}$, a másik (2. alany) $185 \mathrm{~cm}$ magas. A fuzzy logika alkalmazásakor minden ember egyértelmüen besorolható magassága alapján a három halmazba, mégpedig:

$\mathrm{Az}$ 3.5. ábrán bemutatott tagsági függvény szerint, 1. alanyunk 100\%-ban tartozik az A halmazhoz, 0\%-ban a B és $\mathbf{C}$ halmazokhoz. 2. alanyunk 0\%-ban tarozik az $\mathbf{A}$ halmazhoz, 50\%-ban a $\mathbf{B}$ - és 50\%-ban a $\mathbf{C}$ halmazhoz, vagyis az A- és a B- illetve B- és $\mathbf{C}$ halmazok közötti határ nem éles, nem egy adott magassági érték, hanem a halmazok fokozatosan mennek át egymásba.

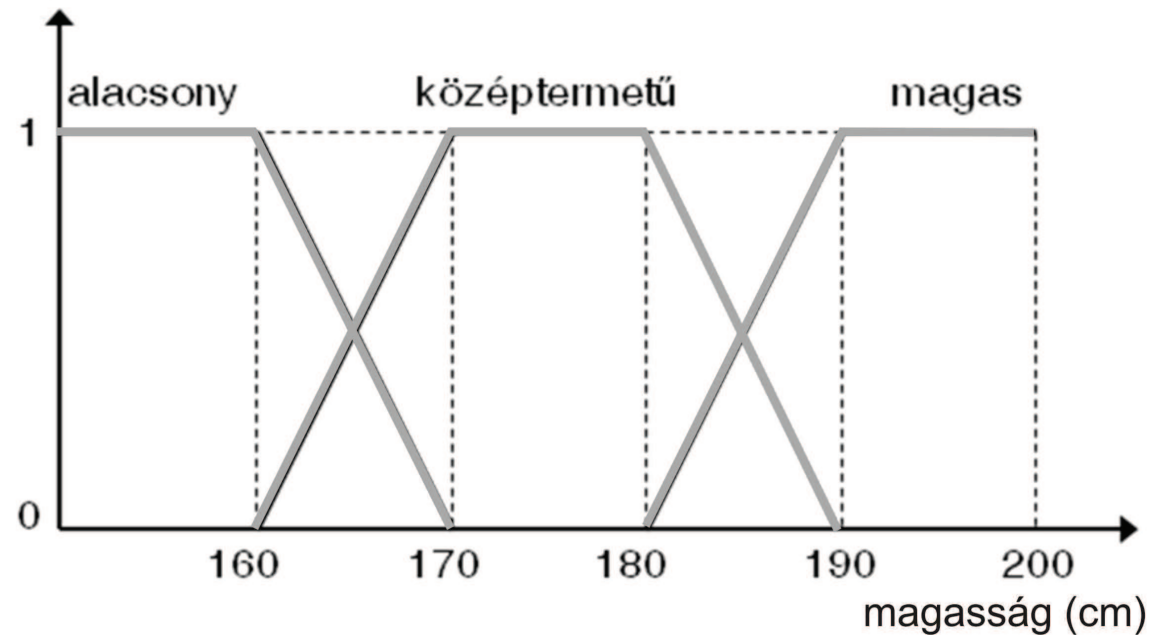

3.5. ábra Az emberi magasság fuzzy logika szerinti értelmezése (Kóczy - Tikk 2000 alapján) 


\subsubsection{A fuzzy logika földrajzi alkalmazásai}

Az 1990-es évek végén a Földrajzi Információs Rendszerek (angolul GIS) fejlődésével megkezdődött a fuzzy logika gyakorlati használata a földtudományokban is. McBratney Odeh (1997) a „lágy” halmazok elvét a talajok mélység szerinti osztályozására alkalmazta (3.6. ábra).

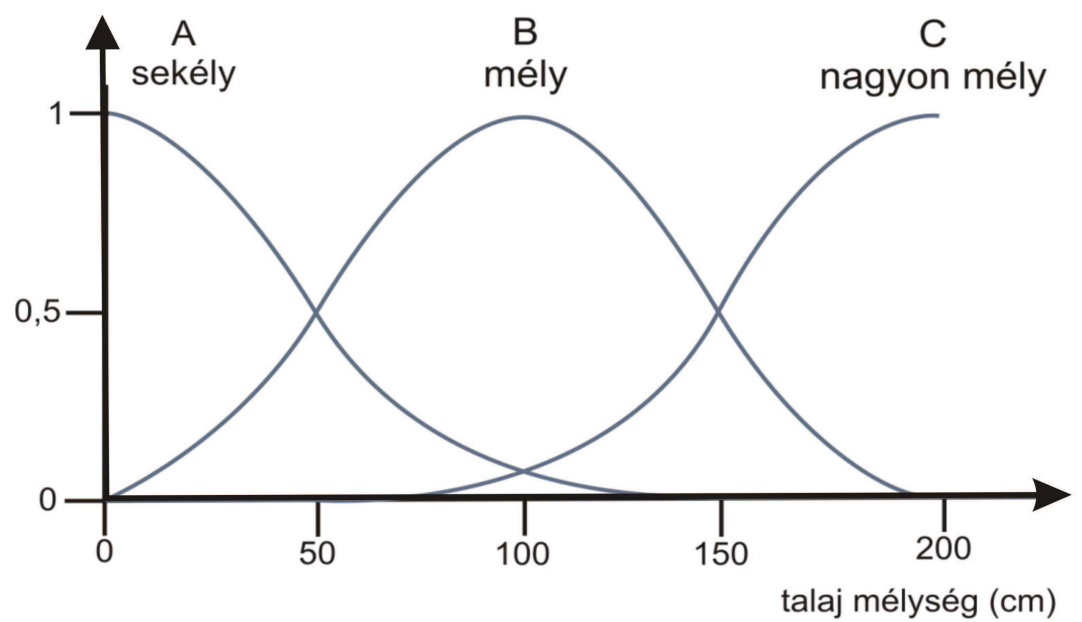

3.6. ábra: A talajok mélység szerinti osztályozása a fuzzy logika alapján (McBratney Odeh 1997 alapján Mezősi-Bata 2011/a).

A fuzzy logika a talajok mélység szerinti osztályozás mellett megfelelően alkalmazható a földértékelésben, a talajok fizikai tulajdonságainak modellezésében, a bennük ható folyamatok szimulációjára is. A talajtan mellett pl. az úttól való távolság alapján a megfelelö terület osztályozásánál a „közeli”, „átlagos” és „távoli” területek elkülönítésére (3.7. ábra) (McBratney - Odeh 1997).

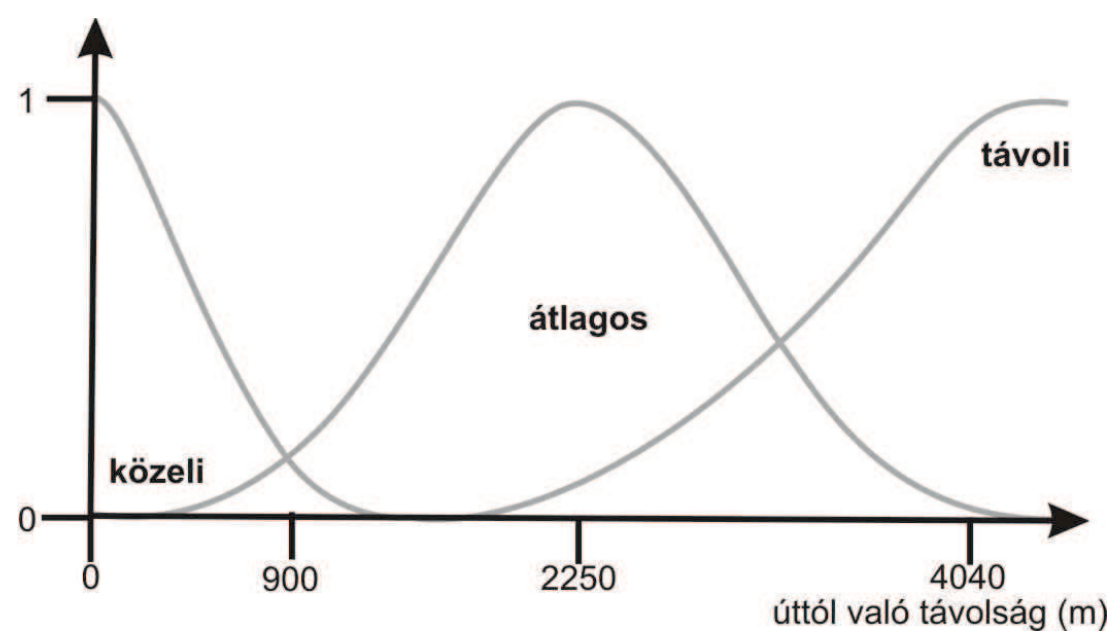

3.7. ábra: Terület osztályozása fuzzy logikával az úttól való távolság alapján (McBratney Odeh 1997 alapján) 
A fuzzy logika egy olyan utat ajánl az elemzésekben, mellyel a való világot és a való világ folyamatait valósághủen képes kezelni (Mezősi et al. 2013). Ezen logika szerint a tájakat is tekinthetjük „lágy” halmazokként, hiszen, mint korábban említettem a tájalkotó tényezők határai sem állandóak, térben és idöben is folyamatosan változnak. Az ökotonok fuzzy logikájú elemzésével (nagytáji méretarányban) Arnot és Fisher (2007) foglalkozik, de esetemben a feladat nem a határok megvonása, hanem az ökotonok azonosítása és azok méretének megállapítása volt a tradicionálisan definiált kistájakhoz illeszkedően.

\subsubsection{Az, alkalmazott fuzzy tagsági függvény}

Az elemzésben a kis-és a középtájak léptékéhez illeszkedően 1:100 000 méretarányban öt természeti tényező (talaj, talajképző kőzet, növényzet, vízgazdálkodás, domborzat) közel azonos számú típusát és egy tényezőként az antropogén hatást jellemző hemeróbia szintjeit használtam fel (Bata et al. 2013).

A fuzzy elemzésben mind a hat tényezőre elkészített, a 4. Vizsgált terület, adatok fejezetben bemutatott homogenitási adatokkal dolgoztam. Azért a homogenitási adatokkal (1sd. 8. - 13. sz. mellékletek), mert egyrészt a fuzzy elemzések egységes numerikus bemeneti adatot követelnek meg, másrészt ebben a megközelítésben nem kellett számolnom a vizsgálatnál a tájalkotó tényezők prioritási sorrendjének és súlyozásuknak a problémájával. Ezekre a homogenitási térképekre a fuzzy elemzést az IDRISI Taiga szoftverrel végeztem el (Clark Labs 2011).

Az általam használt fuzzy tagsági függvényt mutatja be a 3.8. ábra. A fuzzy halmazoknál alkalmazott számítás úgy írható le, hogy:

- a 30 \% homogenitási értéknél kevesebb értékü területek a határzónák (ökoton) halmazába kerülnek (ezek az eredménytérképen 1 értékkel jelennek meg),

- a 70 \% homogenitási értéknél nagyobb értékű területek a homogén táji magok halmazába kerülnek (ezek az eredménytérképen 0 értékkel jelennek meg), míg

- az ezektől eltérő homogenitási értékű területek olyan új értéket kapnak, amely azt mutatja, hogy a terület hány százalékban tartozik az ökoton területhez, illetve a táji magok halmazához (ezeket akár nevezhetjük átmeneti területeknek is). 


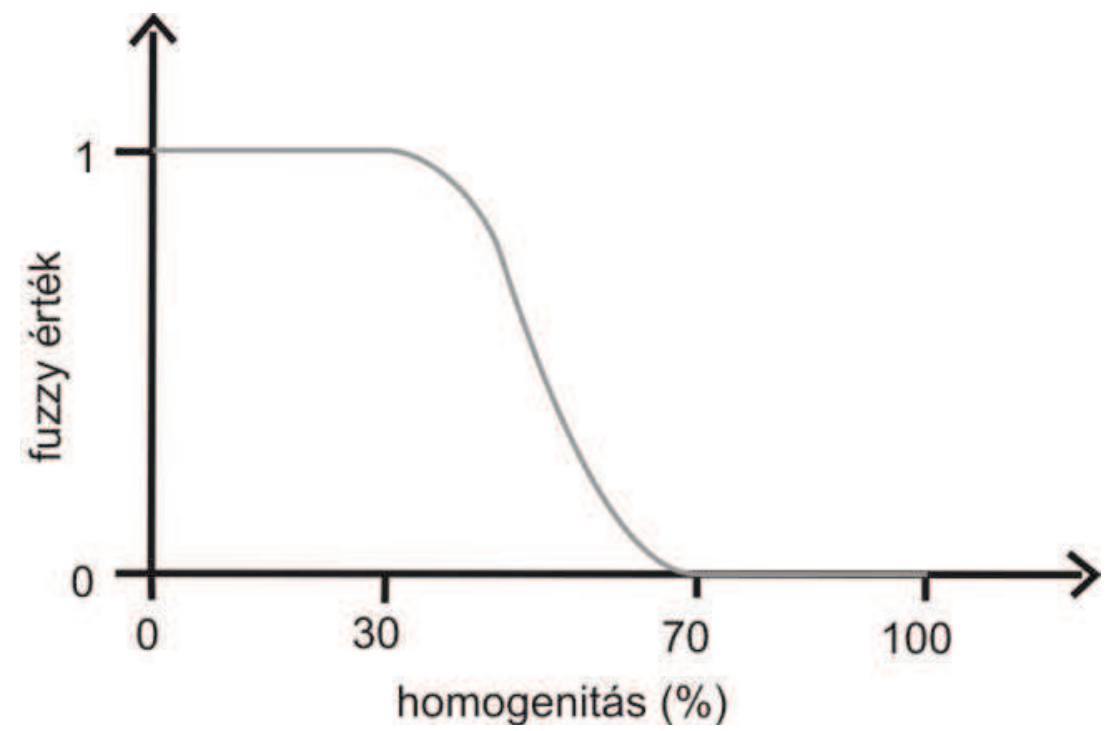

3.8. ábra: A tájalkotó tényezőknél alkalmazott fuzzy tagsági függvény képe

A különböző tájalkotó tényezőkre egyenként előállított fuzzy térképek együttes elemzéséhez a fuzzy halmazműveleteket kell használtunk. Az IDRISI Taiga szoftverben ezeket a halmazmüveleteket az OVERLAY eszközzel a megfelelő halmazmüvelet kiválasztásával és alkalmazásával tudtam elvégezni (Clark Labs 2011).

A vizsgálat során, annak érdekében, hogy minden tényező egyenlő súllyal legyen figyelembe véve, integrálva, a halmazmüveletek közül matematikai értelmezés szerint az egyes fuzzy térképeket átlagoltam.

Az így értelmezett fuzzy „lágy” határ, egy övezetet jelöl ki, amelyen belül a tájhatár egy rövid időszakot tekintve mozog, viszont hosszú távon ezt az övezetet nem lépi át. Az 5.2. $A$ fuzzy logikával történö megközelités eredményei fejezetben egy-egy kistáj, középtáj esetében részletesebben bemutatom ezen ökotonok elhelyezkedését és nagyságait.

\subsection{A tájak- és határaik érzékenységének vizsgálata (a mesterséges gátak okozta tájfelszabdaltság függvényében)}

A táj mintázatát az ökológiai- foltok és folyosók, alakítják ki a mátrixban (FormanGodron 1986, Formann 1995). Az ökológiai gátak lineáris (vonal-szerü) elemek. Az ökológiai gátak gyakran hasonló ökológiai adottságú tájfoltokat, élöhelyeket választanak el. Az ökológiai folyosók lehetnek természetesek (pl. egy folyó-korridor) vagy mesterségesek, gátak (barrier) az élőlények szempontjából (Kerényi 2007).

Kutatásom során csak a mesterséges gátak okozta felszabdaltságát vizsgálom, hogy azok miként hatnak a tájökológiai egységek stabilitására, határainak érzékenységére. 
A mesterséges gátak, mint pl. az utak, vasutak vagy a települések a táj egységét nagymértékben képesek megbontani. Az utak és a vasutak kettévágják az addig egybefüggő tájfoltokat, ezzel alapvetően módosítva azok ökológiai tulajdonságait (Forman - Alexander 1995, Trombulak - Frissell 2000, Forman et al. 2003). A mesterséges gátak a biom szempontjából akár teljesen elszigetelt foltokat is képesek létrehozni, megváltozva az ökológiai kölcsönhatásokat a természetes élöhely foltok között (Harris 1984, Sauders et al. 1991, Forman 1995).

A fragmentáció következtében a táj feldarabolt részeiben az ökológiai stabilitás romlik, a természetes anyag- és energiaáramlási folyamatok megváltozhatnak (Csorba 2005, Moser et al. 2007). A közlekedési infrastruktúra elemeinek (utak, vasutak) megépítésével párhuzamosan a légkörbe kerülő szennyezőanyagok mennyisége, terjedése is nő, a létesített elemek megváltozatják a helyi mikroklímát (Saunders et al. 1991, Reck - Kaule 1993, Trombulak -Frissell 2000, Spellerberg 2002, Jaeger 2002, Forman et al. 2003). A több mint 20 m széles autópálya a lefolyást és talajvízáramlást módosító hatása is számottevő (Barta Szatmári 2010, Barta et al. 2011, Kun et al. 2012).

A fent említett okok miatt a fejlett ipari-szolgáltató országokban a legveszélyesebb természetromboló folyamatnak ezt a tájfelszabdalódást tartják (Jongman 1995, Wascher Jongman eds. 2000). Minél több mesterséges gát jelenik meg a tájban az annál felszabdaltabb lesz, az addig egybefüggő folt a két vagy több részre tagolódik, a tájban addig fennálló stabilitás megváltozik. A folt nagyságával csökkenésével a stabilitása is csökkent, mindaddig a folt nagysága el nem éri a legkisebb életképes, vagy effektív populációméret (megadja annak az izolált populációnak a nagyságát, amely egy megadott időn túl fennmarad adott valószínűséggel- Gilpin - Soulé 1986). A táj fragmentáltságának növekedésével a táji egységek határának hossza is megnő, mindez a táj nagyobb fokú érzékenységét jelenti (Mas et al. 2010).

Ennek értelmében, ha megvizsgáljuk, hogy a mesterséges gátak okozta tájfelszabdaltság miként változik a közepes méretarányú tájökológiai egységekben ( kistáj), akkor képet kaphatunk azok határainak érzékenységéről és a stabilitásának változásáról is.

A mesterséges gátak okozta felszabdaltság mérésére a különböző tájmetriai mutatószámot dolgoztak ki (McGarigal - Marks 1995, Riitters et al. 1995, Haines-Young - Chopping 1996, Hargis et al. 1998, Jaeger 2000).

Jaeger (2002) huszonkettő tájmetrikai mérőszámot hasonlított össze annak érdekében, hogy megtalálja melyik a legalkalmasabb a tájfelszabdaltság mérésére. Leghatékonyabbnak a „Hatékony hálóméretet” (Effective Mesh Size ${ }_{\mathrm{CUT}}$, röviden Mesh ${ }_{\mathrm{CUT}}$ ) találta. E mutató mellett 
dolgozatomban további három tájmetriai mutatót számoltam ki (,Foltok száma”, „Felosztottság foka”, „Tájfeldarabolódási index”), melyek más-más mértékegységben fejezik ki a felszabdaltság mértékét. A mutatókat minden esetben osztályszinten (class) számoltam, vagyis a foltok (patch) a mesterséges gátak által felszabdalt táji egységek, az osztályok pedig a közepes méretarányú tájökológiai egységek ( kistáj) voltak.

\section{A felszabdaltságot mérö tájmetriai mutatók definíciói:}

- Folt szám (NP): Esetemben a mesterséges gátak hány darab tájrészre osztják fel a tájat, mértékegység: darabszám.(McGarigal - Marks 1995)

- Felosztottság foka (Division, D): Megmutatja, hogy mekkora annak a valószínüsége, hogy a vizsgált területen belül ugyanabban az időben két véletlenszerüen jelen lévő élőlény mekkora eséllyel NEM találja meg egymást, mértékegység: százalékként értelmezhető (Jaeger 2000).

$$
D=1-\sum_{i=1}^{n}\left(\frac{A_{i}}{A_{t}}\right)^{2}
$$

ahol: $n$ : foltszám, $A_{i}$ : az i-edik folt mérete, $A_{t}$ : teljes terület

- Tájfeldarabolódási index (Landscape Splitting Index, S): azon egyforma méretü terület számát jelenti, amelyekre a tájat fel kellene darabolni ahhoz, hogy az előzőekben definiált valószínűség ne változzon. Vagyis a nagyobb mértékben felszabdalt tájat, több egyenlő méretü egységre lehet felszabdalni, mértékegység: darabszám (Jaeger 2000).

$$
S=\frac{A_{t}^{2}}{\sum_{n=1}^{n} A_{i}^{2}}
$$

ahol: n: foltszám, $A_{i}$ : az i-edik folt mérete, $A_{t}$ : teljes terület

- Hatékony hálóméret (Effective Mesh Size $\underline{C U T}_{2} \underline{\text { Mesh }}_{\mathrm{CUT}}$ ): Az előzőekben definiált egyenlő nagyságú terület mérete, mértékegység: ha vagy $\mathrm{km}^{2}$ (Jaeger 2000).

$$
\operatorname{Mesh}_{C U T}=\frac{A_{t}}{S}=\frac{1}{A_{t}} \sum_{i=1}^{n} A_{i}^{2}
$$

ahol: $n$ : foltszám, $A_{i}$ : az i-edik folt mérete, $A_{t}$ : teljes terület 
Ezen tájmetriai mutatókat a tradicionálisan definiált kistájakon (Marosi-Somogyi szerk. 1990) belül a vasút - és úthálózat valamint a települések - mint mesterséges gátak figyelembevételével kiszámoltam az 1990, 2011 és a 2027-re tervezett állapotra, az OTAB (1990)-, a Térkép Kft (2011)- térinformatikai állományai és a Közlekedésfejlesztési Koordinációs Központ térképei alapján. Vizsgáltam továbbá a felszabdaltság időbeli változásait, hogy képet kapjak a táj- stabilitás, - érzékenység változásáról, illetve a gyorsforgalmi - és foúthálózat nagytávú terve (1222/2011. (VI.29.) Kormányhatározat) alapján 2027-re várható, előrejelezhető tájállapotról.

Abban az esetben, ha a kistájon belül a „,Hatékony hálóméret $t_{C U T}$ "értékéke változott 1990 és 2011 között és tovább változás nem várható az újonnan létesített mestersége gátakkal 2027ig, akkor ezekre a tájakra feltételezhető, hogy a vizsgált időszakban a természeti anyag- és energiaáramlási viszonyok megváltoztak a mesterséges gátak építésével (3.9. ábra). Ezzel szemben a jövőt tekintve - a vizsgált paraméterek esetén - nem várható újabb változás, így egy új ,stabilabb”, új egyensúlyi állapotba kerülhetnek (van Andel - Aronson 2006).

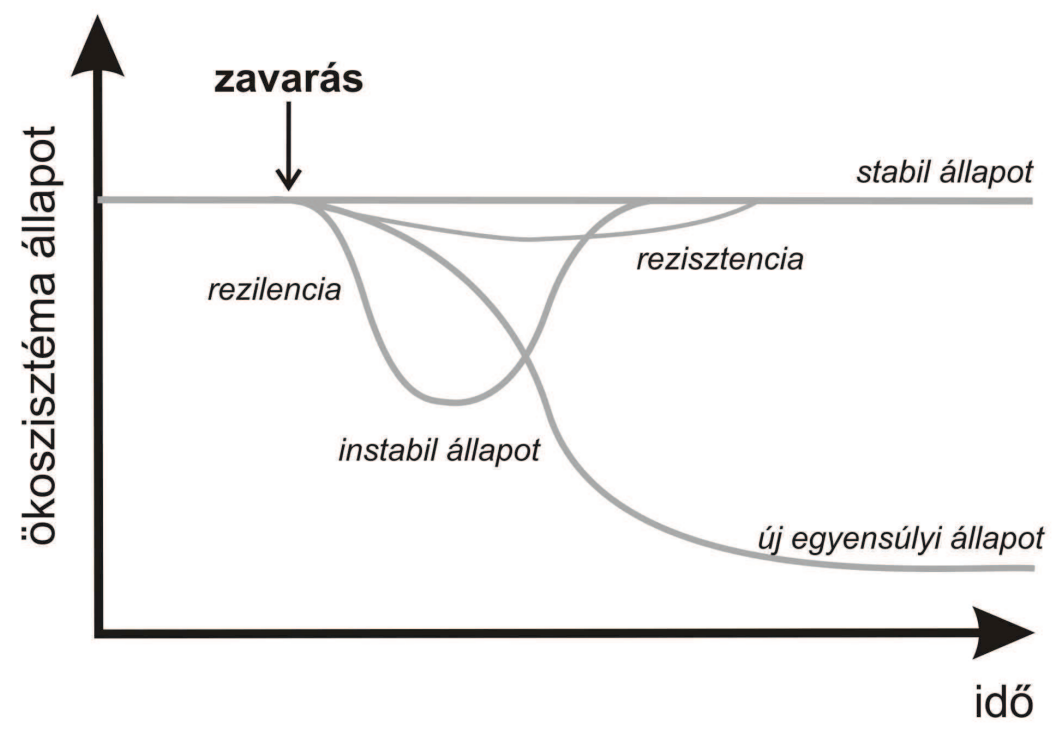

3.9. ábra: Az ökoszisztémák lehetséges válaszai zavarásokra (mint pl. a mesterséges gátak építése) van Andel - Aronson (2006) alapján

A határok érzékenységével kapcsolatosan Moser et al. (2007) felvetették annak problémáját, hogy a „Hatékony hálóméret ${ }_{C U T}$ " értéke egy vizsgált egységen belüli felszabdaltságot mutatja (közöttük szoros a korreláció). A 3.10. ábrán látható módon „Hatékony hálóméret ${ }_{C U T}$ - kiszámítási módszere hasonló elven müködik, mint egy „süteményforma”, a kiszaggatott darabon belüli hatékony hálóméretet számolja ki.

Így, ha pl. más közigazgatási hierarchiaszintre vonatkoztatva vagy más típusú tájfelosztási egységekre (szegmentált táji egységek, mely kistáj szint) szeretnénk kiszámoltatni e mutató 
alapján a felszabdaltság mértékét akkor az hatással lesz a „Hatékony hálóméret eredményére. Másrészt problémát jelent a számítási módszer abban az esetben is, ha azt vesszük alapul, hogy a természetes tájalkotó tényezők határai folyamatosan változnak, pl. elvándorol, a növényzet határa (Méri - Körmöczi 2010), a táj határa térben is időben mozgásban van, nem állandó (Mezősi-Bata 2011/a).

E probléma megoldására a számolást továbbfejlesztette Moser et al. (2007). Létrehozták a „Hatékony hálóméret ${ }_{C B C}$ - határon átnyúló kapcsolódás” (Effective Mesh Size $\mathrm{CBC}_{\mathrm{CBC}}$ - cross boundary connection, röviden $\mathrm{Mesh}_{\mathrm{CBC}}$ ) fogalmát és kiszámítását. E mutató figyelembe veszi a határon túli, de még az adott felszabdalt folthoz tartozó területeket is (3.10. ábra).

$$
\operatorname{Mesh}_{C B C}(j)=\frac{1}{A_{t j}} \sum_{i=1}^{n} A_{i j} A_{i j}^{c m p l}
$$

ahol: $n$ : a vizsgált $\mathrm{j}$ egységen belüli foltok száma, $A_{\mathrm{tj}}$ : a j-edik folt mérete, $A_{\mathrm{ij}}$ : az i-edik folt mérete, Aij ${ }^{\mathrm{cmpl}}$ :j-edik folt teljes „hasznos” területe, mely átnyúlik az i-edik folt határán

\section{CUT módszer CBC módszer}

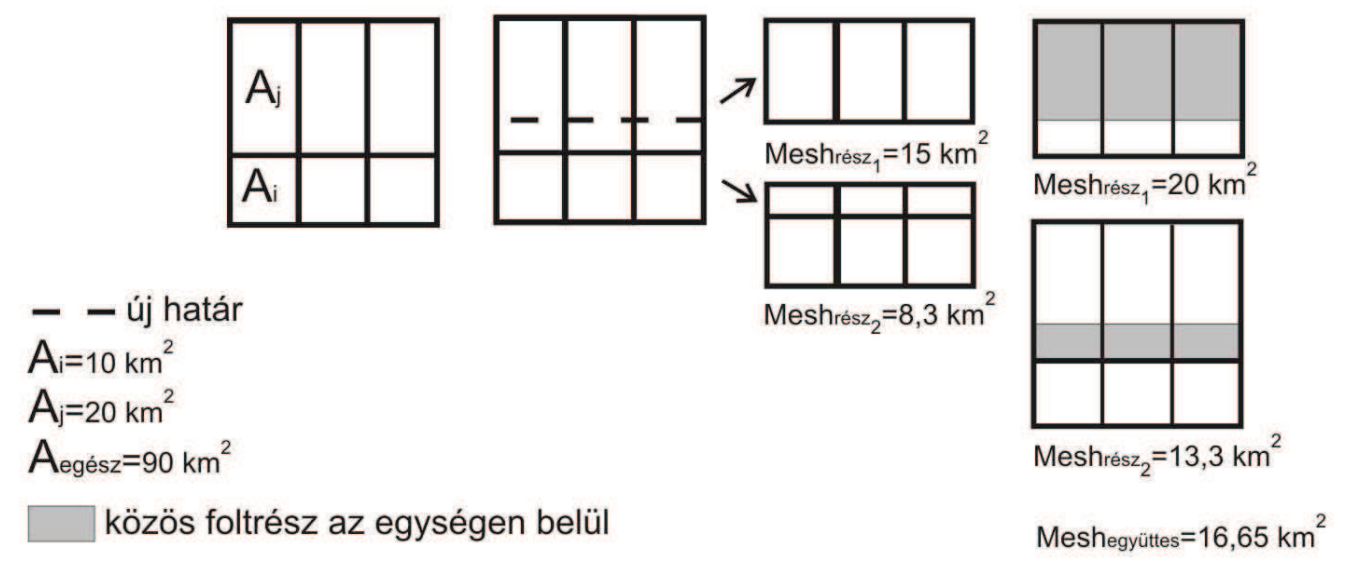

3.10. ábra: A hatékony hálóméret kétféle (CUT, CBC) számítási módszere közti különbség Moser et al. (2007) alapján

A határok érzékenyességének vizsgálatakor összehasonlítottam, a „Hatékony hálóméret” CUT és a CBC módszerével kapott eredményeiket. Megállapítható, hogy ha a CBC-vel számolt felszabdaltság nagyobb hatékony hálóméretet eredményez, akkor hogy a mesterséges gát által felszabdalt tájegység nem a vizsgált egység (jelen esetben a tradicionálisan definiált kistájak) határhoz igazodik. A mesterséges gátak megjelenésével a felszabdalódott egységek érzékenyebbé válnak, viszont az érzékenység határa, a stabilitás megváltozásának helye nem esik egybe a kistájak határaival. 
Az elvégzett vizsgálatokkal egyrészt megkaptam, hogy mely kistájak szabdalódtak fel a mesterséges gátak által a vizsgált időpontokban (1990, 2011), illetve melyeknél várható a jövőben (2027) további felszabdalás. Az időbeli változások vizsgálatakor információt kaptam a tájak stabilitásának változásáról, az esetleges változás hatásairól.

E mellett a „Hatékony hálóméret ${ }_{C B C}$ ” mutató vizsgálatba történő bevonásával kiderült, hogy kistájak határának érzékenysége milyen kapcsoltban áll a felszabdaltságukkal. 


\section{Vizsgált terület, adatok}

A 3. Alkalmazott kutatási módszerek fejezetben bemutatott vizsgálataimat minden esetben Magyarország teljes területére végeztem el, így elemzéseimben olyan adatokat, térképeket használtam, melyek hazánk teljes területére rendelkezésemre álltak (eredményeim pontosságát így az ország teljes területére vonatkozó adatok, vizsgáltok korlátozták). Egy táj sajátos arculatát a tájalkotó tényezők együttese adja meg.

\section{Természeti tájalkotó tényezők:}

- alapkőzet (talajképző kőzet),

- domborzat,

- talajtakaró,

- növényzet,

- $\quad$ vízrendszer,

- éghajlat,

- állatvilág.

Ezen természeti tényezők közül vizsgálataimban öt tényezővel, az alapkőzettel, domborzattal, talajtakaróval, növényzettel és vízrendszerrel foglalkoztam, de mivel a természeti tényezők által kialakított táj képét bármikor felülírhatja az emberi tevékenység, így az elemzéseimbe bevontam a természeti tényezőkön kívül az emberi tevékenységet is külön tényezőként (Megjegyzés: a bemutatott összes módszer más méretarányú adatokon, illetve több/kevesebb tényezö bevonásával is elvégezhetö). Ehhez a 2000-es CORINE 1:100 000-es méretarányú felszínborítási adatbázis térképből hemeróbia térképet képeztem Csorba - Szabó (2009) hemeróbia-szint beosztásának felhasználásával és kibővítésével (4.1. táblázat)

4.1. táblázat: A Hemeróbiai szintek a CORINE 2000-es adatbázis III. szintü kategóriái alapján ${ }^{2}$

\begin{tabular}{|c|c|}
\hline Hemeróbia szintek & CORINE- III. szintü kategória kódok \\
\hline 1. ahemerób & Magyarországon nincs \\
\hline 2. oligohemerób & $\begin{array}{l}\text { 3.1.1: lomblevelü erdők } \\
\text { 3.2.1: természetes gyepek, természetközeli rétek } \\
\text { 3.2.2: törpecserjés, cserjés területek } \\
\text { 3.2.4: átmeneti erdős-cserjés területek } \\
\text { 3.3.2: csupasz sziklák } \\
\text { 3.3.3: ritkás növényzet } \\
\text { 4.1.1: szárazföldi mocsarak } \\
\text { 4.1.2: tőzeglápok } \\
\text { 5.1.1: folyóvizek, vízi utak } \\
\text { 5.1.2: állóvizek }\end{array}$ \\
\hline
\end{tabular}

\footnotetext{
${ }^{2}$ A táblázat folytatódik a következö oldalon
} 


\begin{tabular}{|c|c|}
\hline Hemeróbia szintek & CORINE- III. szintü kategória kódok \\
\hline 3. mezohemerób & $\begin{array}{l}\text { 2.3.1: rét/legelö } \\
\text { 3.1.2: tülevelü erdők } \\
\text { 3.1.3: vegyes erdők }\end{array}$ \\
\hline 4. alfa-euhemeróbia & $\begin{array}{l}\text { 2.1.1: nem öntözött szántóföldek } \\
\text { 2.1.3. rizsföldek } \\
\text { 2.4.1: egynyári és állandó kultúrák vegyesen } \\
\text { 2.4.2: komplex müvelés szerkezet } \\
\text { 2.4.3: mezögazdasági területek, jelentős természetes növényzettel }\end{array}$ \\
\hline 5. béta-euhemeróbia & $\begin{array}{l}\text { 2.2.1: szölök } \\
\text { 2.2.2: gyümölcsösök }\end{array}$ \\
\hline 6. polihemerób & $\begin{array}{l}\text { 1.3.2: lerakóhelyek (meddőhányók) } \\
\text { 1.4.1: városi zöldterületek }\end{array}$ \\
\hline 7. metahemerób & $\begin{array}{l}\text { 1.1.1: összefüggő településszerkezet } \\
\text { 1.1.2: nem összefüggő településszerkezet } \\
\text { 1.2.1. ipari vagy kereskedelmi területek } \\
\text { 1.2.2: út- és vasúthálózat és csatlakozó területek } \\
\text { 1.2.3. kikötők } \\
\text { 1.2.4: repülöterek } \\
\text { 1.3.1: nyersanyag kitermelöhelyek } \\
\text { 1.3.3: építési munkahelyek } \\
\text { 1.4.2: sport- és szabadidő-létesítmények }\end{array}$ \\
\hline
\end{tabular}

Célom volt, hogy adataim a különböző matematikai-statisztikai módszerek alkalmazásakor egységesen kezelhetőek legyenek, ezért közel azonos számú kategóriába osztályoztam a felhasznált alaptérképeim kategóriát (4.2. táblázat).

4.2. táblázat: A felhasznált adatok adatforrásai és az adatok legfontosabb jellemzői

\begin{tabular}{|c|c|c|c|}
\hline Tájalkotó tényező & Forrás, méretarány & $\begin{array}{l}\text { Kategóriák } \\
\text { száma }\end{array}$ & Adattípus \\
\hline talajtakaró & AGROTOPO 1:100 000 & 31 & nominális \\
\hline talajképző kőzet & $\begin{array}{l}\text { AGROTOPO } \\
1: 100000\end{array}$ & 9 & nominális \\
\hline növényzet & $\begin{array}{c}\text { Magyarország természetes } \\
\text { növénytakarója (Zólyomi 1989) } \\
\text { 1: } 100000\end{array}$ & 22 & nominális \\
\hline $\begin{array}{l}\text { vízrendszer } \\
\text { (talaj vízgazdálkodási } \\
\text { tulajdonságai) }\end{array}$ & AGROTOPO 1:100 000 & 9 & nominális \\
\hline $\begin{array}{c}\text { emberi tevékenység } \\
\text { (Hemeróbia) }\end{array}$ & $\begin{array}{c}\text { CLC } 100 \text { (European Environment } \\
\text { Agency 2000) } \\
1: 100000\end{array}$ & 28 & nominális \\
\hline domborzat & $\begin{array}{l}\text { SRTM DEM (Shuttle Radar } \\
\text { Topography Mission 2000), } \\
\quad 90 \mathrm{~m} \times 90 \mathrm{~m}\end{array}$ & - & $\begin{array}{l}\text { numerikus } \\
\text { intervallumok }\end{array}$ \\
\hline
\end{tabular}

A kilenc kategóriába sorolást (4.3. táblázat) a talajképző kőzet és a vízrendszer kilenc kategóriája adta (ezen kategóriákat összevonni adatveszteség nélkül nem lehetett). 
A növényzet huszonkét kategóriáját egyértelmüen, információveszteség nélkül csak tíz kategóriába lehetett összevonni. Az emberi tevékenység, hemeróbia térképe hat kategóriát tartalmaz, mivel a leggyakrabban (Magyarország esetében is) használt beosztás szerint az antropogén hatás erősségét hét kategóriába sorolják (Bastian - Schreiber 1994, Blume Sukopp 1976, Kowarik 1988, Sukopp 1969). Magyarországon nem található olyan terület (mint pl. egy amazonasi őserdő), amely teljes mértékben természetesnek tekinthető, 100 \%ban mentes az emberi beavatkozásoktól (Csorba - Szabó 2009, Szilassi 2012).

A domborzat jellemzésére a lejtőszög térképet használtam fel, Az SRTM Digitális domborzati modelljéből (Shuttle Radar Topography Mission 2000) elöállított lejtőszög-térkép hisztogramja alapján osztályoztam kilenc kategóriába a „,Természetes Töréspontok” (Natural Breaks) segítségével (Jenks 1967). (Megjegyzés: A természetes töréspontok alkalmazásával elöállitott osztályok -azonos számú töréspont esetén- visszatükrözik Magyarországon azt a használatos lejtöszög beosztást $\left(0^{\circ}-2^{\circ}, 2^{\circ}-5^{\circ}, 5^{\circ}-12^{\circ}, 12^{\circ}-17^{\circ}, 17^{\circ}-25^{\circ}, 25^{\circ}\right.$ felett), melyet a mezögazdaságban a gépi megmüvelhetőség alapján alakitottak ki.)

\section{3. táblázat: A felhasznált adatok kategóriái ${ }^{3}$}

\begin{tabular}{|c|l|}
\hline Tájalkotó tényezők & \multicolumn{1}{c|}{ Kategóriák } \\
\hline & 1. köves és földes kopárok \\
& 2. homok \\
& 3. redzina talaj \\
& 4. erubáz, nyirok talajok \\
& 5. savanyú, nem podzolos BET, agyagbemosódásos BET, \\
pszeudoglejes BET \\
Talajtakaró & 6. barnaföld, BET, csernozjom-BET \\
2. sz. melléklet & 7. mészlepedékes csernozjomok, alföldi mészlepedékes \\
& csernozjom, mélyben sós alföldi mészlepedékes csernozjomok, réti \\
& csernozjomok, mélyben sós réti csernozjomok, mélyben \\
& szolonyeces réti csernozjomok \\
& 8. szoloncsák, szoloncsák-szolonyec, réti szolonyec, sztyeppesedö \\
& réti szolonyec, szolonyeces réti talajok \\
& 9. réti, réti öntés, lápos réti, síkláp, lecsapolt és telkesített síkláp, \\
& mocsári erdők talaja, fiatal, nyers öntéstalajok. \\
\hline & 1. Glaciális és alluviális üledékek \\
& 2. Löszös üledékek \\
& 3. Harmadkori és idősebb üledékek \\
Talajképző kőzet & 4. Nyirok \\
3. sz. melléklet & 5. Mészkő, dolomit \\
& 6. Homokkö \\
& 7. Agyagpala, fillit \\
& 8. Gránit, profirit \\
& 9. Andezit, bazalt, riolit \\
\hline
\end{tabular}

\footnotetext{
${ }^{3}$ A táblázat folytatódik a következö oldalon
} 


\begin{tabular}{|c|c|}
\hline Tájalkotó tényezők & Kategóriák \\
\hline $\begin{array}{l}\text { Növényzet } \\
\text { 4. sz. melléklet }\end{array}$ & $\begin{array}{l}\text { 1. homoki tölgyesek, homoki puszták } \\
\text { 2. tatárjuharos lösztölgyesek, löszpuszták, mezei juharos tölgyesek } \\
\text { 3. sziki tatárjuharos tölgyes, szolonyec sziki növényzet, szoloncsák } \\
\text { sziki növényzet } \\
\text { 4. ártéri ligeterdö } \\
\text { 5. gyertyános tölgyes, rétláp láperdőkkel } \\
\text { 6. karszterdő } \\
\text { 7. kontinentális jellegủ molyhos tölgyes, hegyi gyertyános tölgyes } \\
\text { 8. cseres tölgyes } \\
\text { 9. bükkösök } \\
\text { 10. eredeifenyővel elegyes tölgyes, erdei fenyves, lomberdők }\end{array}$ \\
\hline $\begin{array}{c}\text { Vízrendszer } \\
\text { (talaj vízgazdálkodási } \\
\text { tulajdonságai) } \\
\text { 5. sž. melléklet }\end{array}$ & 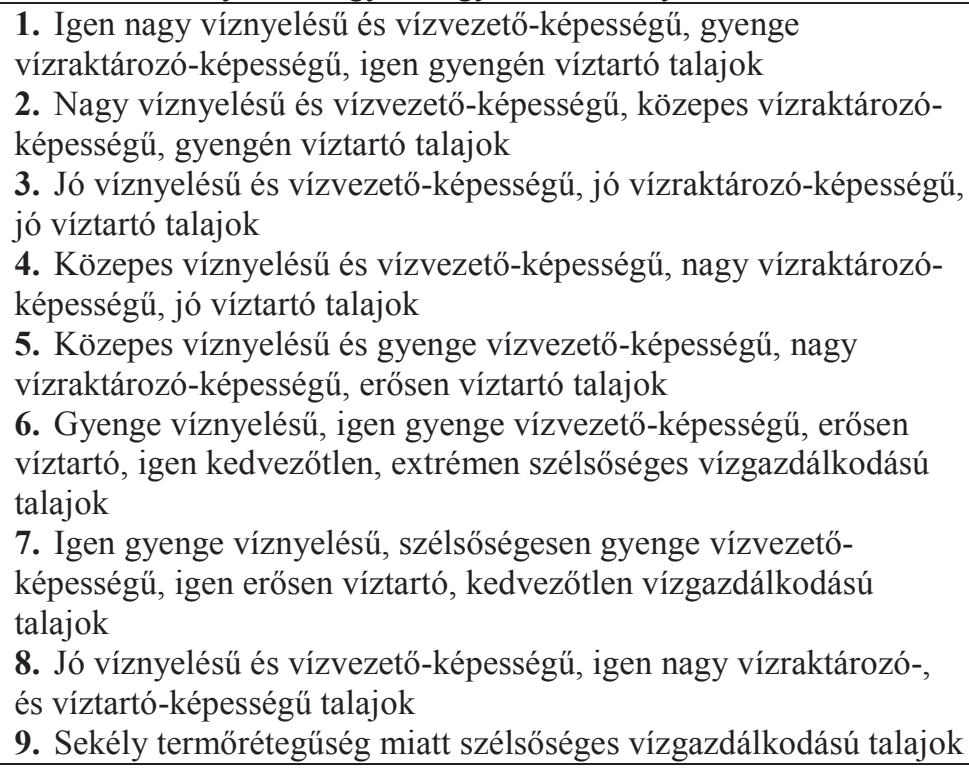 \\
\hline $\begin{array}{l}\text { emberi tevékenység } \\
\text { (Hemeróbia) } \\
\text { 6. sz. melléklet }\end{array}$ & $\begin{array}{l}\text { 1. ahemerob (Magyarországon nem jelenik meg) } \\
\text { 2. oligohemerob } \\
\text { 3. mezo hemerob } \\
\text { 4. alfa-euhemerob } \\
\text { 5. beta-euhemerob } \\
\text { 6. polihemerob } \\
\text { 7. metahemerob }\end{array}$ \\
\hline $\begin{array}{l}\text { Domborzat, lejtőszög } \\
\text { 7. sz. melléklet }\end{array}$ & $\begin{array}{l}\text { 1. } 0^{\circ}-1,14^{\circ} \\
\text { 2. } 1,15^{\circ}-2,78^{\circ} \\
\text { 3. } 3 \cdot 2,79^{\circ}-4,88^{\circ} \\
\text { 4. } 4.4,89^{\circ}-7,32^{\circ} \\
\text { 5. } 5.7,33^{\circ}-10,17^{\circ} \\
\text { 6. } 6.10,18^{\circ}-13,64^{\circ} \\
\text { 7. } 7.13,65^{\circ}-17,97^{\circ} \\
\text { 8. } 8.17,98^{\circ}-23,85^{\circ} \\
\text { 9. } 9.23,86^{\circ}-42,90^{\circ}\end{array}$ \\
\hline
\end{tabular}

Egyes vizsgálatokban felhasznált adatok a kilenc kategóriába sorolást követően (lsd. 2. - 7. sz. mellékletek) sem kezelhetők egységesen, hiszen például a talajképző kőzet, talajtakaró, növényzet, vízrendszer és az emberi tevékenység kategóriái is nominális, szövegesen leírt adatok, illetve a lejtőszög kategóriái intervallumokban megadott számadatok. Ezek matematikai-statisztikai módszerek alkalmazásánál nem kezelhetőek, szám-adattá történő átalakításuk elengedhetetlen. Az átalakítás egyik módja lehet a homogenitási érték meghatározása (Mezősi-Bata 2011/b). 
A homogenitási érték meghatározásakor a rendelkezésemre álló adatállományok alapján vizsgálom, hogy az egyes tájalkotó tényezők térbeli változékonysága milyen a közepes méretarányú tájökölógiai egységekben, jelen esetben a kistájhatárokon belül (4.1. ábra). Ezzel a megközelítéssel átalakíthatóak az egyes tájalkotó tényezők skaláris -, nominális- vagy intervallumokban megadott kategóriái is.

Közelebbről megvizsgálva egy példa a homogenitási érték meghatározására egy kistájra: Az Agrotopográfiai Adatbázis (AGROTOPO) szerint a Hanság kistájon belül a kétféle talajképző kőzetet különíthetünk el: a glaciális és alluviális üledékeket és löszös üledékeket. Utóbbi kategória a kistájon belül kettő területen is megtalálható, É-on a kistáj 24,76 \%-ában és K-en 0,90 \%-ban, míg az első kategória összefüggő területként a kistáj 74,34%-án.

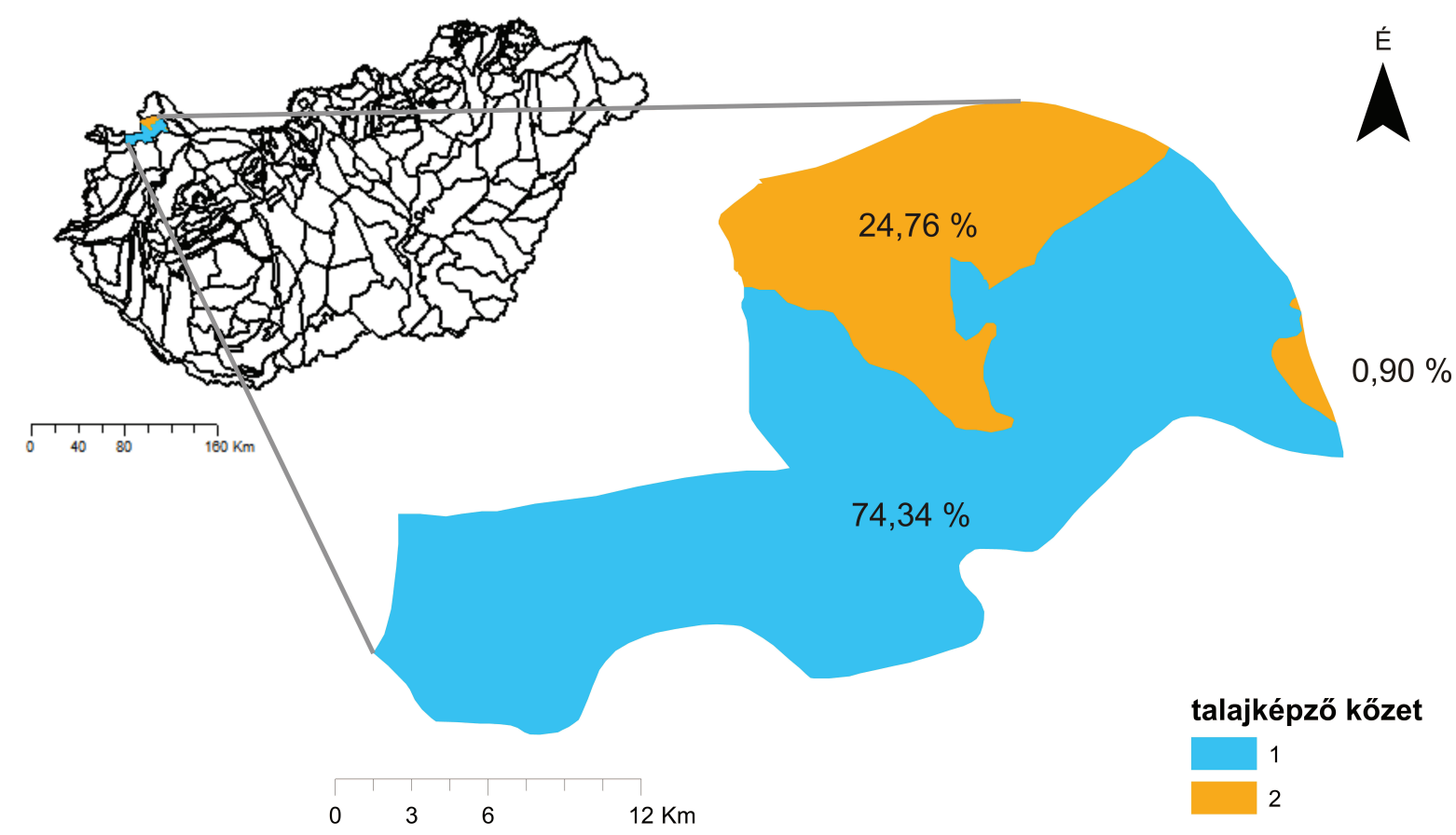

4.1.ábra: A Hanság kistáj homogenitási értékei a talajképző kőzet esetében: 1-glaciális és alluviális üledékek, 2-löszös üledékek

Ezen módszer alkalmazásával minden kistájra, a vizsgált összes (hat) tájalkotó tényezőre kiszámoltam a homogenitási értékeket (1sd. 8. - 13. sz. mellékletek). Egyes vizsgálatokban, mint pl. a tájak kiterjedésének elemzése fuzzy logikával - az így előállított homogenitási adatokat, térképek használtam fel alapadatként.

A tájalkotó tényezők szövegesen vagy intervallumokban megadott kategóriáinak adatai ezzel a megközelítéssel szám formátumúvá alakított adataival már matematikai - statisztikai elemzések készíthetők. 


\section{A tájfelszabdaltság vizsgálatához használt adatok}

A mesterséges gátak okozta tájfelszabdaltságot idősorosan is elemeztem. Vizsgáltam a felszabdaltság mértékének változását 1990 és 2010 között, illetve a 2027-re várható jövőbeli változást feltételesen számítottam ki. A következő adatokat használtam fel a mesterséges gátak típusaiból:

- úthálózat (autópálya, főút, mellékút)

- vasúthálózat

- települések belterületi határai

Az 1990-es bázisévre az OTAB (1990) adatbázis: út, vasút és településhálózatát használtam (OTAB 1990) (1sd. 14 - 16. sz. mellékletek).

A 2011-es állapothoz a Térkép Kft. rendelkezésemre bocsájtotta az említett három hálózat térinformatikai állományát (lsd. 15, 17 - 18. sz. mellékletek) a település szintü térinformatikai térképiből 1:100.000-es léptéknek megfelelő felbontással (Térkép Kft. 2011).

A jövőre elörejelezhető állapot bemutatására „A gyorsforgalmi - és foúthálózat nagytávú terve” (1222/2011. (VI.29.) Kormányhatározat) megyei térképeiről a geokorrigálást követően bedigitalizáltam a 2027-ig tervezett utak nyomvonalait. A digitalizált nyomvonalakat az általam készített egységes úthálózati adatbázishoz (lsd. később) illesztettem (lsd. 19 - 20. sz. mellékletek).

Az eltérő időpontban készített adatbázisok úthálózati térképei egymáshoz hasonlítva tartalmilag nem koherensek, a legtöbb útszakasz, mely már az 1990-es évben is létezett, a 2011-es térképen attól elcsúszva található, azaz nem illeszkednek megfelelően. Hasonló probléma fedezhető fel a települések hálózatainál is. Ennek oka, hogy jelenleg nincs olyan egységes adatbázis, mely a települések belterületi határait tartalmazná az 1990-es és az 2011es időszakból is, a különböző adatbázisok összehasonlításában nem egyszerü a térbeli pontatlanság kiküszöbölése, mivel a vizsgált időszakban, ha összehasonlítjuk a települések méretét és helyzetét, nem minden területnövekedés tudható be a település növekedésének.

Ezen a hibák pozitív vagy negatív irányban is befolyásolhatják a tájfelszabdaltsági eredményeket. A tartalmi pontatlanság kiküszöbölésére egyrészt egy olyan egységes úthálózati adatbázist hoztam létre (alapja a tartalmilag pontosabb 2011-es úthálózat volt), ahol az attribútum táblában külön jelölve vannak, hogy melyik útszakaszok voltak már meg 1990ben és külön, hogy melyeket hoztak létre 1990 és 2011 között. 
E módszer segítségével csak a települések tekintetében kell hibaküszöbbel számolnom. A vizsgálataim során ennek értéke a két különböző alapadatbázis településeiböl számolt méretkülönbségek átlaga volt, melynek értéke 24,63 ha.

A tájfelszabdaltságot mérő vizsgálatokban, a vasutak és az utak, nemcsak mint vonalas objektumok értelmezettek, hanem átlagos 2D-s kiterjedésük (Fi et al. 2012, Megyeri 1997) is figyelembe lett véve a következők szerint (hasonlóan a települések 2D - s alakjához):

- $\quad$ autópálya átlagos szélessége $=26,6 \mathrm{~m}$ (4.2. ábra)

- $\quad$ fő́t átlagos szélessége $=7 \mathrm{~m}$

- $\quad$ mellékút átlagos szélessége $=3 \mathrm{~m}$

- $\quad$ vasút átlagos szélessége $=6,05 \mathrm{~m}$

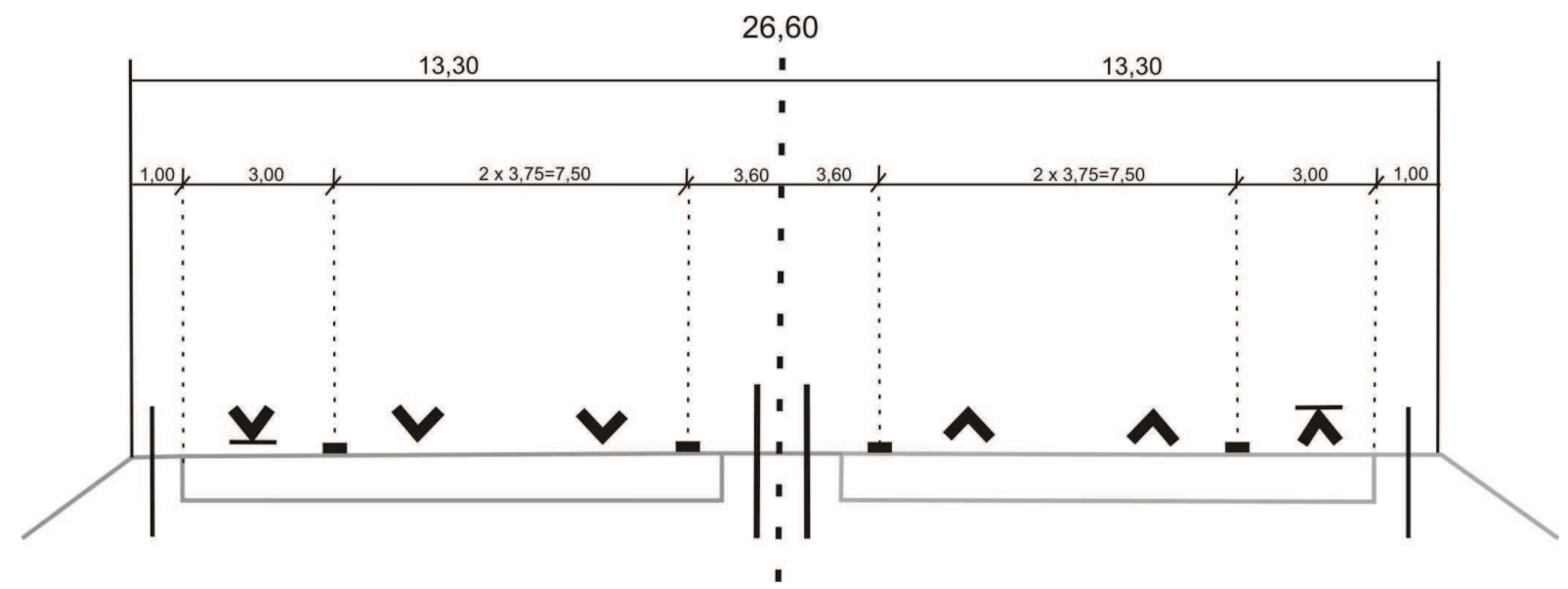

4.2. ábra: Egy autópálya keresztmetszeti képe Fi et al. (2012) alapján.

A tájból ezek az elemek a hosszúságuk függvényében a megadott szélességgel szorzott területnagyságokat fednek le, hasonlóan a települések kiterjedésükkel „vakfolt”-okat jelentenek a természetes élővilág számára. Az M5-ös autópálya pl. Budapest és Szeged között 173 km hosszú, vagyis ezen autópálya - a lehajtók, felhajtók nélkül - a Duna Tisza közén a tájból (173 km x 26,6 m) 4,6 $\mathrm{km}^{2}$-nyi területet foglal el. Az anyag és energiaáramlási viszonyok ezeken a területek, illetve e terület puffer zónájában változnak a legerősebben. 


\section{Eredmények és következtetések}

\subsection{Többváltozós szegmentációval kapott eredmények}

A közepes méretarányú tájökológiai egységek objektív, matematikailag, statisztikailag meghatározott lehatárolására (szegmentálására) egy többváltozós szegmentációs eljárást (multiresolution segmentation) alkalmaztam.

A szegmentációt a hat tájalkotó tényező kategorizálása után készített tematikus térképinek felhasználásával végeztem el. Az előkészítés során ezeket a vektoros formátumú térképeket 100 m-es felbontású raszteres térképekké alakítottam. Ezek voltak a szegmentáció bemeneti rétegei (egy több - jelen esetben hat - sávos légifotó elemzéséhez hasonlóan, csak itt a sávok az egyes tematikus térképek).

Annak érdekében, hogy a szegmentálás során kizárólag a raszteres térképek spektrális tulajdonságait, vagyis a tájalkotó tényezők típusait vegye figyelembe az eljárás, az „alak” paramétert a legmagasabb 0,9-es értékre állítottam be. Elkerülve azt, hogy előre definiált legyen a szegmentált táji egységek tömörsége, a „tömörség” paramétert, a semlegesnek tekintett, 0,5-es értékre állítottam. Ezen beállítások alkalmazása teljesítette azt a kritériumot, hogy a lehatárolás a lehető legnagyobb mértékben objektív legyen.

A többváltozós szegmentáció folyamata érzékeny a felhasználó által megadott „skála” paraméterre. Egy heterogénebb területen kisebb lesz a szegmentált folt mérete, mint egy homogénebb területen, ezért a vizsgálat során iterációs megközelítést használtam annak érdekében, hogy megtaláljam, melyik beállítás a legalkalmasabb a közepes méretarányú tájökológiai egységeket lehatárolásához.

A „,skála” paraméter értékét ezért az 50-es értékbeállítástól kezdődően 10-es különbséggel 400-ig növeltem (5.1. táblázat).

5.1. táblázat: A szegmentált táji egységek eredményei különbözö „skála”értékbeállításoknál ${ }^{4}$

\begin{tabular}{|c|c|c|c|c|}
\hline $\begin{array}{c}\text { Skála } \\
\text { paraméter }\end{array}$ & $\begin{array}{c}\text { Szegmentált } \\
\text { foltok száma }\end{array}$ & $\begin{array}{c}\text { Legnagyobb } \\
\text { folt területe } \\
\left.\mathbf{( k m}^{\mathbf{2}}\right)\end{array}$ & $\begin{array}{c}\text { Foltok átlagos } \\
\text { területe } \mathbf{( k m}^{\mathbf{2}} \mathbf{)}\end{array}$ & $\begin{array}{c}\text { Legkisebb } \\
\text { folt területe } \\
\mathbf{( k m}^{\mathbf{2}} \mathbf{)}\end{array}$ \\
\hline 300 & 41 & 7263,83 & 2168,12 & 17,4 \\
\hline 270 & 44 & 7263,83 & 2113,48 & 17,4 \\
\hline 250 & 56 & 6994,48 & 1660,55 & 17,18 \\
\hline
\end{tabular}

\footnotetext{
${ }^{4}$ A táblázat folytatódik a következö oldalon
} 


\begin{tabular}{|c|c|c|c|c|}
\hline $\begin{array}{c}\text { Skála } \\
\text { paraméter }\end{array}$ & $\begin{array}{c}\text { Szegmentált } \\
\text { foltok száma }\end{array}$ & $\begin{array}{c}\text { Legnagyobb } \\
\text { folt területe } \\
\mathbf{( k m}^{\mathbf{2}} \mathbf{n}\end{array}$ & $\begin{array}{c}\text { Foltok átlagos } \\
\text { területe } \mathbf{( k m}^{\mathbf{2}} \mathbf{)}\end{array}$ & $\begin{array}{c}\text { Legkisebb } \\
\text { folt területe } \\
\mathbf{( k m}^{\mathbf{2}} \mathbf{)}\end{array}$ \\
\hline 210 & 78 & 4950,4 & 1192,13 & 17,18 \\
\hline 190 & 92 & 4950,4 & 1010,71 & 13,16 \\
\hline 150 & 131 & 3612,39 & 709,81 & 13,16 \\
\hline 130 & 174 & 3365,22 & 534,4 & 10,47 \\
\hline 120 & 201 & 3365,22 & 462,6 & 10,47 \\
\hline $\mathbf{1 1 5}$ & $\mathbf{2 3 0}$ & $\mathbf{2 5 9 3 , 6 2}$ & $\mathbf{4 0 4 , 2 7}$ & $\mathbf{7 , 4 8}$ \\
\hline 110 & 260 & 2593,62 & 356,26 & 7,48 \\
\hline 70 & 548 & 1188,32 & 166,03 & 7,48 \\
\hline 50 & 1067 & 1008,34 & 87,14 & 2,54 \\
\hline
\end{tabular}

A ,skála” 115-ös értékbeállításánál kaptam a tradicionális definiált kistájainkkal megegyező számú, ennek következtében összehasonlítható közepes méretarányú tájökológiai egységeket. A szegmentált táji egységeket különböző tájmetriai mutatók kiszámítása révén hasonlítottam össze a tradicionálisan definiált kistájakkal (5.2. táblázat).

5.2. táblázat: A természetességet és az érzékenységet jól mutató tájmetriai mérőszámok eredményei a tradicionálisan definiált kistájaknál és a szegmentált táji egységeknél

\begin{tabular}{|l|c|c|}
\hline Tájmetriai mérőszám & $\begin{array}{c}\text { Tradicionálisan } \\
\text { definiált kistájak }\end{array}$ & $\begin{array}{c}\text { Szegmentált táji } \\
\text { egységek }\end{array}$ \\
\hline Természetességet mutatja: & 230 & 230 \\
\hline Foltok száma (NP) & 1829,15 & 2593,62 \\
\hline Legnagyobb folt mérete (LP) $\left.\mathbf{( k m}^{\mathbf{2}}\right)$ & 11,45 & 7,48 \\
\hline Legkisebb folt mérete (SP) $\mathbf{( k m}^{\mathbf{2}}$ & 404,35 & 404,26 \\
\hline Átlagos folt méret (MPS) $\left(\mathbf{k m}^{\mathbf{2}}\right)$ & 1,184 & 1,216 \\
\hline Fraktáldimenzió átlaga (MFRACT) & & 33752,00 \\
\hline Érzékenvséget mutatja: & 13428,28 & 37,39 \\
\hline Össz határhossz (km) & 30,05 & 37,39 \\
\hline Foltonkénti határhossz átlaga (km) & 30,05 & 2,31 \\
\hline $\begin{array}{l}\text { Magterületi index (\%), } \mathbf{~ k m ~ - e s ~} \\
\text { szegéllyel számolva }\end{array}$ & 1,72 & \\
\hline Átlagos Alaki index (MSI) & \multicolumn{2}{|c|}{} \\
\hline
\end{tabular}

A szegmentált táji egységek esetében az „ $L P ”$ értéke 2593,62 km², az SP értéke 7,48 km². Az „LP” és „,SP” értékének különbsége $2586,14 \mathrm{~km}^{2}$. A tradicionálisan definiált kistájak esetében a legnagyobb és a legkisebb folt közötti különbség $1817,7 \mathrm{~km}^{2}$ (, $L P$ ” értéke $1829,15 \mathrm{~km}^{2}$, „SP” értéke 11,45 $\mathrm{km}^{2}$ ). Az objektív többváltozós szegmentáció eredményeként ugyanannyi $(230 \mathrm{db})$ táji egységet különítettem el, mint a tradicionálisan 
definiált kistájak esetében. Az „MFRACT” érték növekedett, míg a „MPS” értéke csökkent a szegmentáció eredményeként. A tájmetriai mutatók ilyen irányú változásai azt mutatják, hogy a szegmentált táji egységek természetesebb keretet jelentenek, mint a tradicionálisan definiált kistájak, mert a szegmentált táji egységek metrikailag összetettebbek, fragmentáltabbak, így a határai természetesebbek. Ezek az eredmények összecsengenek Herzog et al. (2001) és Renetzeder et al. (2010) eredményeivel.

A „Határok összhossza” a tradicionálisan definiált kistájak esetében 13428,28 km, a szegmentált táji egységeknél 33752,00 km. A „Foltonkénti határhossz” átlagokat tekintve viszont a különbség nem nagy $(88,37 \mathrm{~km})$ a kétféle tájlehatárolásban. A kiszámolt „Magterületi index” értéke a szegmentált táji egységeket vizsgálva 37,39 \%, míg a tradicionálisan definiált kistájaknál 30,05 \%. Ugyanakkora méretủ szegéllyel számolva így a szegmentáció eredményében kisebb a magterület és a szegmentált táji foltok nagyobb mértékben fragmentáltak, ezt az állítást alátámasztja az a tény is, hogy tizenkilenc táji egység teljes egésze az alkalmazott szegélyzónában helyezkedik el, így magterülete $0 \%$. Az „Alaki index" átlagértéke 2,31, sokkal magasabb, mint a tradicionálisan definiált kistájak vizsgálatában. Ezen eredmények Mas et al. (2010) értelmezései alapján azt mutatják, hogy az objektív többváltozós szegmentáció eredményéül lehatárolt közepes méretarányú táji egységek érzékenyebbek, mint a korábbi tradicionálisan definiált kistájak.

A síkvidéki $(0,0-200,0 \mathrm{~m})$, a dombvidéki $(200,1-500,0 \mathrm{~m})$ és a hegyvidéki (> 500,0 m) kategóriák oldaláról összehasonlítottam a szegmentált táji egységek és a tradicionálisan definiált kistájak számát, a három kategória százalékos megjelenését, illetve átlagos heterogenitási értékeket bemutatom be (5.3. táblázat és 5.1. ábra).

5.3. táblázat: Foltok száma, a kategóriák magyarországi megoszlása és az átlagos heterogenitási értékek a tradicionálisan definiált kistájak és a szegmentált táji egységek összehasonlitásában

\begin{tabular}{|c|c|c|c|c|}
\hline & & $\begin{array}{l}\text { Foltok } \\
\text { száma }\end{array}$ & $\begin{array}{l}\text { Magyarországi } \\
\text { megoszlás (\%) }\end{array}$ & $\begin{array}{c}\text { Átlagos } \\
\text { heterogenitás } \\
\end{array}$ \\
\hline \multirow{3}{*}{$\begin{array}{l}\text { Tradicionálisan } \\
\text { definiált kistájak }\end{array}$} & $\begin{array}{c}\text { síkvidék } \\
(0-200 \text { m) }\end{array}$ & 97 & 63,4 & 3,5 \\
\hline & $\begin{array}{c}\text { dombvidék } \\
(200,1-500 \text { m) }\end{array}$ & 88 & 28,0 & 3,3 \\
\hline & $\begin{array}{c}\text { hegyvidék } \\
\text { (>500 m) }\end{array}$ & 45 & 8,6 & 3,8 \\
\hline \multirow{3}{*}{$\begin{array}{l}\text { Szegmentált } \\
\text { táji egységek }\end{array}$} & $\begin{array}{c}\text { síkvidék } \\
(0-200 \text { m) }\end{array}$ & 145 & 61,9 & 2,3 \\
\hline & $\begin{array}{c}\text { dombvidék } \\
(200,1-500 \mathrm{~m})\end{array}$ & 66 & 32,0 & 3,3 \\
\hline & $\begin{array}{c}\text { hegyvidék } \\
\text { (>500 m) }\end{array}$ & 19 & 6,1 & 3,5 \\
\hline
\end{tabular}


A szegmentált táji egységek száma az alföldi területeken magasabb (145), mint a tradicionálisan definiált kistájak esetében (97). A többváltozós szegmentáció eredményéül hatvanhat táji egység határolódott le a dombvidéki, és tizenkilenc a hegyvidéki területekre, míg a tradicionális lehatárolásban ezen értékek rendre 88 és 45.

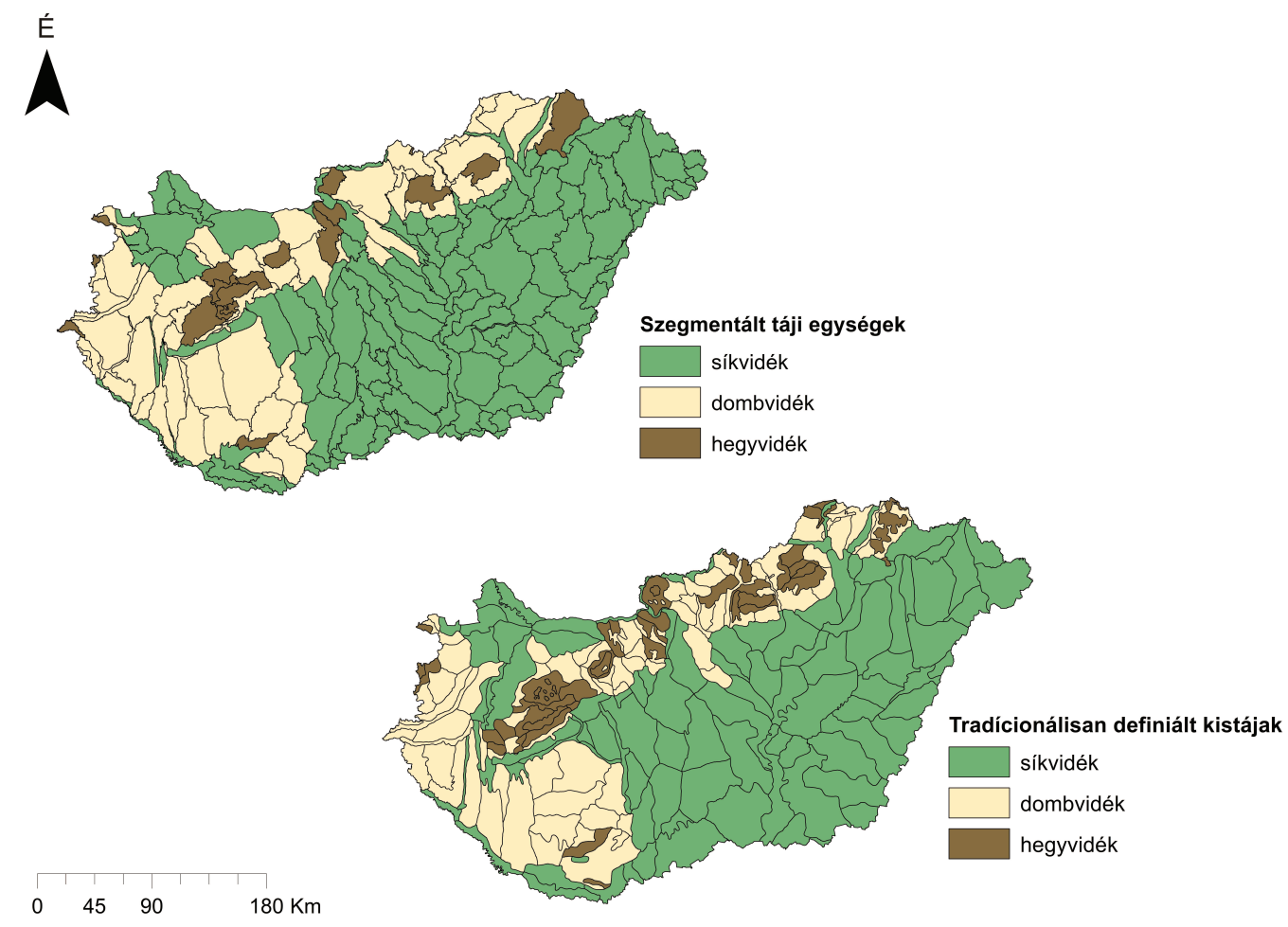

5.1. ábra: A tradicionálisan definiált kistájak és a szegmentált táji egységek a síkvidék, dombvidék, hegyvidék kategóriák tükrében

A szegmentált táji egységek átlagos heterogenitása alacsonyabb az alföldi (2,3) és hegyvidéki $(3,5)$ kategóriákban, míg a dombvidéki területen mindkét tájfelosztás átlagos heterogenitása 3,3. Ezen eredmények alátámasztják, hogy a szegmentált táji egységek az integrálás során jobban illeszkednek a felhasznált alapadatok kategóriáihoz.

\subsection{A fuzzy logikával történő megközelítés eredményei}

A határok mindenütt keskenyebb-szélesebb, esetleg több $\mathrm{km}$ széles ökotonokként értelmezhetők, éles választóvonalhoz a határ gyakran nem illeszthető a tájalkotó tényezők tulajdonságai alapján. Ezen elméletet matematikailag a fuzzy logika alkalmazásával közelítettem meg.

Az elemzésben főként természeti adatokat (természeti tájalkotó tényezők) használtam fel, kivételt képez az antropogén hatást bemutató hemeróbia szint (és ilyen korlátja lesz az 
eredménynek is). A kis-és a középtájak léptékéhez illeszkedően 1:100 000 méretarányú térképek talajtani, litológiai (talajképző kőzet), vegetációs, domborzati, vízgazdálkodási adatokat és hemeróbia-szintek adatait használtam fel. Minden kistájra vonatkozóan a korábban kiszámolt tájalkotó tényezők homogenitási értékei adták a számítás alapját. ( $l_{s} d .4$. Vizsgált terület, adatok fejezet).

A számításhoz használt hat tájalkotó tényezőt figyelembe véve azokat a területeket sikerült meghatározni, amelyek mindegyikénél jelentős az inhomogenitás. Ezt azt jelenti, hogy ezek a területek, zónák (ökotonok) olyannak tekinthetők, ahol a táj határ megvonása - e hat tényező alapján - bizonytalan. Ezzel szembe azonosíthatóak azok a területek is, amelyeknél e tényezők jóval homogénebbek és emiatt tekinthetőek tájökológiai szempontból a tájak magjainak (5.2. ábra).

Az eredmények megerősítik azt a megfigyelést, hogy a különböző típusú tájak közötti ökotonok szélessége - méretaránytól függően - nagyon tág intervallumban változik, néhány tucat m-től sok száz km-ig terjedhet (Bastian 1997, Forman 1995). A hazai területeken az alkalmazott módszerrel néhány 100 m és 3-5 km közötti értékek adódtak.

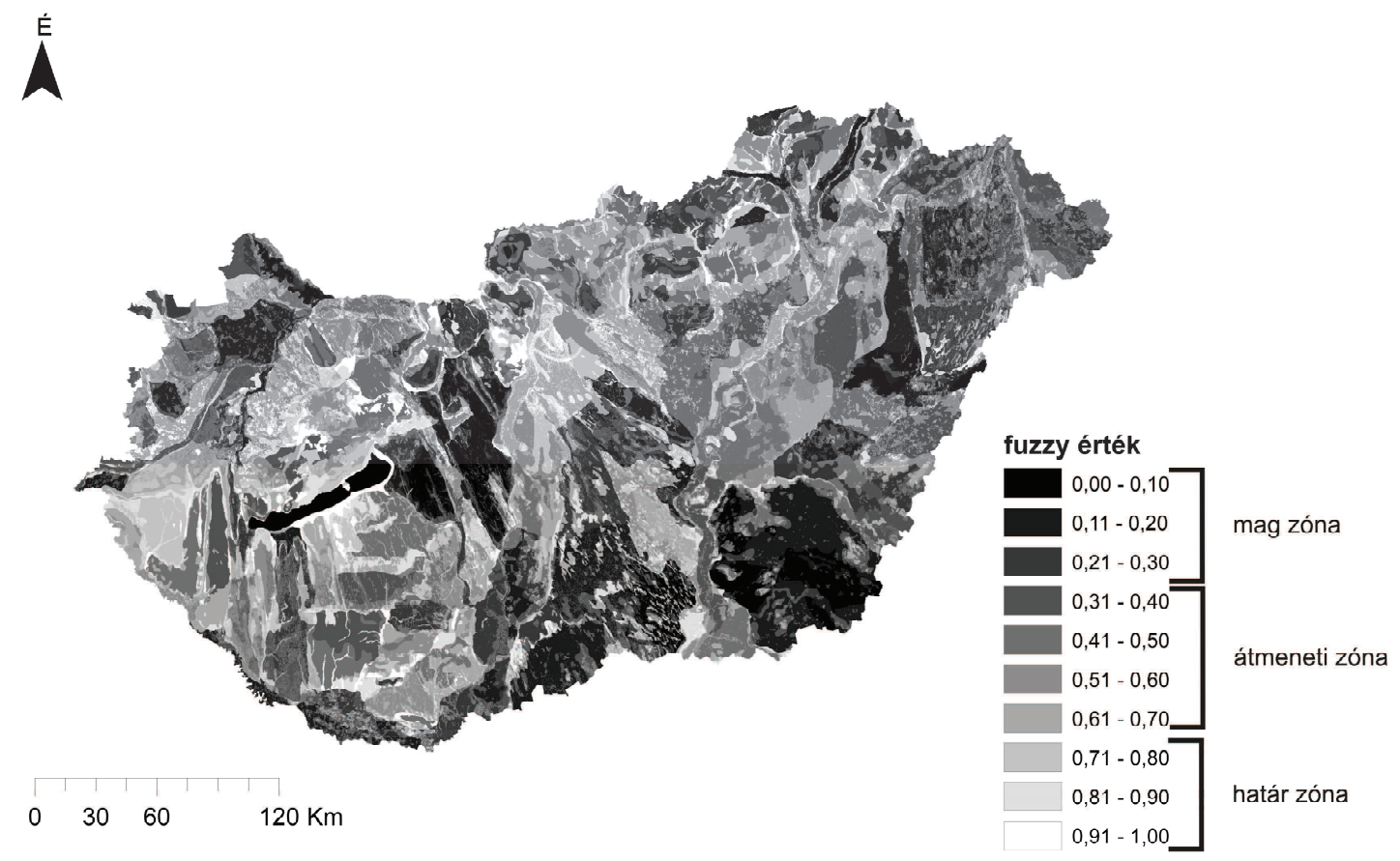

5.2. ábra: Fuzzy eredménytérkép a hat tájalkotó tényező alapján

A statisztikai vizsgálatok szerint a fuzzy átlagos értéke: 0,71. Az eredményadatokat tíz kategóriába összesítettem. A 0,00-0,30 fuzzyértékü területek (5.3. ábra: fekete oszlopok) a felszín 24,71 \%-át fedik és tekinthetőek a tájak „magjainak”. Másfelől 0,71-1,00-es fuzzy értékű területek (5.3. ábra: fehér oszlopok) a felszín közel 21,35 \%-át foglalják el, amely területeken a fenti tényezők alapján a határ bárhol húzható. Ezen túl mintegy 52,94 \%-nyi az 
ezen értékek közötti átmeneti zóna (5.3. ábra: szürke oszlopok). Itt a határt -magyarázhatóan másképp vonják meg vegetációs, vagy épp domborzati szempontú kutatások. A sok tényező együttes figyelembe vétele esetén széles inhomogén ökoton adhat a tájak elválasztására megoldást.

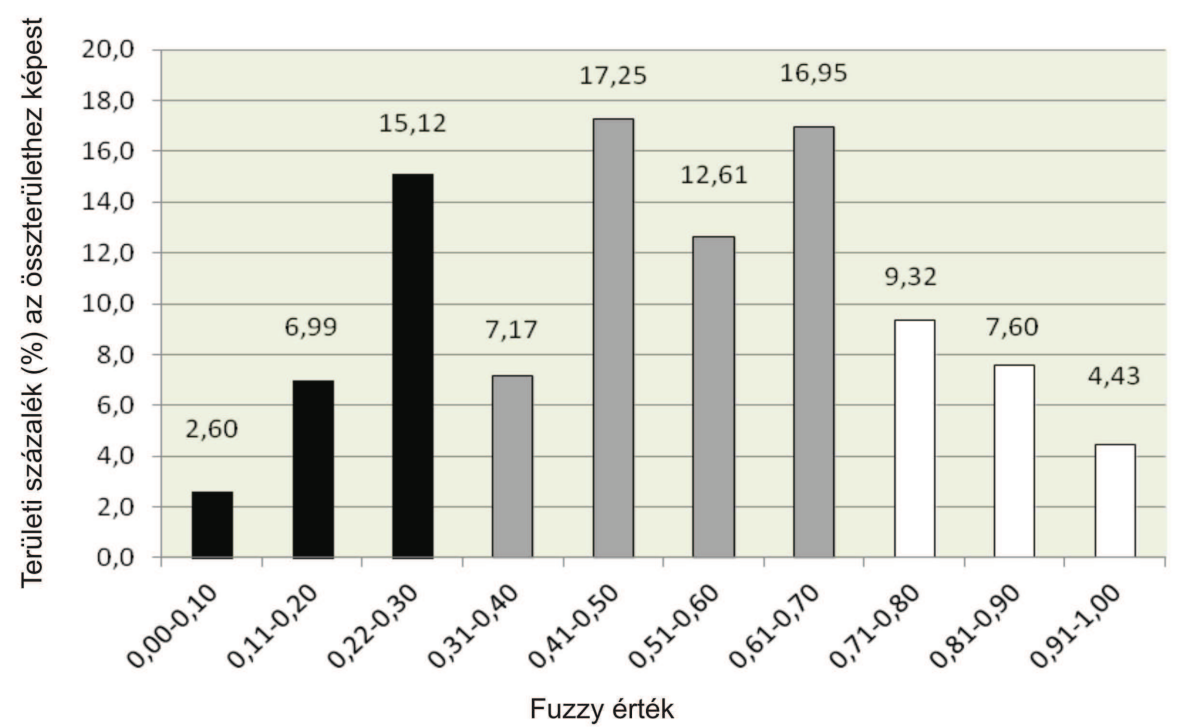

5.3. ábra: Fuzzy értékkategóriák százalékos megoszlása az összterülethez képest

Részletesebben elemezve két mintaterületi példát mutatok be. Az egyik a Kiskunságilöszöshát, amelynek különösen DNy-i részén bizonytalan a határ megvonása. A kistáj e részén egy közel 3-7 km-es zóna statisztikailag 41,5\%-ban tartozhat inkább a táji maghoz ( 59,5 \%-ban a határzónák zónához). A gondot a nagyobb területü inhomogén foltok jelentik (amelynek 0,7 fuzzy értékéhez `többnyire alacsony homogenitás tartozik.) Ezeken a területeken érhető, ha a vegetáció alapján néhányan (Deák 2010) a tájhatár módosítását javasolják. Ez a zóna a szélesebb ökotonokra jelent példát (5.4. ábra). 


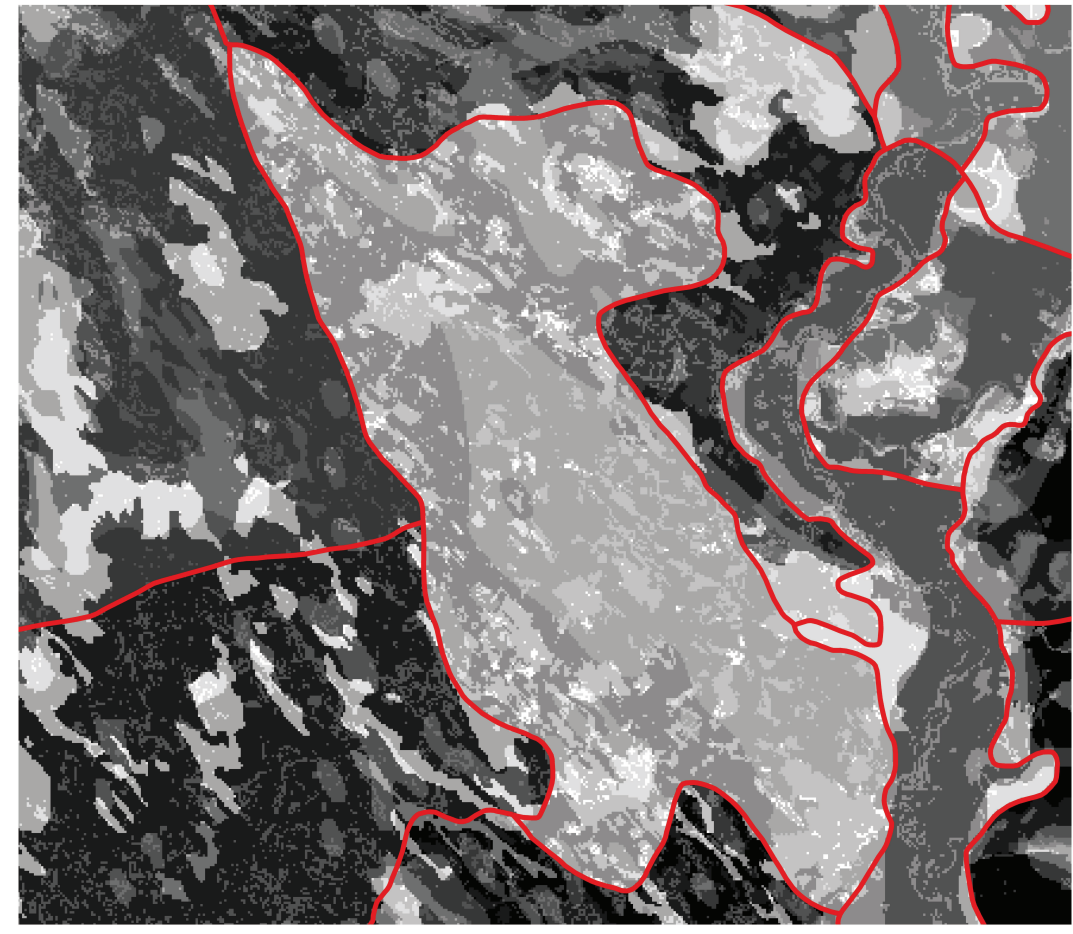

$0 \quad 4 \quad 8 \quad 16 \mathrm{Km}$
— kistáj határa

fuzzy érték

$0,00-0,10$

$0,11-0,20$

$0,21-0,30$

$0,31-0,40$

$0,41-0,50$

$0,51-0,60$

$0,61-0,70$

$0,71-0,80$

$0,81-0,90$

$0,91-1,00$

5.4. ábra: A Kiskunsági-löszös hát kistáj térképe a fuzzy logika alapján

A másik példa a Kelet-Külső-Somogy területéről származik (5.5. ábra). Itt élesen kirajzolódik a Koppány-völgy (0,63-0,80 fuzzy értékkel rendelkezik), igazolva a folyók önálló egységként történő kezelésének indokoltságát. Azaz ezek a völgyek automatikusan statisztikai szempontból - nem illeszthetők egy tájegységhez. Ettől D-re a kis homogenitású terület (fuzzy érték 0,41) olyan, ahol az adatok alapján tájhatár nem egyértelműen vonható meg. Ez a mintegy $6 \mathrm{~km}$-es sáv megint csak ökotonként kezelhető, bár az adatok azt is sejtetik, hogy a környezettől való jelentős eltérés itt a talaj nem következetes csoportosításból adódik (pl. nem feltétlenül indokolt barna erdőtalaj és barnaföld elkülönítése a kiindulási adatbázisban, vagy minden eltérö altípust kellett volna alkalmazni). 


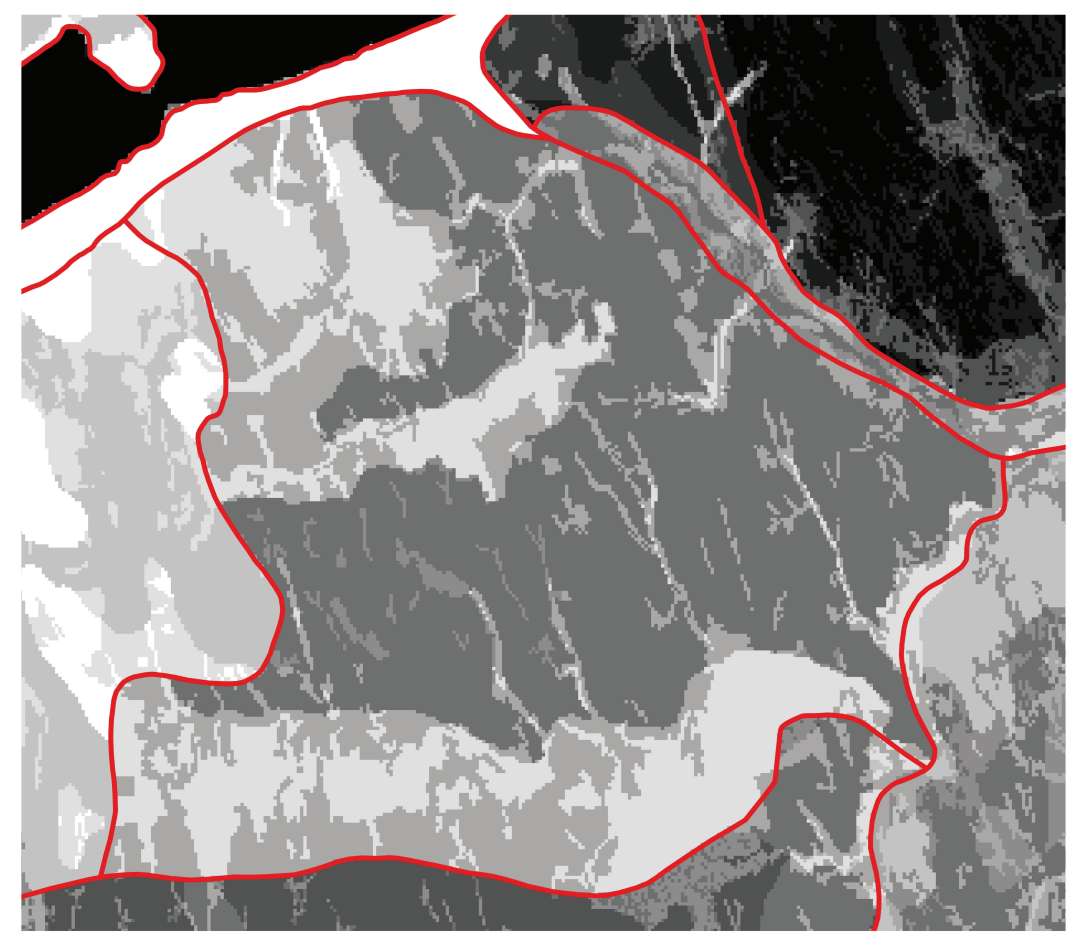

$02,55 \quad 10 \mathrm{Km}$

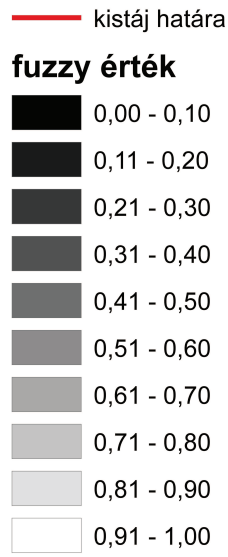

5.5. ábra: A Kelet-Külső-Somogy kistáj térképe a fuzzy logika alapján

\subsection{Validáció: összehasonlító elemzések a többváltozós szegmentáció - és a fuzzy módszerek eredményeivel}

Ebben az esetben a klasszikus pl. távérzékelt adatokon elvégzett szegmentációk validációk, mint pl. terület-alapú vagy elhelyezkedés alapján átfedés vizsgálati mérések (Clinton et al. 2010, Möllner et al. 2007, Shi et al. 2005, Johansen et al. 2010) nem végezhetőek el. A problémát a validáció során az jelentette, hogy nincs egy pontosan definiált Magyarországra vonatkozó tájfelosztás, vagyis nincs egy alap, referencia tájfelosztás, melyhez a többváltozós szegmentációval készített felosztást validálhattam volna.

Ezzel ellentétben számos módosítási javaslat, új lehatárolás látott napvilágot (pl. Ladányi 2010, Deák 2010, Molnár et al. 2008, Mezősi - Bata/b), melyek többnyire, ha nem is az egész országra vonatkozóan, de több kistáj, középtáj esetében tájhatár módosítási eredményeket közöltek (Mezősi - Bata 2011/a, Bata et al. 2013).

A fent említett validációs módszerek alkalmazhatósági problémái miatt, annak érdekében, hogy megvizsgáljam a különböző tájfelosztások és tájhatár módosítási javaslatok minőségét, hasonlóságait, komplex és regionális összehasonlító elemzéseket is végeztem. 
A komplex összehasonlításokban az összes magyarországi szegmentált táji egységet hasonlítottam össze (1) a tradicionálisan definiált kistájakhoz, (2) a LANMAP (ELCAI 2005) egységeihez és (3) a vegetációs alapú tájbeosztáshoz (Molnár et al. 2008). A vegetációs alapú tájbeosztás főként a botanikusok által végzett terepi növényzeti felméréseken alapul, de a biotikus tényezőkön kívül a felosztáskor figyelembe vettek abiotikus tényezőket is, mint pl. geológia, klíma (Molnár et al. 2008).

A regionális összehasonlító elemzésekben azokat a szegmentált táji egységeket használtam, ahová részletesebb terepi felméréseket is felhasználó módosítási javaslatok készültek, pl. Ladányi (2010) az Illancs kistájra vagy pl. Deák (2010) a Kiskunsági- löszös hát és a Dél-Tisza völgy kistájakra. Ezek a regionális összehasonlítások felhasználtam a fuzzy logikával értelmezett határzónák, mag zónák és átmeneti területek eredményeit is.

\subsubsection{Komplex összehasonlító elemzések}

Ahhoz, hogy a különböző tájfelosztások határait össze lehessen hasonlítani, a határok vonalait 1 km-es szélességü raszteres „zónákká” célszerü alakítani. Azért az 1 km-es szélesség tünt alkalmas választásnak, mert a fuzzy logikával történő értelmezésben a határzónák átlagos szélessége is ennyinek adódott. Ez az átalakítás segít a határok összevetésében, mert a felosztások határai vonalként értelmezve egymást maximum csak metszik, átfedést így nem lehet vizsgálni, míg a „zónákkal” történő megközelítésben minden vonal kap egy azonos méretü pixeles interpretációt, így az átfedések is értelmezhetőek.

Mint az 5.4. táblázatban is látható, hogy a tradicionálisan definiált kistájak határai 40,72 \%-ban fedik a Vegetációs alapú tájbeosztás határait, fordítva az átfedés mértéke 35,12 \%. A két mérés közti különbség az eltérő felosztások határainak eltérő hosszából adódik.

A LANMAP táji egységeinek határai 33,14 \%-ban egyeznek meg a vegetációs alapú tájbeosztás határaival. A szegmentált táji egységek határai is a legnagyobb átfedést a vegetációs alapú tájbeosztás határaival mutatják (63,33\%).

A komplex összehasonlító elemzések is azt tükrözik, hogy a szegmentált táji egységek megfelelően alkalmazhatóak lennének a költséges terepi felméréseket is tartalmazó felosztások, illetve a tradicionálisan definiált kistáj szintű felosztás esetleges kiváltására. 


\begin{tabular}{|c|c|c|c|c|}
\hline & $\begin{array}{c}\text { Tradicionálisan } \\
\text { definiált kistájak } \\
(\%)\end{array}$ & $\begin{array}{c}\text { Vegetációs } \\
\text { alapú } \\
\text { tájbeosztás (\%) }\end{array}$ & $\begin{array}{c}\text { LANMAP } \\
(\%)\end{array}$ & $\begin{array}{c}\text { Szegmentált } \\
\text { táji egységek } \\
(\%)\end{array}$ \\
\hline $\begin{array}{c}\text { Tradicionálisan } \\
\text { definiált kistájak } \\
(\%)\end{array}$ & - & $\mathbf{3 5 , 1 2}$ & 31,19 & 34,00 \\
\hline $\begin{array}{c}\text { Vegetációs alapú } \\
\text { tájbeosztás (\%) }\end{array}$ & $\mathbf{4 0 , 7 2}$ & - & $\mathbf{3 3 , 1 4}$ & $\mathbf{6 6 , 3 3}$ \\
\hline LANMAP (\%) & 28,02 & 25,68 & - & 30,25 \\
\hline $\begin{array}{c}\text { Szegmentált táji } \\
\text { egységek (\%) }\end{array}$ & 33,33 & 33,27 & 33,01 & - \\
\hline
\end{tabular}

Az 5.5. táblázat a Magyarországra vonatkozó négy tájfelosztás néhány kulcs fontosságú tulajdonságait mutatja be. Abban az esetben, ha a felosztás módja szubjektív szegmentáció, pl. a botanikusok által felhasznált szakmai tudás szignifikánsan javította a szegmentált tájak (vegetációs alapú tájbeosztás egységeinek) minőségét. A tradicionálisan definiált kistájak felosztásában és a Vegetációs tájbeosztásban hasonló tényezőket és módszereket használtak fel. Ezen két szubjektív szegmentációra igaz, hogy a tájfelosztás során terepi felméréseket is figyelembe vettek, a felosztások automatikusan és viszonylag gyorsan nem ismételhetőek meg.

Összehasonlítva a négy országos tájfelosztást, a tradicionális felosztásban használtak fel a legkevesebb tájalkotó tényezőt. A LANMAP és az általam szegmentált táji egységek is objektív szegmentáció eredményei, így - a megfelelő adatok és módszer leírás birtokában megismételhetőek.

A két objektív szegmentációval készült tájfelosztás alapján megállapítható, hogy a szegmentált táji egységekben több tájalkotó tényezőt használtam, emellett a térbeli felbontás is nagyobb, mindezek azt eredményezték, hogy a szegmentált táji egységek kisebbek, alakjuk összetettebb, egy-egy egység homogénebb területeket tartalmaz, megfelelnek egy közepes méretarányú tájfelosztásnak. 
5.5. táblázat: A négy magyarországi tájfelosztás legfontosabb tulajdonságai

\begin{tabular}{|l|c|c|c|c|}
\hline & $\begin{array}{c}\text { Tradicionálisan } \\
\text { definiált } \\
\text { kistájak }\end{array}$ & $\begin{array}{c}\text { Vegetációs alapú } \\
\text { tájbeosztás }\end{array}$ & LANMAP & $\begin{array}{c}\text { Szegmentált } \\
\text { táji egységek }\end{array}$ \\
\hline $\begin{array}{l}\text { Táji egységek } \\
\text { száma }\end{array}$ & 230 & 109 & 160 & 261 \\
\hline Méretarány & $1: 100.000$ & $1: 200.000$ & $1: 1.000 .000$ & $\mathbf{1 : 1 0 0 . 0 0 0}$ \\
\hline $\begin{array}{l}\text { Felhasznált } \\
\text { tájalkotó tényezők } \\
\text { száma }\end{array}$ & $\begin{array}{c}\text { területenként } \\
\text { különbözö: 3-4 }\end{array}$ & $\begin{array}{c}\text { területenként } \\
\text { különbözö 3-6 }\end{array}$ & 4 & $\mathbf{6}$ \\
\hline $\begin{array}{l}\text { Tartalmaz terepi } \\
\text { felmérést? }\end{array}$ & Igen & Igen & Nem & Nem \\
\hline $\begin{array}{l}\text { A felosztás } \\
\text { megismételhető? }\end{array}$ & Nem & Nem & Igen & Igen \\
\hline
\end{tabular}

\subsection{2. Összehasonlító elemzés a fuzzy logika alkalmazásával}

A tradicionálisan definiált kistájak és a szegmentált táji egységekre 3.2. A táj kiterjedésének elemzése fuzzy logikával fejezetben bemutatott megközelítés eredménytérképeit mutatja be az 5.6. ábra. A tradicionálisan definiált kistájaknál az összterület 30,51\% tartozik csak a táji magok halmazába, míg 41,92 \% tartozik az átmeneti zónák halmazába (összefüggően akár több kistáj egész területe). Az összterület 27,58\%-a alkotja csupán a határzónák halmazát (fuzzy érték: 0,3-0,7). A szegmentált táji egységek esetében a határzónák halmaza kisebb területet fed le $(21,37 \%)$.

Ez a fuzzy elemzés is rávilágított arra, hogy különösen a határ zónák és a mag zónák halmazaiban, új és jobban illeszkedő és használhatóbb tájfelosztást hoztam létre az objektív többváltozós szegmentációval, illetve az ökoton zónák helyének és méretének azonosításához a fuzzy logika megfelelően alkalmazható módszert nyújthat. 


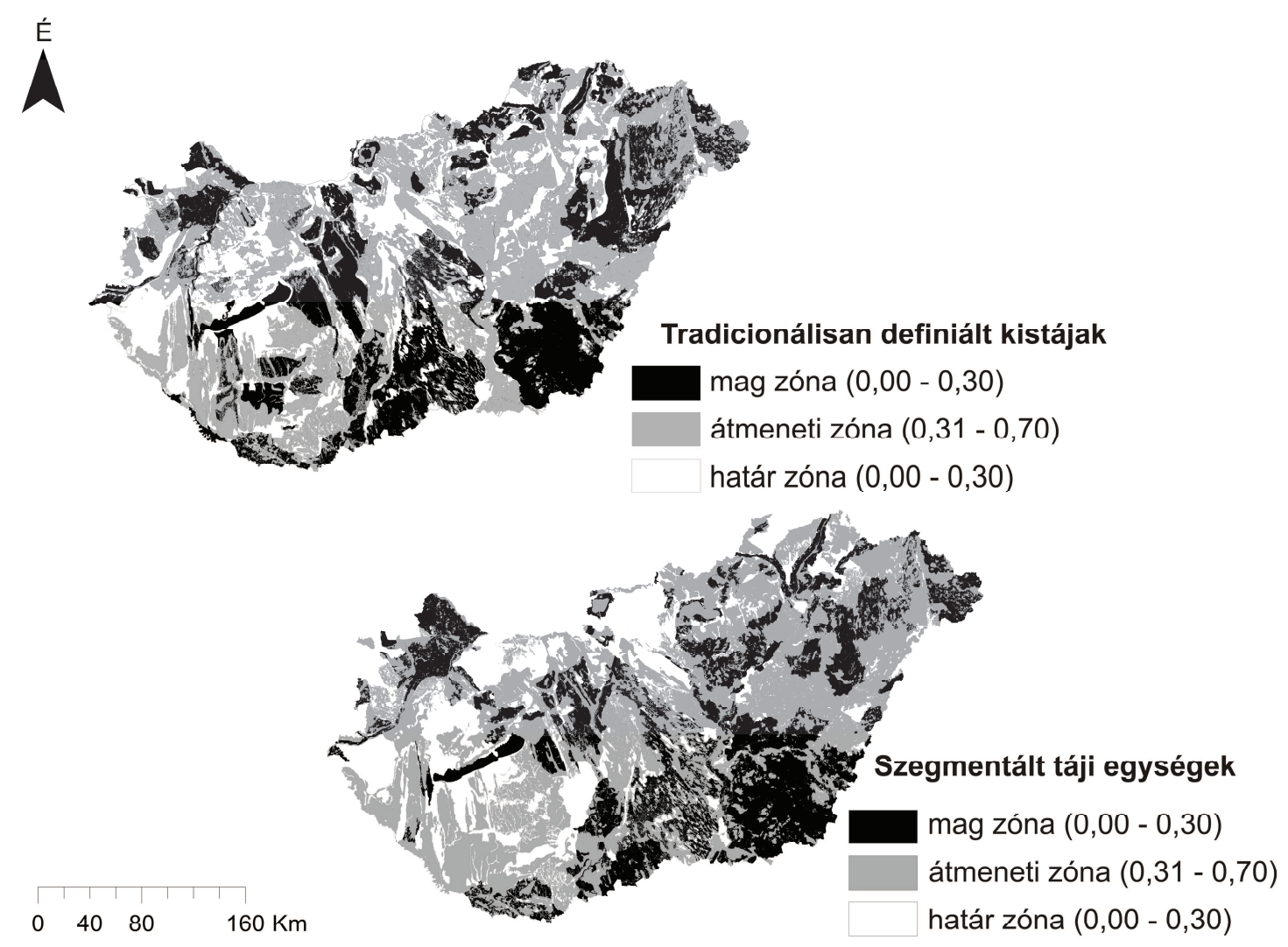

5.6. ábra: A mag zónák, átmeneti területek, illetve a határ zónák a tradicionálisan definiált kistájak és a szegmentált táji egységek felosztásainál

\subsubsection{Regionális összehasonlitó elemzések}

Három jellemző kistájnál összehasonlítottam a szegmentált táji egységek- és a tradicionálisan definiált kistájak határait, melyekhez további tájhatár tájhatár módosítási javaslatokat (lsd. 2.5. A tradicionálisan definiált tájfelosztás bírálatai, módositási javaslatai fejezet) is elemeztem.

\section{a, Kiskunsági-löszöshát}

A Kiskunsági-löszöshát kistáj a Duna Tisza közén elhelyezkedő tipikus alluviális síkság, melyet lösz és homok fed (Dövényi szerk. 2010). A kistáj DNy-i részén a határ egy 4-8 km széles ökoton zónaként értelmezhető. Ez az ökoton zóna a fuzzy értelmezésben a ,határ zóna" halmazba tartozik (fuzzy érték: 0,71-1,00). Az 5.7. ábrán jól látható, hogy a tradicionális felosztásban definiált tájhatár és a szegmentált táji egységek határa egymáshoz közel helyezkedik el. Jelen kistájat a többváltozós szegmentáció több, homogénebb darabra 
osztja fel, föleg azokon a területeken, amelyek a fuzzy logikával történő megközelítésben az „átmeneti zónákhoz” tartoztak. Ezeken a területen, a vegetációs alapú tájbeosztás egységeinek a határa és a szegmentált táji egységek határai nagyon hasonlóak. A két felosztás határai között az átlagos távolság 2,75 km, a legnagyobb távolság $10 \mathrm{~km}$, a legkisebb távolság kevesebb, mint $1 \mathrm{~km}$.

A kapott eredmények alátámasztják, hogy a szegmentált táji egységek jól meghatározottak, erösen támogatják, hogy ezen a területen a tradicionálisan definiált kistájak határai módosításra szorulnak, mint ahogy azt más szerzők is javasolták (Molnár et al. 2008, Deák 2010). Az objektív, többváltozós szegmentáció folyamata megfelelő módszere lehet egy új tájlehatárolás elkészítésének.
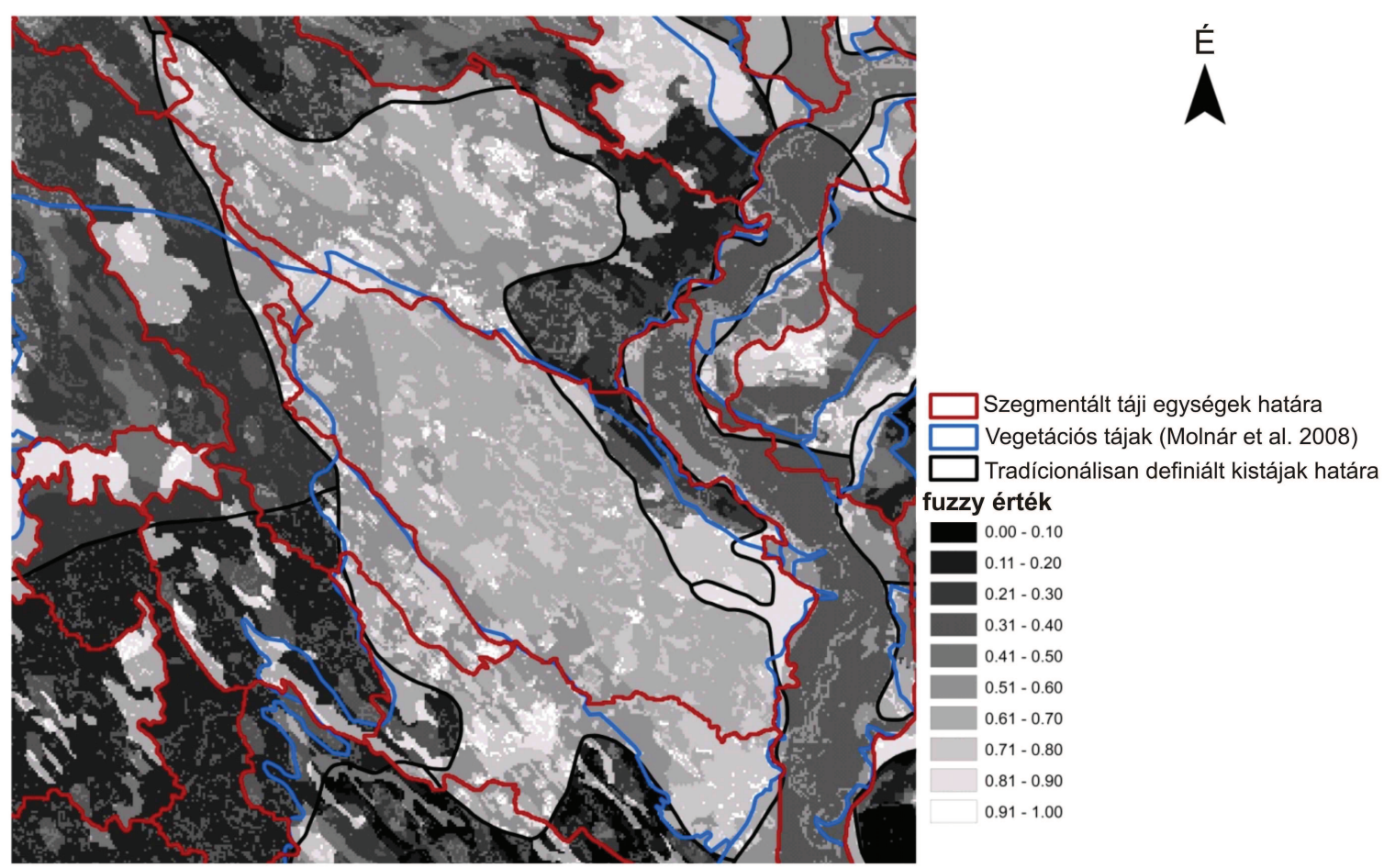

$02,55 \quad 10 \mathrm{Km}$

5.7. ábra: A különböző tájfelosztások összehasonlítása a Kiskunsági-löszöshát kistáj területén

\section{b, Illancs}

Az Illancs kistáj keleti fele 20-30 m vastag homokkal fedett, míg a déli határ mentén löszt találhatunk (Dövényi szerk. 2010). A kistáj határának módosított változatához terepi bejárást, vizsgálatokat is felhasználtak a területhasználati -, talaj - és növényzetborítási tulajdonságok mellett (Ladányi 2010). 
Az alkalmazott fuzzy logika szerint az ÉNy-i és DK-i határokat ökoton zónaként értelmezhetjük, az ÉNy-i határ mentén ez a zóna mintegy 3-5 km-es szélességü (5.8. ábra). A kistáj területén a szegmentált táji egység határának több szakasza igen közel húzódik a Ladányi (2010) által javasolt új kistáj határhoz, ezeken a szakaszokon a két változat átlagos távolsága kevesebb, mint $1 \mathrm{~km}$. Összehasonlítva a szegmentált táji egységet a fuzzy elemzés eredményével, nyilvánvalóvá vált, hogy a kistáj É-i részén a határ vonala északabbra tolódott, ugyanúgy, mint a Ladányi (2010) által javasolt módosításban.

Összességében elmondható, hogy a szegmentált táji egység határa nagymértékben hasonlít az összetett tájökológiai kutatás eredményéhez (Ladányi 2010). Megállapítható, hogy az objektív többváltozós szegmentáció megfelelően alkalmazható a tájlehatárolásra e kistáj területén is.

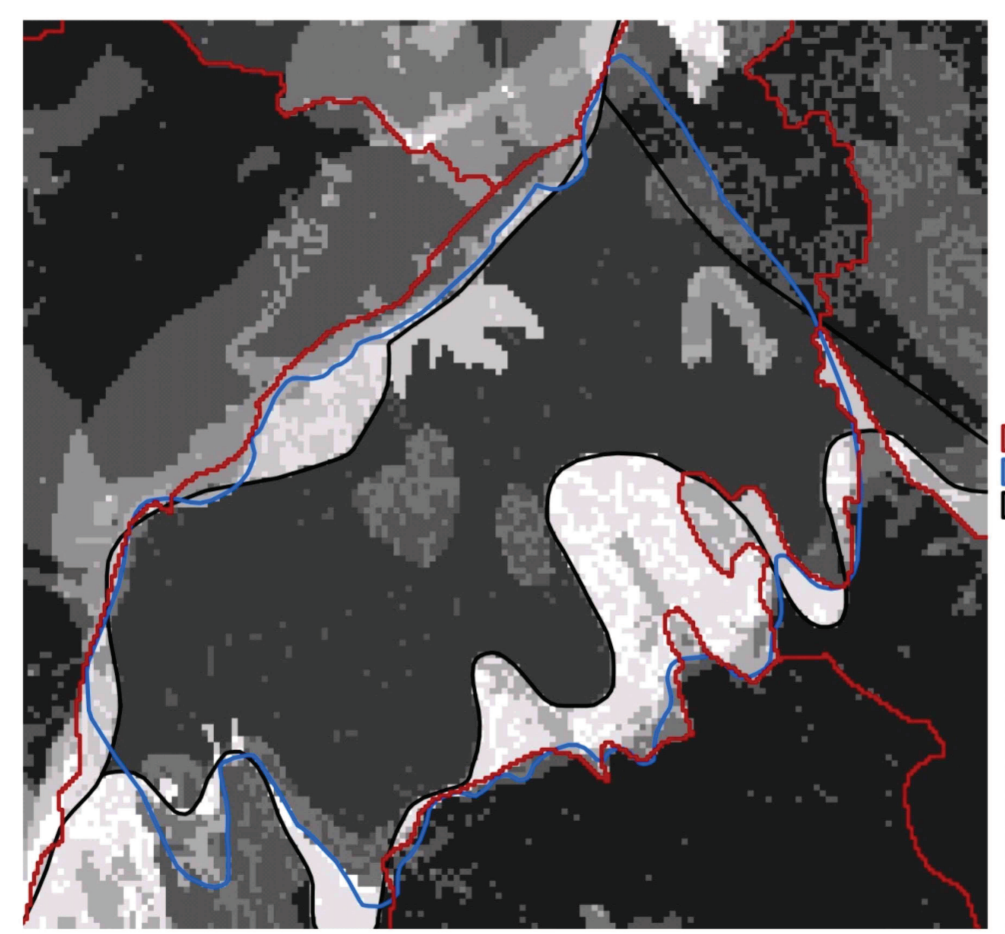

$\begin{array}{llll}0 & 1 & 2 & 4 \\ \mathrm{Km}\end{array}$

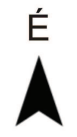

$\square$ Szegmentált táji egységek határa Módosított tájhatár (Ladányi 2010) Tradícionálisan definiált kistájak határa

\section{fuzzy érték}

$0.00-0.10$

$0.11-0.20$

$0.21-0.30$

$0.31-0.40$

$0.41-0.50$

$0.51-0.60$

$0.61-0.70$

$0.71-0.80$

$0.81-0.90$

$0.91-1.00$

5.8. ábra: A különböző tájfelosztások összehasonlítása az Illancs kistáj területén

c, Dél-Tisza-völgy

A Dél -Tisza-völgy kistáj a Tisza alluviális síkságának déli területén helyezkedik el. Felszínét az aktív és egykori vízfolyások formái (pl. morotva) is taglalják. A kistáj É-i területére az eolikus akkumulációs formák (pl. homokdủnék és homoklepel) is jellemzőek (Dövényi szerk. 2010). A Dél-Tisza-völgy kistáj területére tájhatár módosítási javaslatokat komplex tájökológiai kutatásokat (vizsgált tájöklógiai tényezők pl.: talaj, vegetáció: terepi felméréseken készítet élőhely térképek) követően tettek (Deák 2010). 
A fuzzy elemzés szerint a kistáj területe többnyire az „átmeneti zónák” halmazába tartozik (fuzzy érték: 0,31-0,70), melyben egy új tájlehatárolás segítene a terület hovatartozásának meghatározásában (5.9. ábra). A fuzzy - és a komplex tájökológiai elemzés szerint is ezen a területen több táji egységet kellene elkülöníteni. A területre eső szegmentált egységek határszakaszainak egy része közel helyezkedik el a javasolt tájhatár módosításokhoz. A kettő tájlehatárolás közt az átlagos távolság kisebb, mint 1,5 km, mely elfogadható a vizsgált 1:100 000-es méretarány mellett. Ebben a síksági, folyóvidéki területen több kisebb táji egységet különített el az objektív, többváltozós szegmentáció, mely e kistáj lehatárolásának is alkalmazható módszere lehet.

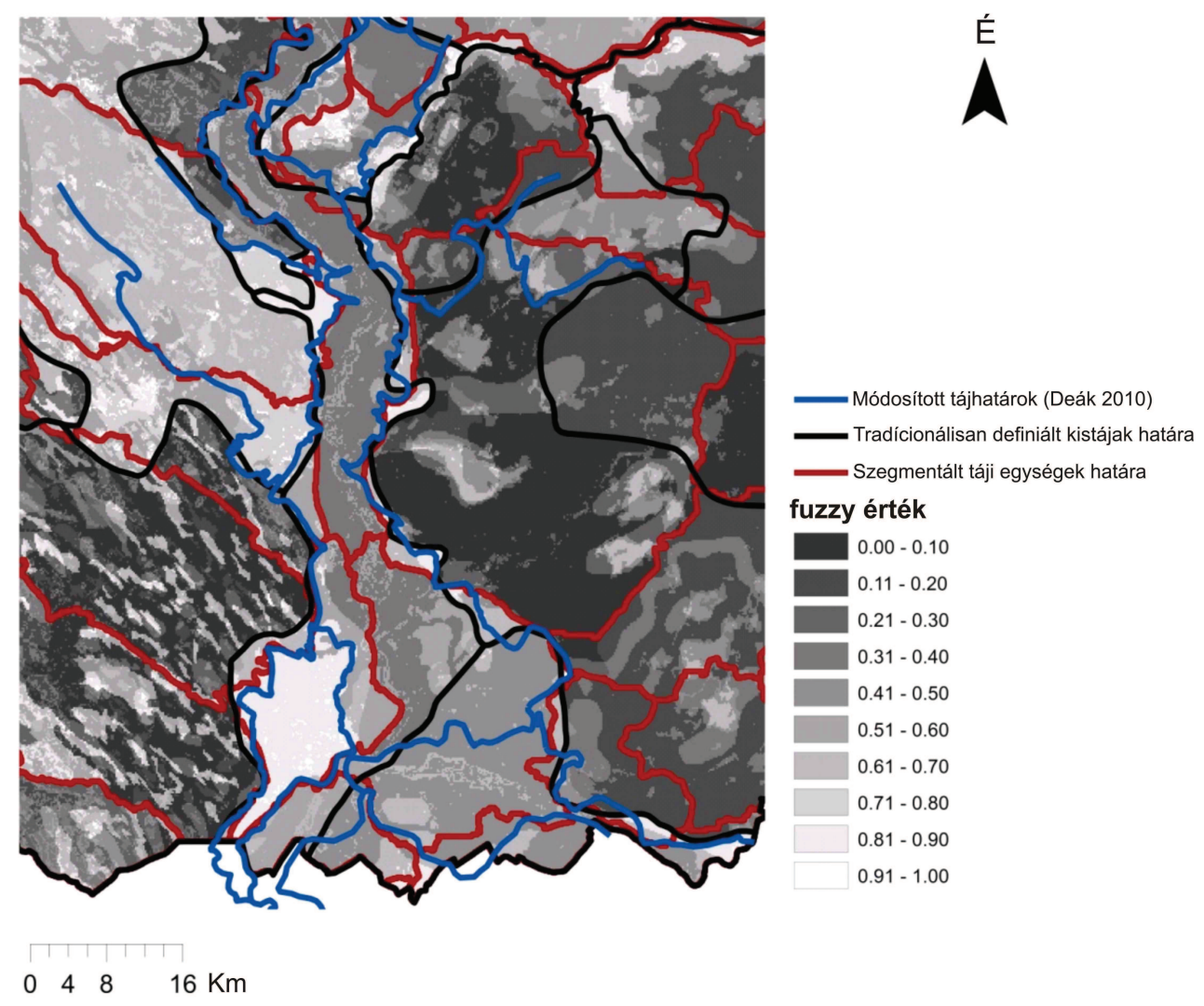

5.9. ábra: A különböző tájfelosztások összehasonlítása a Dél-Tisza-völgy kistáj területén

\subsection{A mesterséges gátak okozta tájfelszabdaltság változásának eredményei}

Annak érdekében, hogy képet lehessen kapni a tájak, tájak határainak érzékenységéről, stabilitásáról megvizsgáltam a mesterséges gátak (utak, vasutak és települések) okozta tájfelszabdaltság térbeli és 1990 és 2011 közötti, időbeli változásait különböző tájmetriai mérőszámok kiszámításával (lsd. 3.3. A tájak- és határaik érzékenységének vizsgálata (a mesterséges gátak okozta tájfelszabdaltság függvényében) fejezet). E mellett elemeztem, hogy milyen állapotok várhatóak a 2027-re tervezett gyorsforgalmi - és fóúthálózat nagytávú 
fejlesztési terv megvalósulása esetén. Vizsgáltam, hogy mely kistájak esetében várható az, hogy a vizsgált mesterséges gátak létesítése negatív irányú változást idézhet elő, a csökkentve azok ökológiai stabilitását, növelve érzékenységüket.

\subsubsection{A mesterséges gátak változásai 1990 és 2011 között}

Első lépésben megvizsgáltam, hogy hogyan fejlödött a közlekedési infrastruktúra (út- és vasúthálózat) illetve az települések belterületi kiterjedése miként változott a vizsgált időszakban: 1990-2011 között, így képet kaptam arról, hogy hol milyen mesterséges gátak létesítése, illetve kiterjedésének változása okozhatott tájfelszabdalódást.

\subsubsection{1. Úthálózat változása, fejlödése}

A Térkép Kft térinformatikai adatbázisa a 2011-es úthálózat állapotát tartalmazza (Térkép Kft 2011), e mellett felhasználva a 1990-es OTAB (1:100 000-es méretarányú) útvonalhálózatot (lsd. 4. Vizsgált terület, adatok fejezet), kiszámítottam az útvonalhálózat 1990-2011 közötti fejlödését, pontosabban kibővítését (5.6. táblázat).

5.6. táblázat: Az úthálózat hosszának változása 1990 és 2011 között

\begin{tabular}{|l|c|c|c|}
\hline & $\begin{array}{c}\text { Útvonalhossz összesen (km) } \\
\mathbf{1 9 9 0}\end{array}$ & $\begin{array}{c}\text { Útvonalhossz összesen (km) } \\
\mathbf{2 0 1 1}\end{array}$ & $\begin{array}{c}\text { Változás } \\
\mathbf{( k m )}\end{array}$ \\
\hline Autópálya & 953,99 & 3042,88 & $+\mathbf{2 0 8 8 , 8 9}$ \\
\hline Fő́t & 6791,79 & 7234,60 & $+\mathbf{4 4 2 , 8 1}$ \\
\hline Mellékút & 53420,78 & 53535,45 & $+\mathbf{1 1 4 , 6 7}$ \\
\hline Összesen: & $\mathbf{6 1 1 6 6 , 3 4}$ & $\mathbf{6 3 8 1 2 , 9 3}$ & $+\mathbf{2 6 4 6 , 3 7}$ \\
\hline
\end{tabular}

Az 1990 és 2011 között épített úthálózat közel 79 \%-a autópálya, mely a három típusból a legnagyobb területet fedi le a tájból, a felhajtók illetve lehajtók pedig olyan tájökológiai foltot határolnak le ( maradványfoltok), amelyeknek egy mással vagy a mátrix-szal nincs ökológiai kapcsolódási lehetősége (5.10. ábra). 


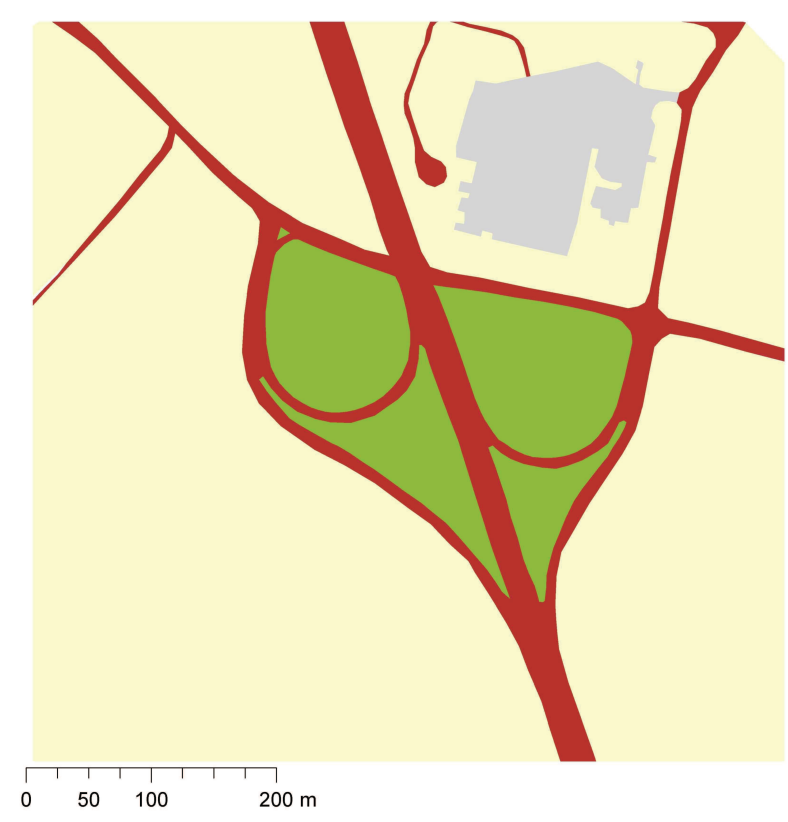

$\stackrel{\mu}{\Lambda}$

tájalkotó elemek

mesterséges ökológiai gát

maradványfolt

mesterséges tájfolt

mátrix

5.10. ábra: Tájalkotó elemek az M5 -ös autópálya egyik fel - és lehajtójának megépítése után Kiskunfélegyháza határában

Az autópályák mellett a vizsgált időszakban föként foút rangú elkerülő utakat építettek a települések köré. Ezek az elkerülö utak (5.11. ábra) a potenciálisan legnagyobb tájszabdaló hatással bírnak, hiszen nemcsak „vonalas” objektumok, hanem alakjukat tekintve ívesek is (viselkedésük ökológiailag hasonló az autópályák fel-le hajtókhoz). Egy létező úthoz kapcsolódva (kezdő és végpontjait tekintve is), többnyire a települések belterületi határán kívül létesítik őket, így nagyobb eséllyel különítenek el egy darabot a tájból, mint egy hosszú szakaszon keresztül egyenesen húzódó út.
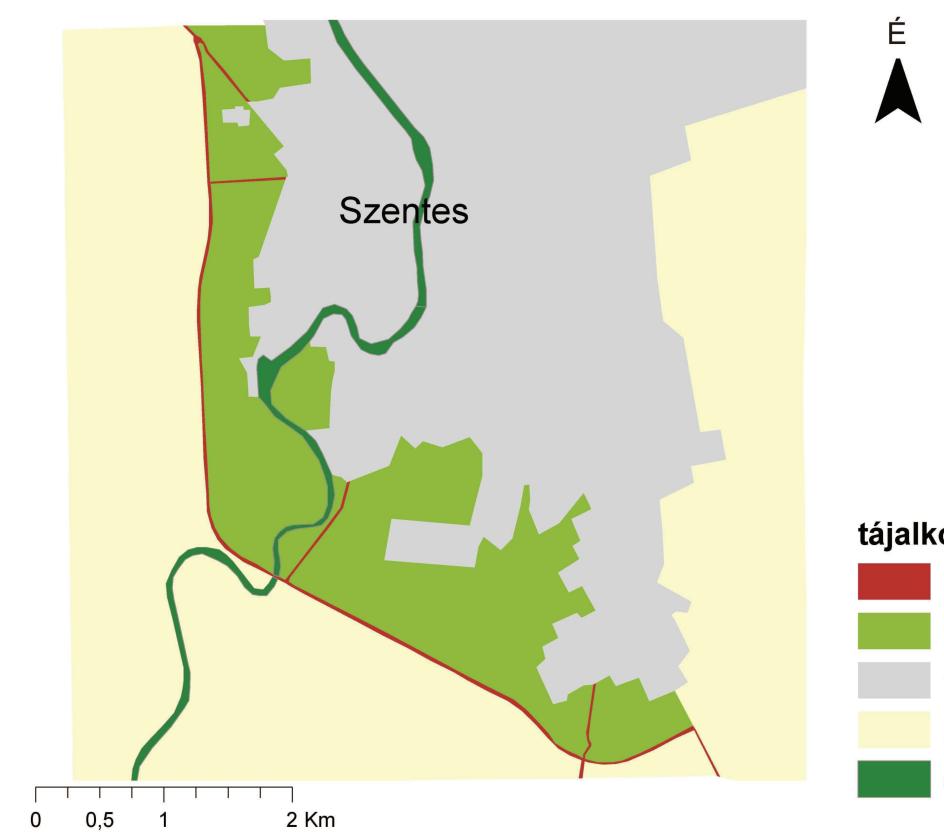

\section{tájalkotó elemek}

mesterséges ökológiai gát

maradványfolt

mesterséges tájfolt

mátrix

ökológiai folyosó

5.11. ábra: Tájalkotó elemek a szentesi elkerülő út megépítése után 


\subsubsection{Vasúthálózat változása}

A vizsgált időszakban (1990-2011) új vasútvonalat nem létesítettek, ezáltal ilyen típusú mesterséges gát nem szabdalta tovább a tájat. Általánosságban elmondható, hogy Magyarországon a vasúthálózat fejlesztések során, nem új vasút vonalakat létesítenek, hanem a meglévőeket korszerüsítik, villamosítják, újabb megállóhelyeket építenek. (Vasútvonal fejlesztések 2011). Egyes szakaszokon a vasúti közlekedést leállították, ennek ellenére e szakaszok továbbra is mesterséges gátként funkcionálhatnak.

\subsubsection{Települések belterületének változása}

A 4. Vizsgált terület, adatok fejezetben már említett módon a települések tekintetében nem sikerült egy olyan egységes adatbázist létrehoznom, melyben az adatok térbeli pontossága megegyezik. Ennek oka, hogy jelenleg nincs olyan egységes adatbázis, mely a települések belterületi határait tartalmazná az 1990-es és az 2011-es időszakból is, a különböző adatbázisok összehasonlításában nem egyszerü a térbeli pontatlanság kiküszöbölése, mivel a vizsgált időszakban, ha összehasonlítjuk a két adatbázis alapján a települések méretét és helyzetét, nem minden területnövekedés tudható be a fejlödés okozta növekedésnek, ez a két adatbázis közti térbeli pontatlanság (digitalizálási hiba) is lehet.

Ezért a települések belterületének változásakor a két adatbázis állományából képzett átlagos területi különbség alapján egy 24, 63 ha-os hibával számoltam, vagyis az ez alatti változásokat kizártam az elemzésekből.

Ennek alapján a vizsgált időszakban a legnagyobb területnövekedéssel rendelkező öt település rendre: Miskolc, Érd, Debrecen, Győr és Tiszaújváros. Ezen városokon kívül tizenkét olyan város található Magyarországon, melynek növekedése a vizsgált időszakban meghaladta a $10 \mathrm{~km}^{2}$-es értéket.

\subsubsection{A tradicionálisan definiált kistájak felszabdaltságának változása a vizsgált mesterséges gátak hatására 1990 és 2011 között}

A tájfelszabdaltság múltbéli változásának feltárására, illetve a közepes méretarányú tájökológiai egységek határainak érzékenységének, stabilitásának vizsgálatához kiszámoltam a 3.3. A tájak- és határaik érzékenységének vizsgálata (a mesterséges gátak okozta tájfelszabdaltság függvényében) fejezetben bemutatott felszabdaltság mutatókat kistájanként az 1990-es bázisévre és a 2011-es állapotra. A vizsgálat során a mesterséges gátak közül az 
út-, vasút- és településhálózatokkal dolgoztam az OTAB adatbázis és a Térkép Kft. térinformatikai állományából készített adatbázis alapján (lsd. 19. sz. melléklet).

A ,Foltok száma” (NP) kivételével a kiszámított többi mutatót (S, D, Mesh $\left.{ }_{\mathrm{CUT}}\right)$ az elmúlt évtizedben fejlesztették ki (Jaeger 2000, Moser et al. 2007), ezek a hagyományos paraméterekhez képest, újabb, több információt szolgáltatnak a tájak felszabdaltságáról, érzékenységéröl (Jaeger 2002).

A kiszámolt, felszabdaltságok jellemző legegyszerübb metrikai mutató a „Foltok száma” (NP). A vizsgált 1990-2011 közötti időszakban százöt kistájon belül nem tapasztaltam a foltszámot tekintve változást, kilencvenöt kistáj esetében mértem foltszám növekedést (5.12. ábra).

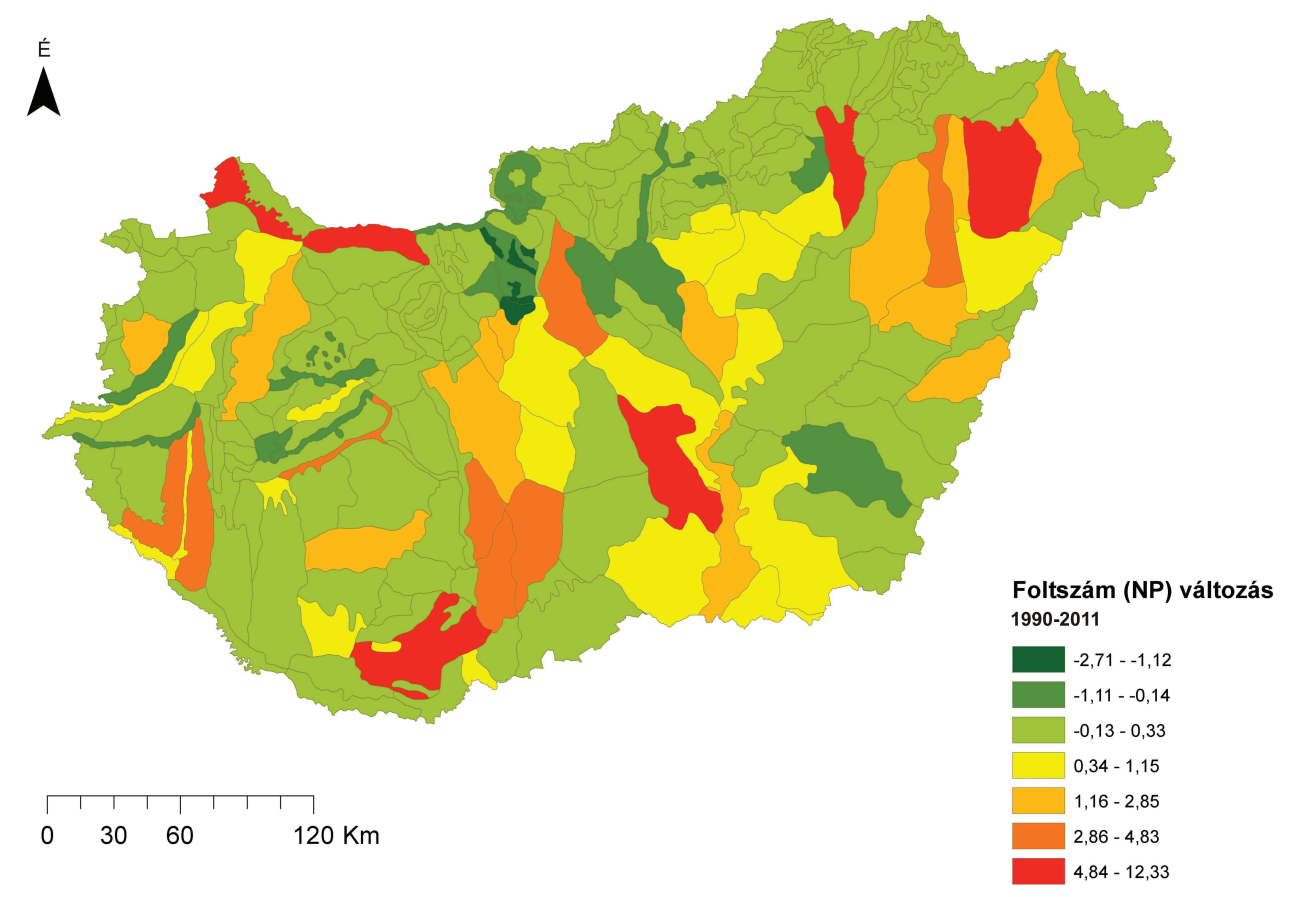

5.12. ábra: A kistájakon belüli Foltok számának változása 1990 és 2011 között (a mesterséges gátak okozta tájfelszabdaltság függvényében)

Minél több mesterséges gátat létesítenek az adott kistájon belül oly módon, hogy az érintkezzen (legalább két pontban) más meglévő mesterséges gáttal, a „Foltok száma” annál nagyobb lesz. E mutató szerint a legfelszabdaltabb, legnagyobb változással érintett öt kistáj rendre: Pesti - hordalékkúpsíkság (+99), Tolnai-Sárköz (+66), Közép-Mezőföld (+64), SajóHernád-sík (+52), Dél-Baranyai-dombság (+45). 


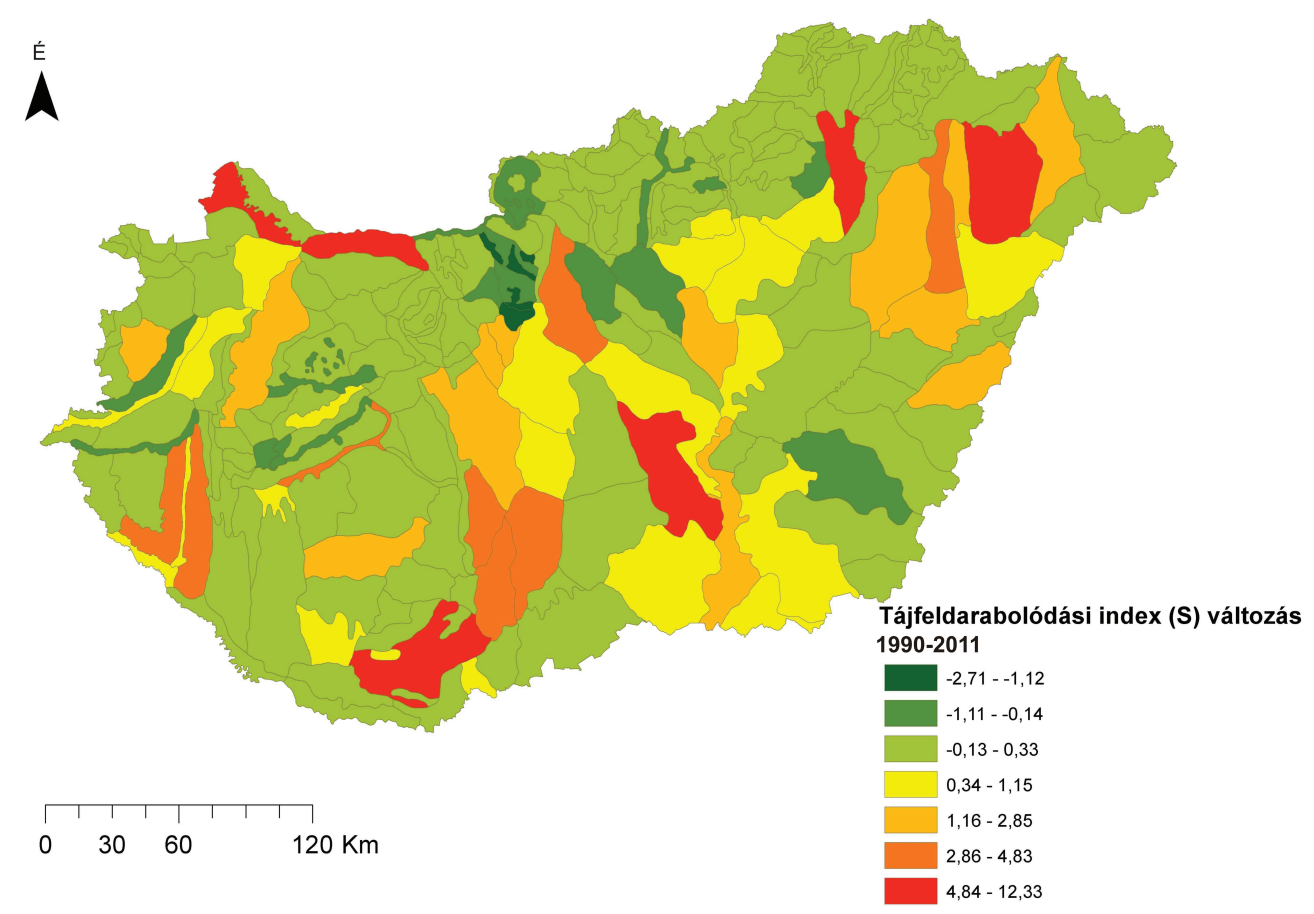

5.13. ábra: A kistájakon belüli Tájfeldarabolódási index változása 1990 és 2011 között (a mesterséges gátak okozta tájfelszabdaltság függvényében)

Újabb vonalas közlekedési hálózati elem létrehozásakor, az egy már létező elemet oly mértékben keresztezheti, hogy kivág egy darabot a korábbi tájrészletből, akkor ez a tájfelszabdalásban a „Foltok számának” növekedésében egyértelműen kimutatható, ugyanakkor a „Foltok száma” (NP) tájmetriai mutató ennél több információt nem szolgáltat a felszabdaltság tulajdonságairól, esetleges kockázatairól.

A „Foltok száma” mutatónál több információt hordoz a felszabdaltság változásának tulajdonságairól pl. a „Tájfeldarabolódási index” (S). E mutató szerint ötvennégy kistáj esetében nem történt felszabdalódás a tekintetében, hogy az ugyanakkora valószínűség mellett értelmezett egyenlő méretü foltok száma nem változott (5.13. ábra). A „Foltok száma” (NP) mutató eredményével részben egyezik, hogy az öt leginkább felszabdalt kistáj: Győr-Tatai teraszvidék (+12,33), Közép-Nyírség $(+9,4)$, Sajó-Hernád-sík $(+9,01)$, Dél-Baranyai dombság $(+8,82)$ és a Mosoni-sík $(+8,12)$. Vagyis a Sajó-Hernád-sík és a Dél-Baranyai dombság mindkét mutató esetében az őt legfelszabdaltabb kistájak listájában szerepel.

Kiemelve egy példát: Győr-Tatai teraszvidék kistáj esetében a mesterséges gátak okozta táj felszabdaltsága akkor méretet öltött, hogy míg 1990-ben 11,74 egyenlő méretü foltra lehetett felosztani a kistájat, 2011-ben ez az érték már 24,07 („Foltok száma”(NP) mutató tekintetében +10 -es értéknövekedés). A Győrt elkerülő közel 10 km hosszú M1 autópályaszakasz, illetve a nagyobb települések (Györ, Tata, Komárom) növekedésének hatására a kistájat több mint kétszer annyi egyenlő méretű foltra kell felosztanunk ahhoz, hogy ugyanazon valószínűség mellett két élőlény megtalálja egymást a vizsgált egységen belül (lsd. 
3.3. A tájak- és határaik érzékenységének vizsgálata (a mesterséges gátak okozta tájfelszabdaltság függvényében) fejezet - a „Tájfeldarabolódási index”definíciója).

A kiszámolt „Hatékony hálóméret” (Mesh ${ }_{\mathrm{CUT}}$ ) változását a vizsgált időszakban az 5.14. ábra mutatja be. A hibaküszöb figyelembevételével ötvennégy kistáj esetében nem tapasztalhatunk „,Hatékony hálóméret ${ }_{C U T}$ ” változást.

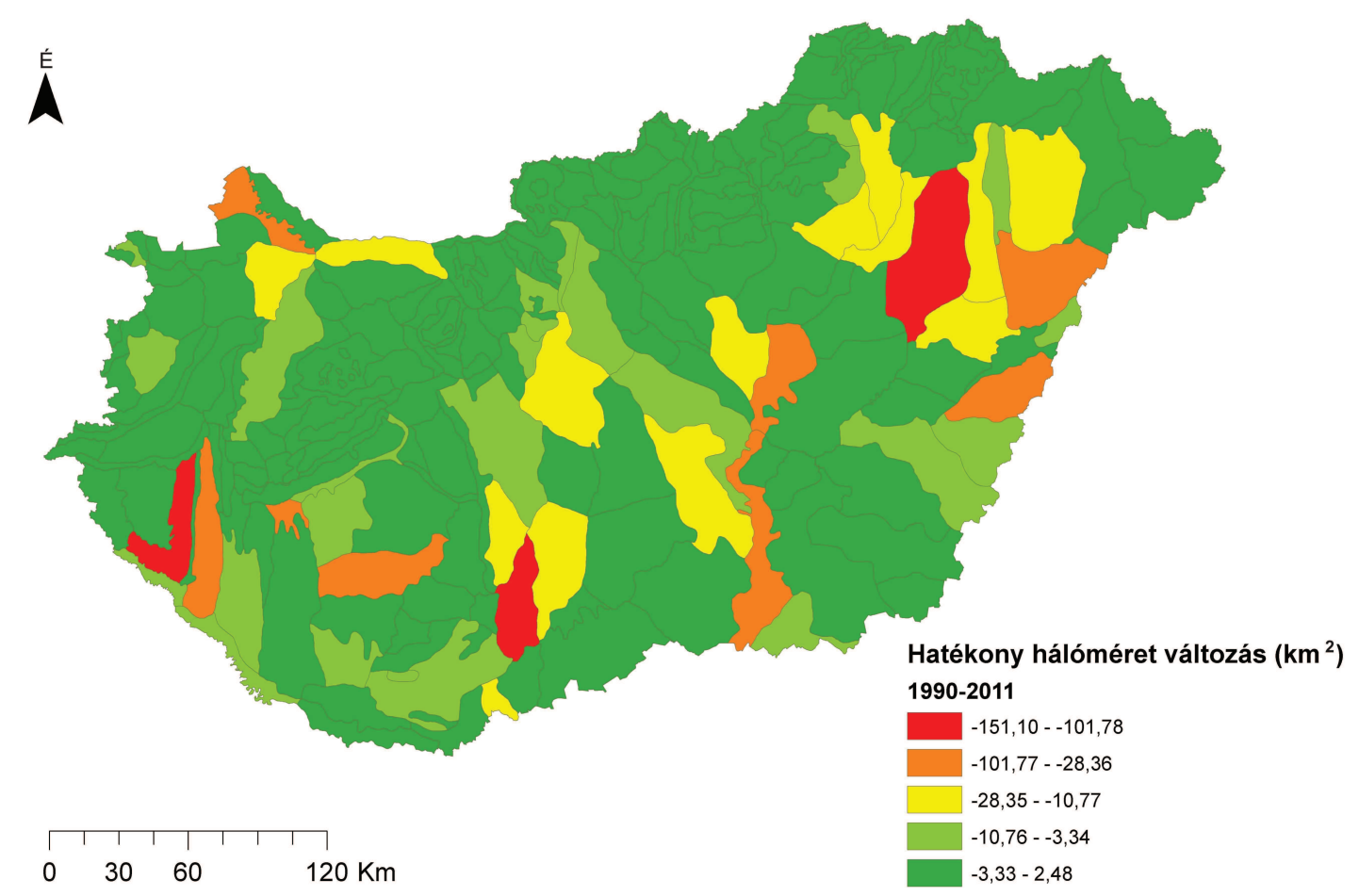

5.14. ábra: A kistájakon belüli Hatékony hálóméret CUT változása 1990 és 2011 között (a mesterséges gátak okozta tájfelszabdaltság függvényében)

Az élőhelyek számára „hatékonyan” felhasználható területet tekintve a legkedvezőtlenebbé az Egerszeg - Letenyei dombság kistáj vált (5.7. táblázat). A kistáj 645,02 $\mathrm{km}^{2}$-es összterületéből 2011-re a „Hatékony hálóméretCUT” 155,93 km²-rel lett kisebb. Megépült a kistájat ÉK-en kettévágó 74-es föút és D-en az M7-es autópálya Nagykanizsa és Letenye közti szakasza is a „Foltok száma” (NP) 18-ról 45-re, a „Tájfeldarabolódási index” (S) értéke 2,56-ról 7,15-re, míg a kistáj „,Felosztottság Foka” (D): 61-ről 86-ra nőtt.

A táj mesterséges gátak okozta felszabdaltsága már itt már oly mértéket öltött, hogy a jövőben a közlekedési hálózati további fejlesztését tájvédelmi szempontból célszerű elkerülni. Abban az esetben, ha ez nem megoldható (lsd. később az 5.4.4. A mesterséges gátakkal felszabdalt kistájak érzékenysége, stabilitása fejezet), akkor nagyobb figyelmet kell fordítani az utak tervezése során a megfelelő minőségü, szélességü ökológiai átjárók (ecoductok) létesítésére. Ezek ideális esetben a fajáramlást akadályozó mütárgyak átjárhatóságát újra lehetővé teszik. 
$100 \mathrm{~km}^{2}$-es nagyobb „Hatékony hálóméret ${ }_{C U T}$ " csökkenést további két kistájunk esetében kapunk (5.7. táblázat). A Tolnai- Sárköz kistájat K-Ny-i irányban kettévágja az M9-es autóút és É-D-i irányban az M6-os autópálya is, mely jelen kistájban négy db fel- és lehajtóval is rendelkezik, mely még inkább továbbszabdalja a tájat, mindemellett, Alsónyék település É-i részén megépült az 55-ös föút elkerülő szakasza is.

5.7. táblázat: 1990 és 2011 között legnagyobb mértékben felszabdalt három kistáj tájmetriai mutatóinak eredményei

\begin{tabular}{|l|c|c|c|c|}
\hline \multicolumn{1}{|c|}{ Kistáj neve } & $\begin{array}{c}\text { NP változás } \\
(\mathbf{d b})\end{array}$ & $\begin{array}{c}\text { S változás } \\
(\mathbf{d b})\end{array}$ & $\begin{array}{c}\text { D változás } \\
(\%)\end{array}$ & $\begin{array}{c}\text { Mesh } \\
\text { CUT változás } \\
\left(\mathbf{k m}^{2}\right)\end{array}$ \\
\hline $\begin{array}{l}\text { Egerszeg-Letenyei } \\
\text { dombság }\end{array}$ & +27 & $+4,59$ & $+25,08$ & $-155,1$ \\
\hline Tolnai-Sárköz & +62 & $+3,83$ & 21,24 & $-133,74$ \\
\hline Hortobágy & +19 & $+1,54$ & 6,15 & $-101,78$ \\
\hline
\end{tabular}

A Hortobágy kistájat felszabdaló elemek: M3 autópálya Polgár-Hajdúnánás közti több mint 55 km-es szakasza, a 35-ös fóút, mely becsatlakozik az autópályához a kistáj közepén Hajdúböszörmény felé, illetve egy elkerülőt építettek Polgár település K-i oldalán (5.15. ábra).

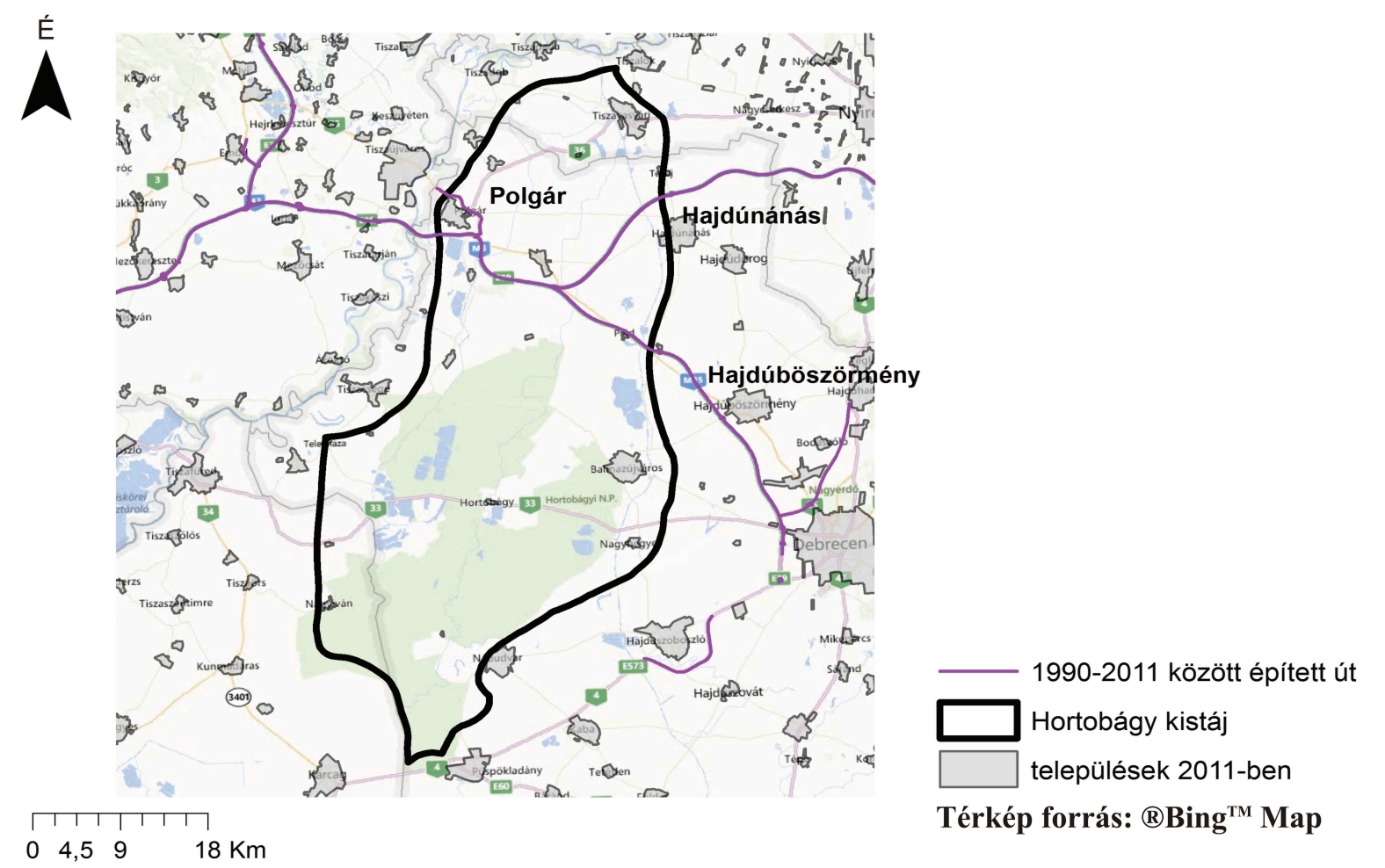

5.15. ábra: A tájfelszabdaltságot okozó új utak a Hortobágy kistáj példáján 
Az elemzés eredményeképp a hibaküszöb figyelembevételével „Hatékony hálóméret növekedést is tapasztalhatunk 24 kistájnál. A növekedések maximuma $247,79 \mathrm{~km}^{2}$, átlaga $75,23 \mathrm{~km}^{2}$.

A „Hatékony hálóméret ${ }_{C U T}$ " növekedések egyik oka, hogy a települések területi növekedése olyan mértékűvé és irányúvá vált, hogy elérte a környező utak hálózatát és azokon túl is terjedt, így az élőhely területének alakja megváltozott, a felszabdalt „Foltok száma” csökkent, a „Hatékony hálóméret ${ }_{C U T}$ ” értéke nőtt (pl. Tolnai hegyhát kistáj). Az „Hatékony hálóméret ${ }_{C U T}$ ” növekedés másik oka abban keresendő, hogy előfordulhat olyan eset is, hogy az adott kistájban található település mérete a vizsgált 1991-2011 közötti időszakban csökkent, illetve harmadik előfordulható eset a két előző ok együttes megjelenése is. Az biztosan állítható, hogy a jelenség előfordulásában az utak - és vasutak hálózatának csökkenése nem játszik szerepet, mivel ilyen a vizsgált időszakban nem történt. Következtetésként megállapítható, hogy e jelenség okainak feltárására, minden érintett kistáj esetében további, részletesebb vizsgálatokra lenne szükség (lsd. később az 5.4.4. A mesterséges gátakkal felszabdalt kistájak érzékenysége, stabilitása fejezetben).

\subsubsection{A tradicionálisan definiált kistájak felszabdaltságának várható változása a vizsgált mesterséges gátak hatására 2011 és 2027 között}

A tájfelszabdaltság jövőbeli változásának elörejelzésére, illetve a közepes méretarányú tájökológiai egységek határainak érzékenységének, stabilitásának vizsgálatához kiszámoltam a 3.3. A tájak- és határaik érzékenységének vizsgálata (a mesterséges gátak okozta tájfelszabdaltság függvényében) fejezetben bemutatott felszabdaltság mutatók várható

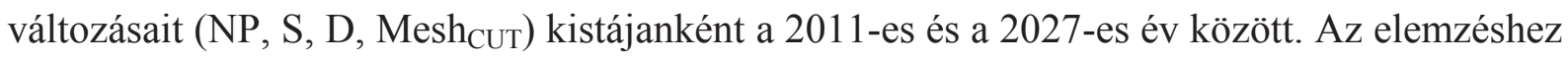
„A gyorsforgalmi - és főúthálózat nagytávú terve” (1222/2011. (VI.29.) Kormányhatározat) megyei térképeiről geokorrigálást követően bedigitalizáltam a 2027-ig tervezett utak nyomvonalait (lsd. 20. sz. melléklet, 5.8. táblázat). Az egységes adatbázist a Térkép Kft. térinformatikai állományából (Térkép Kft 2011) és a bedigitalizált tervezett nyomvonalakból építettem fel. Mivel a települések jövőbeli változására nem léteznek országos tervek így ebben a vizsgálatban minden esetben a települések határai a 2011 állapottal szerepelnek.

A nagytávú terv teljes megvalósulása esetén 2027-re a 2011-es állapothoz képest autópályákból még 490,48 km-nyit terveznek megépíteni (18,53\%). A legtöbb tervezett út fajtája a főút, 2706,52 km-rel több szerepel ebből a tervekben, viszont újabb mellékutak építése a tervekben nem szerepelt. 
5.8. táblázat: Az úthálózat hosszának várható változása 2011 és 2027 között

\begin{tabular}{|l|c|c|c|}
\hline & $\begin{array}{c}\text { Útvonalhossz összesen } \\
(\mathbf{k m})\end{array}$ & $\begin{array}{c}\text { Útvonalhossz összesen } \\
\mathbf{( k m )}\end{array}$ & Változás (km) \\
\hline Autópálya & 3042,88 & $\mathbf{2 0 2 7}$ & \\
\hline Föút & 7234,60 & 3533,36 & $+\mathbf{4 9 0 , 4 8}$ \\
\hline Mellékút & 53535,45 & 9941,12 & $+\mathbf{2 7 0 6 , 5 2}$ \\
\hline Összesen & $\mathbf{6 3 8 1 2 , 9 3}$ & 53535,45 & $\mathbf{0}$ \\
\hline
\end{tabular}

2027-re elörejelezve a mesterséges gátak okozta felszabdaltságot: mindössze 67 kistáj esetére nem tapasztalhatunk „Foltszám” növekedést (5.16. ábra). E mutató szerint várhatóan a legfelszabdaltabb, legnagyobb változással érintett öt kistáj rendre: Békés-sík (+45), Északkelet-Nyírség (+44), Csepeli-sík (+38), Közép-Mezőföld (+34), Csongrádi-sík (+32).

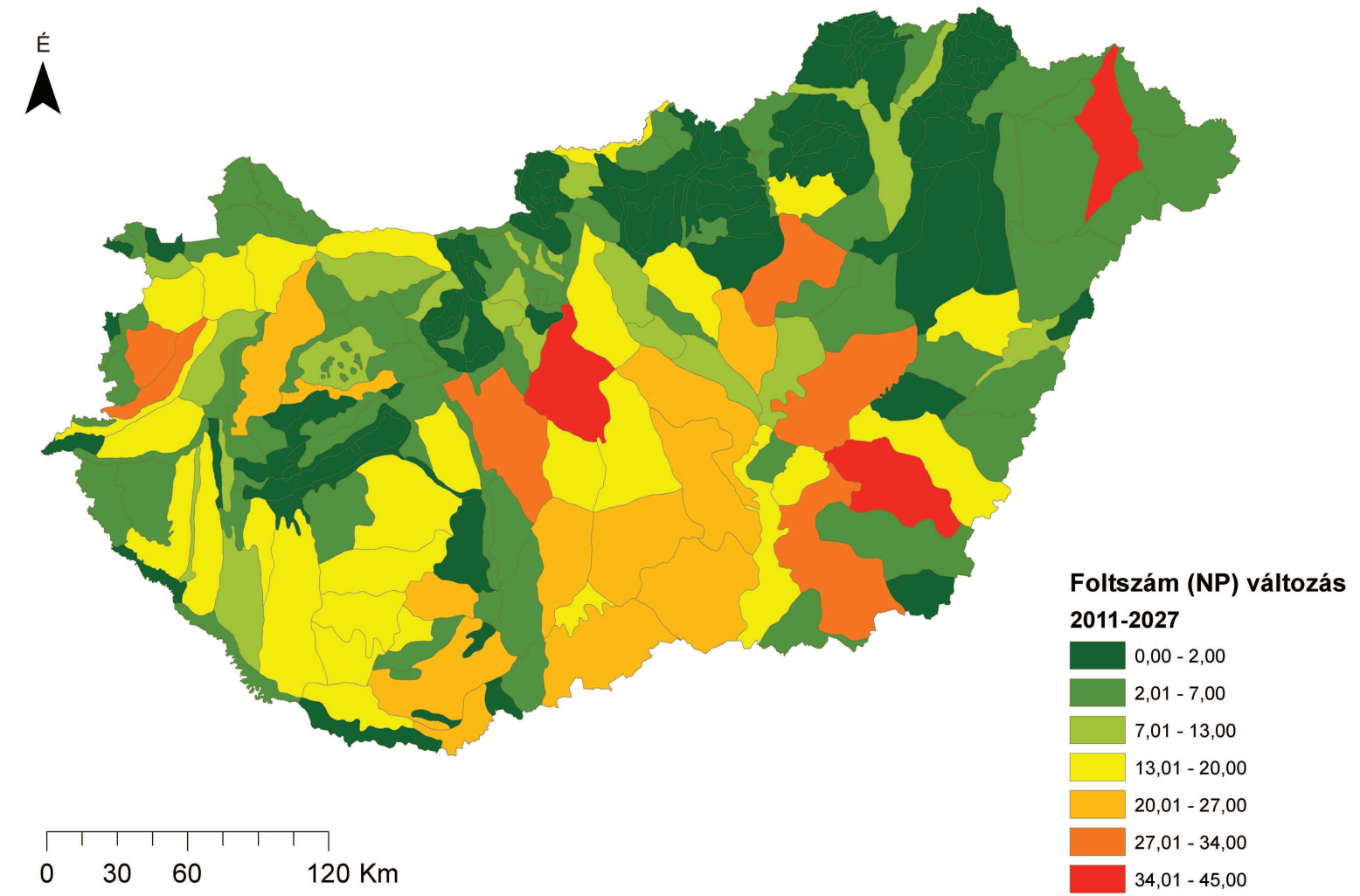

5.16. ábra: A kistájakon belüli foltok számának várható változása 2011 és 2027 között (a mesterséges gátak okozta tájfelszabdaltság függvényében)

A tájak felszabdaltságáról több információt hordozó „Tájfeldarabolódási indexet” (S) tekintve nyolcvankét kistáj esetében nem várható felszabdalódás, az ugyanakkora valószínűség mellett értelmezett egyenlő méretű foltok száma nem fog változni (5.17. ábra). Várhatóan az öt leginkább felszabdalt kistáj viszont: Északkelet-Nyírség $(+18,74)$, FelsőKemeneshát $(+10,09)$, Bácskai-löszös síkság $(+9,68)$, Hatvani - sík $(+7,87)$, Szolnok-Túri sík $(+7,12)$. Az előző mutatóhoz képest az öt leginkább felszabdalt kistáj listája eltérően alakul. 
Ennek oka az, hogy míg a „,Foltszámot” tekintve a leginkább érintett kistáj a Békési - sík volt, viszont közelebbről megvizsgálva jól látható, hogy a kistáj területére 2027-ig négy elkerülő utat (Gyomaendrőd, Mezőberény, Kondoros, Békéscsaba) terveznek, illetve Kondoros és Kunszentmárton között egy fóútvonalat. Ezen útszakaszok, még ha több táji egységre is osztják fel a kistájat, mégis kisebb hatással bírnak a felszabdaltság alakulására, mint a kisebb területü Északkelet Nyírség kistáj területére tervezett hat elkerülő út és M3-as autópálya szakasz (Ór és Vásárosnamény közt) illetve több fơút tervezett szakasza pl. VásárosnamélyTornyosapáca-Komoro-Tuzsér-Tiszabezdéd-Záhony vonalában, több leágazással.

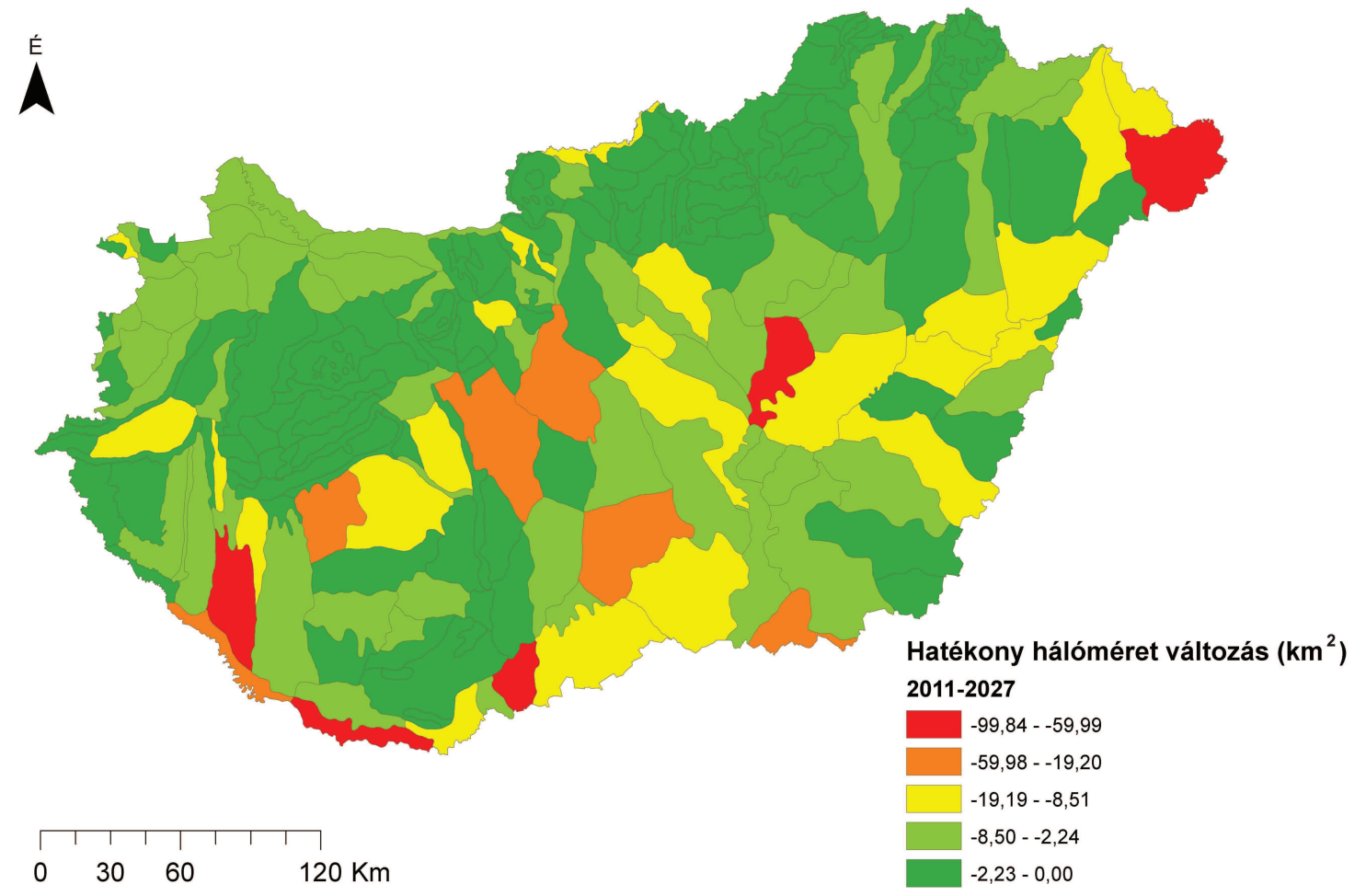

5.17. ábra: A kistájakon belüli Hatékony hálóméret CUT-nek várható változása 2011 és 2027 között (a mesterséges gátak okozta tájfelszabdaltság függvényében)

A nagytávú terv teljes megvalósulása eseten százegy kistáj esetében nem tapasztalhatunk majd „Hatékony hálóméret ${ }_{C U T}$ ” változást. Az élőhelyek ,,hatékonyan” felhasználható területét tekintve a legkedvezőtlenebbé a Dráva-sík kistáj válhat, a 433,27 km²-es összterületéből 2027-re a „Hatékony hálóméret ${ }_{C U T}$ ” majdnem $100 \mathrm{~km}^{2}$-rel lesz kisebb (-99,84 km²). Ennek egyetlen oka, hogy egy főútvonalat terveznek megépíteni Sárvártól délre egészen az országhatárig, így ez a fóútvonal végső szakasza a határmenti kistájat teljes egészében É-D-i irányában kettévágja. Így a táj „Felosztottság Foka” (D): 46,43-ról 70,85-re nő.

Szerencsésnek is mondható, hogy míg a 1990-2011 közötti időszakban $100 \mathrm{~km}^{2}$ feletti „Hatékony hálóméret ${ }_{C U T}$ " csökkentést mérhetünk három kistáj esetében addig a 2027-re, a vizsgálatba bevont adatok alapján ilyen nagyméretü „Hatékony hálóméret ${ }_{C U T}$ ”csökkenést 
nem jelezhetünk elöre. Ennek ellenére nem elhanyagolható tény, hogy $50 \mathrm{~km}^{2}$-es nagyobb hatékony hálóméret csökkenést további négy kistájunk esetében kapunk (5.9. táblázat):

5.9. táblázat: 2011 és 2027 között legnagyobb mértékben felszabdalt öt kistáj tájmetriai mutatóinak eredményei

\begin{tabular}{|l|c|c|c|c|}
\hline Kistáj neve & $\begin{array}{c}\text { NP változás } \\
(\mathbf{d b})\end{array}$ & $\begin{array}{c}\text { S változás } \\
(\mathbf{d b})\end{array}$ & $\begin{array}{c}\text { D változás } \\
\mathbf{( \% )}\end{array}$ & $\begin{array}{c}\text { Mesh Cut változás } \\
\left(\mathbf{k m}^{\mathbf{2}} \mathbf{)}\right.\end{array}$ \\
\hline Dráva-sík & +2 & $+1,56$ & $+24,42$ & $-99,84$ \\
\hline Szolnoki-ártér & +12 & $+5,26$ & $+14,43$ & $-86,23$ \\
\hline Mohácsi -sziget & +3 & $+1,47$ & $+24,45$ & $-85,41$ \\
\hline Nyugat-Belső-Somogy & +9 & $+2,77$ & $+10,01$ & $-75,58$ \\
\hline Szatmári-sík & +7 & $+7,07$ & $+5,81$ & $-59,99$ \\
\hline
\end{tabular}

A jövőt tekintve ezekre a kistájakra tájvédelmi szempontból mindenképp nagyobb hangsúlyt kell fektetni akkor, ha az összes tervezett utat megépítik. A kistájak érzékenységét tekintve azonban a legjobb megoldás az lenne, ha a tervezés során nemcsak a Natura 2000-es területek elhelyezkedését vennék figyelembe (lehetőleg, hogy azokat az építendő utak ne keresztezzék), hanem a dolgozatomban is bemutatott számítások felhasználásával, az élő rendszerek számára a tájak felszabdalódását, mérsékeltebbé tennék. Ehhez azonban további, kistájanként részletesebb tájökológiai vizsgálatok elvégzése szükséges (lsd. később az 5.4.4. A mesterséges gátakkal felszabdalt kistájak érzékenysége, stabilitása fejezetben).

\subsubsection{A mesterséges gátakkal felszabdalt kistájak érzékenysége, stabilitása}

Az előzőekben láthattuk, hogy hogyan változott a táj felszabdaltsága a vizsgált mesterséges gátak figyelembevételével egy múltbéli időszakban (1990-2011) illetve egy országos léptékü terv megvalósulásának estére várható jövőbeli időszakban (2011-2027).

A tájak érzékenységének, stabilitásának vizsgálatához e két időszakot összevonva elemeztem (1990-2027), illetve a tájak, ökológia egységek érzékenységéről és stabilitásáról legtöbb információt szolgáltató mutató, a „Hatékony hálóméret $C U T$ ”változásai alapján négy csoportba osztottam fel a kistájakat (5.10. táblázat, 5.18. ábra). 
1. érzékeny, leginkább veszélyeztetett, instabil tájaink azok a kistájak melyeknek felszabdaltsága mindkét időszakban változott.

2. jövőben potenciálisan érzékeny kistájaink azok a kistájak, melyeknek a felszabdaltsága a múltban nem változott, viszont a jövőbeli úthálózat-bővítés terv alapján mértékben kisebb táji egységekre szabdalódna.

3. jövőben potenciálisan stabilabb állapotba kerülö kistájaink: azok a kistájak, melyeknek a felszabdaltsága változott a múltban, viszont a jövőbeli úthálózat-bővítés terv alapján feltételezhetően nem szabdalódik tovább.

4. stabil, legkisebb mértékben érzékeny kistájaink azok, melyeknek a felszabdaltsága a múltban nem változott és a jövőbeli úthálózat-bővítés terv alapján nem szabdalódna fel kisebb táji egységekre.

5.10. táblázat: A tájak érzékenység - stabilitás csoportjainak megoszlása Magyarországon

\begin{tabular}{|l|c|c|c|c|}
\hline & $\begin{array}{c}\text { 1. érzékeny, } \\
\text { leginkább } \\
\text { veszélyeztetett, } \\
\text { instabil tájaink }\end{array}$ & $\begin{array}{c}\text { 2. jövőben } \\
\text { potenciálisan } \\
\text { érzékeny }\end{array}$ & $\begin{array}{c}\text { 3. jövőben } \\
\text { potenciálisan } \\
\text { stabilabb } \\
\text { állapotba kerül }\end{array}$ & $\begin{array}{c}\text { 4. stabil, } \\
\text { legkisebb } \\
\text { mértékben } \\
\text { érzékeny }\end{array}$ \\
\hline Kistájak száma (db) & 129 & 15 & 46 & 40 \\
\hline Összterület (km) & 67588,8 & 5229,08 & 14381,8 & 5826,31 \\
\hline Összterület (\%) & 72,66 & 5,62 & 15,46 & 6,26 \\
\hline
\end{tabular}

1: Általánosságban elmondható, hogy kistájaink több mint a fele (129, a 230-ból) mindkét vizsgálat időszakban kisebb területi egységre osztódott fel a mesterséges gátak által, ezek a kistájak a leginkább veszélyeztetettek a külső antropogén hatásokra. A viszonylag gyorsan megépített, tájromboló elemek hatására ezekben a kistájakban az élőterek leszűkülnek, a táj egyre érzékenyebbé és instabilabbá válik, hiszen ebbe a csoportba tatozó tájaknál a tájromboló folyamat, az újabb és újabb utak építése még nem fejeződött be, a vizsgálatba adat hiány miatt be nem vont városfejlődés, terjedés nélkül is, (mely még nagyobb mértékben lecsökkentené a természetes élőhelyek nagyságát).

2: Tizenöt kistájunk esetében a múltban nem tapasztalhattunk a vizsgált mesterséges gátak okozta felszabdalódást, viszont, az útvonalhálózat 2027-ig megvalósulható terve alapján ezek a kistájak is érintettek lesznek ezzel a problémával. A „Hatékony hálóméret ${ }_{C U T}$ ” csökkenés várható átlag értéke 3,3 km² , legnagyobb csökkenés értéke 11,7 km² (Hatvani-sík kistájnál). 
3: Negyvenhat kistájunkban várhatóan (optimista oldalról tekintve: további úthálózat bővítést nem terveznének és a települések mérete nem nő) 2027 a táj érzékenysége tovább nem erősödne, a táj képes lehetne egy új, stabilabb állapotba kerülni, hiszen a tervek szerint ezek a kistájak tovább nem szabdalódnának.

4: A tájökológiai felszabdaltság tekintetében a legjobb helyzetben az a negyven kistáj van, mely 1990-től az adatok alapján a 2027-ig nem fog további kisebb táji egységre tagolódni. Természetesen ez a helyzetet is optimista szemszögböl tekintethető, ha további úthálózat bővítést nem terveznének és a települések mérete nem nő. A vizsgált módszerek és adatok alapján, ezen kistájak vannak a legstabilabb állapotban, a legkevésbé érzékenyek.

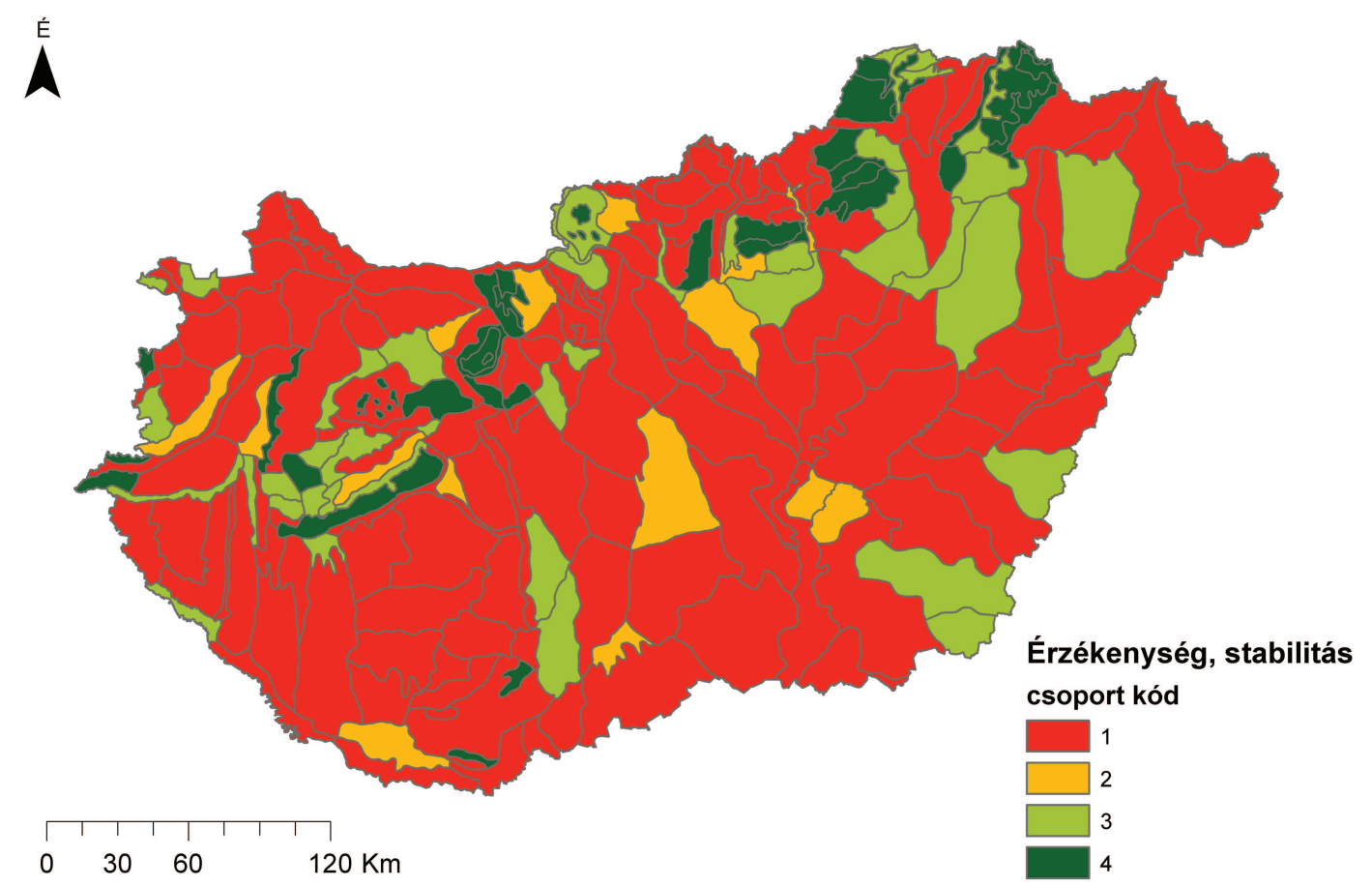

5.18. ába: A kistájak mesterséges gátakkal szembeni érzékenység - stabilitás csoportjai az 1990, 2011, 2027-es adatok felhasználásával

Mint azt korábban is említettem a tájvédelem oldaláról, főként az 1-es és 2-es csoportba tartozó kistájakra kell a leginkább a figyelmet fordítani a gyakorlati tájtervezési, tájrendezési munkák során célszerü elérni, hogy legkevésbé szabdalódjon fel az építendő, terjeszkedő mesterséges gátak által a tájökológiai egység. Az ilyen irányú tájstabilitás romlást csökkenthetné, ha az utak nyomvonalainak tervezése során nemcsak a Natura 2000-es területeket vennék figyelembe, hanem az általam bemutatott tájmetriai paraméterek számolását is elvégeznék. 
A tervezés során az egyes nyomvonal verziók kiválasztásakor a bemutatott tájmetriai számolások alapján kedvezőbben lehetne kialakítani a mesterséges gátak helyét, illetve javaslatokat is lehetne tenni, hogy mely tájak természeti egyensúlyi állapota nem bírna több ilyen létesítmény megépítését (Girvetz et al. 2008., Jaeger et al. 2007, Fu et al. 2010). Ehhez azonban mindenképp további vizsgálatok (Keveiné Bárány 2010), további adatok (pl. felszínborítási térképek- Mucsi et al. 2007, Szilassi - Bata 2012, nemzeti ökológiai hálózat adatai - Tóth 2006), illetve terepi vizsgálati eredmények (pl. élőhely térképezés - Czúcz et al. 2008, ökológiai átjárók használtságának felmérése - Hardy et al. 2004) elvégzése szükségesek.

A 3-as és 4-es csoportba tartozó kistájak esetében a feladat a jelen állapot fenntartása illetve - a lehetőségek szerint - a stabilitás növelése, az érzékenység csökkentése. Ennek egyik eszköze lehet a minél több (megfelelő minőségű) ökológiai átjáró létesítése, zöldfolyosók kialakítása.

A bemutatott példákon keresztül is jól látható, hogy a felszabdaltság változásának vizsgálatakor nem nyújt elegendő információt csupán csak a létesített mesterséges gátak mennyiségének, kiterjedésének összehasonlító vizsgálata (Csorba 2007), illetve a foltszám változás vizsgálata. Célszerübb a „Felosztottság foka” (Division), „Tájfeldarabolódási index” (Landscape Splitting Index) és a „Hatékony hálóméret ${ }_{C U T}$ (Effective Mesh Size ${ }_{\mathrm{CUT}}$ ) változásainak együttes értékelése, melyek más-más mértékegységben fejezik ki a felszabdaltság mértékét, ezáltal több információt nyújtanak a tájak érzékenységéről és stabilitásáról, ha egyszerre elemezzük őket, főként, ha rendelkezésre áll különböző időpontokból származó adat az időbeli változás vizsgálatához.

\subsubsection{A közepes méretarányú tájökológiai egységek határainak érzékenysége}

Az előzőekben bemutatott tájfelszabdaltságra vonatkozó eredmények minden esetben a vizsgálati egységekre vonatkoztatottak, vagyis csak a kistájak határain belüli értelmezett felszabdaltságot mutatják. Objektíven, de hasonlóan tájmetriai paraméterek kiszámításával szeretettem volna jellemezni mesterséges gátak okozta tájfelszabdaltságot is. Ennek érdekében célszerübb volt a hatékony hálóméret kiszámításának határon átnyúló kapcsolódási módszerét (cross boundary connection - Mesh ${ }_{\mathrm{CBC}}$ ) is alkalmaznom:

Vizsgálataim során összehasonlítottam (5.11. táblázat), a „Hatékony hálóméret ${ }_{C U T}$ "és a „Hatékony hálóméret ${ }_{C B C}$ ” értékek eredményeit az 1990-es, 2011-es és 2027-re előrejelezhető 
állapotra (a CBC módszer eredményének és a CUT módszer eredményének különbségképzésével).

5.11. táblázat: Hatékony hálóméret ${ }_{C U T}$ és a Hatékony hálóméret ${ }_{C B C}$ módszer közti eredmények különbségei 1990-es, 2011-es és 2027-es állapotokban

\begin{tabular}{|l|c|c|c|}
\hline & $\mathbf{1 9 9 0}$ & $\mathbf{2 0 1 1}$ & $\mathbf{2 0 2 7}$ \\
\hline Érintett kistájak száma (db) & 9 & 17 & 33 \\
\hline Legnagyobb különbség (ha) & $+19,26$ & $+28,03$ & $+19,26$ \\
\hline Átlagos különbség (ha) & $+3,15$ & $+3,75$ & $+1,60$ \\
\hline Legkisebb különbség (ha) & $+0,0001$ & $+0,0001$ & $+0,0001$ \\
\hline
\end{tabular}

Az 1990-es állapotot tekintve a két eltérő módszerrel számított Hatékony hálóméret értékek között kilenc kistáj esetében kaptam különbséget. Viszont e kilencből csupán egynél tapasztaltam, hogy a határon átnyúló kapcsolódással számoló „Hatékony hálóméret ${ }_{C B C}$ ” értéke 1 hektárral nagyobb, mint a „Hatékony hálóméret ${ }_{C U T}$.. Ez a kistáj a Vilonyai-hegyek $(+19,26$ ha $)$.

2011-ben a két módszer közti különbség tizenhét kistájban jelenik meg. A különbség legnagyobb értéke ugyancsak a Vilonyai-hegyek (+28,03 ha) kistáj esetében látható, illetve 1 hektárnál nagyobb különbséget további öt kistáj esetében kaptam (Nyugati-Mátraalja, Mátralába, Veszprém-Nagyvázsonyi-medence, Nézsa-Csővári-dombság, Kosdi-dombság).

2027-re jelzett állapotra számolt különbség a két módszerben már 33 kistájban adódott. Ugyancsak a Vilonyai - hegyek kistájban (+19,26 ha) a legnagyobb a különbség, és a 2011-es állapottal megegyező eredményt kaptam az 1 hektár feletti különbségek megjelenését illetően.

Ezen eredmények az mutatják, hogy Magyarország vasút- és úthálózata olyan sürü, hogy az általuk felszabdalt táji egységek határai döntő többségben megegyeznek a vizsgált kistájak határaival. Ez alól kivételt képeznek a fent említett kistájak, ahol a két módszer közötti különbség nem elhanyagolható, az élőhelyek területét illetve az területükön élő élőlények mozgási lehetőségeit tekintve. Hiszen pl. a Vilonyai-hegyek kistáj területén az élőlények által „hatékonyan felhasználható” háló mérete nagyobb, annak határa nem esik egybe a kistáj határával, az élőlény át tud lépni a kistáj határán, hiszen a kistájaink határa valójában nem jelent számára gátat, fizikailag nem megfogható (Mezősi-Bata 2011/a).

Minél több mesterséges gátat vonunk be a vizsgálatba, annál nagyobb lesz a felszabdaltság, ezáltal a hatékony hálóméret nagysága csökkenést mutat. Természetesen - a vizsgált három felszabdaló tényezőn kívül - a mesterséges gátak száma bővíthető, de vizsgálataimba csak e 
gyors megépítési sebességgel rendelkező, legnagyobb tájromboló erővel és hatással bíró mesterséges gátakat vizsgáltam. A bemutatott módszerek lehetővé tennék akár a természetes gátak vizsgálatát is, azonban a tájak érzékenységére nagyobb hatással vannak a mesterséges elemek, gátak megjelenése. Azok építése a táj természetes fejlődését tekintve hirtelen következnek be és nagyobb „romboló” erővel bírnak, mint a természetes gátak a mesterségesekhez képest „lassú” megjelenései a tájban. 


\section{6. Összegzés}

A táj a természetföldrajz leggyakrabban használt fogalma, kutatási területegysége. A tájat a saját nézőpontjából nagyon sok, a fogalmat alkalmazó tudományág használja. A táj földrajzi megközelítése leginkább természeti földrajzi tartalmú („természettörténeti” kategória Marosi 1980), amely értelmezés szerint itt egy felszíndarab az itt ható folyamatok szerkezete és a müködése alapján alkot egyedi, komplex egységet (Pécsi et al. 1972, Mezősi 2003).

A tudományos igényü magyarázatok is leginkább ezt a szemléletet követik napjainkban. Így a földrajzban ma úgy tekintjük a tájakat, hogy azok kereteit, alapjait a természeti tényezők határozzák meg. Pontosabban a (természeti) tájalkotó tényezők együttesen, kiegészülve a társadalmi tevékenység jellemző entitásaival, a mesterséges elemekkel kölcsönhatásban alkotnak lehatárolható jellegzetes értékekkel rendelkező egységeket. Ebben a megközelítésben a természeti tényezők elsődleges szerepűek és a többi tájalkotó tényező e kapcsolatrendszert módosító szerepe fejeződik ki. Így érthető, hogy emiatt a természeti tényezők alapján olykor nehezen lehatárolható néprajzi, történelmi kategóriák használatától gyakran eltekintettek.

A területek, egységek, lehatárolása általános probléma a földtudományokban, különösen, ha komplex módon elemezzük a természeti rendszereket (Mezősi et al. 2013) vagy társadalmi-ökológiai rendszereket (Blanka et al. 2012, Mezősi et al. 2012). Az adminisztratív egységeket illetve azok határait leggyakrabban statisztikai, regionális vagy országos léptékü elemzésekhez használják, ezen adminisztratív egységek határait politikusok határozták meg és a történelem során gyakran megváltoztatták. A területi- és tájtervezési munkákhoz a tájtervezők jól meghatározott, pontos határokat szeretnének használni.

A tájökológiában két fő tudományos megközelítés létezik a lehatárolás problémájának megoldására (Bata et al. 2013):

(1) a tradicionális módszerben a tájalkotó tényezők szubjektív integrálásával végzik el az egységek lehatárolását (szubjektív szegmentáció) vagy (2) a szegmentáció megoldásánál a lehatárolást matematikai, geostatisztikai módszerekkel, illetve digitális földrajzi adatok alkalmazásával alakítják ki (objektív szegmentáció).

(1) A tradicionális módszerben a tájalkotó tényezők felhasználásával hozzák létre a tájak felosztásának hierarchikus szintjeit: a nagytájak, középtájak és kistájak egységeit. A legtöbb tájfelosztást Európában ilyen módszerekkel és hierarchiaszintekkel készítették el. 
A különböző területekre (síkvidék, dombvidék, hegyvidék) a kulcsparaméterek (tájalkotó tényezők) kiválasztása és az alkalmazott integrálása okozta a legfőbb problémát. A tájalkotó tényezők súlyozása mellett empirikus ismereteket is felhasználtak a lehatároláshoz (Haase 1976, Marks 1979), az alapadatok felhasználása teljes egészében nem ismert, így ezen tradicionális módszer határozottan nem biztosítja a megismételhetőséget. Statisztikai szemszögből tekintve a tradicionális módon definiált tájak további gyengesége, hogy a felhasznált tényezők adataikat tekintve nominálisak, ezért ellenőrzés során a rajtuk végrehajtható statisztikai elemzések köre erősen korlátozott. Az első ilyen módszerrel kialakított lehatárolást Magyarországon közel 100 évvel ezelőtt a geomorfológiai adatok alapján készültek. Később a táj lehatárolásokhoz további geoökológiai tényezőket integráltak (Pécsi - Somogyi 1967, Neef 1967, Haase 1976, 1991).

A Magyarországon ismert tájfelosztás (Pécsi - Somogyi 1967) is ilyen módon (szubjektív szegmentációval) készült. A felosztás egységeinek részletes jellemzését a Magyarország kistájainak kataszterének első (Marosi-Somogyi szerk. 1990) illetve átdolgozott, kibővített második kiadásában (Dövényi szerk. 2010) találhatjuk meg.

Az alkalmazott szubjektív módszer viszont nem adja meg a lehetőséget számunkra, hogy a megfelelő adatok birtokában a felosztás ugyanolyan eredményre jutóan megismételhető legyen. Néhány - hagyományos módon készített - lehatárolási problémát már az 1980-as években megvitattak (Mosimann 1984, Forman - Godron 1986, Leser 1997). A magyar tájfelosztás lehatárolási problémái, illetve javaslatok az egyes kistájak, középtájak határainak módosítására főként az utóbbi évtizedben jelentek meg (pl. Csapó 2008, Szilágyi 2009, Lóki Szabó 2006, Pénzes 2009, Benedek 1996, Flórián 2008, Ladányi 2010, Deák 2010).

(2) A képszegmentációs módszerekkel, mint pl. a többváltozós szegmentációval (multiresolution segmentation) számos térbeli tényező együttes kezelése, integrálása megoldhatóvá válik. A képszegmentációs módszereket az 1970-es években dolgozták ki (Haralick 1973, Haralick - Shapiro 1985). Kezdetben ezeket a szegmentációs eljárásokat főként a távérzékelt (spektrális) adatok szegmentálására és osztályozására használták (Burnett - Blaschke 2003, Haralick - Shapiro 1985, Ryherd - Woodcock 1996, Baatz - Schäpe 2000, Bock et al. 2005, Boutin et al. 2008, Lucas et al. 2011), de a módszer alkalmazható vektoros adatok felhasználásával is (Mücher et al. 2010, Renetzeder et al. 2010).

Az elmúlt évtizedben a föltudományok különböző területein több új szegmentációs algoritmust és azok alkalmazásait tesztelték, de a pixel alapú elemzéseket gyakran kritizálták, Blaschke - Strobl (2001), Burnett - Blaschke (2003) részletesen kifejtette ezek hibáit. Az objektum alapú képi elemzések (OBIA) megfelelő módon alkalmazhatóak a táji 
elemzésekben is, ezek a pixelosztályozás mellett figyelembe veszik a szegmentált egységek, objektumok nagyságát, formáját és helyzetét is (Blaschke - Strobl 2001, Drăgut - Blashke 2006).

Számos tanulmány jelent meg, mely alátámasztja, hogy a többváltozós szegmentáció alkalmas módszere lehet az objektíven a térbeli egységek lehatárolásához. A módszertana alapján a lehatárolás bármikor újra elkészíthető, megismételhető (Blaschke - Strobl 2001, Mücher et al. 2010).

A szubjektív szegmentáció gyengeségeit figyelembe véve Magyarország területére egy új, objektív tájlehatárolást készítését tüztem ki célként, mely matematikai-statisztikai eszközökkel kezeli a fent említett problémákat. Annak érdekében, hogy megismételhető és objektív szegmentációval készült tájlehatárolást készítsek, - elkerülve a tényezők súlyozását illetve a szubjektív elemeket - munkám során a többváltozós szegmentáció módszerét alkalmaztam, mely kezeli a különböző tájalkotó tényezők integrációjának kérdését is.

A többváltozós szegmentációt már korábban is használták hasonló célokra, például kis méretarányban a European Landscape Character Assessment Initiative (ELCAI 2005) az Európai Tájtípus Térkép (LANMAP) elkészítéséhez. Célom volt ezen módszer alkalmazásának továbbfejlesztése közepes méretarányban, jobb térbeli felbontás mellett, több tájalkotó tényező bevonásával.

A szegmentáció folyamatában föként természeti tájalkotó tényezők közel egyenlő számú kategóriáit használtam fel, kivételt képez ez alól az antropogén hatás integrálása miatt a hemeróbiaszint 6 kategóriája. Ezen kívül a vizsgálatba más társadalomtudományi, entrográfiai és kultúrtudományi tényezőket nem vizsgáltam, habár más alkalmazásokban pl. a területi tervezéskor ezek vizsgálata, figyelembe vétele is elengedhetetlen.

A szegmentáció eredményéül kapott táji egységek formájukat és ökológiai paramétereiket tekintve hasonlóak a tradicionálisan definiált kistájak tulajdonságaihoz (Foltok száma, Átlagos foltméret, Fraktáldimenzió átlaga és a Magterületi index).

A módszer egyik nagy előnye, hogy objektivitása és az alkalmazott matematikaistatisztikai módszerek révén az eredmény magasabb homogenitást mutat, jobban illeszkednek az így létrehozott táji egységek határai a felhasznált természeti tényezők határaihoz. Az alkalmazott módszer másik előnye, hogy a szegmentált táji egységek részletesebbek, jobb felbontásúak, mint a LANMAP esetén (Mücher et al. 2010), másrészt az alkalmazott többváltozós szegmentáció több tényezőt, jobb térbeli felbontásban vesz egyszerre figyelembe. 
Jelen esetben a „klasszikus” szegmentáció validálást nem lehet készíteni a szegmentált táji egységekre, mert nincs egy általánosan elfogadott felosztás, melyhez a validációt el lehetne végezni. Így a szegmentált táji egységeket több lépésben összehasonlító elemzésekben „validáltam”. A komplex összehasonlítások eredményei azt mutatták, hogy a szegmentált táji egységek határa legnagyobb átfedéssel a Vegetációs alapú tájbeosztás határaival egyezik meg, 66,33 százalékban.

A komplex összehasonlító vizsgálatok együttesen alátámasztják, hogy a többváltozós szegmentáció alkalmas módszer lehet egy új tájfelosztáshoz. Ugyanakkor az eredményül kapott szegmentált táji egységek meghatározásához elkerülhetővé vált a sokszor igen költséges terepi megfigyelések, mintavételezések elvégzése, természetesen a terepi mintavételezés csak abban az esetben hagyható el, ha megfelelően jó minőségü térbeli adatok állnak rendelkezésünkre a többváltozós szegmentáció lefuttatására. Ugyanezen módszerrel készített LANMAP egységeihez hasonlítva a szegmentált táji egységekhez több tájalkotó tényezőt, nagyobb térbeli felbontásban használtam

A regionális összehasonlító elemzések azt mutatták, hogy az objektív többváltozós szegmentáció jól alkalmazható a közepes méretarányú tájökológiai egységek lehatárolásához. Az elemzések arra is rávilágítottak, hogy a szegmentált táji egységek egy új tájfelosztásként elfogadhatóak (Bata et al. 2013).

A másik megközelítés szerint ezzel szemben a tájak, természeti tényezők határai ritkán jól megkülönböztethetőek, elhatárolhatóak (Csorba 2008, Mezősi-Bata 2011/a). Ezért a tájökológia alapú vizsgálatokban a tájak integrált egységek, viszont határaik ökotonként kezelendőek. A határok nem vonalas objektumként történő kezelése a (bővíthető számú és típusú) tájalkotó tényező határának fuzzy logika szerinti elemzésén alapulhat (Ji 2002, Arnot Fisher 2007, Chong et al. 2010, Mezősi - Bata 2011/a).

A megoldás biztosítja, hogy a vizsgálatok során a tájalkotó paraméterek azonos típusúak legyenek (ugyanis gyakori, hogy nagyon változatos típusokkal végezzük a statisztikai elemzéseket, noha a nominális vagy a skaláris típusok csak nagyon eltérő lehetőségeket biztosítanak), de kikerülnek az értékelésből a tényezők súlyozásának sok hibát rejtő lépései is. Ezzel együtt is fontos a tudatos paraméterválasztás és szükség szerint a fuzzy technika kombinálható a mintázat előzetes statisztikai vizsgálatával, mint ahogy azt például McGarigal - Marks (1995) és Herzog et al. (2001) bemutatta.

A fuzzy logikával történő tájhatár elemzés elsősorban nem a tájhatárok módosítását szolgálja, hanem azok más szemléletủ értelmezését mutatja be, ahol a hangsúly a gyakran a határok sávszerü megjelenésében van. Ez összecseng azzal a tapasztalatunkkal, hogy a 
határok mozgásban vannak (erről adatokkal, a vegetációval kapcsolatban rendelkezünk - pl. Méri - Körmöczi 2010), ami a magterületek viszonylagos állandóságát és az ökotonoknak az alkotó típusoktól függő pulzálását mutatják, azaz nem merev kategóriák. Elemzéseim azt mutatják, hogy a tájhatárok általában néhány 100 m és néhány km szélesség átmeneti zónát reprezentálnak (Mezősi - Bata 2011/a).

Ez a problémakör a tájak stabilitását, változásuk érzékenységét érinti már. Az ugyanis ismert, hogy a táj rendszernek tekinthető, ahol az antropogén hatás (de általában egy tájalkotó elem) változása kiválhatja rendszer instabilitását és változást indukál. A táj érzékenységét is zavaró hatásokra adott gyors válaszadásként értelmezik, amely a táji rendszer feltételes instabilitását jelzi.

Vizsgálataimban a táji rendszer, -egységek érzékenységének, stabilitásának meghatározásához a mesterséges gátak okozta tájbelszabdaltság térbeli és időbeli változását elemeztem. A mesterséges gátak, mint pl. az utak, vasutak vagy a települések a táj egységét nagymértékben képesek megbontani. Az utak és a vasutak kettévágják az addig egybefüggő tájfoltokat, ezzel alapvetően módosítva azok ökológiai tulajdonságait (Forman - Alexander 1995, Trombulak - Frisell 2000, Forman et al. 2003). A fragmentáció következtében a táj feldarabolt részeiben az ökológiai stabilitás romlik, a természetes anyag- és energiaáramlási folyamatok megváltozhatnak (Csorba 2005, Moser et al. 2007). Minél több mesterséges gát jelenik meg a tájban az annál felszabdaltabb lesz, az addig egybefüggő folt a két vagy több részre tagolódik, a tájban addig fennálló stabilitás megváltozik. A mesterséges gátak okozta felszabdaltság mérésére a különböző tájmetriai mérőszámok, a „Foltok száma”, „Felosztottság foka”, „Tájfeldarabolódási index” és a „Hatékony hálóméret” (kétféle számítási módszer) együttes elemzése a legmegfelelőbb.

Az 1990-es és 2011-es tájfelszabdaltsági állapotok összehasonlításával képet kaptam a tájak érzékenységének változásáról, a 2027-es gyorsforgalmi - és főúthálózat nagytávú terv vizsgálatba történő bevonásával, pedig egy várható, előrejelezhető állapotról is.

A tradicionálisan definiált kistájak tekintetében a Hatékony hálóméret 1990-2011 és 20112027 értékvátozásai alapján kialakított négy érzékenységi, stabilitási csoport jól reprezentálja, hogy mely tájaknál várható (1) érzékenység növekedés, folyamatos stabilitásromlás az újabb és újabb mesterséges gátak létesítésével, terjedésével az élőhelyek életterének csökkenése szempontjából. Vannak olyan tájak (2), melyek csak a jövőt tekintve lehetnek érzékenyek, illetve olyanok (3), melyek a jövőt tekintve stabilabb állapotba kerülhetnek. Illetve a 4. csoportba kerülő tájak a múltat és a jövőt tekintve nem voltak/lesznek érintettek a vizsgálatban figyelembe vett mesterséges gátak okozta tájfeldarabolódásban. 
Az alkalmazott módszer előnye, hogy az egyes nyomvonal verziók kiválasztásakor a tájmetriai mutatók segítségével kedvezőbben lehetne kialakítani a mesterséges gátak helyét, illetve javaslatokat is lehetne tenni, hogy mely tájak természeti egyensúlyi állapota nem bírna több ilyen létesítmény megépítését (Girvetz et al. 2008, Jaeger et al. 2007, Fu et al. 2010). Ehhez azonban mindenképp további vizsgálatok (Keveiné Bárány 2010), további adatok (pl. felszínborítási térképek - Mucsi et al. 2007, Szilassi - Bata 2012, nemzeti ökológiai hálózat adatai - Tóth 2006), illetve terepi vizsgálati eredmények (pl. élőhely térképezés - Czúcz et al. 2008, ökológai átjárók használtságának felmérése-Hardy et al. 2004) szükségesek. 


\section{Köszönetnyilvánítás}

Mindenekelőtt hálás köszönetemet szeretném kifejezni témavezetőmnek, Prof. Dr. Mezősi Gábor egyetemi tanárnak sokéves útmutatásáért, bizalmáért, tanácsaiért és segítségéért, mely nélkül dolgozatomat sem készíthettem volna el.

Köszönettel tartozom Dr. habil. Szilassi Péter föiskolai docensnek, Dr. Boudewijn van Leeuwen egyetemi tanársegédnek és Dr. habil. Burghard C. Meyer kollégának a dolgozat írása során nyújtott szakmai tanácsokért, ötletekért, segítésért és bátorításért.

Külön köszönettel tartozom a Ribár András térinformatikusnak, a Térkép Kft.-nek, hogy a 1:100 000-es léptéknek megfelelő felbontású, település szintű országtérképének térinformatikai állományának kutatási célú használatát engedélyezték. Köszönetemet szeretném kifejezni Dr. Ladányi Zsuzsannának és Dr. Deák József Áronnak is, hogy rendelkezésre bocsátották saját kutató munkájuk eredményeit, az egyes kistájak módosított határainak állományát.

Köszönettel tartozom a Természeti Földrajzi és Geoinformatikai Tanszék dolgozóinak, volt és jelen PhD hallgatóinak, hogy munkámat támogatták. Külön köszönöm Katona Orsolyának, akitől oly sok baráti segítségét kaptam az ábrák kritikus szemléletű átnézésekor is. Köszönöm Kovács Katalinnak a fordításban nyújtott segítségét.

Végül, de nem utolsó sorban, köszönöm Családtagjaimnak és Páromnak a támogatásuk során nyújtott sok-sok szeretetet, megértést és türelmet, mely nélkül dolgozatomat sem készíthettem volna el. 


\section{Irodalomjegyzék}

Arnot C. - Fisher P. 2007: Mapping the ecotone with fuzzy sets. In: Morris A. - Kokhan S. (eds.) NATO Science for Peace and Security, Series C: Environmental Security. Springer, Berlin, 19-32.

Baatz M. - Schäpe A. 2000: Multiresolution segmentation - an optimization approach for high quality multi-scale image segmentation. In: Strobl J. - Blaschke T. - Griesebner G. (eds.) Angewandte Geographische Informationsverarbeitung. XII, Wichmann-Verlag, Heidelberg, 12-23.

Barta K. - Szatmári J. 2010: Antropogén hatások a belvíz-képződésben. Esettanulmány az M5 autópálya szatymazi szakaszának talajvízáramlásban betöltött szerepéről. Hidrológiai Közlöny 90/2., 23-25.

Barta K. - Szatmári J. - Posta Á. 2011: A belvízképzıdés és az autópályák kapcsolata. Földrajzi Közlemények 135/4., 379-387.

Barta K. - Farsang A. - Puskás I. 2012: Tájhatárok talajtani vonatkozásai: ökotonok talajváltozatai a Duna-Tisza-közi hátság és a Dél-Tisza-völgy határán. In: Farsang A. Mucsi L. - Keveiné Bárány I. (szerk.) Táj - érték, lépték, változás. Geolitera, Szeged, 97-105.

Bastian O. 1997: Gedanken zur Bewertung von Landschaftsfunktionen - unter besonderer Berucksichtigung der Habitatfunktion. - NNA-Berichte 97/3., 106-125.

Bastian O. - Schreiber K. F. (eds.) 1994: Analyse und okologische Bewertung der Landschaft. - Spektrum Akademischer Verlag, Heidelberg-Berlin, 564.

Bata T. - Mezősi G. - Meyer B. C. 2013: Landscape units in Hungary using multiresolution segmentation of geo-data and fuzzy analysis. Landscape and Urban Planning (megjelenés alatt)

Benedek Z. 1996: Érmellék. A hónap könyvei, Helios Kiadó, Orosháza.

Blanka V. - Mezősi G. - Loibl W. - Szépszó G. - Csorba P.- Meyer B. - Bata T. - Nagy R. - Vass R. 2012: Meso-region scale change of climate in the 21th century and its potential impacts on the environment in the Carpathian Basin. Review of climate change research program at the University of Szeged (2010-2012), 25-40.

Blaschke T. - Strobl J. 2001: What's wrong with pixels? Some recent developments interfacing remote sensing and GIS. GIS-Zeitschrift für Geoinformationssysteme 6., $12-17$.

Blume P. - Sukopp H. 1976: Ökologische Bedeutung anthropogener Bodenveränderungen. Schriftenreihe Vegetationskunde 10., 7-89. 
Bock M. - Rossner G. - Wissen M. - Remm K. - Langanke T. - Lang S. - Klug H. -

Blaschke T. - Vrščaj B. 2005: Spatial indicators for nature conservation from European to local scale. Ecological Indicators 5., 322-338.

Bokor P. 1989: Vas megye természetföldrajzi tájbeosztása. Vasi Szemle 43/1., 26-47.

Bokor P. 1996: A Nyugat-magyarországi peremvidék és környezetének új természeti tájfelosztása. - BDTF Tud. Közl. X. Természettudományok 5., 169-181.

Bokor P. 2007: Vas megye tájfelosztása - Vas megye természetföldrajza. Kézirat.

Borgulya I. 1998: Neurális hálók és fuzzy-rendszerek. Dialóg Campus Kiadó, Budapest Pécs, 226.

Boutin C. - Baril A. - Marti, P.A. 2008: Plant diversity in crop fields and woody hedgerows of organic and conventional farms in contrastinglandscapes. Agriculture, Ecosystems and Environment 123., 185-193.

Bulla B. 1964: Magyarország természeti földrajza. Tankönyvkiadó, Budapest, 364-390.

Bulla B. - Mendöl T. 1947: A Kárpát-medence földrajza. Egyetemi Nyomda, Budapest, 611.

Burnett C. - Blaschke T. 2003: A multi-scale segmentation/object relationship modelling methodology for landscape analysis. Ecological Modelling 168., 233-249.

Cholnoky J. 1929: Magyarország földrajza. Danubia Könyvkiadó, Budapest, 176.

Chong C. - Manchun L. - Qiuhao H. - Zhenjie C. - Kun M. 2010: Mapping land cover types as fuzzy sets. 18th International Conference on Geoinformatics, 1-6.

Clinton N. - Holt A. - Scarborough J. - Yan L. - Gong P. 2010: Accuracy Assessment Measures for Object-based Image Segmentation Goodness. Photogrammetric Engineering \& Remote Sensing 76., 289-299.

Czúcz B. - Molnár Zs. - Horváth F. - Botta-Dukát Z. 2008: The natural capacity index of Hungary. Acta Botanica Hungarica 50., 161-177.

Csapó O. 2008: Az Örség térbeli elhatárolás problémái. Földrajzi Értesítő 58/3-4., 313-333

Csima P. 2009: Tematikus tájváltozás-elemzések - a települési táj. http://www.geo.uszeged.hu/web/sites/default/files/15Konferenciak/absztraktkotet.pdf 18 p. (Megtekintve: 2013.02.04.)

Csima P. - Gergely A. - Kiss G. - Módosné Bugyi I. 2004: Természetvédelem, védett területek tervezése. - Egyetemi jegyzet. BKAE, Budapest, 214.

Csorba P. 1997: Tájökológia. Kossuth Egyetemi Kiadó, Debrecen, 113.

Csorba P. 2005: Hazai tájak ökológiai szempontú szerkezetének vizsgálata http://geography.hu/mfk2006/pdf/Csorba\%20P\%E9ter.pdf (Megtekintve: 2013.02.04.)

Csorba P. 2007: Tájszerkezet kutatások, tájmetriai mérések Magyarországon. MTA Doktori értekezés Debrecen, 131. 
Csorba P. 2008: A tájhatárok kijelölése és változása. Földrajzi Közlemények 132/2., $220-226$.

Csorba P. - Szabó Sz. 2009: Degree of human transformation of landscapes: a case study from Hungary. Hungarian Geographical Bulletin 58., 91-99.

Deák J.Á. 2008: Csongrád megye kistájainak élőhelymintázata és lehatárolása. - IV. Magyar Földrajzi Konferencia. Debrecen.

http://geography.hu/mfk2006/pdf/De\%E1k\%20J\%F3zsef\%20\%C1ron.pdf(Megtekintve: 2013.02.04.)

Deák J.Á. 2010: Csongrád megye kistájainak élőhely-mintázata és tájökológiai szempontú értékelése. Ph.D. disszertáció, Szegedi Tudományegyetem, Éghajlattani és Tájföldrajzi Tanszék, Szeged

Dövényi Z. (szerk.) 2010: Magyarország kistájainak katasztere. - MTA FKI, Budapest, 876.

Drăgut L. - Blaschke T. 2006: Automated classification of landform elements using objectbased image analysis. Geomorphology 81., 330-344.

ELCAI 2005: Wascher D.M. (eds.) European Landscape Character Areas - Typologies, Cartography and Indicators for the Assessment of Sustainable Landscapes. Final Project Report as deliverable from the EU's Accompanying Measure project European Landscape Character Assessment Initiative (ELCAI), funded under the 5th Framework Programme on Energy, Environment and Sustainable Development (4.2.2), 160.

European Environment Agency 2000: CORINE Land Cover Technical Guide-Addendum 2000. EEA, Copenhagen.

Fi I. - Bocz P. - Pethő L. - Tóth Cs. 2012: Útburkolatok méretezése. TERC Kft, 458.

Flórián T. 2008: Az Érmellék természeti földrajzának néhány vonása. In: Ekéné Zamárdi Ilona (szerk.) Természeti környezet, a mezőgazdaság lehetőségei. Érmelléki kalauz 2. Debrecen, 53-68.

Forman R.T.T. 1995: Landscape mosaics. Land Mosaics: -The Ecology of Landscapes and Regions. Cambridge University Press, Cambridge/New York, 632.

Forman R.T.T. - Godron M. 1986: Landscape Ecology. John Wiley and Sons, Inc., New York, NY, USA.

Forman R.T.T. - Alexander L.E. 1995: Roads and Their Major Ecological Effects. Annual Review of Ecology and Systematics 29., 207-231.

Forman R.T.T. - Sperling D. - Bissonette J.A. - Clevenger A.P. - Cutshall C.D. - Dale V.H. - Fahrig L. - France R. - Goldman C.R. - Heanue K. - Jones J.A. - Swanson F.J.Turrentine T. - Winter T.C. 2003: Road ecology: science and solutions. Island Press, Washington, D.C., USA, 504. 
Fu W. - Liu S. - Degloria SD. - Dong S. - Beazley R. 2010: Characterization the "fragmentation-barrier" effect of road networks on landscape connectivity: A case study in Xishuangbanna, Southwest China. Landscape and Urban Planning 95., 122-129.

Gilpin M.E. - Soulé M.E. 1986: Minimum viable populations processes of species extinction. In: Soulé M.E. (eds.) Conservation Biology. The science of scarcity and diversity. Sinauer Assoc. Inc. Sunderland, 19-34.

Girvetz E.H. - Thorne T.H. - Berry A.M. - Jaeger J.A.G. 2008: Integration of landscape fragmentation analysis into regional planning: A statewide multi-scale case study from California, USA. Landscape and Urban Planning 86., 205-218

Góczán L. 1961: Vita Magyarország természeti földrajzi tájbeosztásáról. Földrajzi Közlemények 40., 258-264.

Haase G. 1976: Die Arealstruktur chorischer Naturräme. Petermanns Geographische Mitteilungen 2, 130-135.

Haase G. 1991: Approaches and methods of landscape diagnosis. Ekologia CSFR, 9., 31-44.

Haines - Young R. - Chopping M. 1996: Quantifying landscape structure: A review of landscape indices and their aplicatioton to forested landscapes, Progress in Physical Geography 20., 418-445.

Hajdú-Moharos J. - Hevesi A. - Horváth Zs. 2000: A Kárpát-Pannon térség természeti tájbeosztása. In: Karátson D. (szerk.): Magyarország földje. (Pannon Enciklopédia) Kaloprint Kiadó, Kalocsa., 274-285.

Haralick R.M. - Shanmugan K. - Dinstein I. 1973: Textural features for image classification. IEEE Transactions on Systems, Man and Cybernetics 3/6., 610-621.

Haralick R.M. - Shapiro L. 1985: Survey: image segmentation techniques. Computer Vision Graphics and Image Processing 29., 100-132.

Hardy A. - Clevenger A.P. - Huijser M. - Neale G. 2004: An overview of methods and approaches for evaluating the effectiveness of wildlife crossing structures: emphasizing the science in applied science. In: Irwin C.L.- Garrett P. - McDermott K.P. (eds.) Proceedings of the 2003 International Conference on Ecology and Transportation, Center for Transportation and the Environment, North Carolina State University, Raleigh, 319-330.

Hargis C.D. - Bissonette J.A. - David J.L. 1998: The behavior of landscape metrics commonly used in the study of habitat fragmentation. Landscape Ecology 13., 167-186

Harris L.D. 1984: The Fragmented Forest: Island Biogeography Theory and the Preservation of Biotic Diversity. University of Chicago Press, Chicago, 230. 
Hegedűs A. 2006: Segithet-e a domborzatmodell a kistájak elhatárolásában, a tájbeosztásban? HunDEM, Miskolc, 11 p. www.uni-miskolc.hu/ fkt/HunDEM2006/Cikkek/HegedusA.pdf (Megtekintve: 2013.02.04.)

Herzog F. - Lausch A. - Müller E. - Thulke H.H. -Steinhardt U. - Lehmann S. 2001: Landscape Metrics for Assessment of Landscape Destruction and Rehabilitation. Environmental Management 27., 91-107.

Isachenco A.G. 1953: Main questions of physical geography. Len. Univ. Publisher. (in Russian)

Jaeger J.A.G. 2000: Landscape division, splitting index, and effective mesh size: New measures of landscape fragmentation. Landscape Ecology 15/2., 115-130.

Jaeger J.A.G. 2002: Landscape fragmentation. A transdisciplinary study according to the concept of environmental threat (in German, Landschaftszerschneidung. Eine transdisziplinäre Studie gemäß dem Konzept der Umweltgefährdung). Verlag Eugen Ulmer, Stuttgart, 447.

Jaeger J.A.G. - Schwarz-von Raumer H.G. - Esswein H. - Müller M. - SchmidtLüttmann M. 2007: Time series of landscape fragmentation caused by transportation infrastructure and urban development: a case study from Baden-Württemberg (Germany). Ecology and Society 12/1., 22.

James P.E. - Jones C.F. - Wright J.K. (eds.) 1954: American Geography: Inventory and Prospect. Syracuse University Press, Syracuse.

Jenks G.F. 1967: The data model concept in statistical mapping. In: Konrad F. (eds.) International Yearbook of Cartography 7., 187.

Ji M. 2002: Fuzzy modelling of African ecoregions and ecotones using AVHRR NDVI temporal imagery. Geocarto International 17., 23-32.

Johansen K. - Arroyo L.A. - Armston J. - Phinn S. - Witte C. 2010: Mapping riparian condition indicators in a sub-tropical savanna environment from discrete return LiDAR data using object-based image analysis. Ecological Indicators 10., 796-807.

Jongman R. 1995: Nature conservation planning inEurope: developing ecological networks. Landscape and Urban Planning 32., 169-183.

Kádár L. 1941: A magyar nép tájszemlélete és Magyarország tájnevei. Országos Táj- és Népkutató Intézet, Budapest, 24.

Kerényi A. 2007: Tájvédelem. Pedellus Tankönyvkiadó, Debrecen, 184.

Keveiné Bárány I. 2010: Gondolatok a Közép-európai tájökológiai kutatásokról. In: Szilassi P. - Henits L. (szerk.) Földrajzi Tanulmanyok 5, Tájváltozás értékelési módszerei a XXI. Században, 135-142. 
Kóczy T. L. - Tikk D. 2000: Fuzzy rendszerek. TypoTEX, Budapest, 209.

Kogutowicz K. 1930, 1936: Dunántúl és Kisalföld írásban és képekben I-II. - Magyar Királyi Ferenc József Tudományegyetem Földrajzi Intézete, Szeged, 298 és 253.

Kowarik I. 1988: Zum menschlichen Einfluß auf Fora und Vegetation. Theoretische Konzepte und ein Quantifizierungsansatz am Beispiel von Berlin (West). Landschaftsentwicklung und Umweltforschung 56., 1-280.

Kun Á. - Barta K. - Katona O. 2012: Az M43-as autópálya által indukált 2010-11-es belvíz talajtani hatásai, A VI. Magyar Földrajzi Konferencia, a MERIEXWA nyitókonferencia és a Geográfus Doktoranduszok Országos Konferenciájának Tanulmánykötete, Szegedi Tudományegyetem Természeti Földrajzi és Geoinformatikai Tanszék, 483-494.

Ladányi Zs. 2010: Tájváltozások értékelése a Duna-Tisza közi homokhátság egy környezet és klímaérzzékeny kistáján, az Illancson. PhD. disszertáció. Szegedi Tudományegyetem, Természeti Földrajzi és Geoinformatikai Tanszék, Szeged.

Leser H. 1997: Landschaftsökologie: Ansatz, Modelle, Methodik, Anwendung.- Stuttgart, Germany, 644.

Lóczy D. 2002: Tájértékelés, földértékelés. Dialóg Campus Kiadó, Budapest-Pécs, 307.

Lóki J. - Szabó J. 2006: Újabb adatok a Nyírség- Hajdúhát (Hajdúság) közötti tájhatár kérdéséhez. In: Kovács F. - Hevesi A. (szerk.) Földrajz, Tiszteletkötet Hahn György 70. születésnapjára. Egyetemi Kiadó, Miskolc, 101-115

Lucas, R. - Medcalf K. - Brown A. - Bunting P. - Breyer J. - Clewley D. - Keyworth S. Blackmore P. 2011: Updating the Phase 1 habitat map of Wales, UK, using satellite sensor data. ISPRS Journal of Photogrammetry and Remote Sensing 66., 81-102.

Lukács L. 2006: Prinz Gyula tájszemlélete és tájneveinek kartográfiai vonatkozásai. http://geography.hu/mfk2006/pdf/Luk\%E1cs\%20Lilla.pdf (Megtekintve: 2013.02.04.)

Marks R. 1979: Ökologische Landschaftanalyse. Mat. zur Raumordbubg, Band XXI Ruhr Univ, Bochum.

Marosi S. 1980: Tájkutatási irányzatok, tájértékelés, tájtipológiai eredmények. 13. MTA Földrajztudományi Kutatóintézet, Budapest.

Marosi S. - Somogyi S. (szerk.) 1990: Magyarország kistájainak katasztere I.-II., MTA FKI, Budapest, 1023.

Mas J.F. - Gao Y.- Pacheco J.A.N. 2010: Sensitivity of landscape pattern metrics to classification approaches. Forest Ecology and Management 259., 1215-1224.

Maull O. 1925: Politische Geographie. Verlag von Gebrüder Borntraeger, Berlin.

Maull O. 1936: Allgemeine vergleichende Länderkunde. In: Krebs N. (eds.) Länderkundfiche Forschungen, Krebs-Festschrift, 368. 
McBratney A.B. - Odeh I.O.A. 1997: Application of fuzzy sets in soil sciences: fuzzy logic, measurements and fuzzy classifications. Geoderma 77., 85-113.

McGarigal K. - Marks B.J. 1995: FRAGSTATS: spatial pattern analysis program for quantifying landscape structure. U.S.Department of Agriculture, Forest Service, Pacific Northwest Research Station, Portland, 122.

Megyeri J. 1997: Vasútépítéstan. Müegyetemi Kiadó, Budapest, 296.

Méri Á. - Körmöczi L. 2010: Temporal Pattern Analysis - a new algorithm for detecting patch size in plant populations. Tiscia 38., 3-9.

Mezősi G. 2003: A földrajzi táj. In: Borsy Z. (szerk.) Általános természetföldrajz. Nemzeti Tankönyvkiadó, Budapest, 807-817.

Mezősi G. 2009: Méretarány térben es időben. In: Tóth J. - Pál A. - Szónokyné Ancsin G. (szerk.) Tanulmány kötet Krajkó Gyula professzor úr tiszteletére. Szegedi Tudományegyetem TTK Gazdaság - és Társadalom - földrajzi Tanszék, 56-85.

Mezősi G. - Bata T. 2011/a: A földrajzi tájak határai. Földrajzi Közlemények 135/1,. 33-43.

Mezősi G. - Bata T. 2011/b: New result on landscape boundaries. Acta Geographica Debrecina, Landscape \& Environment 5/1., 1-11.

Mezősi G. - Meyer B.C. - Loibl W. - Aubrecht C. - Csorba P. - Bata T. 2012: Assessment of regional climate change impacts on Hungarian landscapes. Regional Environmental Change, DOI: 10.1007/s10113-012-0326-1

Mezősi G - Blanka V - Bata T - Kovács F - Meyer B 2013: Estimation of regional differences of wind erosion hazard in the Carpathian Basin. Agriculture, Ecosystems and Environment (megjelenés alatt)

MNA 1989: Magyarország Nemzeti Atlasza. Kartográfiai Vállalat, Budapest. 395.

Molnár Cs. - Molnár Zs. - Barina Z. - Bauer N. - Biró M. - Bodonczi L. - Csathó A.I. Csiky J. - Deák J.Á. - Fekete G. - Harmos K. - Horváth A. - Isépy I. - Juhász M. Kállayné-Szerényi J. - Király G. - Magos G. - Máté A. - Mesterházy A. - Molnár A. Nagy J. - Óvári M. - Purger D. - Schmidt D. - Sramkó G. - Szénási V. - Szmorad F. Szollát Gy. - Tóth T.- Vidra T. - Virók V. 2008: Vegetation-based landscape-regions of Hungary. Acta Botanica Hungarica 50., 47-58.

Molnár Zs. - Bíró M. - Horváth F. 2010: MÉTA. MTA ÖBKI, Vácrátót (CD)

Moser B. - Jaeger J. - Tappeiner U. - Tasser E. - Eiselt B. 2007: Modification of the effective mesh size for measuring landscape fragmentation to solve the boundary problem. Landscape Ecology 22/3., 447-459.

Mosimann T. 1984: Methodische Grundprinzipien für die Untersuchung von Geoökosystemen in der topologischen Dimension, Geomethodica 9., 31-65. 
Möllner M. - Lymburner L. - Volk M. 2007: The comparison index: A tool for assessing the accuracy of image segmentation. International Journal of Applied Earth Observation and Geoinformation 9., 311-321.

Mücher C.A. - Klijn J.A. - Wascher D.M. - Schaminé, J.H.J. 2010: A new European Landscape Classification (LANMAP): A transparent, flexible and user-oriented methodology to distinguish landscapes. Ecological indicators 10., 87-103.

Mucsi L. - Kovács F. - Henits L. - Tobak Z. - B. van Leeuwen - Szatmári J. - Mészáros M. 2007: Városi területhasználat és felszínborítás vizsgálata távérzékeléses módszerekkel. In: Mezősi G. (szerk.) Városökológia. Földrajzi Tanulmányok 1. JATEPress, 19-42.

Naveh Z. - Lieberman A. 1984: Landscape ecology: theory and application. SpringerVerlag, New York, NY, USA. 356.

Neef E. 1967: Die theoretischen Grundlagen der Landschaftslehre. H. Haack, Gotha, Leipzig, Germany.

Pécsi M. - Somogyi S. 1967: Magyarország természeti földrajzi tájai és geomorfológiai körzetei. Földrajzi Közlemények 15/4., 285-304.

Pécsi M. - Somogyi S. - Jakucs L. 1972: Magyarország tájtípusai. Földrajzi Értesítő 21/1., 512.

Pénzes R. 2009: Tájhatár vizsgálat Balmazújváros határában (Hortobágy és Hajdúhát). Diplomadolgozat. Természetföldrajzi es Geoinformatikai Tanszék, Debreceni Egyetem, 28 .

Prinz Gy. 1936: Magyar föld magyar faj, Magyar földrajz I., Magyarország tájrajza. Királyi Magyar Egyetemi Nyomda, Budapest. Hasonmás kiadás, Babits-Magyar Amerikai Kiadó Rt., Szekszárd.

Reck H. - Kaule G. 1993: Strassen und Lebensraume: Ermittlung und Beurteilung strassenbedingter Auswirkungen auf Pflanzen, Tiere und ihre Lebensraume. Forschung Strassenbau und Stassenverkehrstechnik, Heft 654. Bonn-Bad Godesberg, Germany, 230.

Regel v. C. - Winkler E. 1953: Zur Landschafts-Diskussion in der Sowjetgeographie. Eidg. techn. Hochschule, Geograph. Institut, 15.

Renetzeder C. - Schindler S. - Peterseil J. - Prinz M.A. - Mücher S. - Wrbka T. 2010: Can we measure ecological sustainability? Landscape pattern as an indicator for naturalness and land use intensity at regional, national and European level. Ecological Indicators 10., 39-48.

Riitters K.H. - O'Neill R.V. - Hunsaker C.T. - Wickham J.D. - Yankee D.H. - Timmins S.P. - Jones K.B. - Jackson B.L. 1995: A factor analysis of landscape pattern and structure metrics. Landscape Ecology 10., 23-29. 
Ryherd S. - Woodcock C. 1996: Combining spectral and texture data in the segmentation of remotely sensed images. Photogrammetric Engineering and Remote Sensing 62., 181-194.

Saunders D.A. - Hobbs R.J. - Margules C.R. 1991: Biological consequences of ecosystem fragmentation: a review. Conservation Biology 5., 18-32.

Schmithüsen J. 1963: Was is ein Landschaft? Erdkundliches Wissen, Schriftenreihe für Forschung und Praxis 9., 7-24.

Shi W. - Ehlers M. - Molenaar M. 2005: Uncertainties in integrated remote sensing and GIS. International Journal of Remote Sensing 26., 2911-2915.

Spellerberg I.F. 2002: Ecological effects of roads. Science Publishers, Ehnfield, New Hampshire, 251.

Sukopp H. 1969: Der Einfluß des Menschen auf die Vegetation. Vegetatio 17., 360-371.

Szabó Sz. 2009: Tájmetriai mérőszámok alkalmazási lehetőségeinek vizsgálata a tájanalízisben. Habilitáció, Debreceni Egyetem, 107.

Száva Kováts E. 1965: A földrajzi tájelmélet mai állása és alapvető filozófiai problémái. Földrajzi Értesítő 14., 277-289.

Szilágyi Zs. 2009: Sárrét posztmodern perspektívában. A táj történeti földrajza: Az egységesülés és széttagolódás formái. Tér és Társadalom 23/2., 113-133.

Szilassi P. 2012: Változó tájak: tendenciák, okok, következmények. Tájvédelmi Füzetek 2., $69-79$.

Szilassi P. - Bata T. 2012: Tájak természetességének értékelése tájmetriai módszerekkel Magyarország példáján. In: Farsang A. - Mucsi L. - Keveiné Bárány I. (szerk.) Táj - érték, lépték, változás GeoLitera, Szeged, 75-84.

Teleki P. 1936: A gazdasági élet földrajzi alapjai II. Centrum Kiadó, Budapest, 299.

Tóth G. 2006: A tervezett autópálya - építések tájvédelmi vonatkozásai. In: Csorba P. Fazekas I. (szerk.) Tájkutatás. Tájökológia Dialóg Campus, Pécs.

Troll C. 1950: Die geografische landschaft und ihre erforschung. Studium Generale 3. Springer, Heidelberg, German Democratic Republic, 163-181.

Trombulak S.C. - Frissell C.A. 2000: Review of ecological effects of roads on terrestrial and aquatic communities. Conservation Biology 14., 18-30.

van Andel J. - Aronson J. 2006: Restoration ecology. Blackwell Publishing, Malden, Oxford, Victoria

Wascher D. - Jongman R. (eds.) 2000: European Landscapes, Classification, assessment and conservation, European Environment Agency, Coppenhagen, 99.

Winter H.S. - Fischer A. 2010: Relative Quantitative Reference Approach for Naturalness Assessments of forests. Forest Ecology and Management 259., 1624-1632. 
Wrbka T. - Erb K.H. - Schulz N.B. - Peterseil J. - Hahn C. - Haberl H. 2004: Linking pattern and process in cultural landscapes. An empirical study based on spatially explicit indicators. Land Use Policy 21., 289-306.

Zebisch F. - Wechsung H. - Kenneweg M. 2004: Landscape response functions for biodiversity - assessing the impact of land-use changes at the county level. Landscape and Urban Planning 67., 157-172.

Zólyomi B. 1989: Természetes növénytakaró. In: Pécsi M. (szerk.) Magyarország nemzeti atlasza. Kartográfiai Vállalat, Budapest.

\section{Internetes hivatkozások:}

AGROTOPO: Agrotopográfiai Adatbázis. http://www.mta-taki.hu/hu/osztalyok/gislabor/agrotopo (Megtekintve: 2013.02. 04)

Clark Labs 2011: http://www.clarklabs.org/index.cfm (Megtekintve: 2013.02. 04)

EU Tájegyezmény 2000: http://www.termeszetvedelem.hu/index.php?pg $=$ sub 705 (Megtekintve: 2013.02.04)

Közlekedésfejlesztési Koordinációs Központ térképei:

http://www.kkk.gov.hu/pages/index.jsf?p=2\&id=6127 (Megtekintve: 2013.02. 04)

OTAB 1990: Országos Térinformatikai Alapadatbázis:

http://epa.oszk.hu/02100/02154/00003/pdf/EPA02154 RSGIS 2012 01 14-38.pdf 28. p.

(Megtekintve: 2013.02.04)

Shuttle Radar Topography Mission 2000: http://www2.jpl.nasa.gov/srtm/ (Megtekintve: 2013.02.04)

Térkép Kft 2011: http://www.hiszi-map.hu/index.php/terinformatika/(Megtekintve: 2013.02. 04)

Trimble 2011: http://www.ecognition.com/ (Megtekintve: 2013.02. 04)

Vasútvonal fejlesztések 2011: http://www.nif.hu/hu/fejlesztesek/vasutvonalak/ (Megtekintve: 2013.02.04)

1222/2011. (VI.29.) Kormányhatározat:

http://jogszabalykereso.mhk.hu/cgi bin/njt_doc.cgi?docid=138610.342073 (Megtekintve: 2013.02.04)

1996. évi LIII. törvény: http://net.jogtar.hu/jr/gen/hjegy doc.cgi?docid=99600053.TV

(Megtekintve: 2013.02.04) 


\section{Summary}

The landscapes are the characteristic, basic territorial units of geography. Although several methods are known for their interpretation, their reasonably accurate territorial definition is also important from theoretical and practical aspects. The geographical approach to landscape is mostly based on natural geography (a category of "natural history" - Marosi 1980), and according to this interpretation a section of the surface constitutes a unique, complex unit based on the structure and effect of the processes influencing it (Pécsi et al. 1972, Mezösi 2003). In the present days, the scientific explanations mostly use this approach as well.

Thus today in geography we regard the landscapes as entities whose frameworks are defined by natural factors. More accurately, distinct units with characteristic values are formed by all the (natural) landscape shaping factors, complemented by the characteristic entities of social activity, and in interaction with the artificial elements. The primacy of the natural landscape shaping factors and the role of the other landscape shaping factors in modifying this system of connections are expressed in this approach, and it is understandable that as a result, the use of the ethnographic, historical categories, which are difficult to delimit on the basis of natural factors, was often dismissed. Delimiting the borders of areas, units or entities is a universal problem in the spatial and landscape sciences, particularly when addressing natural systems or socio-ecological systems (Mezősi et al. 2012). Administrative areas are commonly applied as units for the statistical analysis of municipal, regional or countrywide surveys, but the administrative borders of these areas are fixed by politics and are often changed throughout history. Planners prefer to use well-defined and accurate borders for analytic units in diverse investigations (e.g., in spatial and landscape planning, impact assessment, climate change predictions and other applications).

In landscape ecology two main scientific approaches are applied to solve delineation problems: (1) the traditional method that combines a belt of shaping factors into a subjective delimitation of the unit or border (subjective segmentation), and (2) mathematical methods of segmentation via repeatable scientific methods using geo-statistics and digital geo-data (objective segmentation).

(1) The traditional belt method characterises the landscape based on landscape-shaping factors arranged hierarchically in micro-, meso- or macro-regions. Most landscape classifications available in Europe have been developed using these methods. The borders are generated by visually overlaying the borders of the constituent or shaping factors (e.g., geology, relief, soil, vegetation, climate, fauna and water household), which may be weighted. The delimitation process is performed by scientists, but it is not repeatable due to the 
subjective nature and the artistic drawing of the borders. The method by which the basic data are used for delimitation is generally unclear. The first examples using the traditional belt characterisation were applied approximately 100 years ago in Hungary using geomorphology in which the landform was used as the dominant character. Most of the later landscape or natural classifications were developed using geo-ecological and natural factors (Pécsi Somogyi 1967, Neef 1967, Haase 1976, 1991). The landscape classification for Hungary (Pécsi- Somogyi 1967) was made in the same way (using subjective segmentation). The detailed description of the micro-regions (landscape units) can be found in the first edition of The Cadastre of Hungary's Micro-landscapes (Marosi - Somogyi eds. 1990) or in its second revised and expanded edition (Dövényi eds. 2010).

However, the applied subjective method does not provide us with the opportunity to expect the same outcome of the repeated delimitation process, even using the same input data. Certain traditional delimitation problems of landscapes were discussed in the 1980s (Mosimann 1984 Forman - Godron 1986, Leser 1997). In Hungary problems of delimitation in the traditionally defined landscape units and suggestions for modifying the borders of the traditional micro- and meso-regions were mainly published in the last decade. (e.g., Csapó 2008, Szilágyi 2009, Lóki - Szabó 2006, Pénzes 2009, Benedek 1996, Flórián 2008, Ladányi 2010, Deák 2010).

(2) Image segmentation (i.e., multiresolution segmentation) enables the researcher to address a number of spatial factors in an integrative manner and treats landscapes as a complex system. Image segmentation methods were first developed in the 1970s (Haralick 1973, Haralick - Shapiro 1985). The segmentation approach was designed to analyse remotely-sensed (spectral) data (Burnett - Blaschke 2003, Haralick - Shapiro 1985, Ryherd Woodcock 1996, Baatz - Schäpe 2000, Bock et al. 2005, Boutin et al. 2008, Lucas et al. 2011), but the method is also applicable to vector data (Mücher at al. 2010, Renetzeder et al. 2010). Several new segmentation algorithms and applications have been tested in geo-science applications in recent years, but per-pixel analyses are often criticised, as Blaschke - Strobl (2001) and Burnett - Blaschke (2003) have noted in detail. Object-based image analysis is useful to extend the landscape analysis beyond the pixel classifications and takes into account the sizes, shapes and positions of the objects (Blaschke - Strobl 2001, Drăgut - Blashke 2006).

Several studies have clarified that multiresolution segmentation is an acceptable method for the delimitation of spatial units. This method allows the boundary calculations to be repeated in a transparent manner (Blaschke - Strobl 2001, Mücher et al. 2010). 
The weak points of subjective segmentation considered, my aim was to create a new objective landscape delimitation for Hungary, which uses mathematical/statistical measures to fix the problems mentioned above. In order to prepare a replicable objective landscape segmentation, which excludes weighting factors as well as subjective components, I employed multiresolution segmentation, which also provides a solution for integrating of different landscape shaping factors.

Multiresolution segmentation was used by the European Landscape Character Assessment Initiative (ELCAI 2005) for the European Landscape Typology and Map (LANMAP). However, in the LANMAP application, only four shaping factors (climate, relief, lithology and land cover) were used at the large-scale and $1 \mathrm{~km}^{2}$ spatial resolution. My aim was to improve this method by using better spatial resolution (at a higher scale) and involving more landscape shaping factor.

In the segmentation process, classified factors with quantifiable geo-information data were taken into consideration. Thus, other factors that incorporate the social sciences, ethnography, and cultural sciences are not included although they may be important in other applications (e.g., regional planning). The aim of our study was to delimit the regional landscape areas using these neutral (unweighted) units. The new segmentated landscape units (SLU) have patterns and ecological parameters similar to those of the traditionally defined landscape units (TLU) (Number of patches, Mean patch size, Mean fractal dimension, and Core area index. The applied method for delimiting the SLU uses more detailed data than the LANMAP (Mücher et al. 2010), and additional parameters in much smaller territorial units were included in the segmentation process.

In this study, a "classical segmentation validation" could not be elaborated upon because no generally accepted basis data for the validation are available for the new SLU. Thus, the borders of the SLU were compared in a stepwise analysis. A complex comparative analysis showed that the locations of the borders of the SLU are similar to the borders of the Vegetation based landscape units (VLU), with an overlap area of $66.33 \%$.

Each complex comparative analysis demonstrate that the applied multiresolution segmentation is well suited to serve as a new landscape unit system for Hungary. At the same time, the SLU can avoid costly fieldwork needed to delimit the landscape units if sufficient and good quality data are available for multiresolution segmentation. In comparison with the LANMAP units, the SLU used additional landscape shaping factors and a higher spatial resolution. 
The regional comparative analyses showed that in three regions, the applied multiresolution segmentation method is highly applicable at the micro-region scale level to delimit landscape units. These analyses also demonstrated that the SLU offers a new landscape unit system for Hungary. The multiresolution segmentation methodology combined with fuzzy set methods and based on multiple layers of geo-data is useful and objective for delimiting landscape units at various hierarchical levels, e.g., in landscape or territorial planning.

In contrast, landscape or natural borders and entities are seldom clear and distinct due to the transitional character of nature. Therefore, a landscape-based analysis should employ integrated units that require bordering ecotones, the ecotones represent zones and are not represented by simple lines on the map. An appropriate technique used to treat the ecotones as boundaries and apply them to distinct units such as objects (e.g., objects of decision-making) without treating the ecotones as unique pathes is the fuzzy logic approach rather than traditional Boolean logic techniques (Ji 2002, Arnot - Fisher 2007, Chong et al. 2010, Mezősi - Bata 2011). Fuzzy logic techniques can be combined with spatial metrics, as shown by McGarigal - Marks (1995) or Herzog et al. (2001).

This analysis does not primarily aim at the modification of landscape boundaries, but it presents their analysis with a different approach, where the often zone-like appearance of the boundaries is emphasised. This is in line with our experience that the boundaries are not static (we have data of this fact in connection with the vegetation - e.g., Méri - Körmöczi 2010), which demonstrates the relative steadiness of the core areas and the pulsation of the ecotones depending on the types that constitute them, that is, they are not rigid categories. Our analyses show that the landscape boundaries usually represent a transition zone of a few hundred meters to a few kilometres in width. This problem concerns the stability of the landscapes and their sensitivity to the changes. It is known that the landscape can be regarded as system where changes of the anthropogenic influence (but generally that of one landscape shaping elements) can cause the instability of the system and induce changes. The sensitivity of the landscape is interpreted as the swift reaction to the disturbing effects, which indicates the conditional instability of the landscape system.

In my research I analyzed spatial and temporal changes in fragmentation caused by artificial barriers to determine the sensitivity and stabilitity of the ecosystem and landscape units. Artificial barriers such as roads, railways and settlements are capable to place a major change on the unity of any landscape. Roads and railways split the continuous landscape units, thus basically modifying their ecological properties. (Forman - Alexander 1995, Trombulak Frisell 2000, Forman et al. 2003). Due to fragmentation the ecological stability in the 
fragmented parts deteriorates and the natural ecosystem flow processes in substance and energy could be affected. (Csorba 2005, Moser et al 2007).

The more artificial barriers turn up in the landscape, the more fragmented it will be. The once continuous landscape unit will be divided into two or more patches, its ecological stability will flag. To measure the degree of fragmentation caused by the artificial barriers the most suitable method is to calculate together the following landscape metrics: "Number of Patches", the "Divison", the "Splitting Index" and the "Effective Mesh Size" (with two different calculating methods).

By comparing the state of fragmentation in 1990 and in 2011 I got a comprehensive view about the changes of the landscape sensitivity, and by involving documentations about longterm plans for upgrading the Hungarian highway and major roads network (up to year 2027) into my research I got some information about the predictable future as well.

In respect of the traditionally defined landscape units four „sensitivity-stability groups” has been created using the value changes of the Effective Mesh Size between 1990 and 2011, and between 2011 and 2027. Group 1 represents landscapes which are expected to be more sensitive and have a gradual loss of stability in habitat due to the expansion of the artificial barriers. Some landscape units (Group 2) may only be sensitive in the future, others (Group 3) may be heading for a more stable future and there are some landscapes (Group 4) which were not and will not be affected by fragmentation caused by the artificial barriers.

The advantage of the applied method is that landscape metrics would be of considerable help in choosing the location of artificial barriers when selecting the future Highway tracks and warnings could be made about landscape units the natural balance of which wouldn't tolerate more such barriers. (Girvetz et al. 2008., Jaeger et al. , 2007, Fu et al. 2010)

To achieve this however, further analyses (Keveiné Bárány 2010) in landscape ecology should be made by involving various data (e.g., land cover maps - Mucsi et al. 2007, Szilassi Bata 2012; national ecological network data - Tóth 2006; or field measurement data: e.g., habitat mapping - Czúcz et al 2008, measurement of the useness of ecoducts - Hardy et al. 2003). 


\section{Mellékéletek}

1. Sz. melléklet: Magyarország tájföldrajzi egységei

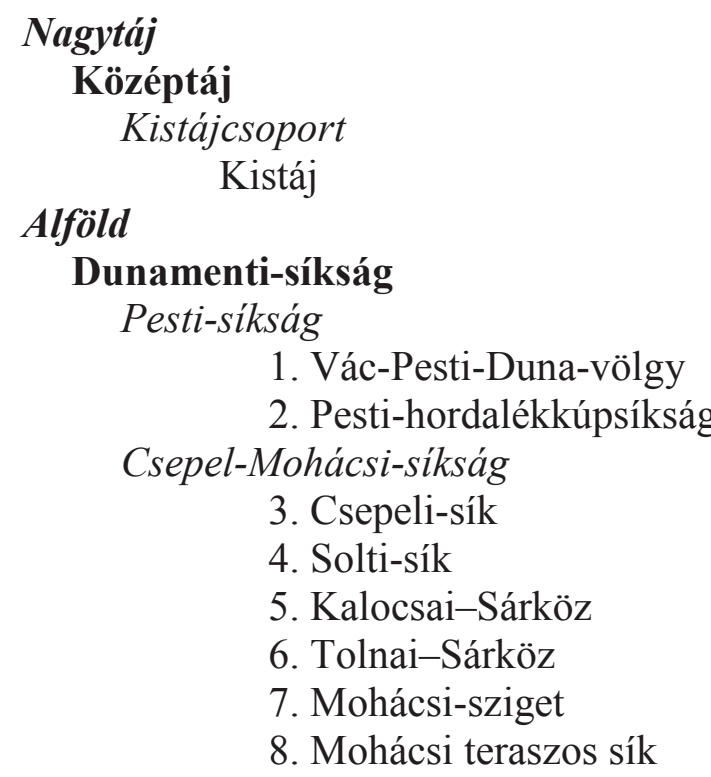

Duna-Tisza közi síkvidék

9. Gerje-Perje-sík

10. Pilis-Alpári-homokhát

11. Kiskunsági-homokhát

12. Bugaci-homokhát

13. Dorozsma-Majsaihomokhát

14. Kiskunsági-löszöshát

Bácskai-síkvidék

15. Illancs

16. Bácskai löszös síkság

\section{Mezőföld \\ Észak-Mezöföld \\ 17. Érd-Ercsi-hátság \\ 18. Váli-víz síkja}

Duna-Sárvíz köze

19. Közép-Mezőföld

20. Velencei-medence

21. Sárrét

22. Sárvíz-völgy

23. Dél-Mezőföld

Nyugat-Mezöföld

24. Enyingi-hát

25. Kálóz-Igari-löszhátak

26. Sió-völgy

\section{Drávamenti-síkság}

27. Dráva-sík

28. Fekete-víz síkja

29. Nyárád-Harkányi-sík

Felső-Tiszavidék

30. Beregi-sík
31. Szatmári-sík

32. Bodrogköz

33. Rétköz

Közép-Tiszavidék

Közép-tiszai ártér

34. Taktaköz

35. Borsodi-ártér

36. Hevesi-ártér

37. Szolnoki-ártér

38. Jászság

Nagykunság

39. Tiszafüred-Kunhegyesisík

40. Szolnok-Túri-sík

41. Tiszazug

42. Hortobágy

Alsó-Tiszavidék

43. Marosszög

44. Dél-Tisza-völgy

Észak-Alföldi hordalékkúp-síkság

Tápió-Galga-Zagyvavidék

45. Hatvani-sík

46. Tápióvidék

Gyöngyös-Hevesvidék

47. Gyöngyösi-sík

48. Hevesi-sík

Borsod-Zempléni-síkvidék

49. Borsodi-Mezőség

50. Sajó-Hernád-sík

51.Harangod

Nyírség

Nyírségi homokvidék

52. Közép-Nyírség

53. Északkelet-Nyírség

54. Délkelet-Nyírség

55. Dél-Nyírség

56. Nyugati- vagy Löszös-

Nyírség

\section{Hajdúság}

57. Hajdúhát

58. Dél-Hajdúság 
Berettyó-Körösvidék

Berettyóvidék

59. Dévaványai-sík

60. Nagy-Sárrét

61. Berettyó-Kálló köze

62. Érmelléki löszös hát

Körösvidék

63. Bihari-sík

64. Kis-Sárrét

65. Körösmenti-sík

Körös-Maros köze

Békés-Csanádi-hát

66. Csanádi-hát

67. Békési-hát

Békés-Csongrádi-sik

68. Békési-sík

69. Csongrádi-sík

70. Körösszög

\section{Kisalföld \\ Győri-medence}

Szigetköz-Mosoni síkság

71. Szigetköz

72. Mosoni-sík

Fertö-Hanság-medence

73. Fertő-medence

74. Hanság

Rábaköz

75. Kapuvári-sík

76. Csornai-sík

Marcal-medence

77. Marcal-völgy

78. Kemenesalja

79. Pápa-Devecseri-sík

Komárom-Esztergomi-síkság

80. Győr-Tatai-teraszvidék

81. Igmánd-Kisbéri-medence

82. Almás-Táti-Duna-völgy

Nyugat-magyarországi-peremvidék Alpokalja

Soproni-hegység

83. Soproni-hegység

84. Fertőmelléki-dombság

85. Soproni-medence

Köszegi-hegység - Vas-hegy

86. Kőszegi-hegység

87. Vas-hegy és

Köszeghegyalja

88. Pinka-sík

Felsö-Örség-Vasi-Hegyhát

89. Felső-Örség
90. Vasi hegyhát

Sopron-Vasi-síkság

91. Ikva-sík

92. Répce-sík

93. Gyöngyös-sík

94. Rábai teraszos sík

95. Rába-völgy

\section{Kemeneshát}

96. Alsó-Kemeneshát

97. Felső-Kemeneshát

\section{Zalai-dombvidék}

Nyugat-Zalai-dombság

98. Felső-Zala-völgy

99. Kerka-vidék (Hetés)

100. Közép-Zalai-dombság

(Göcsej)

Kelet-Zalai-dombság

101. Egerszeg-Letenyei-

dombság

102. Principális-völgy

103. Zalaapáti-hát

104. Alsó-Zala-völgy

105. Zalavári-hát

Muravölgyi-sík

106. Mura-balparti sík

\section{Dunántúli-dombság}

\section{Balaton-medence}

107. Kis-Balaton-medence

108. Nagyberek

109. Somogy-parti sík

110. Balaton

111. Balatoni-Riviéra

112. Tapolcai-medence

113. Keszthelyi-Riviéra

Külső-Somogy

114. Nyugat-Külső-Somogy

115. Kelet-Külső-Somogy

116. Dél-Külső-Somogy

\section{Belső-Somogy}

117. Marcali-hát

118. Kelet-Belsö-Somogy

119. Nyugat-Belső-Somogy

120. Közép-Dráva-völgy

Mecsek és Tolna-Baranyai-dombvidék

Mecsekvidék

121. Mecsek-hegység

122. Baranyai-Hegyhát

Tolnai-dombság

123. Völgység

124. Tolnai-Hegyhát 
125. Szekszárdi-dombság

Baranyai-dombság

126. Pécsi-síkság

127. Geresdi-dombság

128. Villányi-hegység

129. Dél-Baranyai-dombság

Zselic

130. Észak-Zselic

131. Dél-Zselic

\section{Dunántúli-középhegység \\ Bakonyvidék}

Keszthelyi-hegység

132. Tátika-csoport

133. Keszthelyi-fennsík

Balaton-felvidék

134. Badacsony-Gulács-

csoport

135. Balaton-felvidék és

kismedencéi

136. Vilonyai-hegyek

Déli-Bakony

137. Veszprém-

Nagyvázsonyi-medence

138. Kab-hegy-Agár-tető

csoport

139. Sümeg-Tapolcai hát

140. Devecseri-Bakonyalja

Északi-Bakony

141. Öreg Bakony

142. Bakonyi-kismedencék

143. Keleti-Bakony

144. Veszprém-Devecseriárok

Bakonyalja

145. Pápai-Bakonyalja

146. Pannonhalmi-dombság

147. Súri-Bakonyalja

Vértes-Velencei-hegyvidék

Véretsalji-dombság

148. Bársonyos

149. Által-ér-völgy

150. Móri-árok

Vértes-hegység

151. Vértes-fennsík

152. Vértes peremvidéke

153. Gánti-medence

Velencei-hegység és környéke

154. Zámolyi-medence

155. Sörédi-hát

156. Lovasberényi-hát
157. Velencei-hegység

\section{Dunazug-hegyvidék}

Gerecsevidék

158. Nyugati-Gerecse

159. Központi-Gerecse

160. Keleti-Gerecse

161. Gerecsei kismedemcék

Bicskei-Zsámbéki-medence

162. Etyeki-dombság

163. Zsámbéki-medence

Budai-hegység

164. Budai-hegyek

165. Tétényi-fennsík

166. Budaőrsi-és Budakeszi-

medence

Pilis-hegység

167. Pilisi-hegyek

168. Pilisi medencék

Észak-magyarországi-középhegység

Visegrádi-hegység

169. Visegrádi-Dunakanyar

170. Visegrádi-hegység

\section{Börzsöny}

171. Központi-Börzsöny

172. Börzsönyi kismedencék

173. Börzsönyi-peremhegység

\section{Cserhátvidék}

Nyugati-Cserhát

174. Kosdi-dombság

175. Nézsa-Csővári-dombság

Keleti-Cserhát

176. Központi-Cserhát

177. Galga-völgy

178. Ecskendi-dombság

179. Cserhátalja

Északi-Cserhát

180. Terényi-dombság

181. Szécsényi-dombság

Karancsság

182. Karancs

183. Litke-Etesi-dombság

Gödöllö-Monori-dombság

184. Gödöllői-dombság

185. Monor-Irsai-dombság

\section{Mátravidék}

Központi-Mátra

186. Magas-Mátra

187. Nyugati-Mátra

188. Déli-Mátra

Mátraalja

189. Keleti-Mátraalja 
190. Nyugati-Mátraalja

191. Mátralába

192. Parád-Recski-medence

\section{Bükkvidék}

Központi-Bükk

193. Bükk-fennsík

194. Északi-Bükk

195. Déli-Bükk

Bükkalja

196. Tárkányi-medence

197. Egri-Bükkalja

198. Miskolci-Bükkalja

Bükklába

199. Tardonai-dombság

200. Upponyi-hegység

Aggtelek-Rudabányai-hegyvidék

Aggteleki-karszt

201. Aggteleki-hegység

202. Alsó-hegy

Rudabányai-Szalonnai-hegység 203. Rudabányai-hegység

204. Szalonnai-hegység

205. Bódva-völgy

206. Tornai-dombság

Tokaj-Zempléni-hegyvidék

Zempléni-hegység

207. Központi-Zemplén

208. Abaúji-Hegyalja

Tokaj-Hegyalja

209. Tokaji-hegy
210. Szerencsi-dombság

Hegyköz

211. Hegyalja

212. Hegyközi-dombság

213. Vitányi-rögök

Észak-Magyarországi-medencék

Ipoly-völgy és Nógrádi-medence

214. Alsó-Ipoly-völgy

215. Középső-Ipoly-völgy

216. Nógrádi-medence

Felsö-Zagyva-Tarna közi dombság

217. Zagyva-völgy

218. Medves-vidék

219. Felső-Tarnai-dombság

220. Tarna-völgy

Gömör-Hevesi-dombság

221. Ózd-Egercsehi-medence

222. Pétervásári-dombság

Borsodi-medence

223. Sajó-völgy

224. Putnoki-dombság

Cserehát

225. Szendrői-rögvidék

226. Rakacai-völgymedence

227. Keleti-Cserehát

228. Nyugati-Cserehát

Hernád-völgymedence

229. Hernád-völgy

230. Szerencsköz 


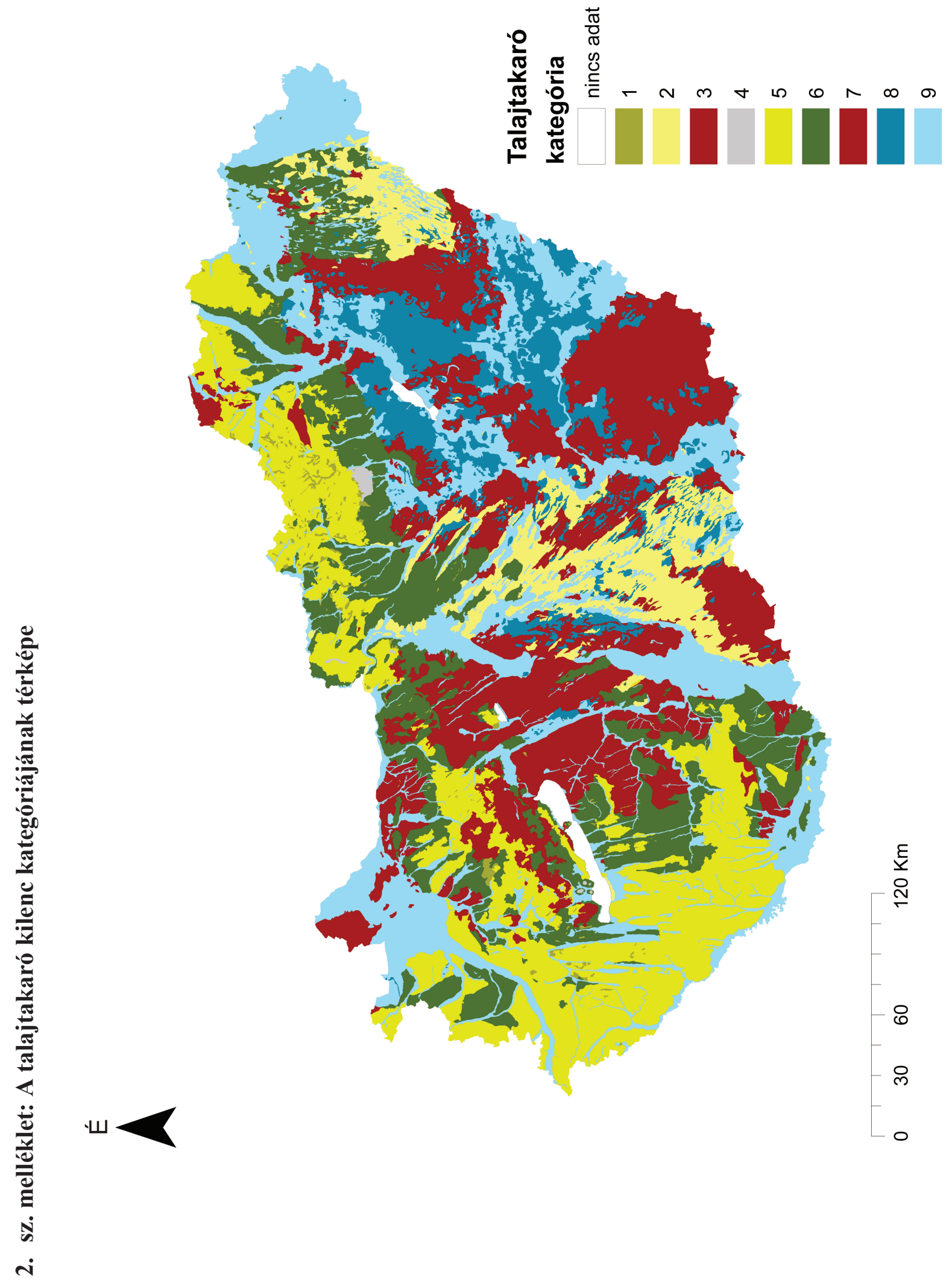




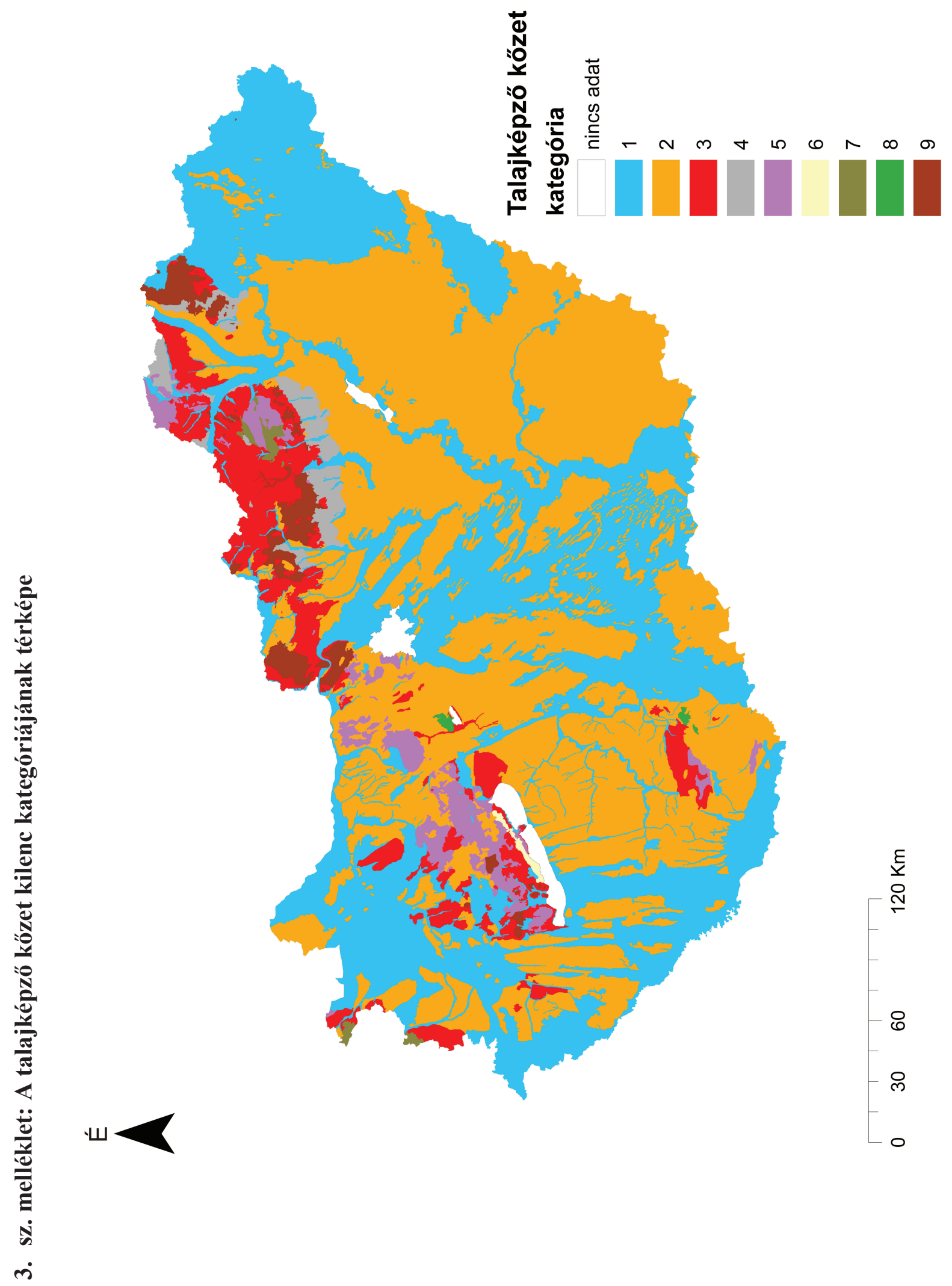




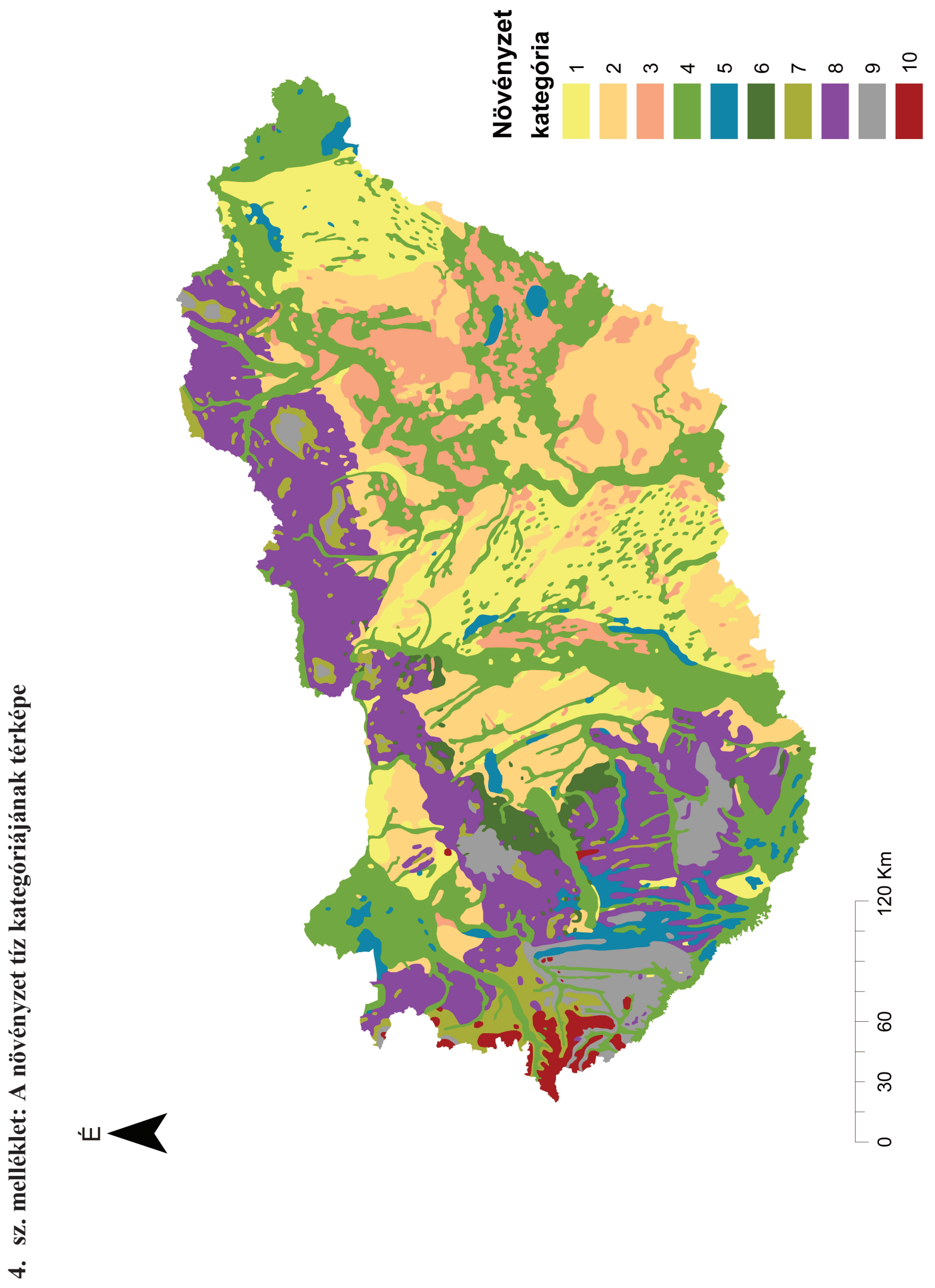




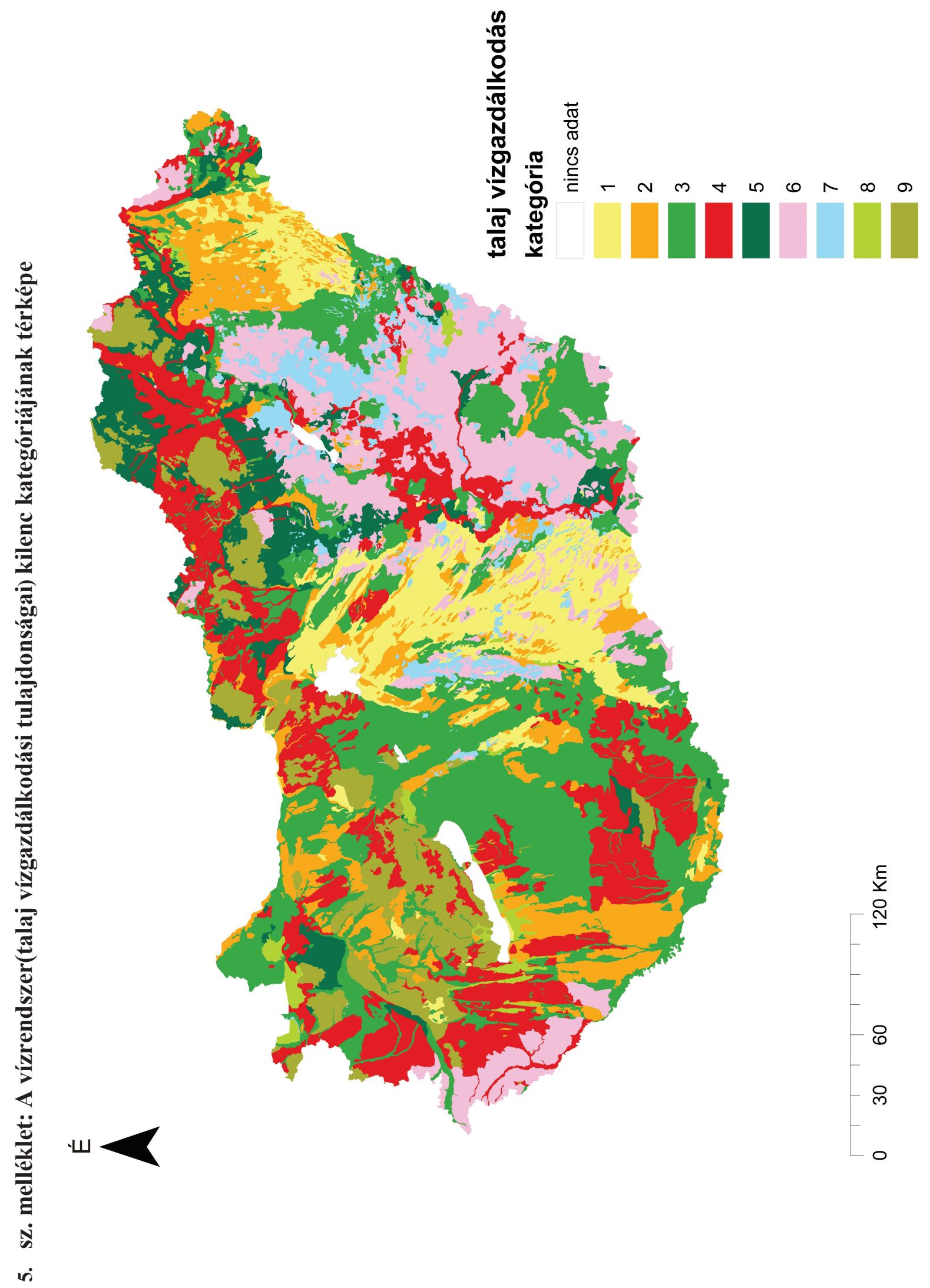




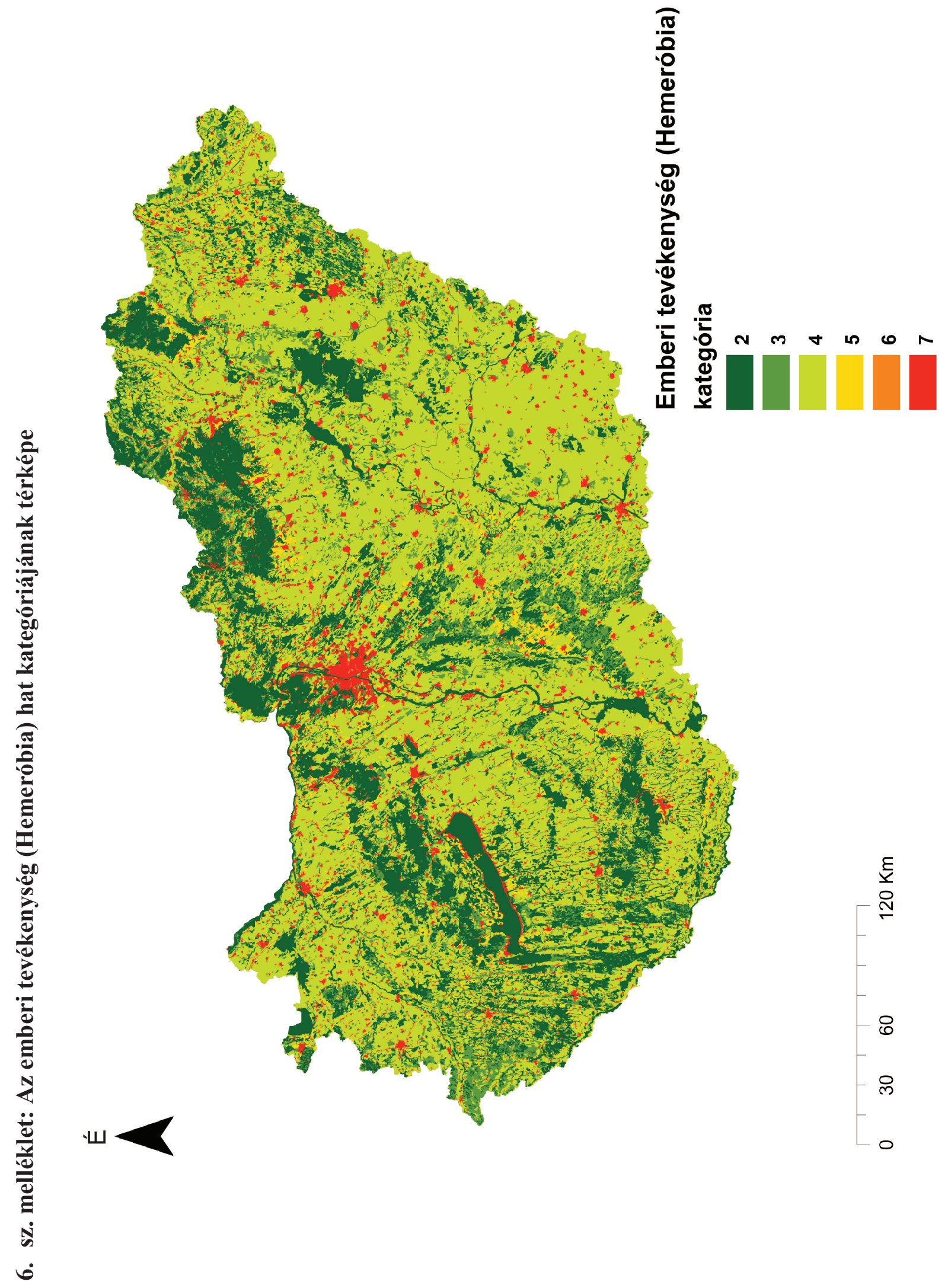




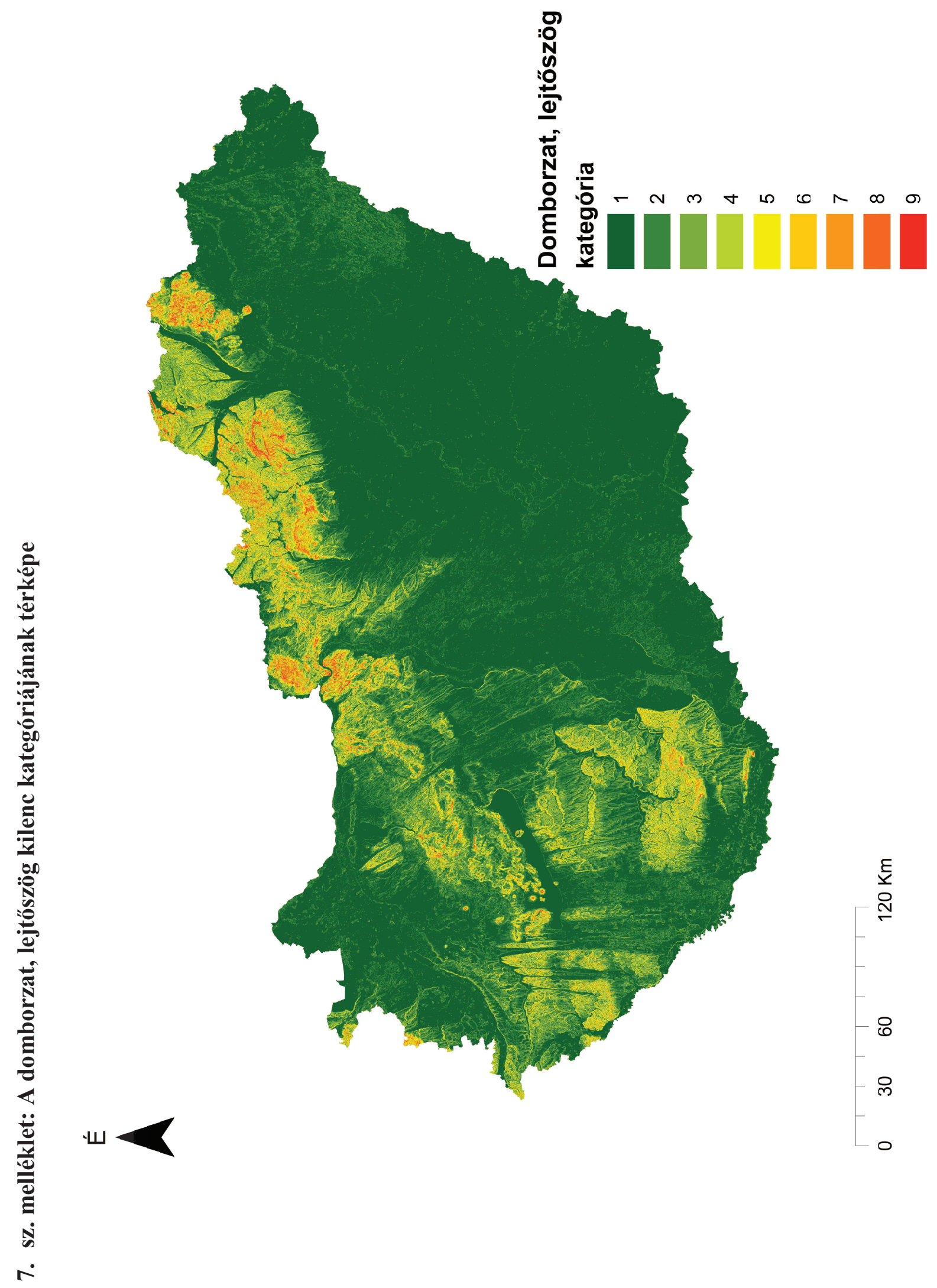




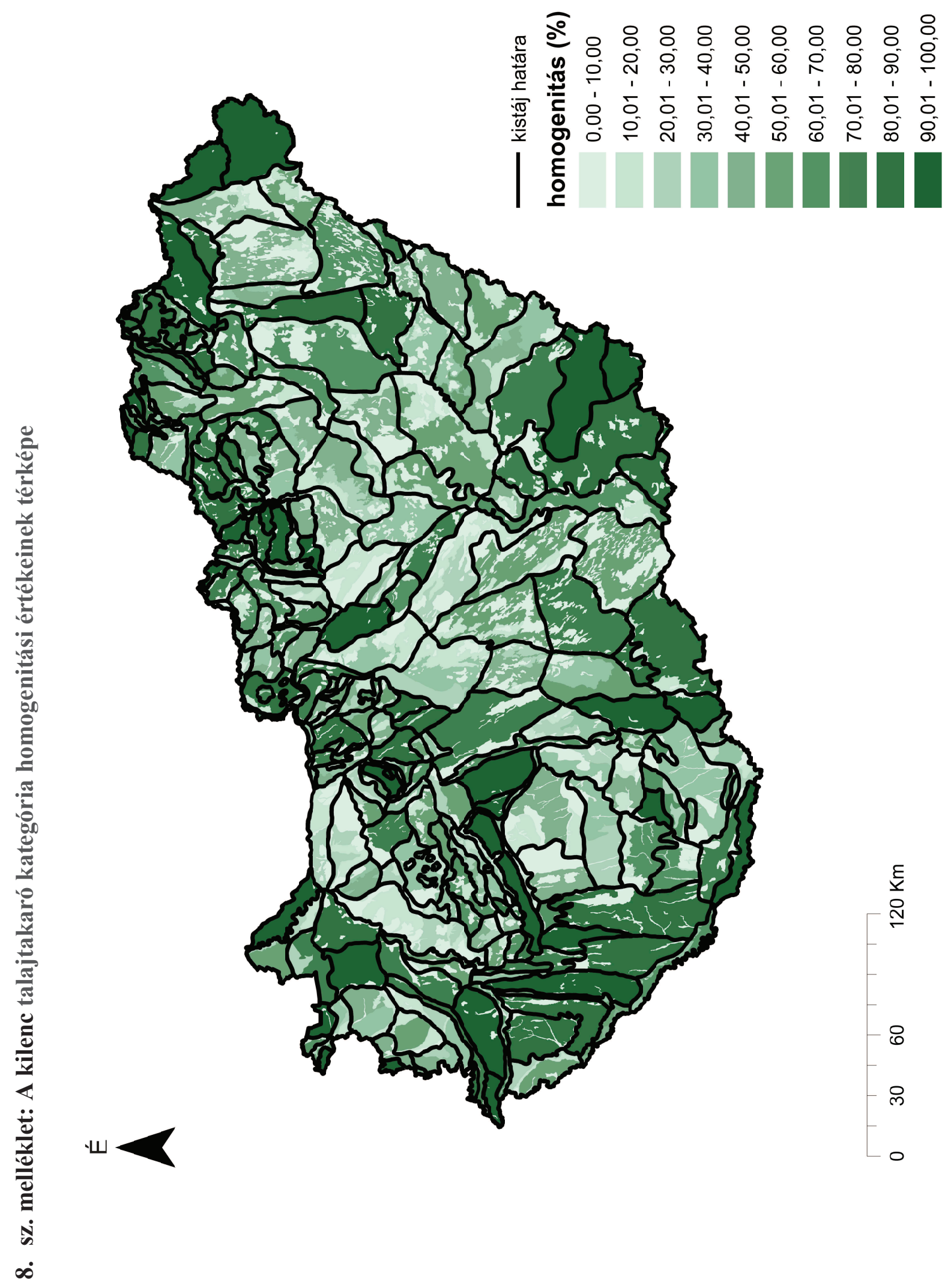




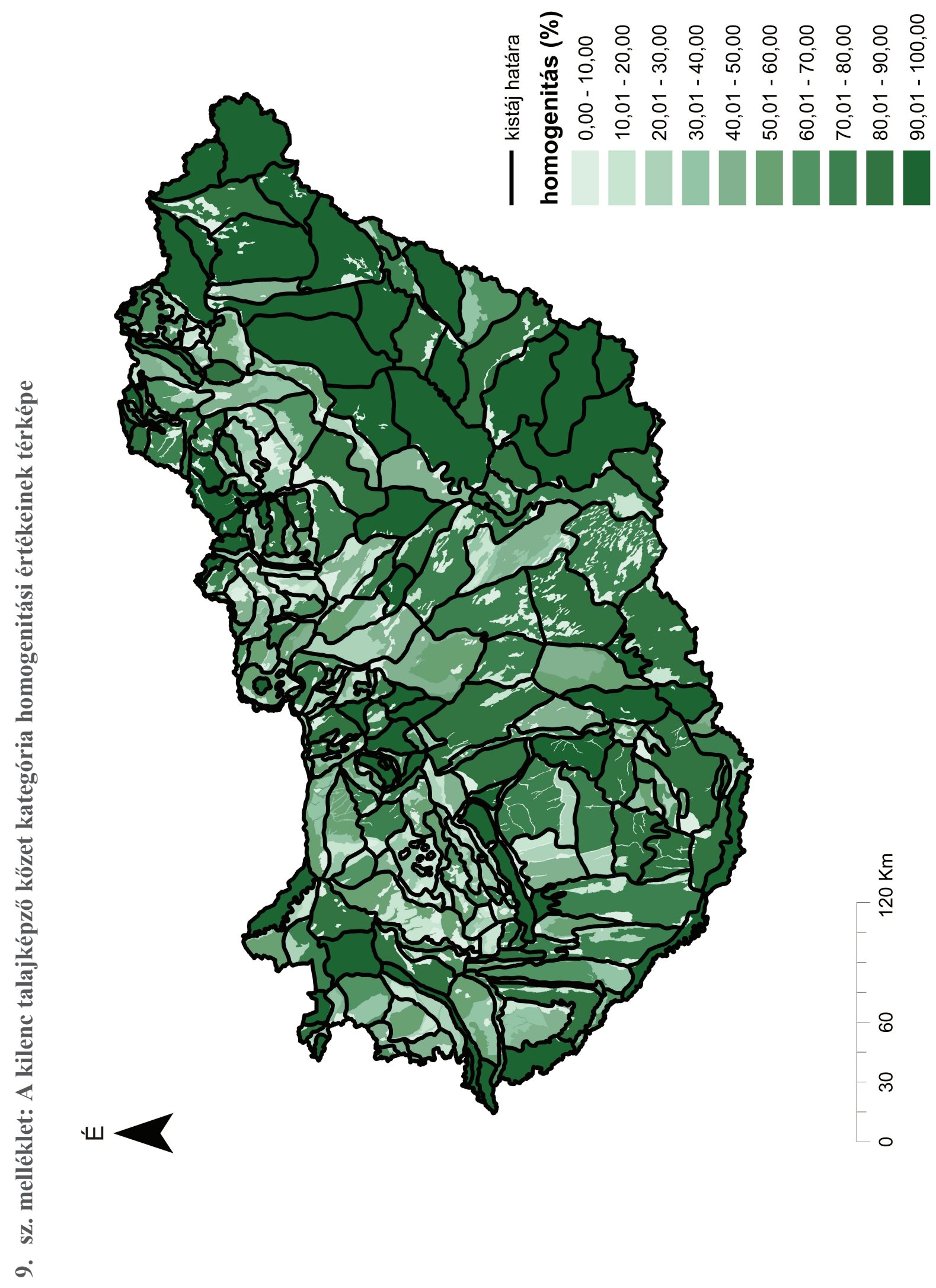




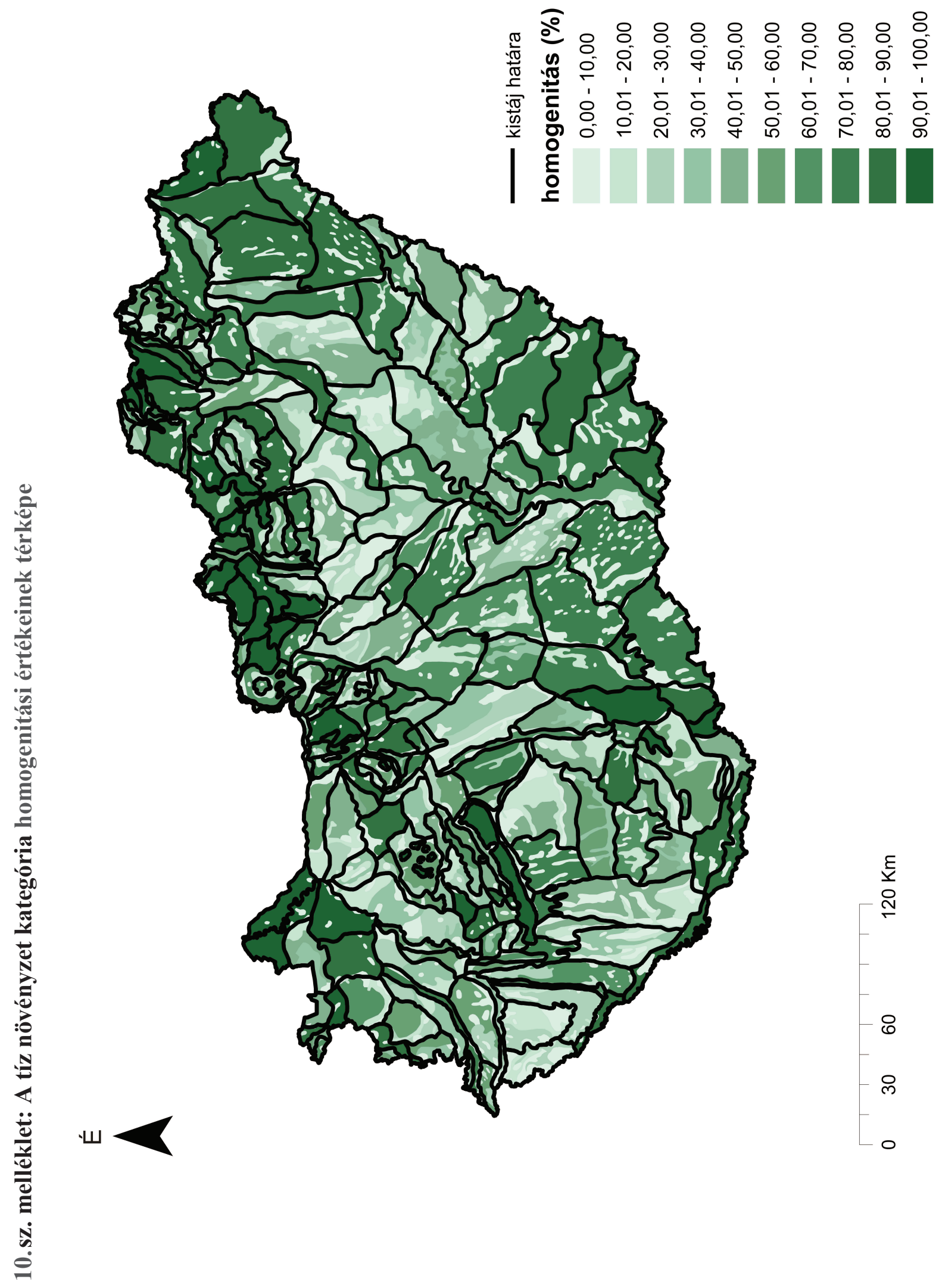


过
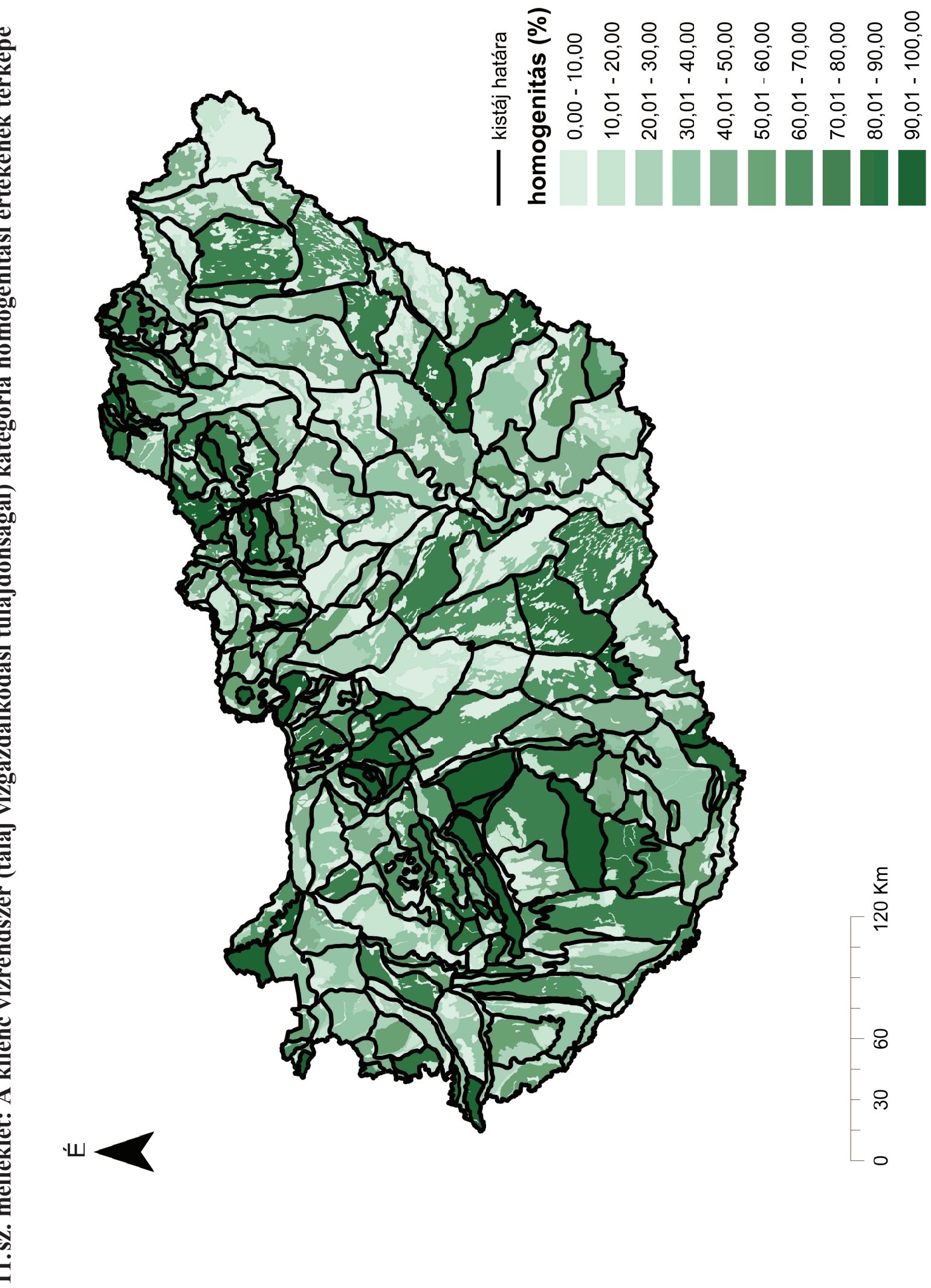


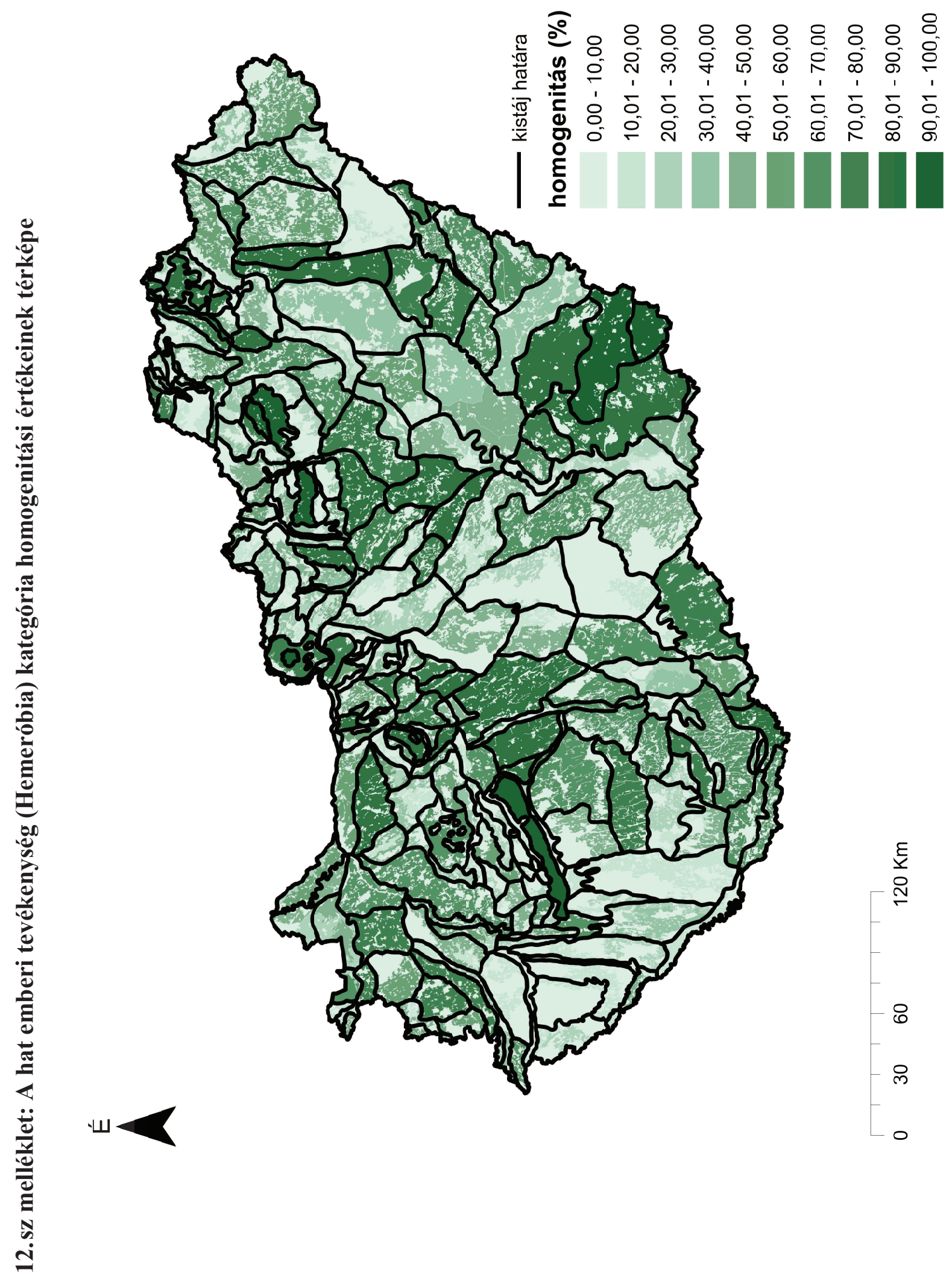




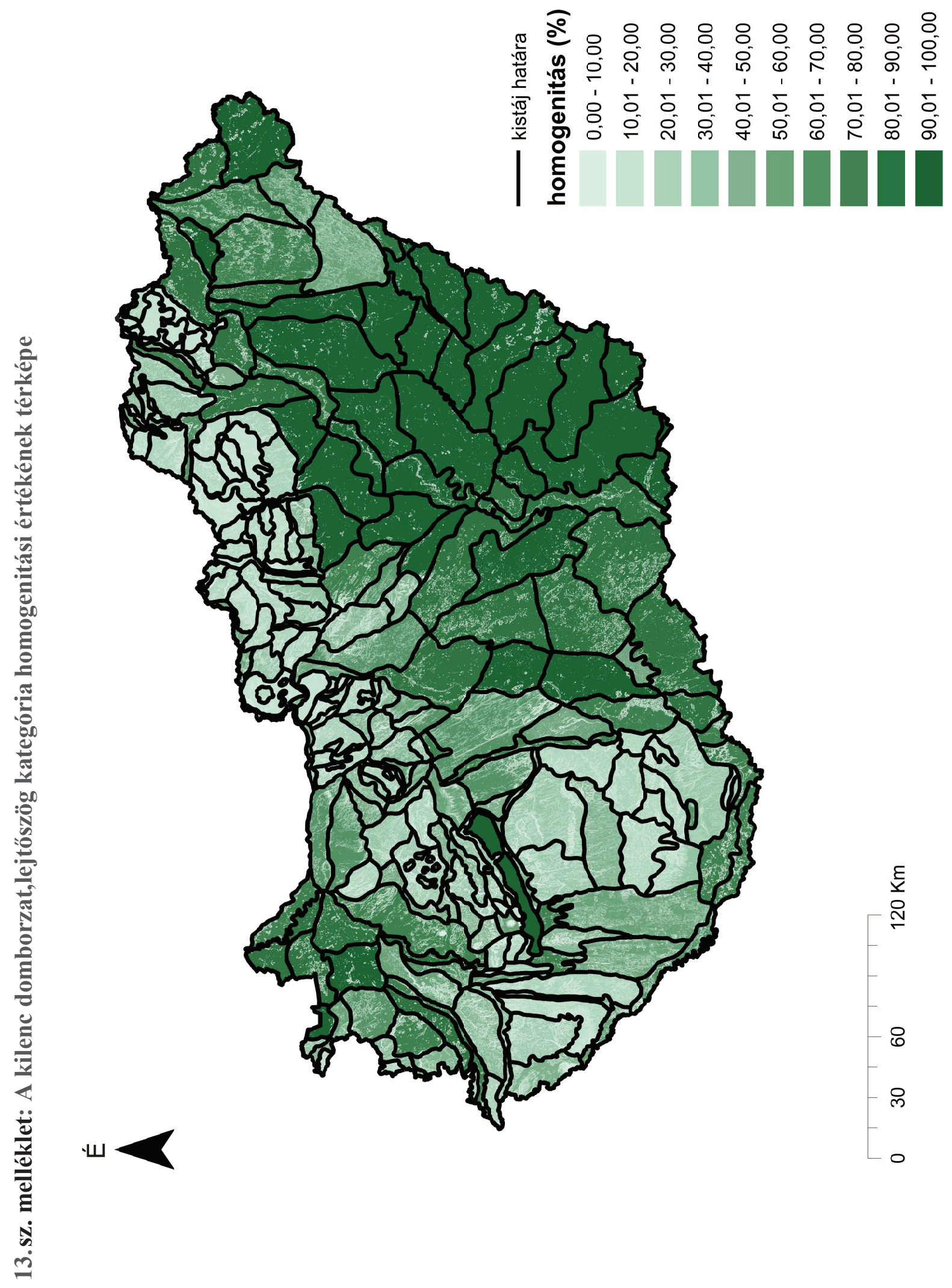



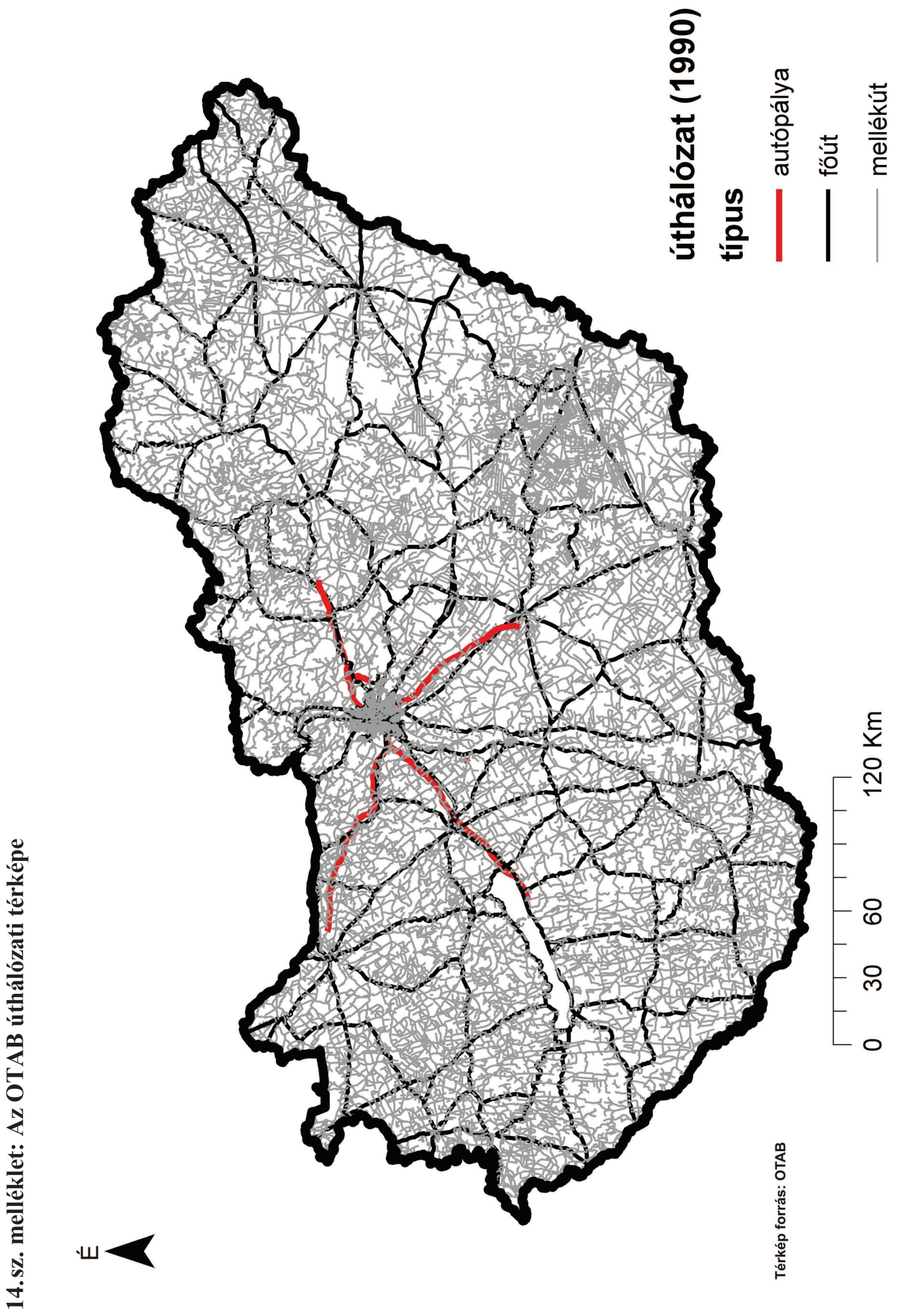


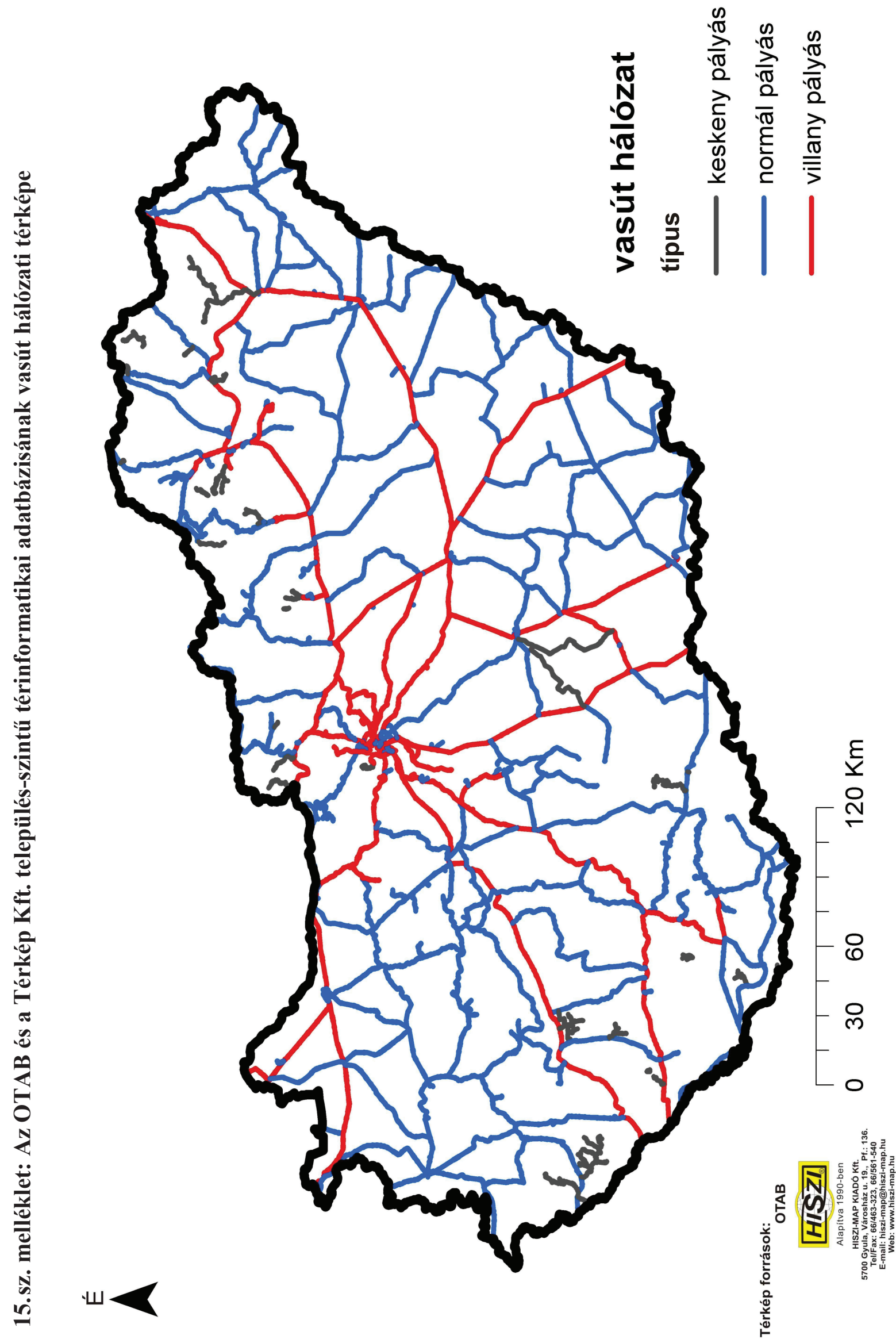




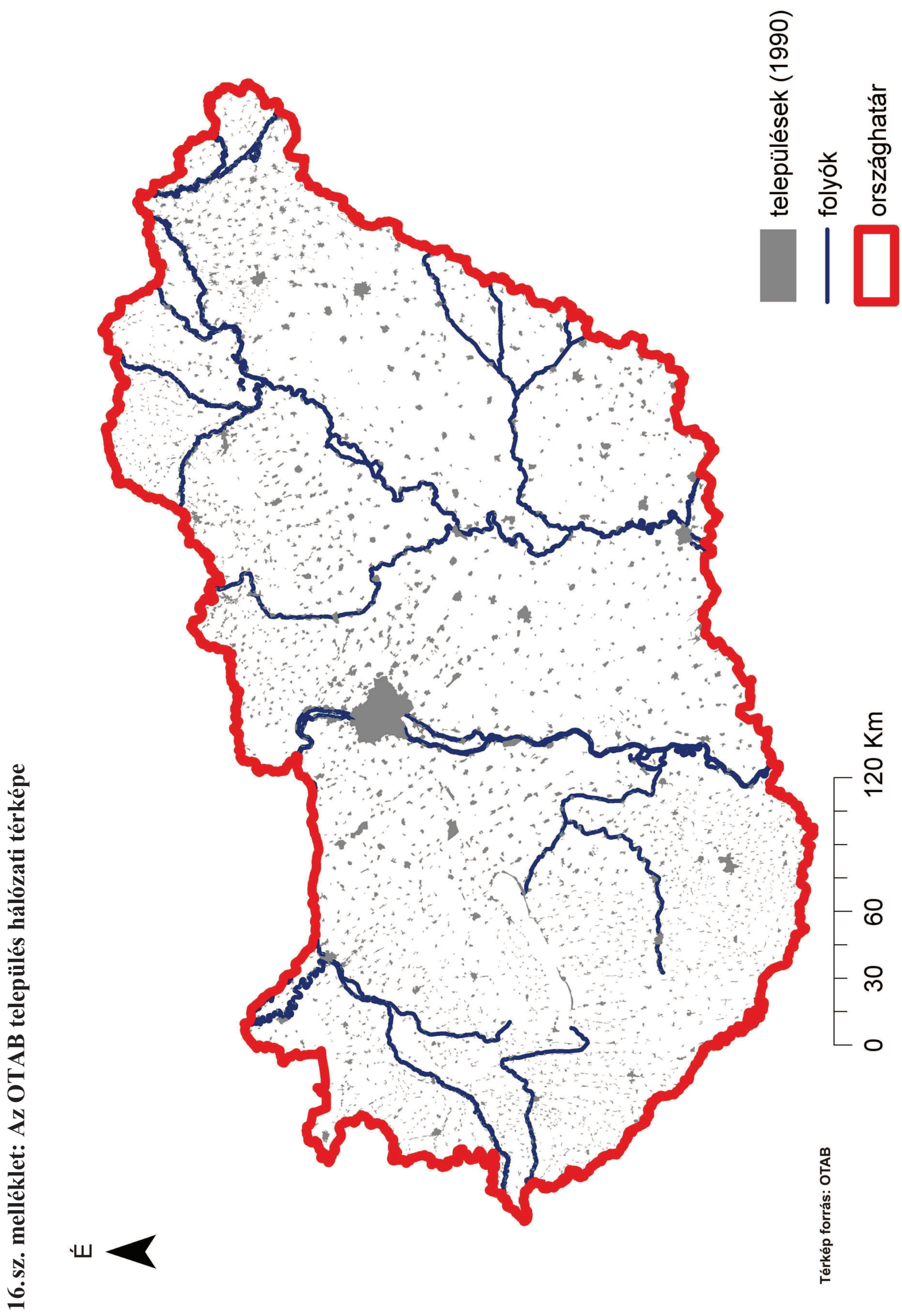



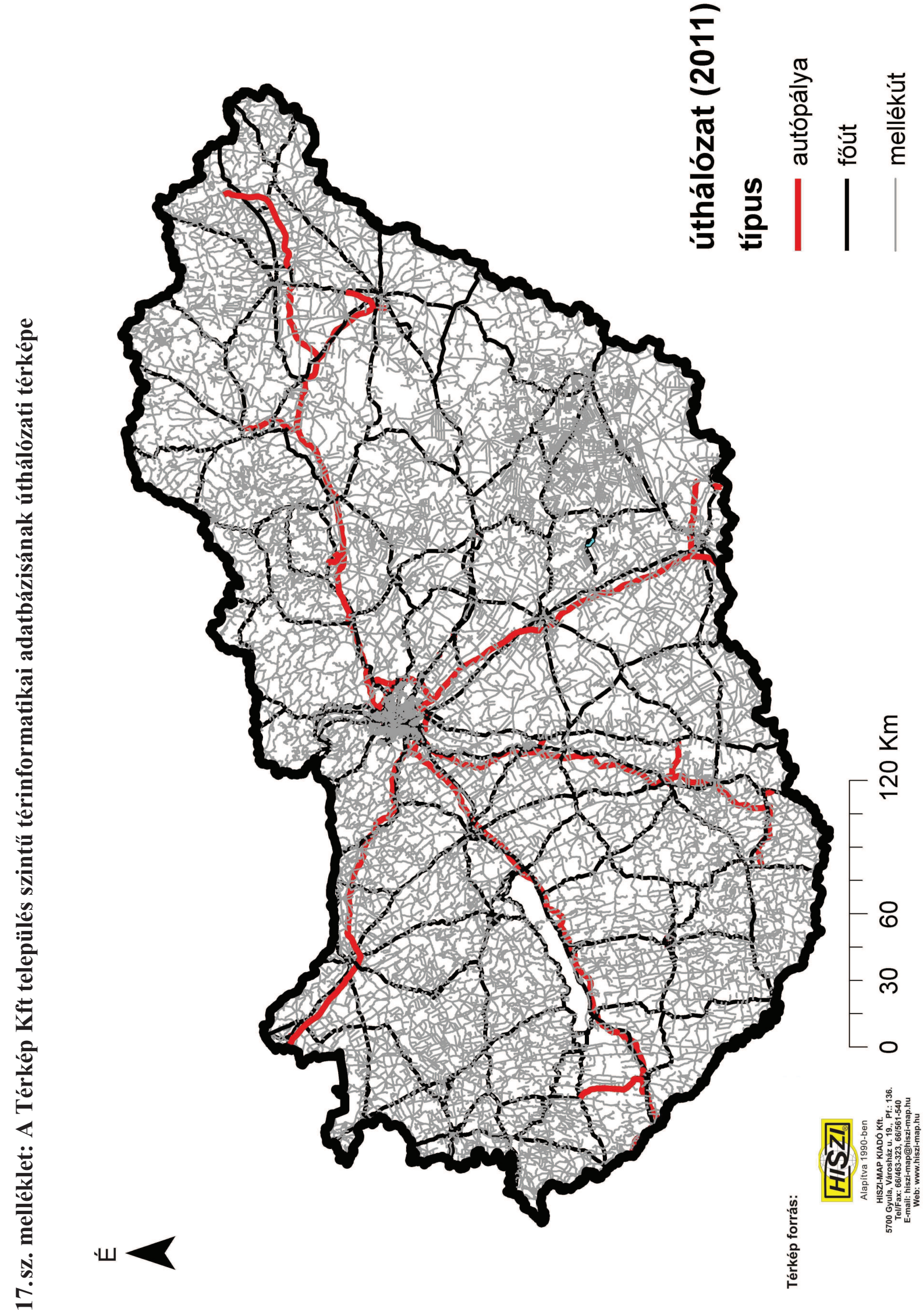


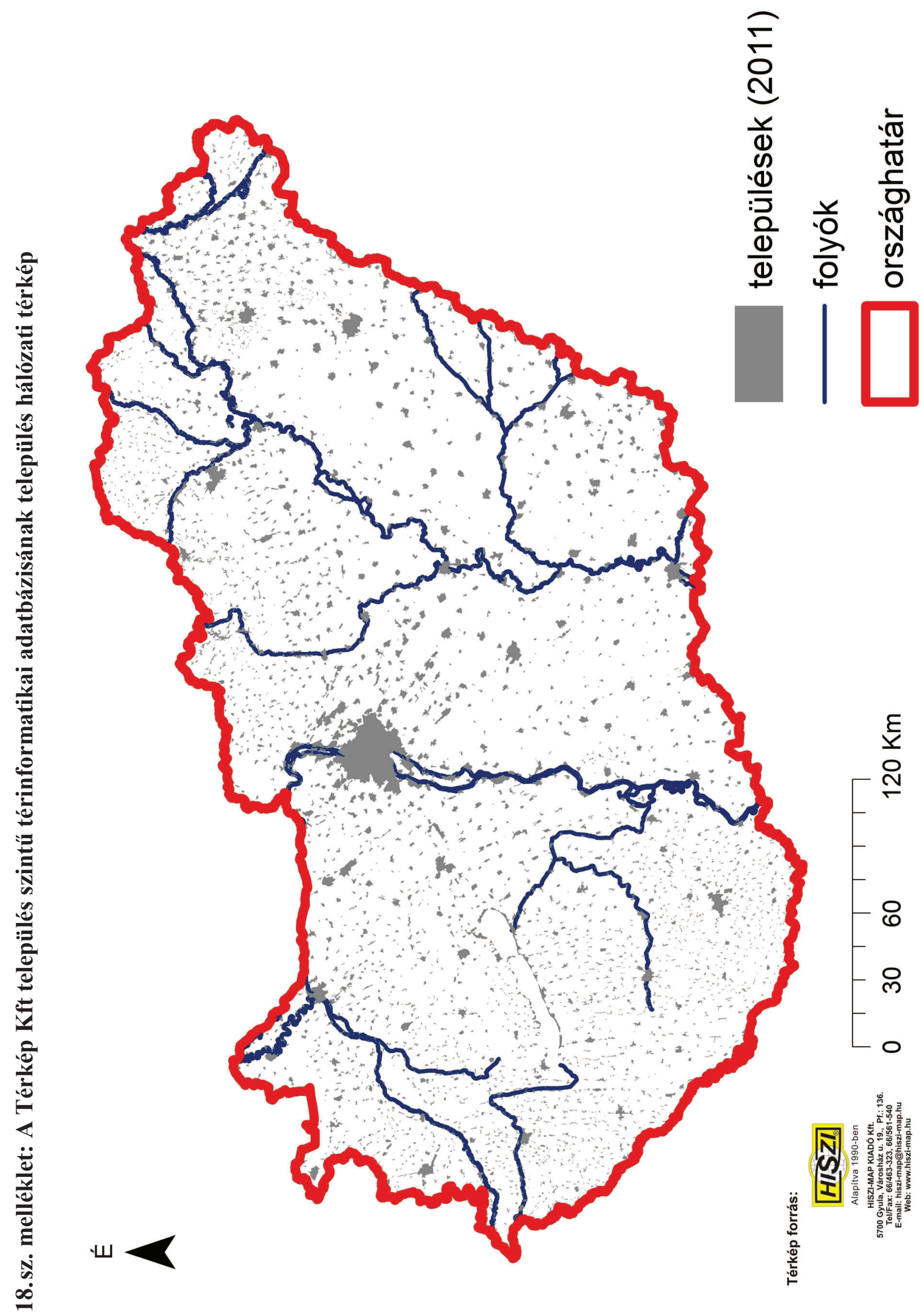




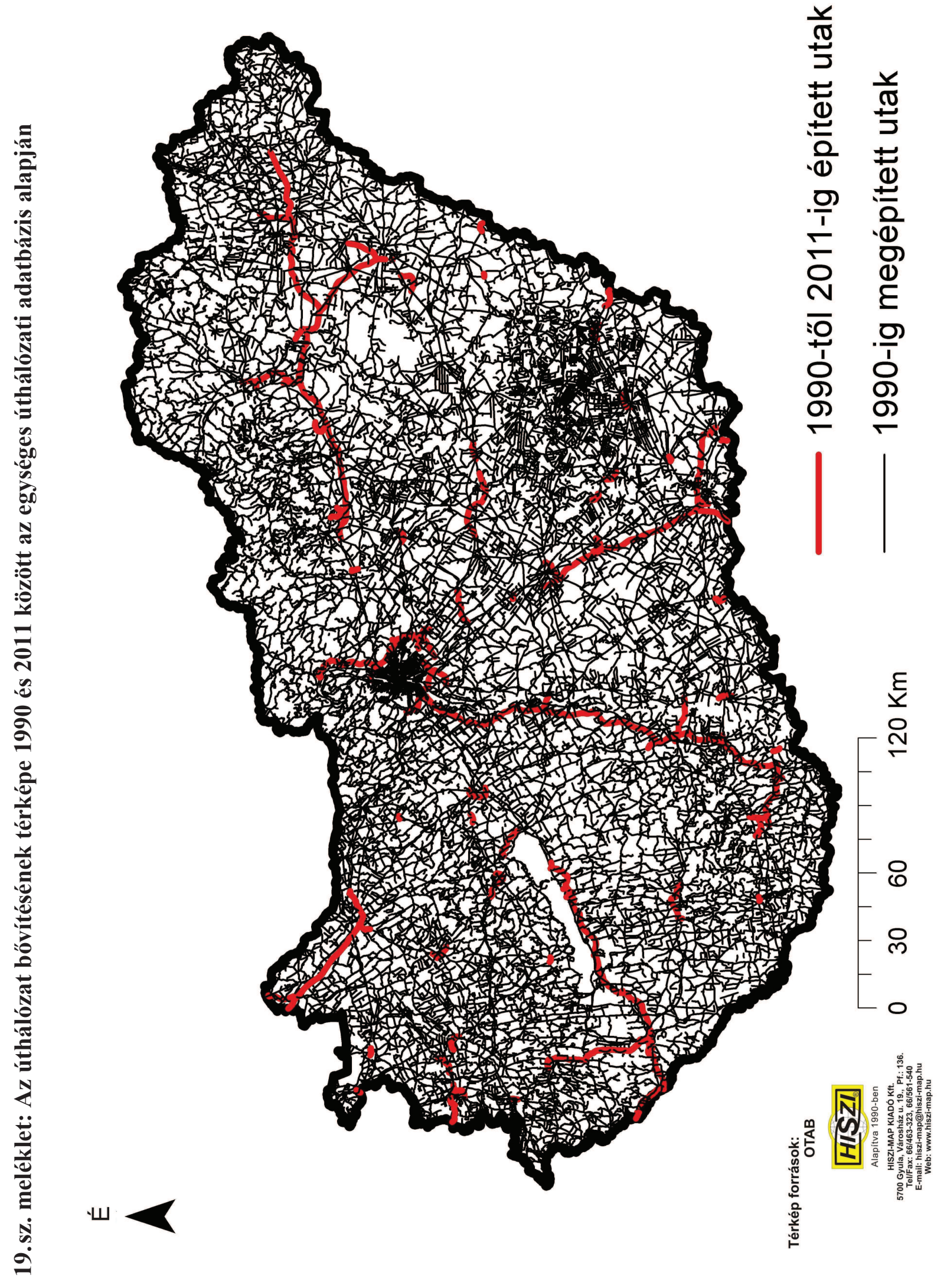




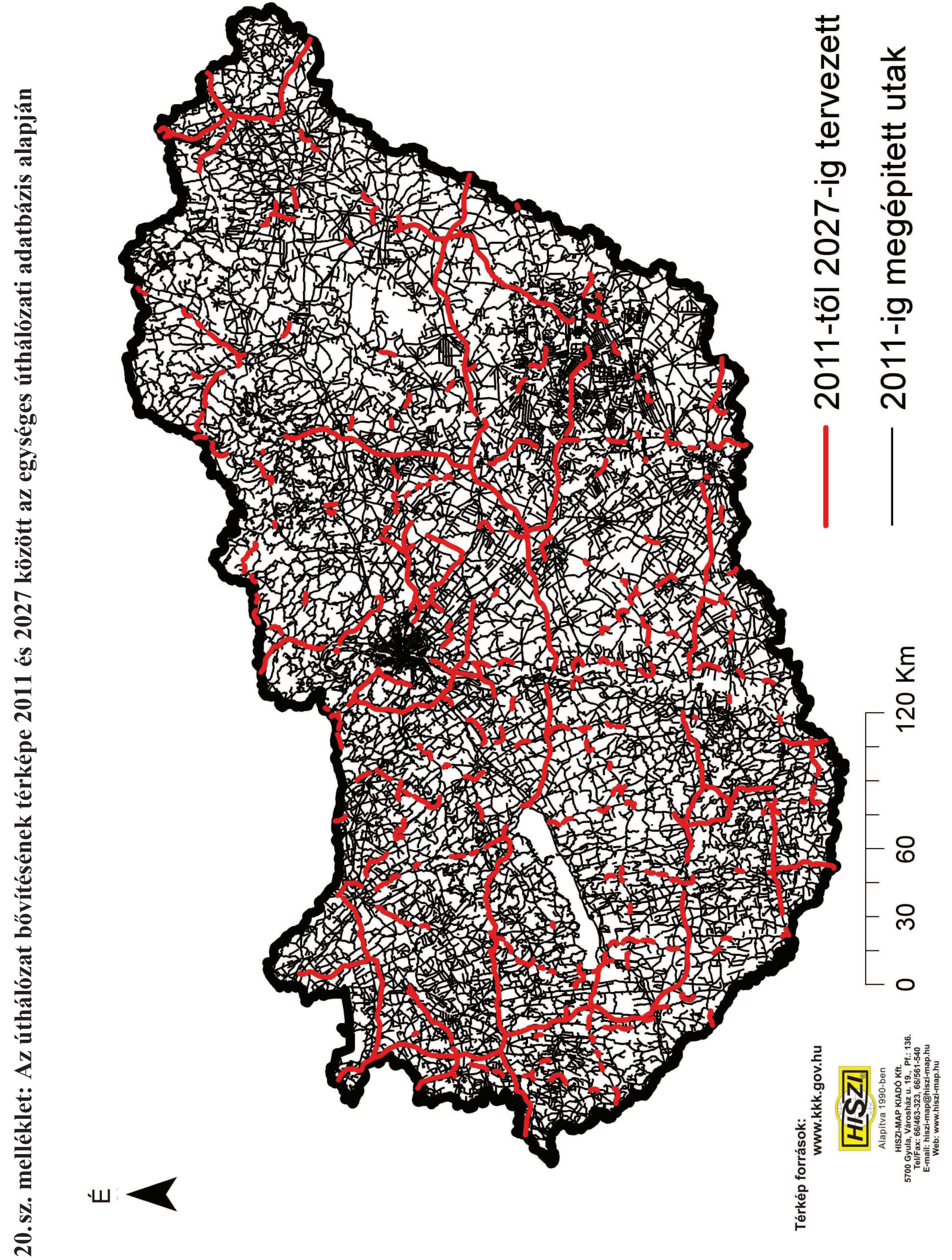

